\title{
BASELINE RISK ASSESSMENT OF Ground WATER CONTAMINATION AT THE URANIUM Mill TAILINGS SITE Near falls City, Texas
}

\author{
FEG \\ DEC OS 1994 \\ OSTI
}

\section{September 1994}

\section{DISCLAIMER}

This report was prepared as an account of work sponsored by an agency of the United States Government. Neither the United States Government nor any agency thereof, nor any of their employees, makes any warranty, express or implied, or assumes any legal liability or responsibility for the accuracy, completeness, or usefulness of any information, apparatus, product, or process disclosed, or represents that its use would not infringe privately owned rights. Reference herein to any specific commercial product, process, or service by trade name, trademark, manufacturer, or otherwise does not necessarily constitute or imply its endorsement, recommendation, or favoring by the United States Government or any agency thereof. The views and opinions of authors expressed herein do not necessarily state or reflect those of the United States Government or any agency thereof. 


\section{DISCLAIMER}

\section{Portions of this document may be illegible in electronic image products. Images are produced from the best available original document.}


INTENDED FOR PUBLIC RELEASE

This report has been reproduced from the best available copy. Available in paper copy and microfiche.

Number of pages in this report: 166

DOE and DOE contractors can obtain copies of this report from:

Office of Scientific and Technical Information

P.O. Box 62

Oak Ridge, TN 37831

(615) 576-8401

This report is publicly available from:

National Technical Information Service

Department of Commerce

5285 Port Royal Road

Springfield, VA 22161

(703) $487-4650$ 
BASELINE RISK ASSESSMENT OF GROUND WATER CONTAMINATION AT THE URANIUM MILL TAILINGS SITE NEAR FALLS CITY, TEXAS

September 1994

Prepared for

U.S. Department of Energy UMTRA Project Office

Albuquerque, New Mexico

Prepared by

Jacobs Engineering Group Inc.

Albuquerque, New Mexico 


\section{CITIZEN'S SUMMARY}

This baseline risk assessment of ground water contamination at the uranium mill tailings site near Falls City, Texas, evaluates potential impact to public health and the environment resulting from ground water contamination at the former Susquehanna Western, Inc. (SWI), uranium mill processing site. This document fulfills the following objectives: determine if the site presents immediate or potential future health risks, determine the need for interim institutional controls, serve as a key input to project planning and prioritization, and recommend future data collection efforts to more fully characterize risk. The Uranium Mill Tailings Remedial Action (UMTRA) Project has begun its evaluation of ground water contamination at the Falls City site. This risk assessment is one of the first documents specific to this site for the Ground Water Project.

Shallow ground water beneath the Falls City site is contained in three water bearing units: the Deweesville Member (0 to 50 feet [ft] [0 to 15 meters $(\mathrm{m})$ ] below land surface), the Conquista Member $(0$ to $90 \mathrm{ft}[0$ to $27 \mathrm{~m}$ ] below land surface), and the Dilworth Member ( 30 to $150 \mathrm{ft}$ [ 9 to $46 \mathrm{~m}$ ] below land surface). Natural water quality in these formations in the site vicinity is extremely variable and generally of poor quality. The presence of uranium ore bodies and the exploratory and mining activities associated with their development makes characterization of the premilling water quality very difficult. Uranium ore deposits were discovered in late 1955 and mined during 1959 and 1960. Open pit mining occurred at the former locations of piles $3,4,5$, and 6 . Water from these formations is not a current or potential source of drinking water. Ground water from the uppermost aquifer (Deweesville/Conquista Members and the Dilworth Member) contains widespread ambient contamination resulting from naturally occurring conditions and from the effects of human activity not related to uranium milling operations.

Ground water quality beneath the Falls City site has been further degraded by the mill processing activities. The former SWI uranium mill operated between 1961 and 1973 . The tailings and other contaminated materials were placed in a disposal cell on the site in 1994 by the UMTRA Project. The constructed cell is designed to stabilize and control the tailings and other residual radioactive materials for 1000 years to the extent reasonably achievable.

There are no known livestock, domestic, or drinking water wells in the contaminated ground water of the Deweesville/Conquista aquifer. The extent of contamination in this aquifer needs to be further defined, although levels of sulfate, manganese, and uranium are known to be highly elevated. However, these contaminants are detected in the water at levels high enough to be associated with adverse health effects, if consumed. The water quality is sufficiently poor in this aquifer that it has no historic or current use as a drinking water supply.

There is no known current use of the Dilworth aquifer ground water as a drinking water supply within a 2-mile (3-kilometer) radius of the site. Water from this aquifer historically has been considered to be of poor quality. Water from the Dilworth aquifer has been used to water livestock and gardens in the site vicinity. Even though access to the most contaminated portions of the aquifer is restricted by the site fence and the water 
historically has not been used, this risk assessment evaluates potential current and future use of the Dilworth aquifer at the site. Potential exposure to surface water from Scared Dog and Tordilla Creeks and from ponds are also evaluated as they may also be sources of exposure for livestock and wildlife.

This risk assessment follows the approach outlined by the U.S. Environmental Protection Agency (EPA). The first step is to evaluate ground water data collected from monitor wells at or near the site. Evaluation of these data show the main contaminants in the Dilworth ground water are cadmium, cobalt, fluoride, iron, nickel, sulfate, and uranium. The data also show high levels of arsenic and manganese occur naturally in some areas. These constituents typically are associated with the natural uranium ore deposits found in the Falls City site area. The next step in the risk assessment process is to estimate how much of these contaminants people would be exposed to if a drinking water well were installed in the contaminated ground water. Then the amount of contaminants that might be ingested is compared to the toxic effects these levels might cause in humans.

Three ways the contaminants could enter the human body were evaluated: drinking the water, eating meat from livestock that drank the water, or drinking milk from livestock that drank the water. If ground water from the Dilworth aquifer at the western region of the site were directly consumed by humans, the additional cancer risk would be 1 in 1000 over a lifetime. However, such consumption is unlikely, due to the inaccessibility of water, the unpalatable taste and odor of the water, the historical knowledge of the poor water quality, and the presence of better quality water from other sources.

In addition, the levels of manganese and arsenic detected in the natural ground water unaffected by the former mill site could lead to an increased risk of developing nervous system disorders and/or skin cancer. These naturally occurring metals limit the potential use of ground water for drinking water. The U.S. Nuclear Regulatory Commission and the state of Texas concur that the naturally occurring water in these aquifers is Class III (limited use). The amount of treatment required to make the water usable for human consumption is excessive compared to that normally employed in this part of Texas.

The potential health effects on livestock if ground water from the Dilworth Formation or the remaining ponds near the site were used to water cattle were also evaluated. The evaluation showed that livestock probably would not suffer adverse health effects from either source. Based on this evaluation, no adverse health effects would be expected in humans eating the meat or drinking the milk from livestock watered from these sources.

The Falls City site will be further evaluated under the UMTRA Ground Water Project. This will include continued evaluation of the Deweesville/Conquista and Dilworth ground water to better understand the nature and extent of contamination from the milling activities. Based on the results of these additional activities, an approach will be developed to address water contamination. This approach will be presented in an environmental assessment report and will include public and state government involvement. Use of water in the vicinity of the site will continue to be monitored. In the interim, the effectiveness of restricted access to contaminated ground water will be evaluated. 
TABLE OF CONTENTS

Section

Page

CITIZEN'S SUMMARY $\ldots \ldots \ldots \ldots \ldots \ldots \ldots \ldots \ldots \ldots \ldots \ldots \ldots \ldots$

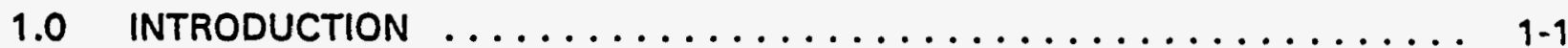

2.0 SITE DESCRIPTION .......................... $2-1$

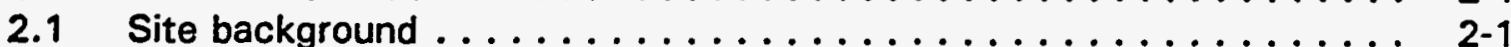

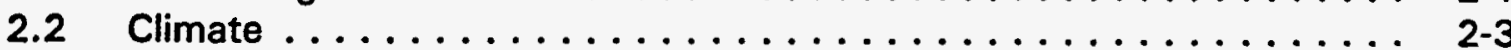

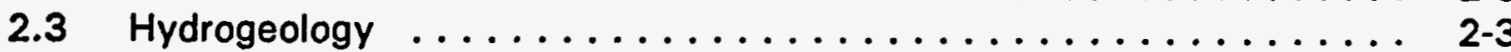

2.3.1 Deweesville/Conquista aquifer ................ 2-3

2.3.2 Dilworth aquifer ..................... 2-6

2.3.3 Upper Manning Clay Formation . . . . . . . . . . . . . 2- 2-9

2.3.4 Yegua and Carrizo aquifers ................. 2-9

2.4 Surface water $\ldots \ldots \ldots \ldots \ldots \ldots \ldots \ldots \ldots \ldots \ldots \ldots \ldots \ldots \ldots$

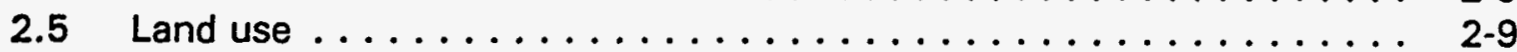

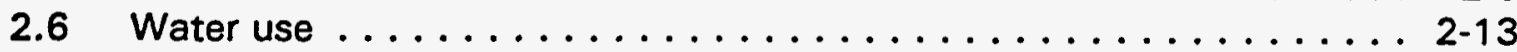

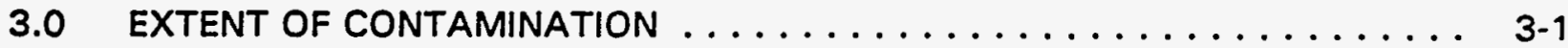

3.1 Background ground water quality ................ 3-1

3.1.1 Deweesville/Conquista ..................... 3-5

3.1 .2 Dilworth ........................ 3-13

3.2 Magnitude of site-related ground water contamination . . . . . . . . 3-24

3.2.1 Deweesville/Conquista .................. 3-24

3.2 .2 Dilworth ......................... 3-26

3.3 Contaminants of potential concern . . . . . . . . . . . . 3-27

3.4 Contaminant fate and transport . . . . . . . . . . . . . 3-28

4.0 EXPOSURE ASSESSMENT $\ldots \ldots \ldots \ldots \ldots \ldots \ldots \ldots \ldots \ldots \ldots \ldots \ldots$

4.1 Potentially exposed population . . . . . . . . . . . . . . . 4-1

4.2 Exposure pathways ...................... 4-1

4.3 Exposure concentrations ...................... 4-2

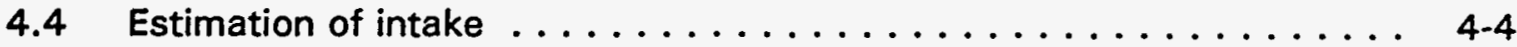

4.5 Exposure assessment uncertainties ................ 4-12

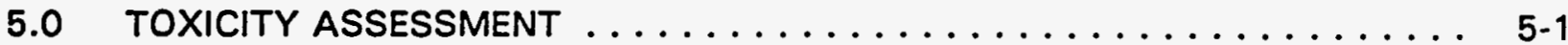

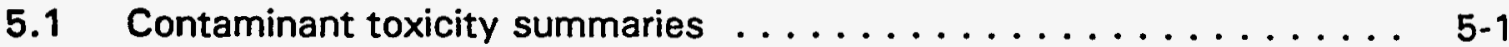

5.1 .1 Cadmium ........................ $5-1$

5.1 .2 Cobalt ......................... $5-4$

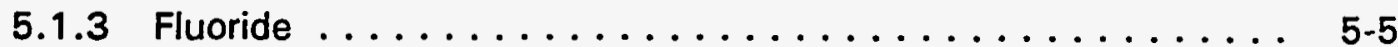

5.1 .4 Iron ........................ 5-11

5.1 .5 Nickel ........................ 5-13

5.1 .6 Sulfate ......................... 5-16

5.1 .7 Uranium ......................... 5-20

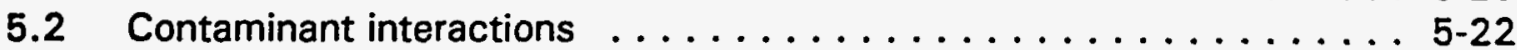

5.3 Contaminant risk factors . . . . . . . . . . . . . . . . $5-25$ 


\section{TABLE OF CONTENTS (Concluded)}

Section

Page

6.0 HUMAN HEALTH RISK EVALUATION $\ldots \ldots \ldots \ldots \ldots \ldots \ldots \ldots \ldots$

6.1 Potential noncarcinogenic health effects ................ 6-1

6.1.1 Deweesville/Conquista ground water-potential future use .... 6-1

6.1.2 Potential current and future use of the Dilworth ground water ............................ 6-4

6.2 Potential carcinogenic health effects $\ldots \ldots \ldots \ldots \ldots \ldots \ldots \ldots \ldots$

6.2.1 Deweesville/Conquista potential future use ........... 6-13

6.2.2 Dilworth ground water current and potential future use . . . . . 6-13

6.3 Limitations of risk evaluation ................... 6-13

7.0 LIVESTOCK AND ENVIRONMENTAL EVALUATION ............ $7-1$

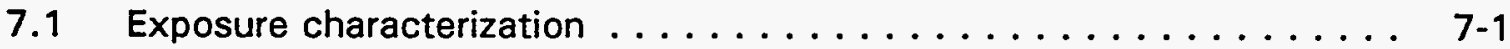

7.2 Ecological receptors ...................... 7.4

7.2.1 Plant communities and wildlife ............... 7-4

7.2.2 Threatened and endangered species ............ $7-5$

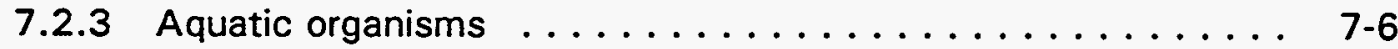

7.3 Contaminants of ecological concern ............... 7-6

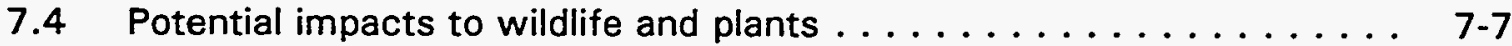

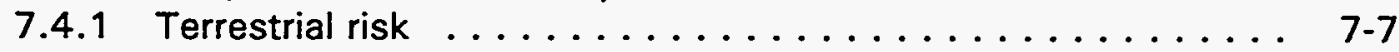

7.4 .2 Aquatic risk ...................... $7-13$

7.5 Potential impacts to livestock .................. 7-21

7.6 Limitations of the ecological risk assessment $\ldots \ldots \ldots \ldots \ldots \ldots \ldots$. . . . . .

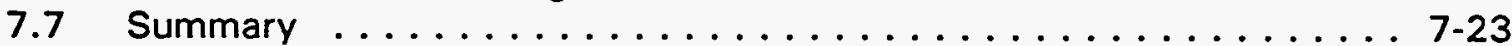

8.0 INTERPRETATION AND RECOMMENDATIONS $\ldots \ldots \ldots \ldots \ldots \ldots \ldots$

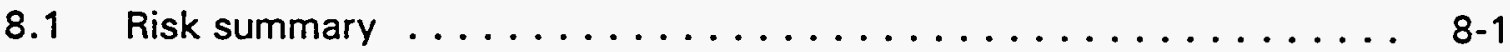

8.2 Limitations of this risk assessment . . . . . . . . . . . . . . $8-2$

8.3 Ground water criteria $\ldots \ldots \ldots \ldots \ldots \ldots \ldots \ldots \ldots \ldots \ldots$

8.4 Risk mitigation measures $\ldots \ldots \ldots \ldots \ldots \ldots \ldots \ldots \ldots \ldots$

8.5 Recommendations ....................... 8-7

9.0 LIST OF CONTRIBUTORS $\ldots \ldots \ldots \ldots \ldots \ldots \ldots \ldots \ldots \ldots \ldots$

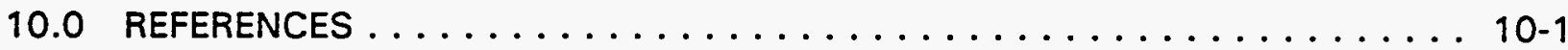




\section{LIST OF FIGURES}

2.1 Location of the Falls City, Texas, site $\ldots \ldots \ldots \ldots \ldots \ldots \ldots \ldots$

2.2 Geologic cross section A'-A', Falls City, Texas, site . . . . . . . . . . . . . . 2-4

2.3 Surface geology and cross section location, Falls City, Texas, site . . . . . . 2-5

2.4 Potentiometric surface of the Deweesville/Conquista aquifer, Falls City, Texas, site . . . . . . . . . . . . . . . . . . . . . . . 2-7

2.5 Potentiometric surface of the Dilworth aquifer, Falls City, Texas, site . . . . 2-8

2.6 Land ownership and water use locations, Falls City, Texas, site . . . . . . . 2-12

3.1 Locations of monitor wells, Falls City, Texas, site . . . . . . . . . . . . . 3-2

3.2 Locations of surface uranium mines and mills near Falls City, Texas, site .............................. 3-3

3.3 Identified ore deposits and mineralization in Deweesville/Conquista Formation, Falls City, Texas, site . . . . . . . . . . . . . . . .

3.4 Locations of the Dilworth background wells and the Deweesville/Conquista Conoco 600 series wells, Falls City, Texas, site . . . . . . . . . . . . .

3.5 Trilinear plot of data from the Deweesville/Conquista monitor wells 667 , 668 , and selected Hobson Deweesville monitor wells, Falls City,

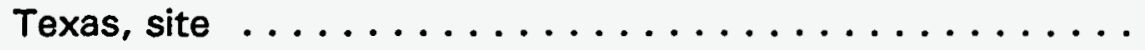

3.6 Tritinear plot of the Dilworth background ground water and the Deweesville/Conquista reference water, Falls City, Texas, site . . . . . . . . 3-14

3.7 Approximate distribution of tailings-contaminated ground water in Deweesville/Conquista aquifer, Falls City, Texas, site . . . . . . . . . 3-25

4.1 Conceptual model for the Dilworth ground water potential use pathways, Falls City, Texas, site . . . . . . . . . . . . . . . . . . . .

5.1 Cadmium toxicity ranges $\ldots \ldots \ldots \ldots \ldots \ldots \ldots \ldots \ldots \ldots \ldots \ldots$

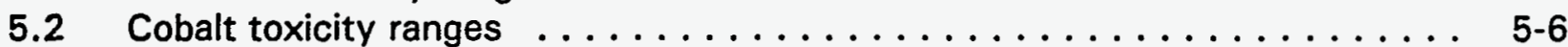

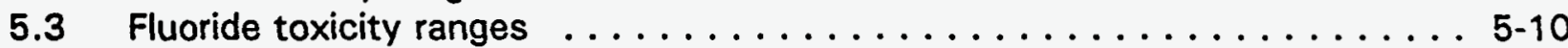

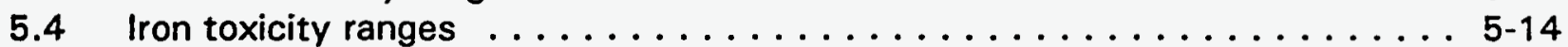

5.5 Nickel toxicity ranges . . . . . . . . . . . . . . . . . . 5-17

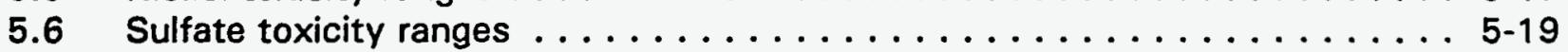

5.7 Half-lives and emissions from decay chain of uranium-238 . . . . . . . 5-21

5.8 Uranium toxicity ranges $\ldots \ldots \ldots \ldots \ldots \ldots \ldots \ldots \ldots \ldots \ldots \ldots \ldots$

6.1 Health effects of estimated sulfate exposure from the Dilworth ground water, Falls City, Texas, site . . . . . . . . . . . . . . . . . .

6.2 Health effects of estimated iron exposure from the Dilworth ground water, Falls City, Texas, site . . . . . . . . . . . . . . . .

6.3 Health effects of estimated cadmium exposure from the Dilworth ground water, Falls City, Texas, site . . . . . . . . . . . . . . . . . .

6.4 Health effects of estimated uranium exposure from the Dilworth ground water, Falls City, Texas, site ..................... 


\section{LIST OF FIGURES (Concluded)}

\section{Figure}

Page

6.5 Health effects of estimated fluoride exposure from the Dilworth ground water, Falls City, Texas, site . . . . . . . . . . . . . . . . . 6-10

6.6 Health effects of estimated cobalt exposure from the Dilworth ground water, Falls City, Texas, site . . . . . . . . . . . . . . . . . 6-11

6.7 Health effects of estimated nickel exposure from the Dilworth ground water, Falls City, Texas, site . . . . . . . . . . . . . . . . . 6-12

7.1 Surface water, sediment, fish, and vegetation sampling locations, Falls City, Texas, site .......................... 7-3 


\section{LIST OF TABLES}

Table

Page

2.1 Land use near the Falls City, Texas, site, $1993 \ldots \ldots \ldots \ldots \ldots$. . . . . . . . . 2-10

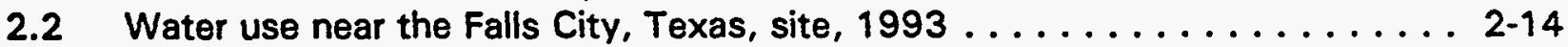

3.1 Water quality in the Deweesville/Conquista aquifer at the Falls City,

Texas, site ................................

3.2 Well completion and sampling, Dilworth aquifer background wells and contaminated wells .............................. 3-15

3.3 Statistical summary of the Dilworth ground water quality data at the Falls City UMTRA site, Falls City, Texas, filtered samples, 1989-1992 . . . 3-16

3.4 Contaminants of potential concern for the Dilworth aquifer, Falls City,

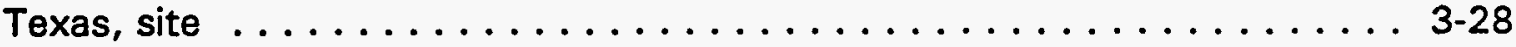

3.5 Chemical speciation .......................... 3-30

4.1 Exposure concentrations for the Dilworth ground water potential use,

Falls City, Texas, site . . . . . . . . . . . . . . . . . . . . . . 4-4

4.2 Quantitatively evaluated exposure routes . . . . . . . . . . . . . . . . 4-5

4.3 Exposure dose calculations for ingestion of Dilworth ground water and dermal contact, Falls City, Texas, site . . . . . . . . . . . . . . 4-6

4.4 Exposure dose calculations for beef and milk consumption from cattle ingesting Dilworth ground water, Falls City, Texas, site . . . . . . . . . 4 4-9

5.1 Toxicity values: potential noncarcinogenic effects $\ldots \ldots \ldots \ldots \ldots \ldots$

5.2 Toxicity values: potential carcinogenic effects . . . . . . . . . . . . . 5-27

6.1 Carcinogenic risk for the Dilworth ground water potential ingestion pathway at the Falls City, Texas, site $\ldots \ldots \ldots \ldots \ldots \ldots \ldots \ldots \ldots \ldots \ldots$

6.2 Carcinogenic risk for the ingestion of beef and milk from cattle ingesting Dilworth ground water, Falls City, Texas, site . . . . . . . . . 6-15

7.1 Occurrence of constituents detected in vegetation collected from water bodies in the site vicinity, Falls City, Texas, site . . . . . . . . . . . 7-8

7.2 Comparison of selected constituents in Deweesville/Conquista ground water with available water quality values, Falls City, Texas, site . . . . . . 7-10

7.3 Comparison of contaminants of potential concern in Dilworth ground water with available water quality values, Falls City, Texas, site . . . . . . . 7-11

7.4 Comparison of constituents detected in surface water from Tordilla Creek and Scared Dog Creek with available surface water quality values, Falls City, Texas, site . . . . . . . . . . . . . . . . . . . . 7-15

7.5 Comparison of constituents detected in surface water from ponds located in the site vicinity with available surface water quality values,

Falls City, Texas, site . . . . . . . . . . . . . . . . . . . . . . 7-16

7.6 Comparison of constituents detected in sediment from surface water bodies in the site vicinity with sediment quality values, Falls City, Texas, site . . . . 7-19 


\section{LIST OF TABLES (Concluded)}

Table

Page

7.7 Occurrence of constituents detected in fish collected from the pond east of former pile 3, Falls City, Texas, site . . . . . . . . . . . . . 7-20

8.1 Concentrations limits of constituents in the Dilworth aquifer . . . . . . 8-5 


\section{LIST OF ACRONYMS AND ABBREVIATIONS}

\begin{tabular}{|c|c|}
\hline Acronym & Definition \\
\hline ac & acre \\
\hline ACL & alternate concentration limit \\
\hline ANOVA & analysis of variance \\
\hline${ }^{B C F}$ & bioconcentration factors \\
\hline & degrees Celsius \\
\hline $\mathrm{cm}$ & centimeter \\
\hline DHHS & U.S. Department of Health and Human Servies \\
\hline DOE & U.S. Department of Energy \\
\hline DMA & dimethylarsenic acid \\
\hline EPA & U.S. Environmental Protection Agency \\
\hline ER-L & effects range-low \\
\hline ER-M & effects range-median \\
\hline $\begin{array}{l}\text { ESADDI } \\
{ }^{\circ} \mathrm{F}\end{array}$ & $\begin{array}{l}\text { estimated safe and adequate daily dietary intake } \\
\text { degrees Fahrenheit }\end{array}$ \\
\hline FM & Farm-to-Market Road \\
\hline $\mathrm{ft}$ & feet \\
\hline FWOC & Federal Water Quality Criteria \\
\hline ha & hectare \\
\hline HEAST & Health Effects Assessment Summary Tables \\
\hline IRIS & Integrated Risk Information System \\
\hline $\mathrm{kg}$ & kilogram \\
\hline $\mathrm{km}$ & kilometer \\
\hline L & liter \\
\hline $\mathrm{L} / \mathrm{kg}$ & liters per kilogram \\
\hline LOAEL & lowest-observed-adverse-effect level \\
\hline m & meter \\
\hline $\mathrm{m}^{2}$ & square meter \\
\hline$m^{3}$ & cubic meter \\
\hline MCL & maximum concentration limit \\
\hline$\mu g$ & microgram \\
\hline$\mu \mathrm{g} / \mathrm{g}$ & microgram per gram \\
\hline$\mu \mathrm{g} / \mathrm{kg}$ & micrograms per kilogram \\
\hline$\mu \mathrm{g} / \mathrm{L}$ & micrograms per liter \\
\hline$\mu \mathrm{mos} / \mathrm{cm}$ & micromho per centimeter \\
\hline $\mathrm{mg}$ & milligram \\
\hline $\mathrm{mg} / \mathrm{g}$ & milligrams per gram \\
\hline $\mathrm{mg} / \mathrm{kg}$ & milligrams per kilogram \\
\hline $\mathrm{mg} / \mathrm{kg}$-day & milligrams per kilogram per day \\
\hline $\mathrm{mg} / \mathrm{L}$ & milligrams per liter \\
\hline $\mathrm{mi}$ & mile \\
\hline $\mathrm{mL}$ & milliliter \\
\hline MSL & mean sea level \\
\hline NCP & National Contingency Plan \\
\hline
\end{tabular}




\section{LIST OF ACRONYMS AND ABBREVIATIONS (Concluded)}

Acronym

NEPA
NOAA
NOAEL
PEIS
pCi/L
ppm
RAP
RDA
RfD
SEI
SOC
SWI
TDS
TWC
UCL
UMTRA
UMTRCA
U ${ }_{3}{ }_{8}$
Yd

\section{Definition}

National Environmental Policy Act

National Oceanic and Atmospheric Administration

no-observed-adverse-effect level

programmatic environmental impact statement

picocuries per liter

parts per million

remedial action plan

recommended daily allowance

reference dose

Solution Engineering, Inc.

sediment quality criteria

Susquehanna Western, Inc.

total dissolved solids

Texas Water Commission

upper confidence limit

Uranium Mill Tailings Remedial Action

Uranium Mill Tailings Radiation Control Act

uranium oxide

cubic yard 


\subsection{INTRODUCTION}

The purpose of this baseline risk assessment is to determine whether ground water contamination at the Falls City, Texas, the former Susquehanna Western, Inc. (SWI) uranium mill tailings site could adversely affect public health or the environment. The Falls City site is one of 24 abandoned uranium mill tailings sites that are undergoing remediation in accordance with the requirements of the Uranium Mill Tailings Radiation Control Act (UMTRCA) of 1978 (42 USC $\$ 7901$ et seq.), (Public Law 95-604), under the direction of the U.S. Department of Energy (DOE) Uranium Mill Tailings Remedial Action (UMTRA) Project.

The first phase of the UMTRA Project is to stabilize the tailings in a disposal cell to minimize radon emissions and further contamination of ground water. At Falls City, the first phase of the UMTRA Project was completed in 1994, with stabilization of the tailings in a disposal cell at the former uranium mill site.

The second phase of the UMTRA Project evaluates ground water contamination at the uranium processing sites, determines whether any action is necessary, and implements action, as needed. The 1988 amendments to the UMTRCA authorize the DOE to perform ground water restoration activities.

The draft programmatic environmental impact statement (PEIS) for the UMTRA Ground Water Project (DOE, 1994) describes the strategy to evaluate and methods to clean up contaminated ground water at the UMTRA Project sites. This baseline risk assessment is one of the site-specific documents prepared to evaluate potential health and environmental risks and provide information to assist in determining what remedial action is necessary. Following the PEIS and this risk assessment, a site-specific environmental assessment or an environmental impact statement will be prepared to evaluate and select a ground water compliance strategy.

This risk assessment is a baseline assessment in that it describes preremediation ground water conditions at the site, based on available ground water data. This document evaluates the potential for imminent human health or environmental risks that may need attention before the site is fully characterized.

The evaluation is based on available ground water data from the most contaminated wells at the processing site. The evaluation also considers the extreme variability in background water quality caused by natural mineral deposits and mining activities in the mill site area. Only the major exposure pathways have been thoroughly examined. If future data collection, decisions, or actions at this site cause conditions to change, other pathways will be evaluated.

This risk assessment follows the basic framework outlined by the U.S. Environmental Protection Agency (EPA) (1989a) for evaluating hazardous waste sites to assess potential 
health and environmental impacts. The risk assessment process consists of the following steps:

- Data evaluation.

- Combining data from various site investigations.

- Comparing sample results with background and tailings source data.

- Selecting chemical data for use in the risk assessment.

- Exposure assessment.

- Characterizing the exposure setting.

- Identifying exposure pathways.

- Quantifying exposure.

- Toxicity assessment.

- Identifying toxicity values.

- Evaluating noncarcinogenic effects.

- Evaluating carcinogenic effects from radionuclides and chemical carcinogens.

- Public health risk characterization.

- Comparing toxicity ranges to predicted exposure ranges.

- Combining risks across exposure pathways and multiple contaminants.

- Characterizing uncertainties.

- Environmental risk.

- Characterizing potential biota exposure pathways.

- Identifying potential ecological receptors.

- Evaluating environmental risk qualitatively.

This framework is incorporated in the methodology used to evaluate current human health risk at UMTRA Project sites and to estimate risks from potential future use of contaminated ground water or surface water near the former uranium processing site. A report describing this methodology is in preparation. Although the methodology report discusses the probabilistic approach used at most UMTRA sites, sufficient data were not available at the Falls City site to allow generation of distributions of contaminant concentrations and intakes. As discussed in Section 4.0, point concentrations are used to estimate contaminant intakes. 


\subsection{SITE DESCRIPTION}

The Falls City site is in Karnes County, Texas, approximately 8 miles (mi) (13 kilometers [km]) southwest of the town of Falls City and about $40 \mathrm{mi}(65 \mathrm{~km})$ southeast of San Antonio, Texas (Figure 2.1). Before surface remedial action, the tailings site consisted of two parcels. Parcel A consisted of the mill site, one mill building, five tailings piles, and one tailings pond south of Farm-to-Market Road 1344 (FM 1344) and west of FM 791. A sixth tailings pile (designated Parcel B) existed north of FM 1344 and west of FM 791.

\section{$2.1 \quad$ SITE BACKGROUND}

In 1954, the first shallow uranium ore deposits were discovered in western Karnes County, Texas. These discoveries of uranium, the first in the Gulf Coastal Plain, led to extensive exploratory drilling and mining. SWI built and operated a uranium mill at the Falls City site from April 1961 until August 1973. The mill used a sulfuric acid leach-countercurrent, decantation-solvent extraction process to treat approximately 2.5 million tons ( 2.3 million metric tons) of ore averaging 0.16 percent uranium oxide $\left(\mathrm{U}_{3} \mathrm{O}_{8}\right)$. More than 700 tons (600 metric tons) of $\mathrm{U}_{3} \mathrm{O}_{8}$ concentrate ("yellow cake") were sold to the Atomic Energy Commission while the mill was in operation.

Waste tailings and processing solutions from the SWI milling operation were impounded in seven separate ponds, four of which had been open pit mines excavated into the ore-bearing sandstone. The tailings ponds were 30 to 35 feet ( $\mathrm{ft}$ ) (9 to 11 meters [m]) deep and unlined, except for naturally clayey foundation soils and sediments.

In 1975, SWI sold the mill site and residual tailings piles to Solution Engineering, Inc. (SEI), and its partner, Basic Resources, Inc. From late 1978 to early 1982, SEl conducted secondary solution mining of uranium from four of the piles. This operation included a system of shallow injection/recovery wells and an ion exchange bed to recover uranium and molybdenum from solution. The uranium leaching agent was acid water from tailings pond 7. Residual process waters were pumped back to this pond. All pond waters were evaporated except pond 6 , which was likely to be recharged by natural seepage.

All tailings and contaminated materials have been consolidated and stabilized into a disposal cell in the location of former piles 1,2 , and 7 . The contaminated materials are covered with a 36-inch (92-centimeter [cm])-thick radon barrier to inhibit radon emanation. A 6 -inch $(15-\mathrm{cm})$-thick bedding layer above the radon barrier is overlain by a 30-inch $(80-\mathrm{cm})$-thick rooting layer, with 6 inches $(15 \mathrm{~cm})$ of top soil mixed with gravel to establish a vegetative topslope. The sideslopes are covered with riprap. The disposal cell covers approximately 130 acres (ac) (50 hectares [ha]).

The area around the designated site was contoured to divert runoff from upland drainages away from the disposal cell. The excavated tailings piles, pond 6 , and 


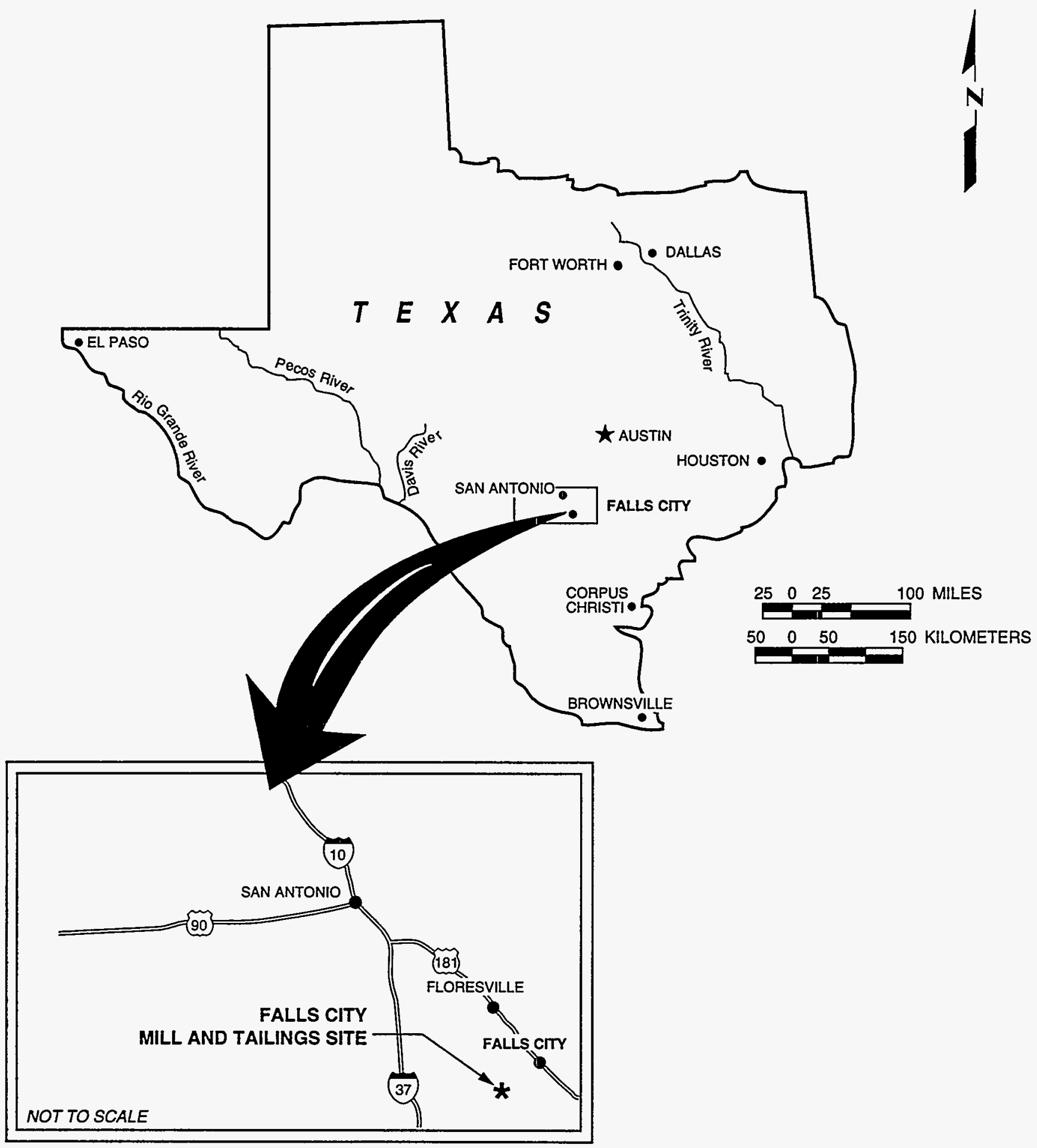

\section{LEGEND}

(37) INTERSTATE HIGHWAY

(181) U.S. HIGHWAY

FIGURE 2.1

LOCATION OF THE FALLS CITY, TEXAS, SITE 
former mill areas were restored with uncontaminated fill. Disturbed areas were graded to promote drainage and revegetation. The final restricted area of approximately $290 \mathrm{ac}(120 \mathrm{ha})$ is enclosed by a fence. The remainder of the designated site will be released for any use consistent with existing land use controls, after all remedial action is complete.

\subsection{CLIMATE}

Local weather data for the Falls City site were obtained from the Panna Maria Uranium Operations (Chevron Resources), $15 \mathrm{mi}(24 \mathrm{~km}$ ) east of the site and from the San Antonio International Airport about $40 \mathrm{mi}(65 \mathrm{~km})$ northwest of the tailings site. Typical summer temperatures range from 70 to 90 degrees Fahrenheit $\left({ }^{\circ} \mathrm{F}\right)\left(20\right.$ to 32 degrees Celsius [ $\left.\left.{ }^{\circ} \mathrm{C}\right]\right)$. Typical winter temperatures range from 30 to $60^{\circ} \mathrm{F}\left(0\right.$ to $\left.10^{\circ} \mathrm{C}\right)(D O E, 1992)$. Data from the Panna Maria site indicate the average annual rainfall is 30 inches $(80 \mathrm{~cm})$ per year.

\subsection{HYDROGEOLOGY}

The Falls City site is underlain by sedimentary rock that dips gently southeast toward the Gulf of Mexico, which is approximately $120 \mathrm{mi}(190 \mathrm{~km})$ to the southeast. These strata are composed locally of sand, silt, and clay deposits of the Whitsett and Manning Clay Formations. The site is directly underlain by the Dubose Clay, Deweesville Sandstone, Conquista Clay, and Dilworth Sandstone Members of the Whitsett Formation (Jackson Group). Underlying the Dilworth Sandstone, the basal member of the Whitsett Formation is the Manning Clay Formation, the oldest geologic unit encountered during the site drilling program. Figure 2.2 is a geologic cross section showing the site stratigraphy. Figure 2.3 is a map of the surface geology.

\subsubsection{Deweesville/Conquista aquifer}

The Deweesville/Conquista aquifer includes the fine-grained sands and sandy clays of the Deweesville Sandstone, the upper Conquista Clay Member, and the middle Conquista Clay fossiliferous sandstone unit (predominantly fine-grained, slightly to moderately clayey sand). In the site vicinity, the Deweesville/ Conquista aquifer extends from land surface to the base of the middle Conquista Clay fossiliferous sandstone unit (where present), approximately 60 to $70 \mathrm{ft}$ (18 to $21 \mathrm{~m}$ ) deep.

Shallow ground water is found in the aquifer at depths of 5 to $30 \mathrm{ft}(1.5$ to $9 \mathrm{~m}$ ) below land surface. Ground water occurs under unconfined conditions in the northern and western portions of the site and along creek beds but may become confined by the Dubose Clay further downdip to the southeast. In areas where the Deweesville/Conquista aquifer is unconfined, the potentiometric surface is generally a subdued replica of the surface topography. In the immediate site vicinity, water from the milling operations has created a ground water mound that will dissipate in time. The mounded ground water is superimposed on a topographic high and surface water drainage divide. The 


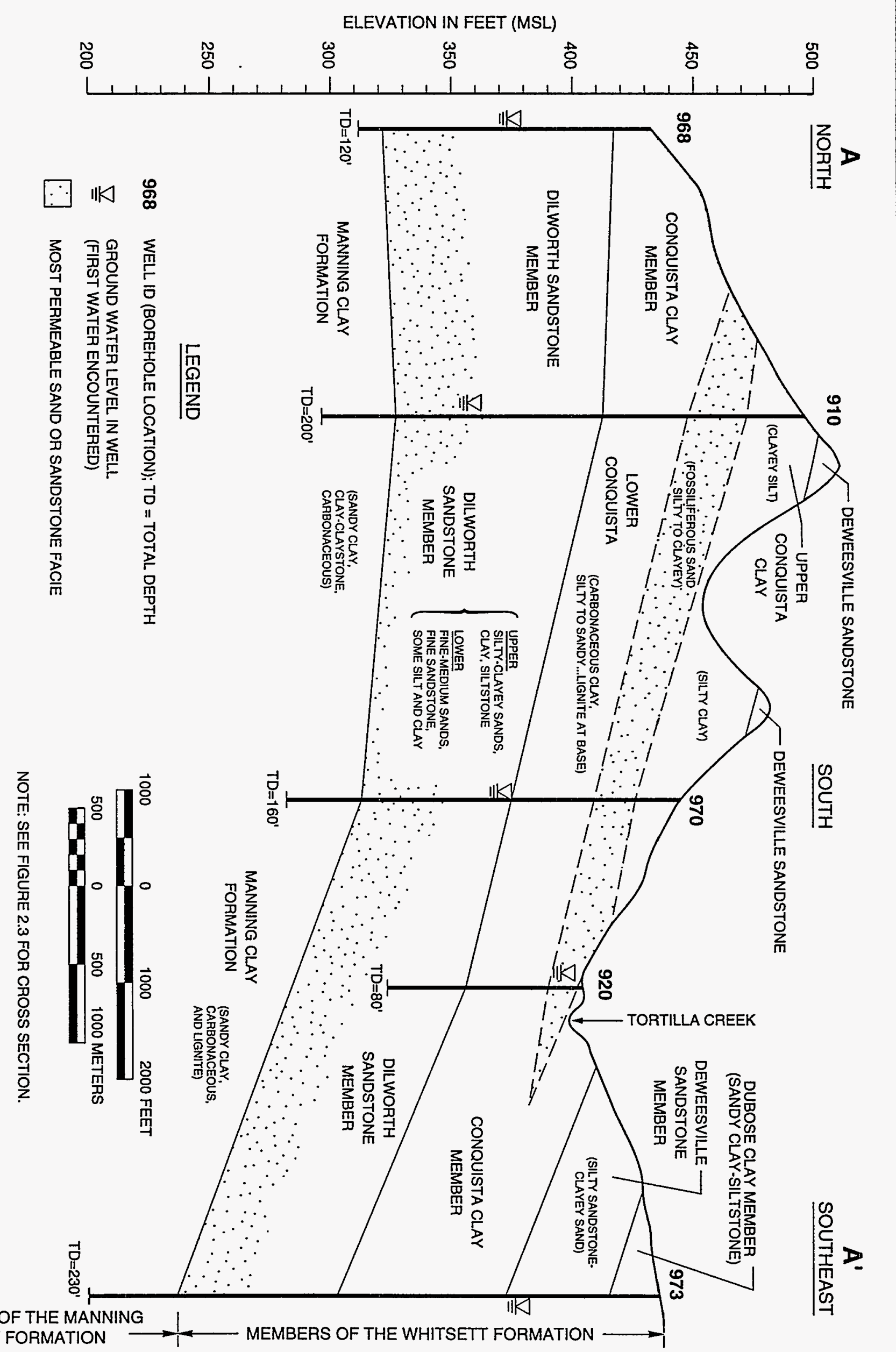




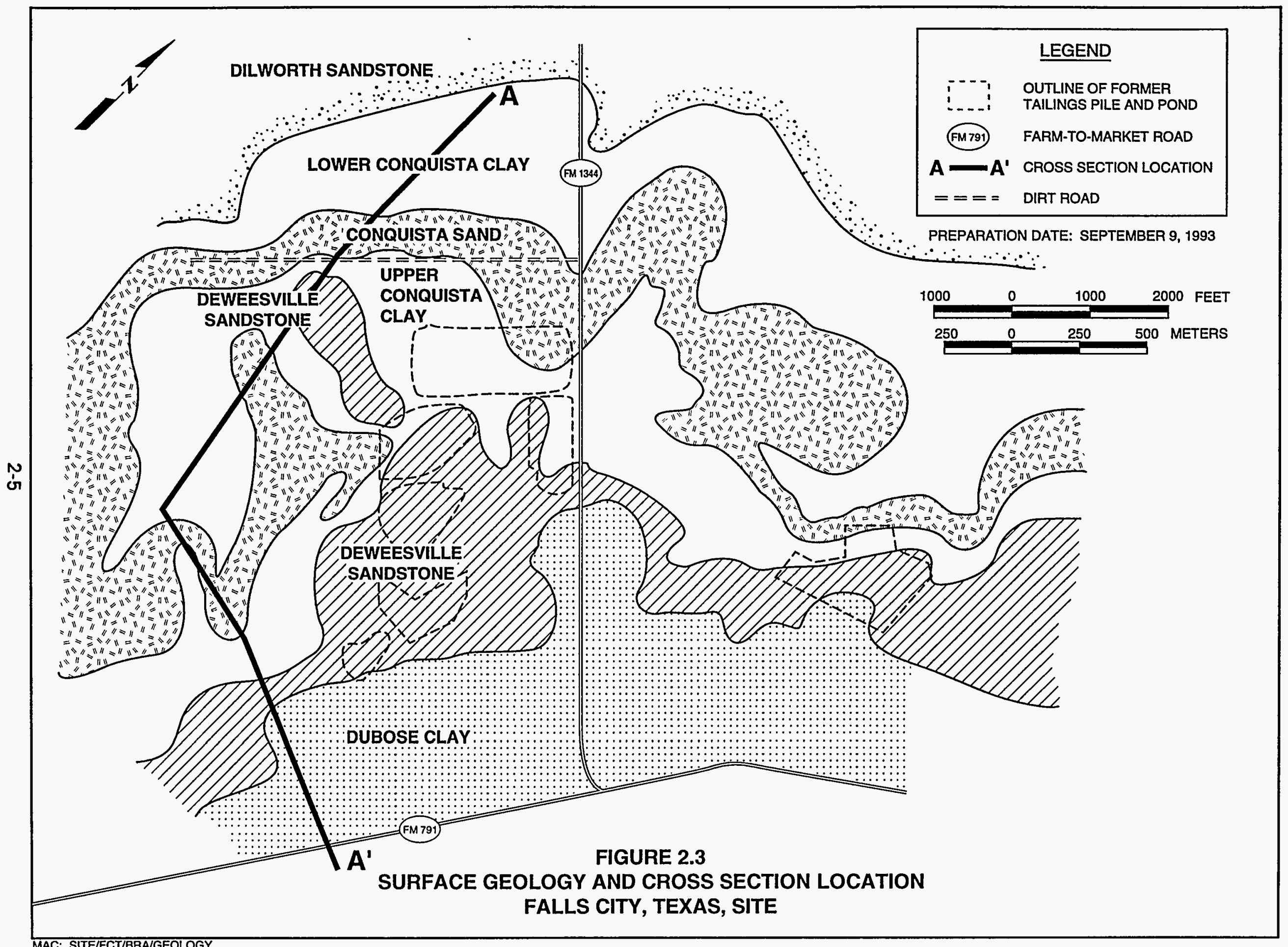


unconfined ground water south of the surface water drainage divide (Figure 2.4) flows south and southwest toward the Tordilla Creek drainage area. Shallow ground water north of the surface water drainage divide flows northeast along the Scared Dog Creek drainage area. South of the site, ground water flows southeast with the regional flow system. The potentiometric surface of the Deweesville/Conquista aquifer is shown in Figure 2.4.

Ground water within the Deweesville/Conquista aquifer is recharged by infiltrating precipitation in the Deweesville/Conquista outcrop areas (Figure 2.3), seepage from tailings fluids, and in downdip areas, interformation leakage from overlying sediments. Ground water yields for the Deweesville/Conquista aquifer are generally less than 1 gallon (4 liters [L]) per minute, but yields of up to 5 gallons $(20 \mathrm{~L})$ per minute were obtained from a monitor well screened in the fossiliferous interval of the Conquista Sandstone.

The horizontal hydraulic conductivities in the Deweesville and Conquista units are highly variable with a range of values varying 2 orders of magnitude. The maximum hydraulic conductivity for the Deweesville/Conquista aquifer was $2.6 \mathrm{ft}$ per day $\left(9.0 \times 10^{-4}\right.$ centimeters per second $\left.[\mathrm{cm} / \mathrm{s}]\right)$. This conductivity was calculated from data collected from a pumping test conducted in a well screened in the Conquista Sandstone. Using Darcy's Law and an assumed effective porosity of 0.1 and an average hydraulic gradient of 0.013 , the maximum average ground water velocity is approximately $130 \mathrm{ft}(40 \mathrm{~m})$ per year.

\subsubsection{Dilworth aquifer}

The Dilworth aquifer, a sandstone member of the Whitsett Formation, is separated from the Deweesville/Conquista aquifer by 30 to $50 \mathrm{ft}(9$ to $15 \mathrm{~m})$ of carbonaceous clay of the lower Conquista Clay Member, which acts as an aquitard to downward seepage. The semiconfined Dilworth aquifer extends to an approximate depth of $100 \mathrm{ft}(30 \mathrm{~m})$ immediately below the mill site area. The potentiometric surface in the Dilworth aquifer shows ground water flows generally southeast (downdip) and east beneath the site from the Dilworth outcrop (recharge) band northwest of the site (Figure 2.5).

Ground water within the Dilworth aquifer is recharged by infiltrating precipitation in the Dilworth outcrop areas (Figure 2.3). Ground water yields from DOE monitor wells screened in the Dilworth aquifer are generally less than 1 gallon $(4 \mathrm{~L})$ per minute.

Average linear ground water velocities in the Dilworth aquifer were calculated using a hydraulic conductivity of $0.7 \mathrm{ft}(0.2 \mathrm{~m})$ per day (approximate maximum value from pumping test), a hydraulic gradient of 0.009 to the east-southeast, and an assumed effective porosity of 0.1 for the fine sands of this zone. The average linear velocity for ground water flow in the lower Dilworth aquifer is approximately $20 \mathrm{ft}(7 \mathrm{~m})$ per year. 


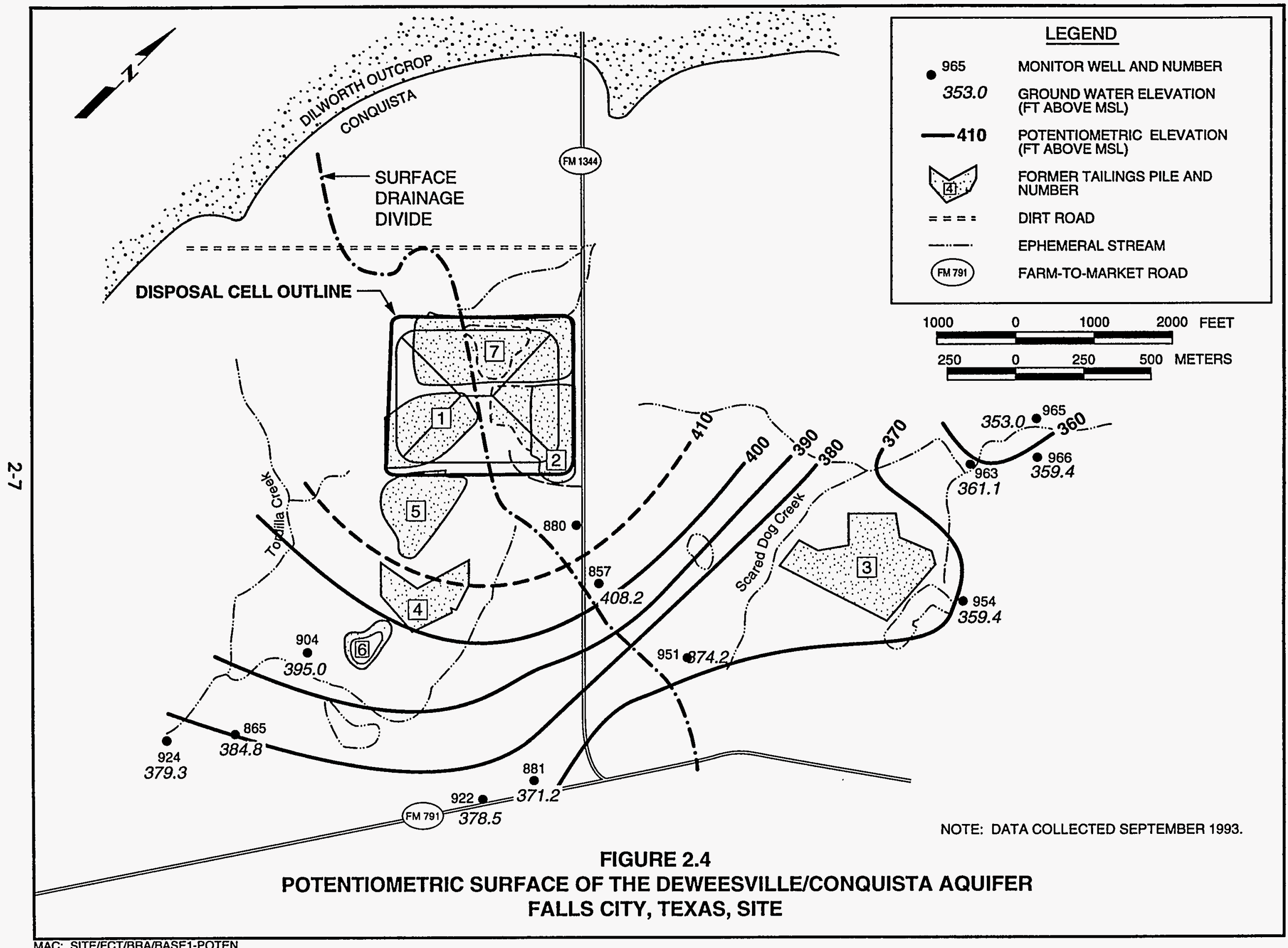




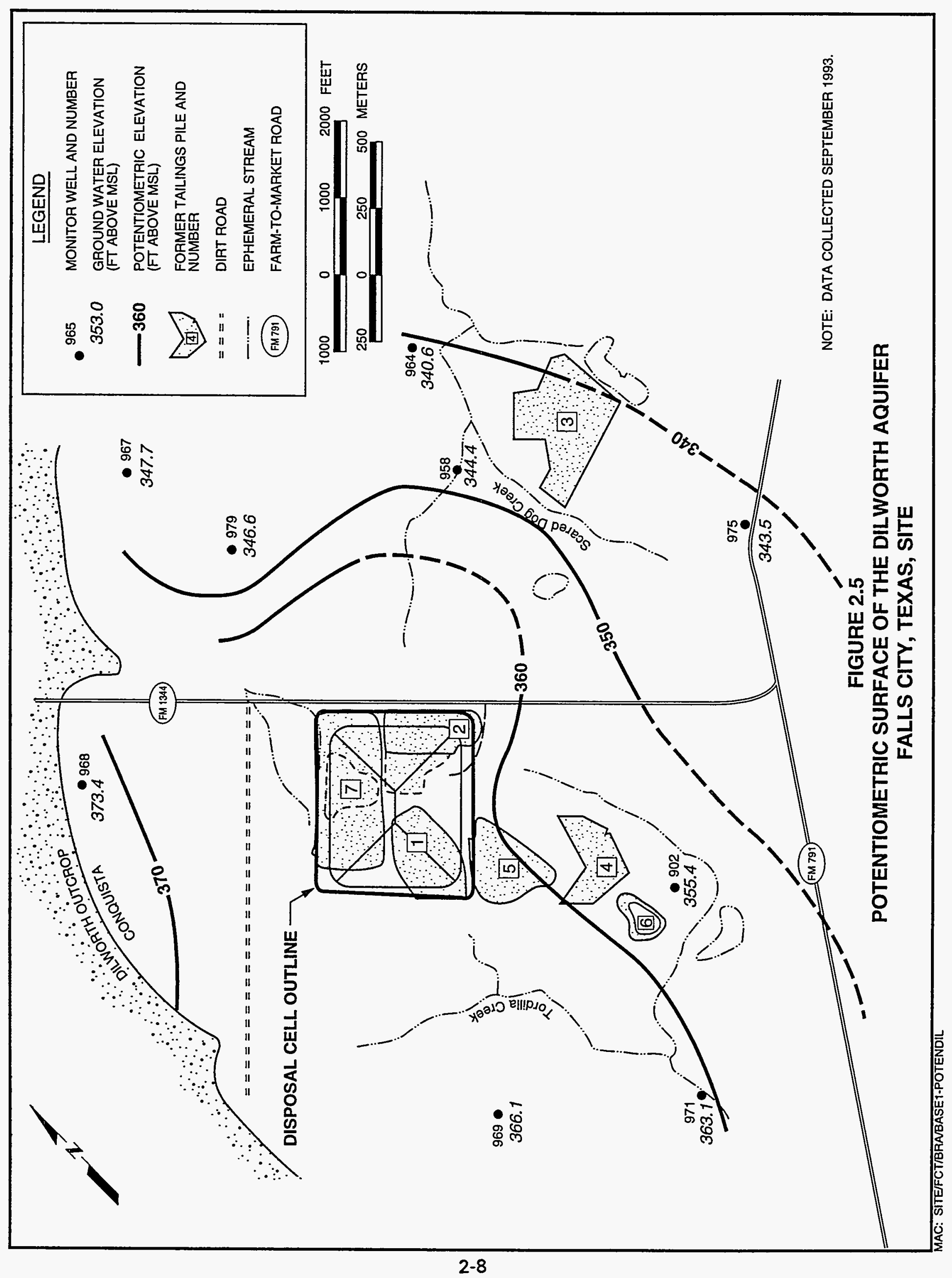




\subsubsection{Upper Manning Clay Formation}

The dominant lithology of the upper Manning Clay Formation, which functions as an aquitard, is sandy carbonaceous clay. Ground water yields from monitor wells screened in the upper Manning Clay are generally less than 1 gallon ( $4 \mathrm{~L}$ ) per minute.

\subsubsection{Yegua and Carrizo aquifers}

Beneath the Manning Formation, two other aquifers are capable of providing fresh water to slightly saline water: the Yegua and the Carrizo. The Yegua, which is beneath the Manning Clay Formation, lies at a depth of $450 \mathrm{ft}(130 \mathrm{~m})$ below the former mill site and yields small quantities of slightly saline to saline water. The Carrizo Sandstone is the major freshwater aquifer in this part of Texas. It lies at a depth of approximately $2000 \mathrm{ft}(600 \mathrm{~m})$ below the former mill site.

\subsection{SURFACE WATER}

The Falls City site is on the northwest-southeast trending drainage divide (Figure 2.4) between the San Antonio River to the northeast and the Atascosa River to the southwest. Surface drainage from the vicinity of the former piles 2 and 3 and the northern portion of piles 1 and 7 flows approximately $4 \mathrm{mi}$ $(6 \mathrm{~km})$ northeast via Scared Dog Creek to the San Antonio River. Surface drainage from former tailings ponds $1,4,5$, and 6 , as well as drainage from portions of piles 2 and 7, flows southwest via Tordilla Creek into Borrego Creek to the Atascosa River. These creeks flow only for short periods immediately after large rainstorms.

\section{$2.5 \quad$ LAND USE}

The Falls City site is in rural farm country southeast of San Antonio. Population centers in this area generally consist of small towns of 3000 to 4500 people. In 1990, the population of Karnes County was estimated at 12,455. The Falls City city hall estimated the 1993 population of Falls City to be 472 (Smith, 1993).

Many residents farm, with incomes typically supplemented by a second income. In 1955, uranium ore was discovered in the area of the site (Anders, 1962).

Several small bodies of ore are still present at the site. Open pit mining occurred at the former locations of piles $3,4,5$, and 6 . The former SWI uranium mill operated between 1961 and 1973 .

Farms in Karnes County average 300 ac (120 ha), with approximately 21 farms or partial-farm acreage in the site area (Table 2.1 and Figure 2.6). These parcels range in size from 130 to 400 ac (53 to $160 \mathrm{ha}$ ). There are also three small residential lots of approximately 4 ac $(1.6 \mathrm{ha})$ or less in the immediate site vicinity; two of these residences are within $1300 \mathrm{ft}(400 \mathrm{~m})$ of the site. Most 


\begin{tabular}{|c|c|c|c|c|c|c|}
\hline \multirow{2}{*}{ 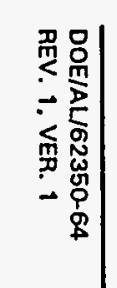 } & \multirow[b]{2}{*}{$\begin{array}{l}\text { Property } \\
\text { owner }\end{array}$} & \multicolumn{5}{|c|}{ Land use } \\
\hline & & $\begin{array}{l}\text { Size } \\
\text { (ac) }\end{array}$ & $\begin{array}{c}\text { No. of } \\
\text { occupants }\end{array}$ & Livestock & Agriculture & Other \\
\hline \multirow{18}{*}{$\frac{N}{1}$} & 1 & 335 & 0 & Beef cattle & None & None \\
\hline & 2 & 223 & 0 & Beef cattle & Hay & Uranium mine (open pit) \\
\hline & 3 & 200 & 3 & Beef cattle; hogs & $\begin{array}{l}\text { Hay, domestic vegetable } \\
\text { garden }\end{array}$ & None \\
\hline & 4 & 200 & 0 & Beef cattle & None & None \\
\hline & 5 & 4 & 2 & ND & ND & ND \\
\hline & 6 & 200 & 6 & Beef cattle; horses & Hay, oats & None \\
\hline & 7 & 330 & 0 & Beef cattle & Hay & None \\
\hline & 8 & 370 & 0 & Beef cattle & None & None \\
\hline & 9 & ND & ND & NA & NA & Uranium mine (open pit) \\
\hline & 10 & 460 & NA & NA & NA & Disposal cell \\
\hline & 11 & 4 & 1 & None & None & None \\
\hline & 12 & 2 & NA & NA & NA & Water supply company \\
\hline & 13 & 4 & None & None & None & None \\
\hline & 14 & 4 & 2 & Cows; turkeys; chickens & Domestic vegetable garden & None \\
\hline & 15 & 130 & 1 & Beef cattle & Domestic vegetable garden & None \\
\hline & 16 & 340 & 0 & Cattle & Hat, oats & Uranium mine (open pit) \\
\hline & 17 & 400 & 0 & Beef cattle & Hay & Uranium mine (open pit) \\
\hline & 18 & 200 & 0 & Sheep; goats; cattle & Hay & None \\
\hline 量学 & 19 & 150 & 0 & Cattle & ND & None \\
\hline 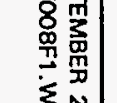 & 20 & 250 & 4 & Beef cattle; chickens & $\begin{array}{l}\text { Hay, wheat, domestic } \\
\text { vegetable garden }\end{array}$ & Uranium mine (open pit) \\
\hline
\end{tabular}




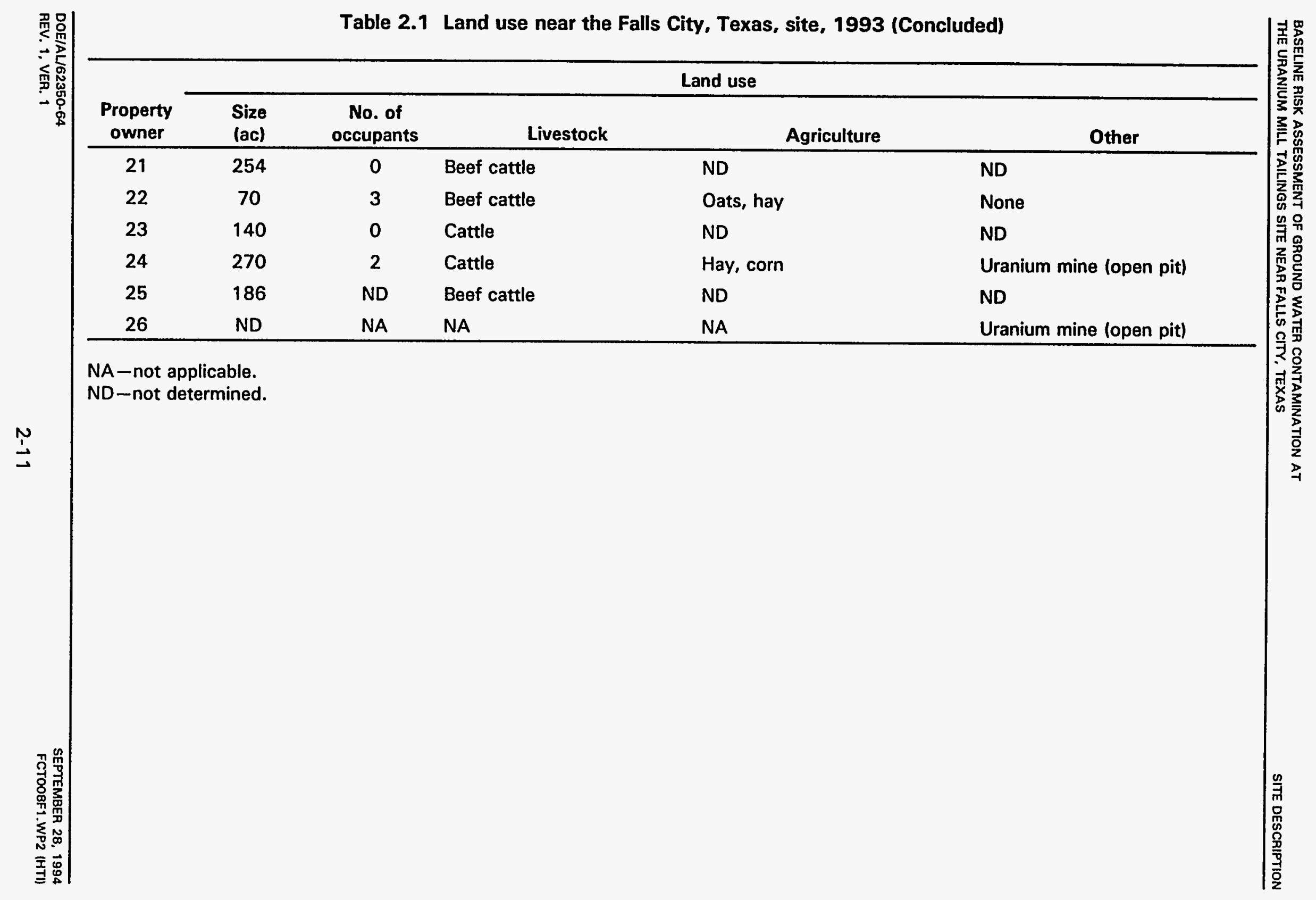




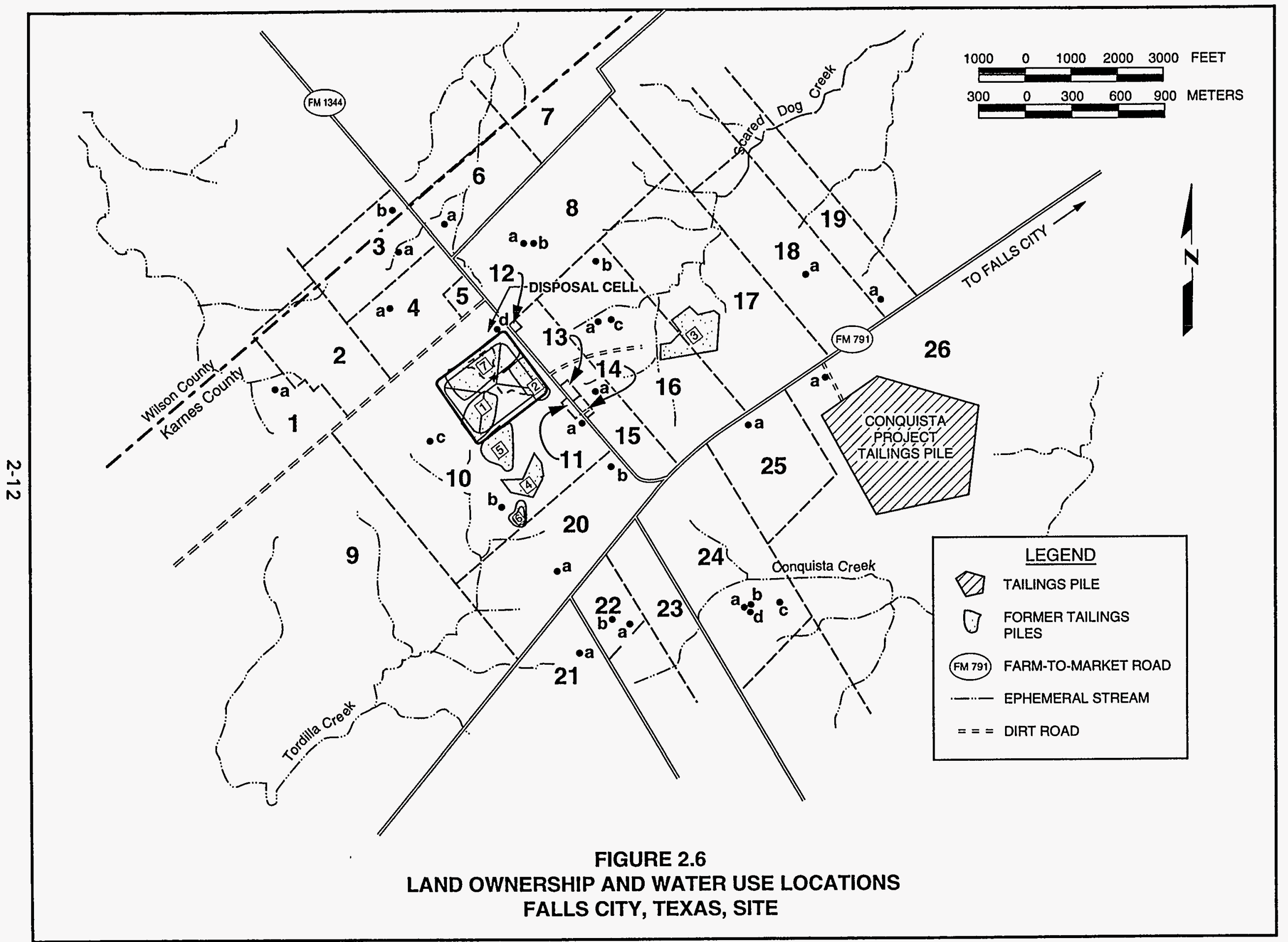


of the parcels are occupied, with the landowners of the remaining parcels either living on nearby farms, in Falls City, or in San Antonio. An estimated 30 people live within a $2-\mathrm{mi}(3-\mathrm{km})$ radius of the site. Figure 2.6 shows the ownership and occupant distribution in this area. Table 2.1 summarizes the land use and occupant information.

Most of the land surrounding the former uranium processing site is used for cattle grazing and dryland farming. Crops include hay and feed products, with most crops raised for farm consumption rather than for sale. Fairly substantial gardens are cultivated for home consumption.

Beef cattle still provide the majority of the agricultural cash receipts in Karnes County (DOE, 1991). Livestock in the site area consist primarily of beef cattle, with small poultry flocks for domestic use. One farm also raises hogs.

Formerly, dairy cattle were grazed east of former pile 3, but the owners moved the dairy herd to another farm parcel in 1988 and replaced it with a herd of beef cattle. Average herd sizes range from 15 to 55 animals. Some farmers have reported previous problems with molybdenosis from the naturally occurring molybdenum, but providing copper sulfate supplements to their animals alleviated this problem.

\subsection{WATER USE}

A ground water well records search and field reconnaissance were conducted at and near the former uranium ore processing site at Falls City in July-September 1990 and January 1994 (DOE, 1991; TAC, 1994). The results of the surveys are summarized in Table 2.2 and Figure 2.6. Detailed examination of the well records and intensive field investigation within approximately a $2-\mathrm{mi}(3-\mathrm{km})$ radius of the site have not revealed any present or historical users of the shallow Deweesville/Conquista aquifers.

Nine existing private wells appear to be completed in the Dilworth or Manning Formation and four in the deeper Yegua or Carrizo Formations. Lithologic and well construction logs do not exist to identify the lithology and screen depth intervals of these wells; therefore, information obtained from interviews with property owners was used to establish formation of completion. Although the formations of completion of other five other private wells could not be conclusively determined at this time, their depths range from about $65 \mathrm{ft}(20 \mathrm{~m})$ to about $405 \mathrm{ft}(120 \mathrm{~m})$. Some of the existing wells are presently inactive $(8$ of 18) due to extensive well casing corrosion, broken pumps, or being filled with debris.

Many of the active domestic wells have steel casings that have corroded over time, compromising the integrity of the well casing and potentially allowing seepage from the overlying water-bearing strata and surface water. For example, the domestic well within $2000 \mathrm{ft}(600 \mathrm{~m})$ of the former tailings piles (also identified as well 15a in Figure 2.6) was originally completed in the Dilworth aquifer. However, it appears that the structural integrity of this well 


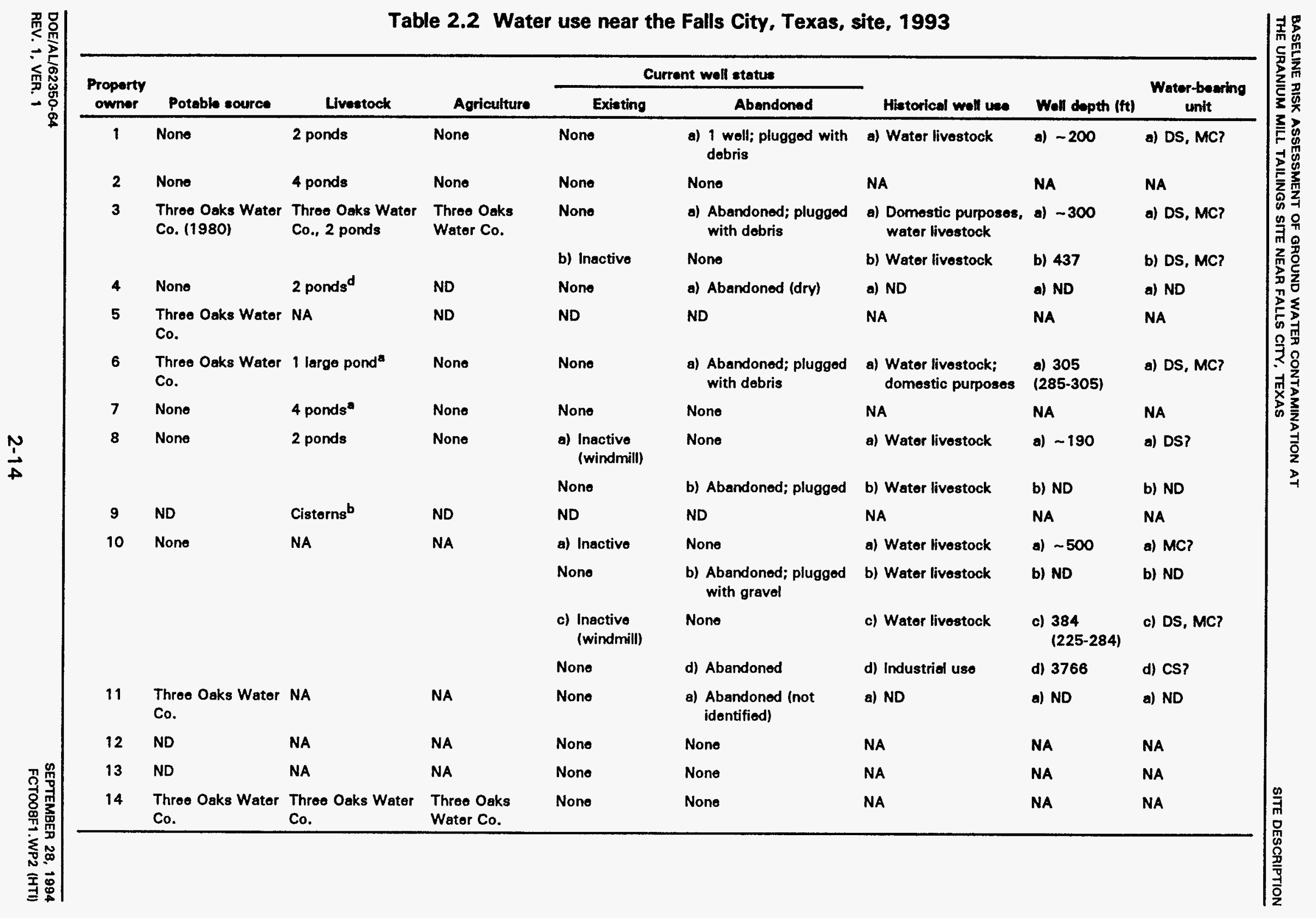




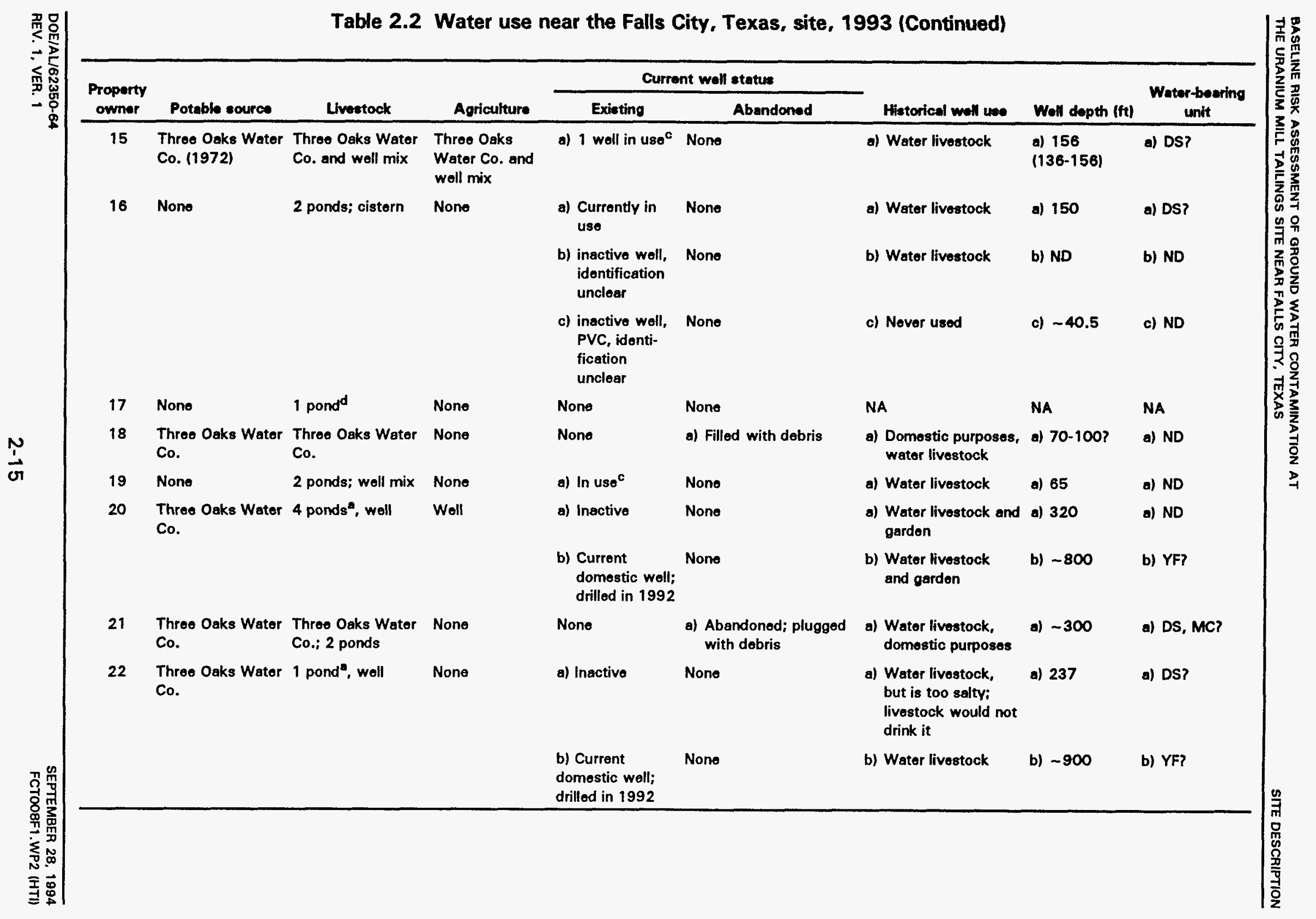




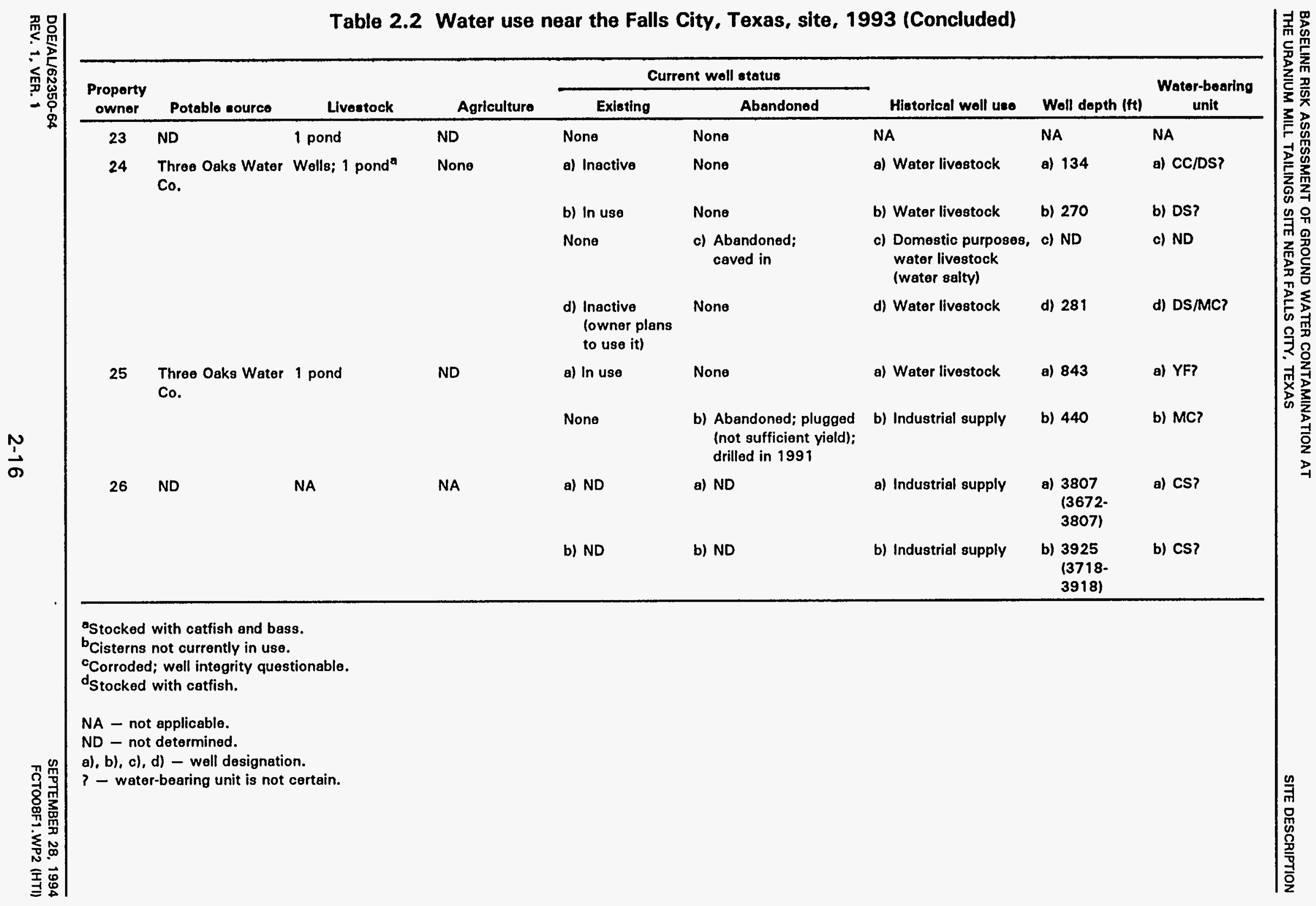


may have degraded to the extent it may be allowing seepage from the units overlying the Dilworth.

Three domestic supply wells are within the area (identified as wells 20b, 22b, and $25 \mathrm{a}$ in Figure 2.6), that are completed in a deeper, Yegua Formation.

Many of the existing domestic wells (five of nine) that may tap the Dilworth and Manning ground waters are being used to water livestock and domestic gardens. None of them is used as a drinking or domestic water supply within a $2-\mathrm{mi}(3-\mathrm{km})$ radius of the site.

Residences within the site area use deeper ground water from the Carrizo Sandstone supplied by the Three Oaks Water Cooperative for domestic and potable purposes and for stock watering (Table 2.2, Figure 2.6). This cooperative distributes water from a 2000-ft (600-m)-deep well, approximately $10 \mathrm{mi}(16 \mathrm{~km})$ northwest of the site.

The Carrizo Sandstone is a source of good-quality ground water at depths greater than $2000 \mathrm{ft}(600 \mathrm{~m})$ in the site area. The San Antonio River may also be used as an alternative water source. 


\subsection{EXTENT OF CONTAMINATION}

The contaminated units at this site are the shallow, generally unconfined,

Deweesville/Conquista aquifer and the deeper, generally semiconfined to confined Dilworth aquifer. Figure 3.1 presents a generalized map of the Falls City site showing the locations of the former tailings piles and the monitor well network. Background water quality, the magnitude and extent of contamination, and the contaminants of potential concern for the Falls City site are discussed below.

\subsection{BACKGROUND GROUND WATER QUALITY}

Background ground water quality for the Deweesville/Conquista and Dilworth aquifers is defined as the quality of ground water that would be present if uranium processing activities had not occurred.

Determination of both background water quality and the extent of contamination at the Falls City site is difficult because of several complicating factors. First, there are no premilling data for water quality at the site. Second, the Deweesville/Conquista aquifer cannot be sampled upgradient of the site because tailings were placed on the outcrops that recharge the units. IUpradient sampling locations are, however, available for the Dilworth aquifer.) Therefore, there is no upgradient sampling location for the Deweesville/Conquista aquifer and background water quality must be determined from monitor wells located sufficiently downgradient to be beyond the influence of contamination from tailings piles. However, geochemical conditions in the Dilworth and Deweesville/Conquista aquifers vary from oxidized (near the outcrop) to reduced (downgradient of the site), and ground water quality far downgradient of the site is not necessarily representative of water quality in the upgradient, oxidized portion of the aquifer.

An additional complicating factor is that the tailings are located in an area that was mined for shallow, oxidized uranium ores (Figure 3.2). Nearly all the major, minor, and trace elements associated with the milling process also occur naturally because they have leached into the ground water from the remnant mineralization (Figure 3.3). Therefore, it is difficult to determine whether the concentrations of constituents in ground water reflects contamination or mineralization. Thus, the extreme variability and mineralized nature of water in the area prior to milling operations make it very difficult to establish background ground water quality.

Regional data have been examined to provide a frame of reference for background ground water quality in the vicinity of the UMTRA Project site. The results of these studies are discussed in the remedial action plan (RAP) (DOE, 1992) and below. These regional data include water quality data collected from wells installed by Conoco, Inc., as part of a regional monitoring network for the Conquista project, and water quality data collected by Texaco to establish premining water quality in Deweesville Sandstone near Hobson, Texas (Figure 3.2). 


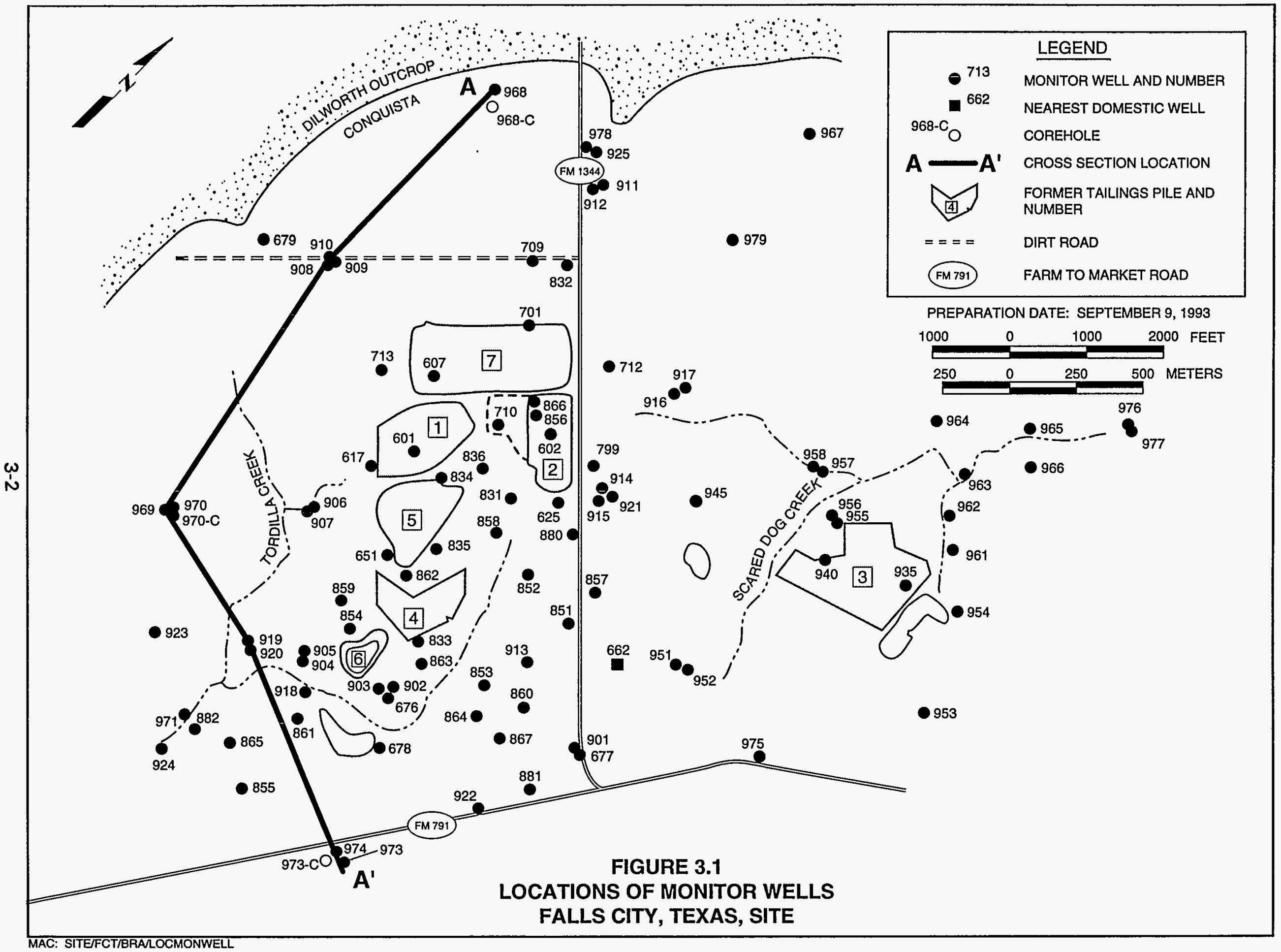




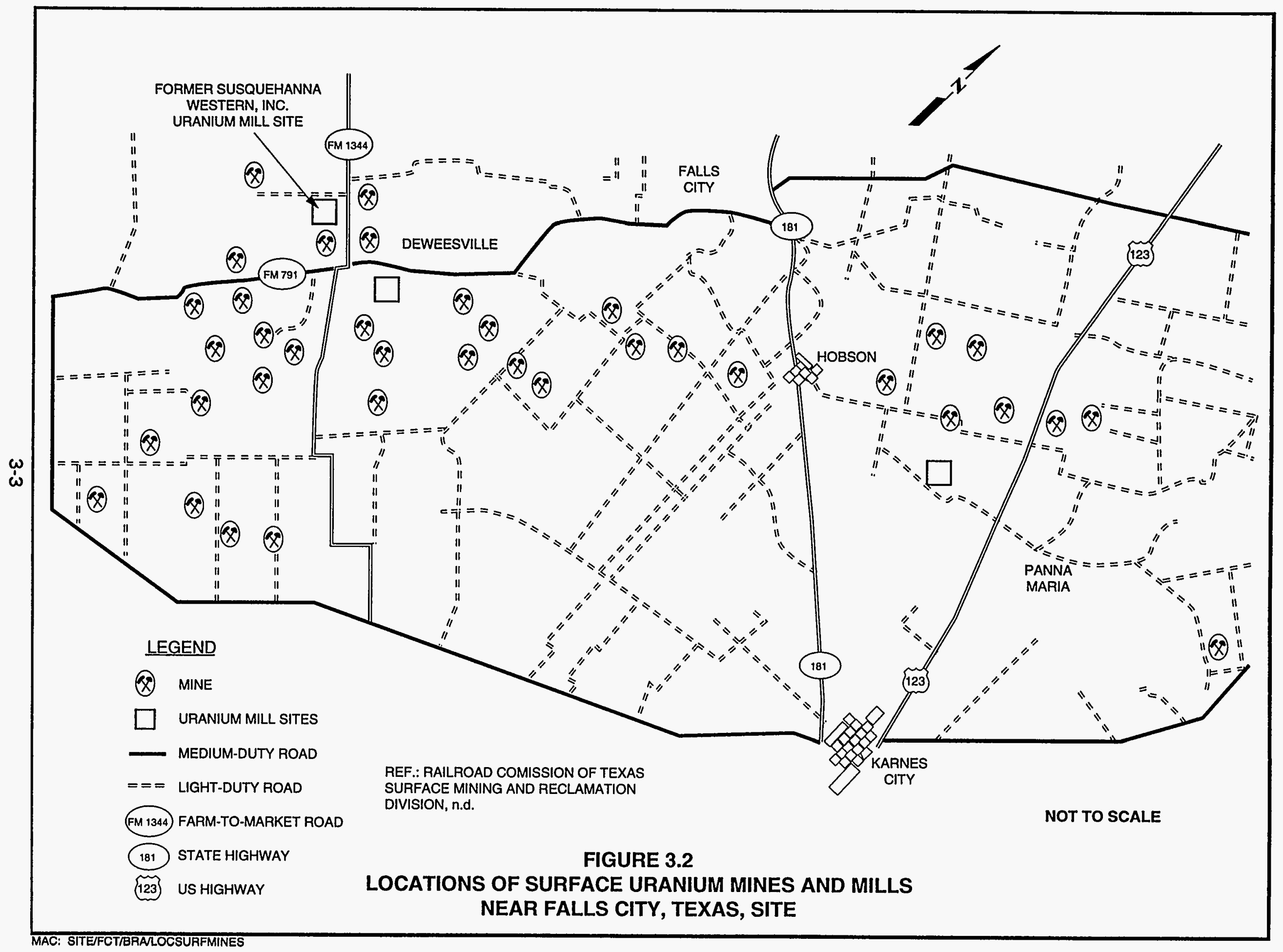




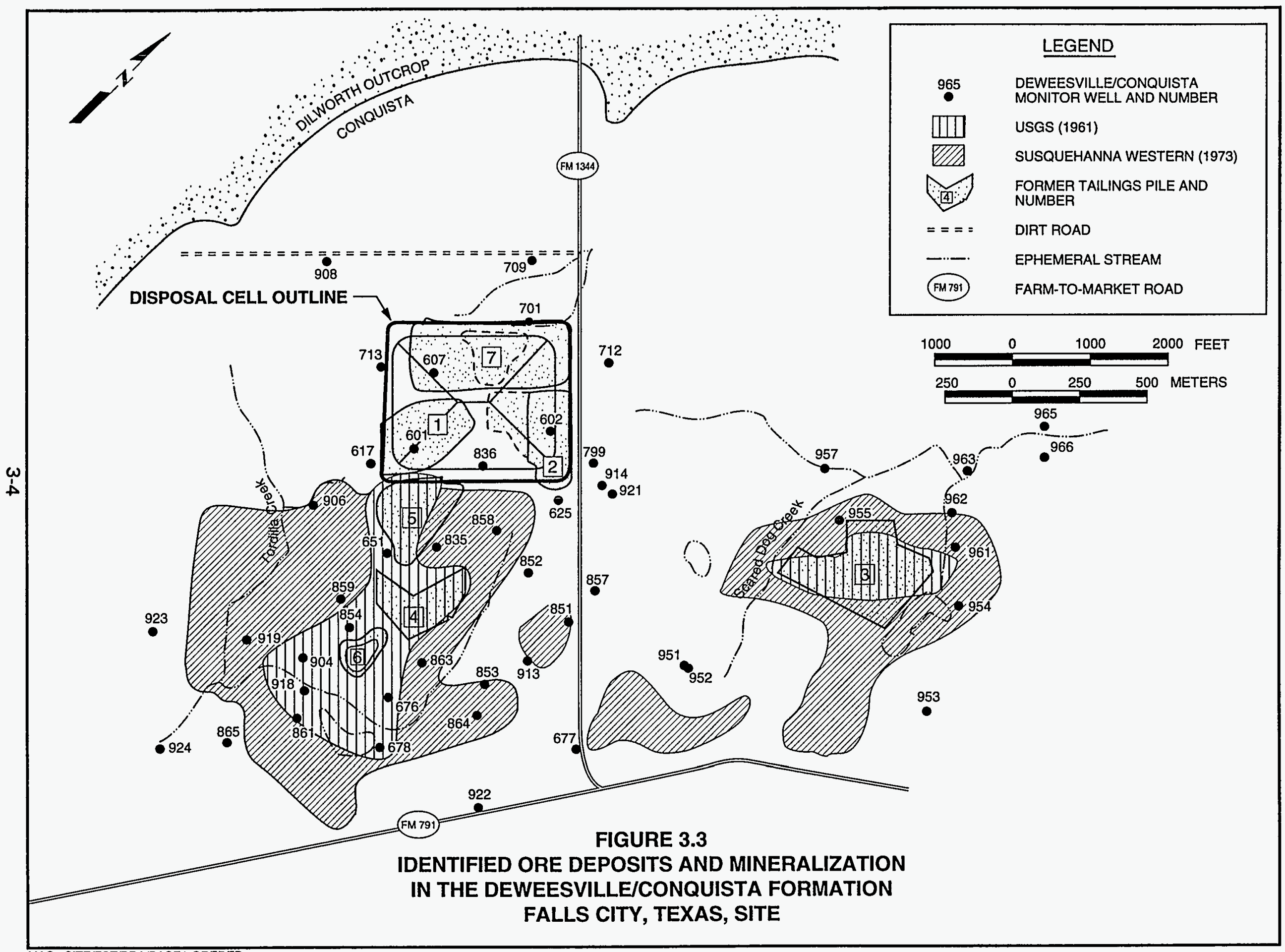


Ground water quality data from Conoco monitor wells 667 and 668 , in reduced sediments downgradient and crossgradient from the Falls City site (Figure 3.4), are summarized in Table 3.1. Ground water from these wells has relatively high chloride (up to 1090 milligrams per liter [mg/L]) and sulfate (up to $1043 \mathrm{mg} / \mathrm{L}$ ) and is classified as sodium-chloride-sulfate water (Figure 3.5). Uranium concentrations are in the range of 0.015 to $0.022 \mathrm{mg} / \mathrm{L}$. Other trace metals present include arsenic (up to $0.02 \mathrm{mg} / \mathrm{L}$ ), iron (up to $0.45 \mathrm{mg} / \mathrm{L}$ ), and manganese (up to $0.8 \mathrm{mg} / \mathrm{L}$ ).

Thirty-nine monitor wells were completed in the Deweesville Sandstone prior to mining activities at the Hobson in situ uranium mine site approximately 8 or $9 \mathrm{mi}$ $(13$ or $14 \mathrm{~km})$ east of the Falls City UMTRA site. Of these 39 wells, 28 were completed in the ore body (mine zone) and the remaining 11 were completed around the ore body (in the production zone). A statistical summary of water quality data obtained from these Deweesville monitor wells is presented in Table 3.1.

The Deweesville wells at the Hobson site are generally screened between 300 to $450 \mathrm{ft}(90$ to $140 \mathrm{~m})$ below land surface and are within the reduced zone of the aquifer. A trilinear plot of the 11 Hobson wells drilled around the ore body is shown on Figure 3.5. Ground water from these wells is a sodium-chloride type, with relatively high concentrations of arsenic (up to $0.09 \mathrm{mg} / \mathrm{L}$ ), copper (up to $0.5 \mathrm{mg} / \mathrm{L}$ ), iron (up to $5.8 \mathrm{mg} / \mathrm{L}$ ), lead (up to $0.15 \mathrm{mg} / \mathrm{L}$ ), manganese (up to $0.4 \mathrm{mg} / \mathrm{L}$ ), molybdenum (up to $0.2 \mathrm{mg} / \mathrm{L}$ ), radium-226 (up to 1023 picocuries per liter [pCi/L]), selenium (up to $0.06 \mathrm{mg} / \mathrm{L}$ ), and uranium (up to $11 \mathrm{mg} / \mathrm{L}$ ) demonstrate the influence of uranium mineralization on ground water quality in the region.

\subsubsection{Deweesville/Conquista}

The oxidized zone of the Deweesville/Conquista is defined as the outcrop area and the shallow subsurface where sediments are oxidized. At the Falls city UMTRA site, this zone includes the area where the former tailings piles where located. To date, no background ground water quality has been determined within this zone of the Deweesville/Conquista. As was discussed above, there is no upgradient sampling location in the aquifer and monitor wells placed crossgradient to the former tailings have either been dry or shown evidence of contamination. Thus, background ground water quality has not been established for this portion of the aquifer.

The transition to reduced sediments begins at the downdip edge of the Deweesville/Conquista outcrop (where the sediments are dominantly oxidized) and ends at about the downgradient limit of the DOE monitor well array (e.g., 922 and 881 ) where the sediments are dominantly reduced. Background ground water quality in this transitional zone may be represented by monitor well 951 . This well is about 1000 feet $(300 \mathrm{~m})$ downgradient from the known extent of contamination and available chemical data (DOE, 1992) indicate this 


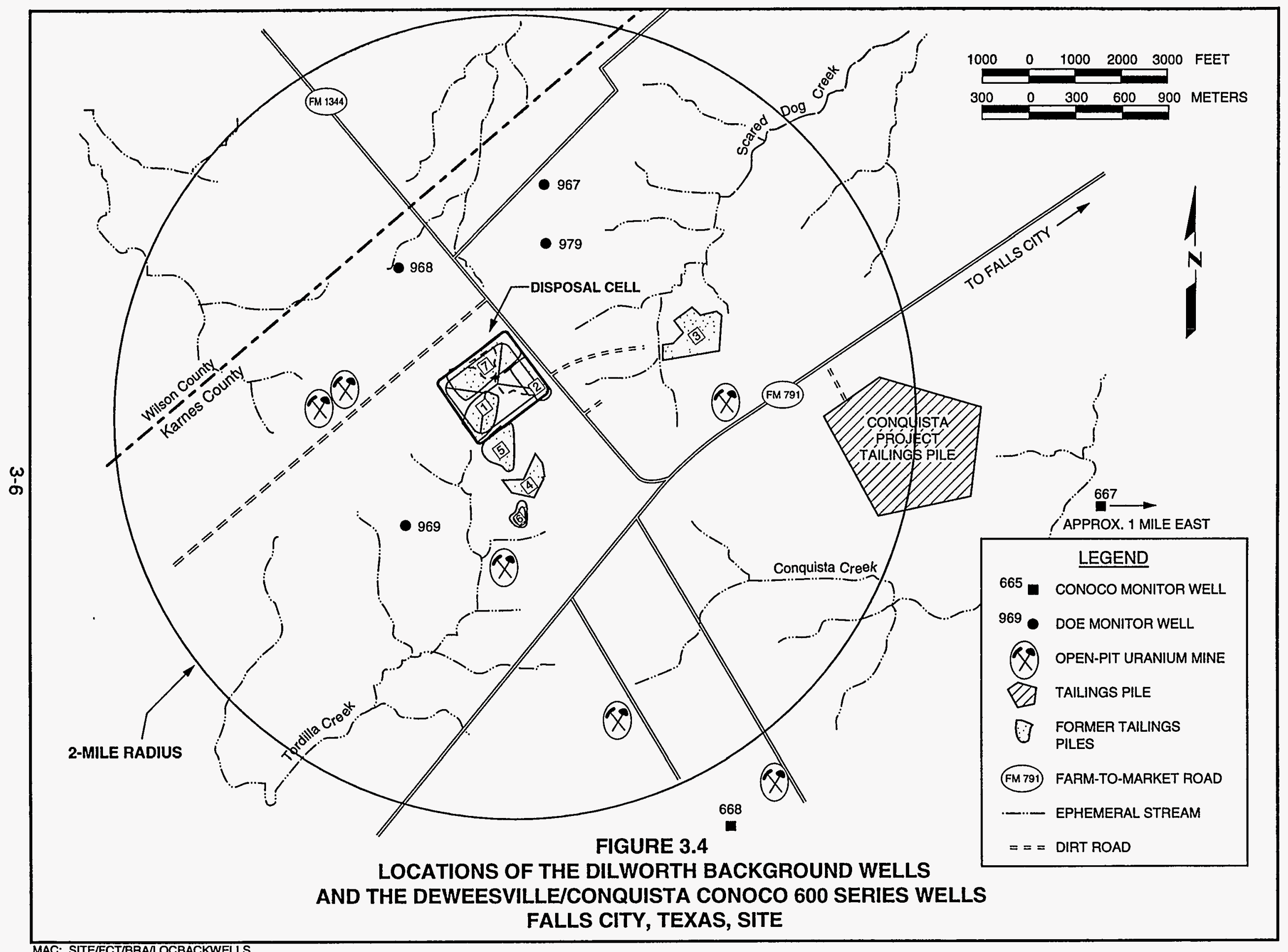




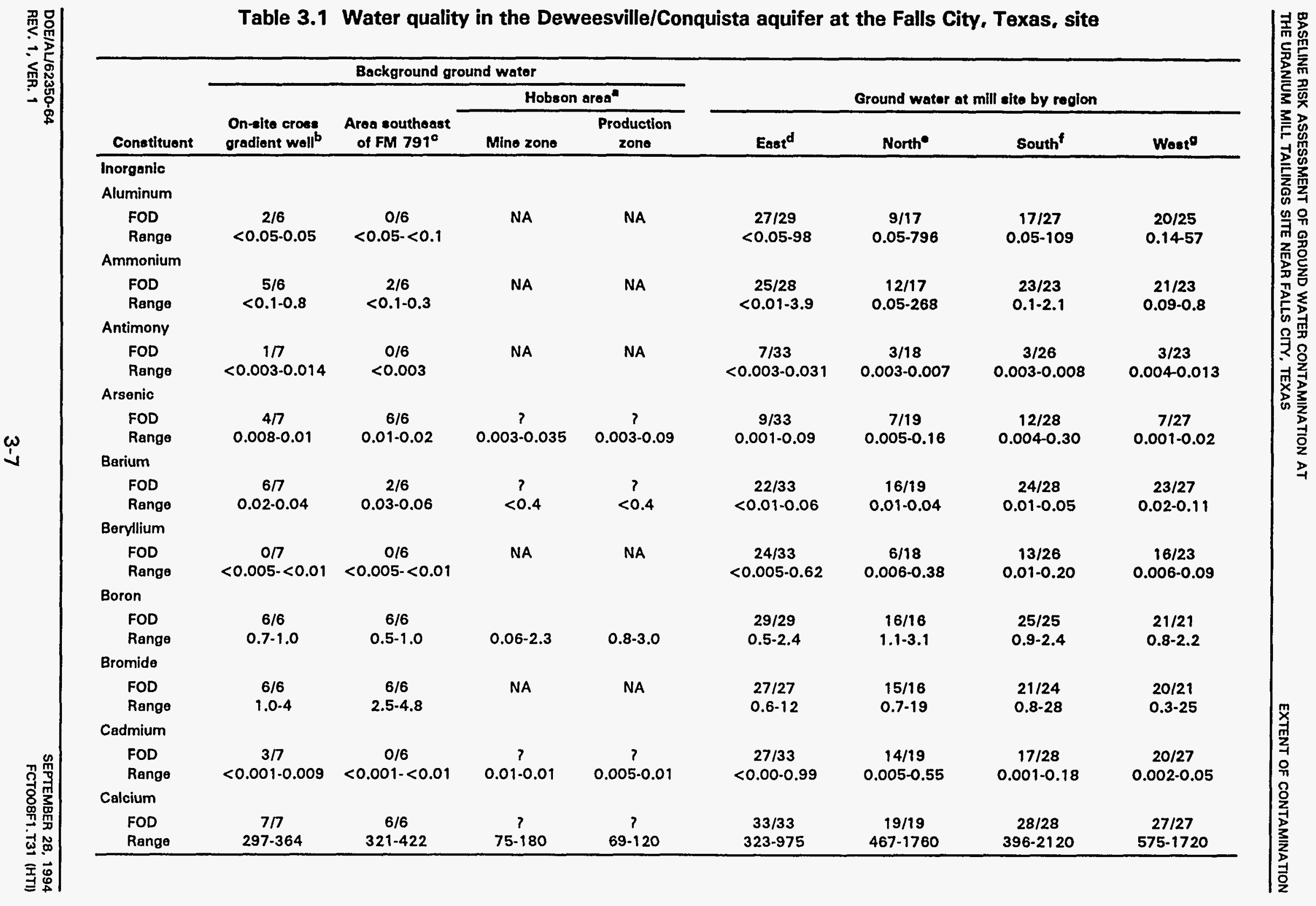




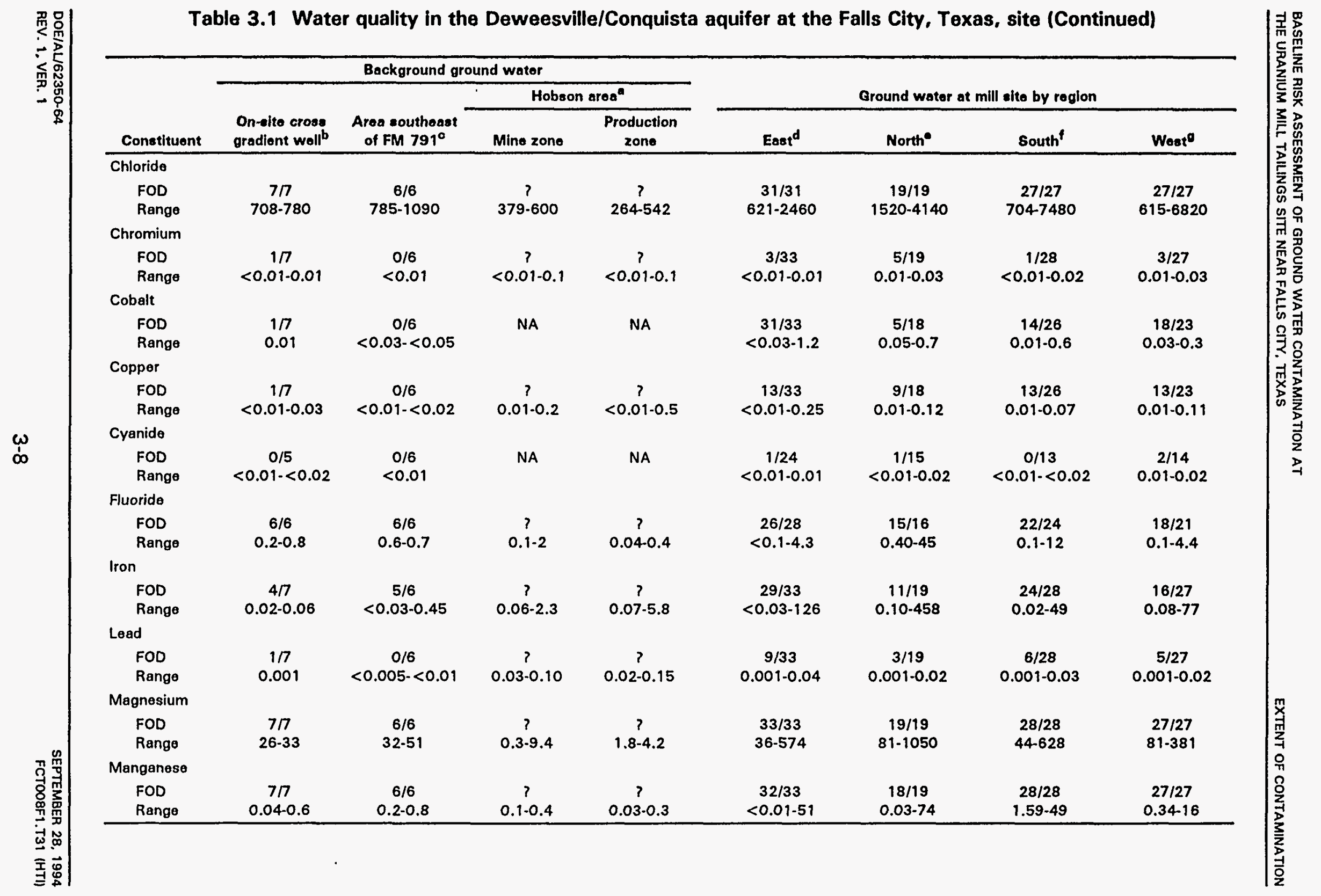




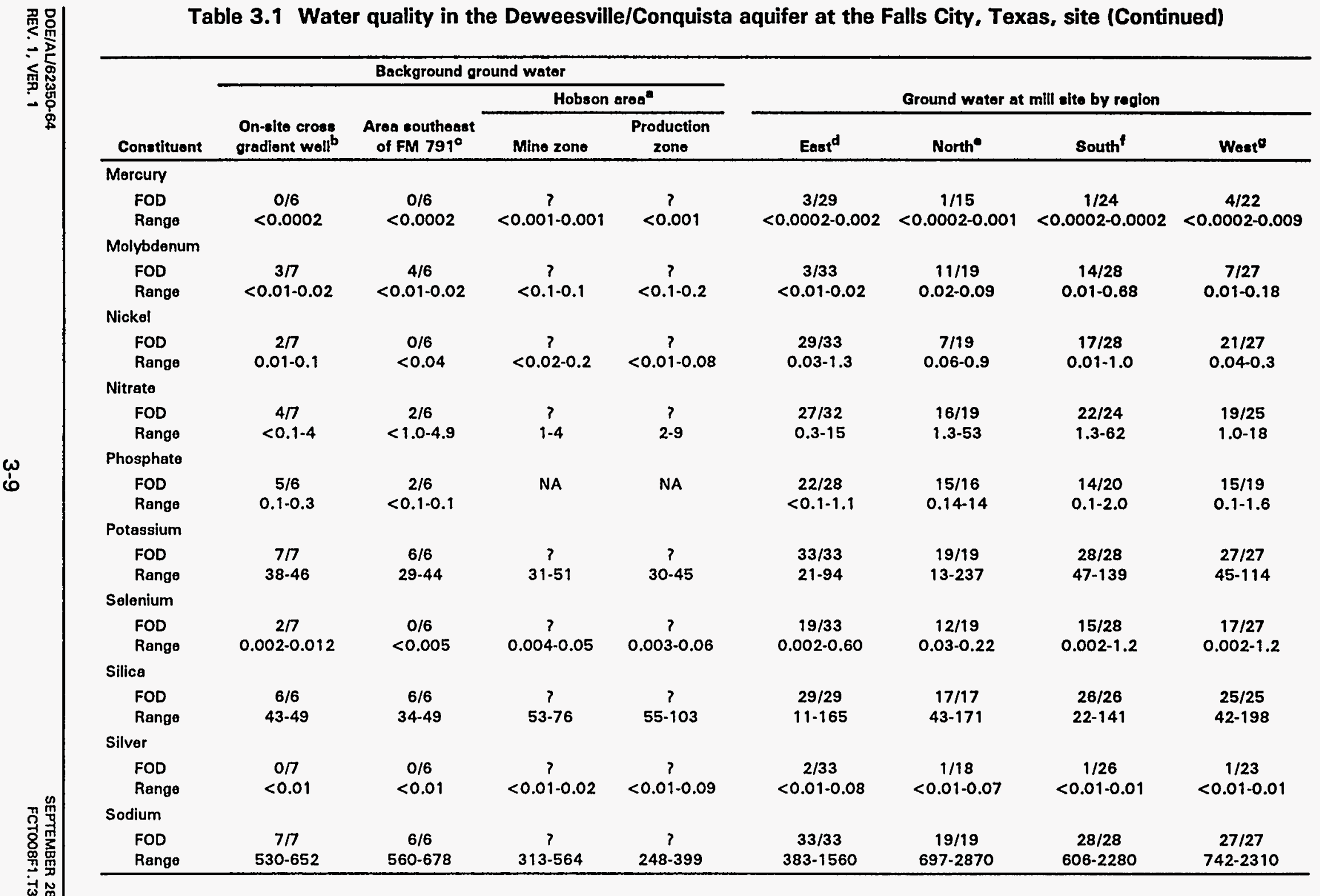




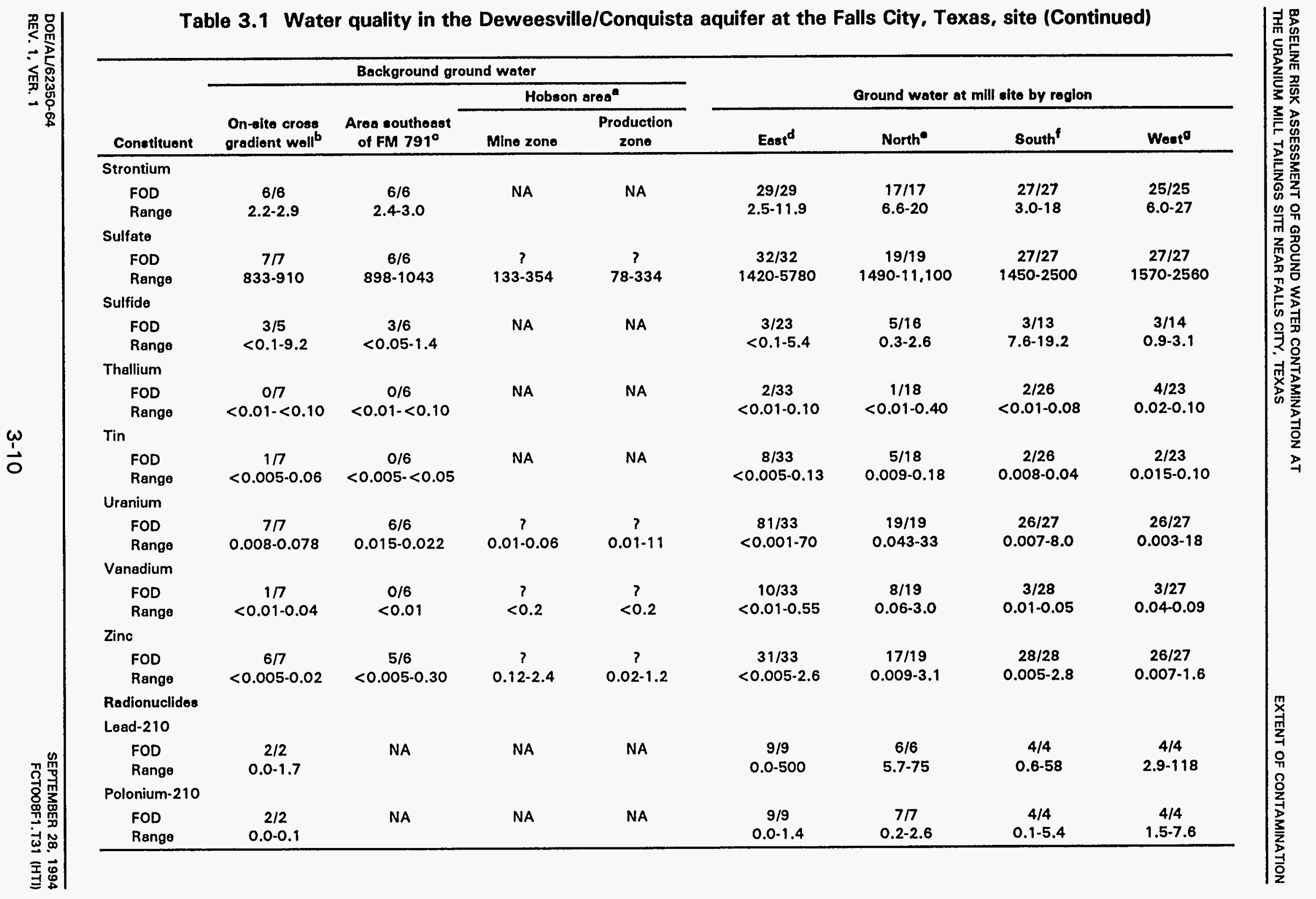


Table 3.1 Water quality in the Deweesville/Conquista aquifer at the Falls City, Texas, site (Concluded)

\begin{tabular}{|c|c|c|c|c|c|c|c|c|}
\hline \multirow[b]{3}{*}{ Constituont } & \multicolumn{4}{|c|}{ Background ground water } & & & & \\
\hline & \multirow[b]{2}{*}{$\begin{array}{l}\text { On-site crose } \\
\text { gradient well }\end{array}$} & \multirow[b]{2}{*}{$\begin{array}{c}\text { Aroe southeast } \\
\text { of FM } 791^{\circ}\end{array}$} & \multicolumn{2}{|c|}{ Hobson aroa" } & \multicolumn{4}{|c|}{ Ground water at mill ste by region } \\
\hline & & & Mine zone & $\begin{array}{l}\text { Production } \\
\text { zone }\end{array}$ & East ${ }^{d}$ & North & Sousth & Wostg \\
\hline \multicolumn{9}{|l|}{ Radium-226 } \\
\hline $\begin{array}{l}\text { FOD } \\
\text { Range }\end{array}$ & $\begin{array}{c}7 / 7 \\
1.3-2.7\end{array}$ & $\begin{array}{c}6 / 6 \\
1.9-2.8\end{array}$ & $\stackrel{?}{0.4-15.5}$ & $\stackrel{?}{3.7-1023}$ & $\begin{array}{l}33 / 33 \\
0.0-14\end{array}$ & $\begin{array}{l}18 / 18 \\
1.1-34\end{array}$ & $\begin{array}{c}27 / 27 \\
0.4-140\end{array}$ & $\begin{array}{c}27 / 27 \\
0.2-654\end{array}$ \\
\hline \multicolumn{9}{|l|}{ Thorium-230 } \\
\hline $\begin{array}{l}\text { FOD } \\
\text { Range }\end{array}$ & $\begin{array}{c}2 / 2 \\
0.1-0.4\end{array}$ & NA & NA & NA & $\begin{array}{c}9 / 9 \\
0.0-8.1\end{array}$ & $\begin{array}{c}8 / 8 \\
0.0-46\end{array}$ & $\begin{array}{c}7 \pi \\
0.2-3.6\end{array}$ & $\begin{array}{c}8 / 8 \\
0.2-54\end{array}$ \\
\hline
\end{tabular}

"Near mine zone - H102, H48, B110, B46, B98, B99, B100, B108, B109, B40, B42, with 11 ground water semples collected from these wells from 1979 to

1981. Production zone wells - T6-A, M95, M94, M93, T92, M10, M9, M7, M5, M3, T95A, M96, M97, M98, P100, P101, $1102,1103,1104,1105,1106,1107$. M16, M96, M97, M98, H96, H97; 28 ground water samples were collected from these wells from 1978 to 1979.

bMonitor wall 951.

${ }^{\mathrm{C}}$ Monitor wolls 667 and 668 . Filtered-sample data are from 1991.

dWells $940,953,955,963,965,966$.

Wells 625, 713, 799, 880, 914, 921 .

fWells 677, 853, 860, 864, 867, 881, 913.

OWells 854, 859, $882,904,918,919$.

NA - data not available (sample was not analyzed for this constituent).

$?$ - detection limit not reported.

FOD - frequency of detection; the number of measurements at or above detection limits divided by total number of measurements.

Notes: 1. Filtered samples 1989 to April 1993, except as noted.

2. Concentrations are reported in milligrams per liter, except radionuclides which are reported in picocuries per liter. 


\begin{tabular}{|ll|}
\hline LEGEND \\
\hline 1 & $H-102$ \\
2 & $H-4 B$ \\
3 & $\mathrm{~B}-110$ \\
4 & $\mathrm{~B}-46$ \\
5 & $\mathrm{~B}-98$ \\
6 & $\mathrm{~B}-99$ \\
7 & $\mathrm{~B}-100$ \\
8 & $\mathrm{~B}-108$ \\
9 & $\mathrm{~B}-109$ \\
$\mathrm{~A}$ & $\mathrm{~B}-40$ \\
$\mathrm{~B}$ & $\mathrm{~B}-42$ \\
$\mathrm{C}$ & 667 \\
$\mathrm{D}$ & 668 \\
\hline
\end{tabular}

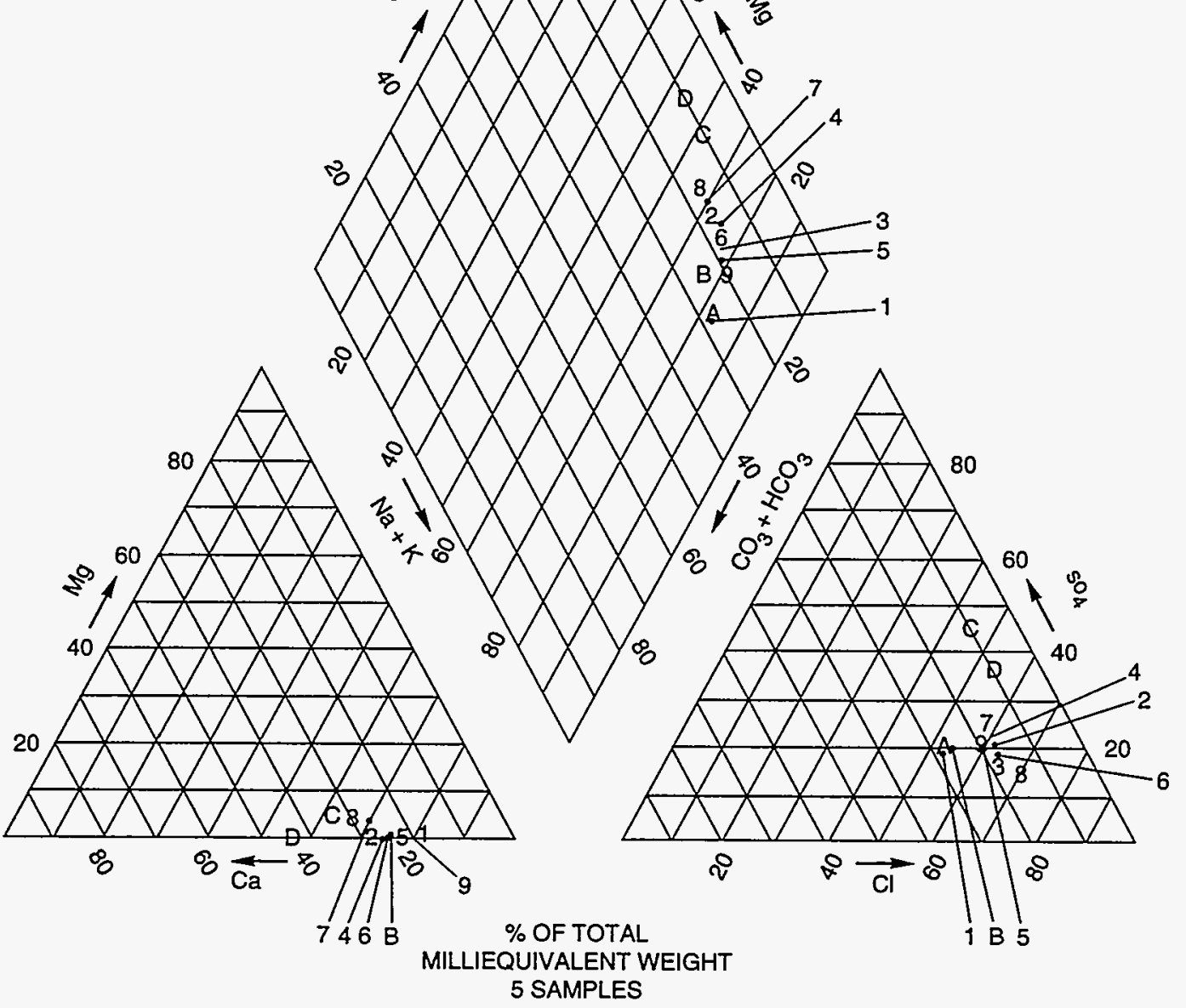

FIGURE 3.5

TRILINEAR PLOT OF DATA FROM THE DEWEESVILLE/CONQUISTA MONITOR WELLS 667, 668, AND SELECTED HOBSON DEWEESVILLE MONITOR WELLS FALLS CITY, TEXAS, SITE 
monitor well has not been affected by contaminants associated with former milling operations. The well is in the vicinity of identified uranium ore deposits (Figure 3.3) as reflected in uranium concentrations in ground water sampled from this well (up to $0.78 \mathrm{mg} / \mathrm{L}$ ). A summary of water quality data is provided in Table 3.1. Ground water from this well is sodium-chloride-sulfate type water (Figure 3.6).

Two other wells completed in the Deweesville/Conquista (monitor wells 922 and 924) were identified as background wells in previous studies (DOE, 1992). However, additional monitor wells installed since that time (wells 881 and 882; Figure 3.1) indicate that these wells are too close (within about $200 \mathrm{ft}[60 \mathrm{~m}]$ or less) to the downgradient edge of contamination to be considered background.

Thus, the range of background water quality in the Deweesville/Conquista aquifer remains to be sufficiently characterized to determine the full suite of constituents of potential concern that are attributable to uranium processing. For this risk assessment, monitor well 951 is considered a reference well for the natural ground water quality in the transition zone of the Deweesville/Conquista aquifer. It is not used as a background well for statistical comparison to contaminated wells because a single well is not representative of the potential range in background water quality at the Falls City site.

\subsubsection{Dilworth}

Four upgradient Dilworth monitor wells $(967,968,969$, and 979) have been used to define the background ground water quality of this aquifer at the Falls City site. Data on well completions and sampling are provided in Table 3.2. As shown on a trilinear plot (Figure 3.6), the upgradient Dilworth ground waters are not dominated by a single anionic species and contain about equal milliequivalents of sulfate and chloride with lesser bicarbonate. Sodium and calcium are the dominant cations. A statistical summary of the ground water quality data for the Dilworth background ground waters is presented in Table 3.3.

Of the four DOE Dilworth background wells at the UMTRA site, three 1967 , 968, and 979) are completed in the oxidized zone, and one (969) is screened in the transition to reduced sediments in the aquifer. The chemistry of the background ground water from monitor well 969 is distinct from that of the ground water sampled from the other three background wells. Generally, background ground water from monitor well 969 has higher total dissolved solids (TDS), sulfate, chloride, calcium, alkalinity, manganese, and iron than ground water from the other Dilworth background monitor wells. These differences in water quality are generally consistent with ground water from monitor wells 967,968 , and 979 , being closer to point of recharge. The greater distance of monitor well 969 from the outcrop and recharge area and the higher TDS, sulfate, iron, and manganese concentrations in the ground water are consistent with longer aquifer residence times and the oxidation of pyrite under conditions that are sufficiently reducing to stabilize iron and 

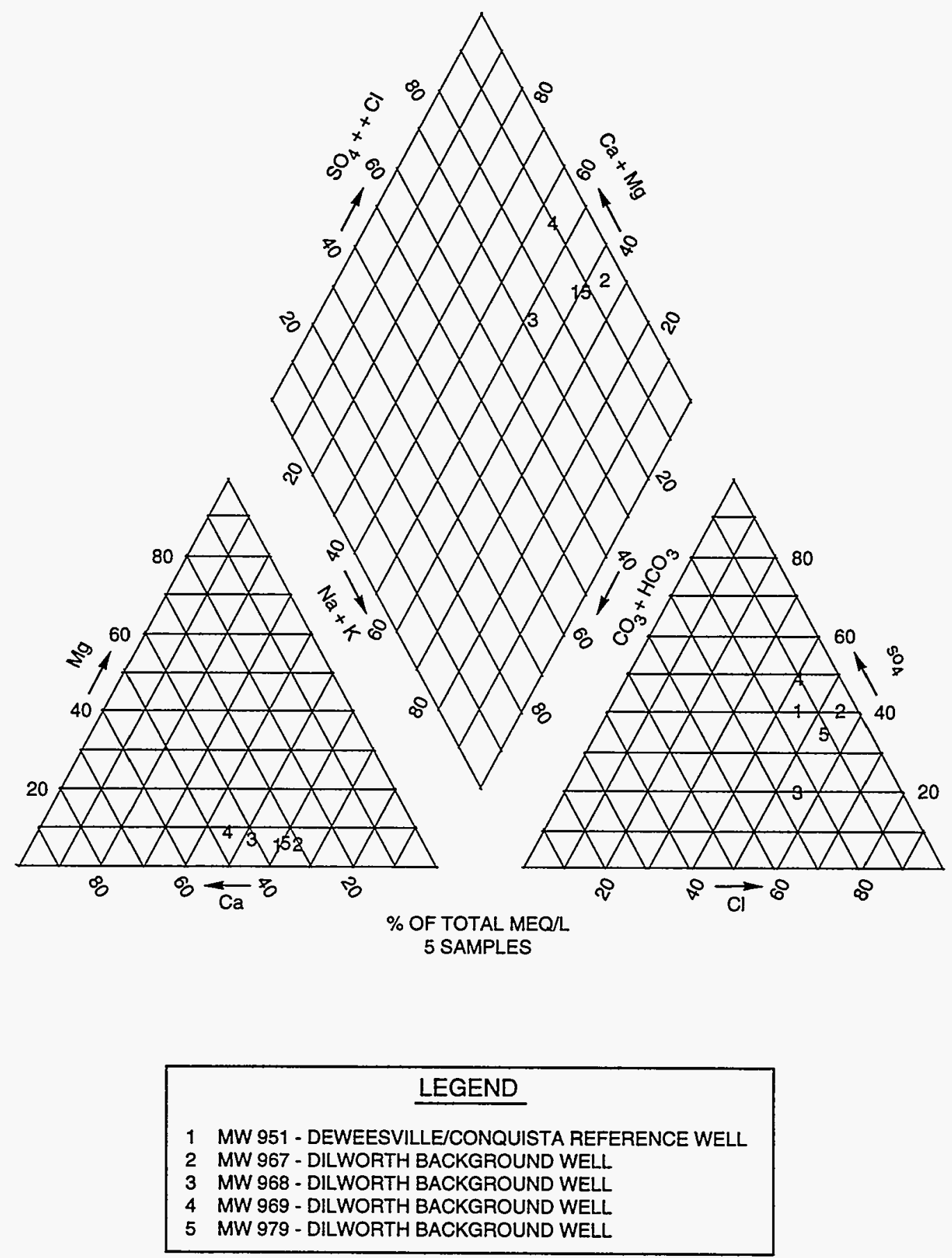

FIGURE 3.6

TRILINEAR PLOT OF THE DILWORTH BACKGROUND GROUND WATER AND THE DEWEESVILLE/CONQUISTA REFERENCE WATER

FALLS CITY, TEXAS, SITE 
Table 3.2 Well completion and sampling, Dilworth aquifer background wells and contaminated wells

\begin{tabular}{lcccc}
\hline Location ID & Years sampled & $\begin{array}{c}\text { Number of } \\
\text { rounds }\end{array}$ & $\begin{array}{c}\text { Formation of } \\
\text { Screened interval }\end{array}$ & \begin{tabular}{c} 
Completion \\
\hline Upgradient
\end{tabular} \\
\hline 67 & $89-91$ & & $82.8-102.8$ & Dilworth \\
968 & $89-91$ & 5 & $60-80$ & Dilworth \\
969 & $89-92$ & 5 & $88-108$ & Dilworth \\
979 & $89-92$ & 7 & $69.5-89.5$ & Dilworth \\
Downgradient & & 7 & & \\
833 & 86,91 & & $110-140$ & Dilworth \\
977 & $89-91$ & 2 & $82-85$ & Dilworth \\
\hline
\end{tabular}




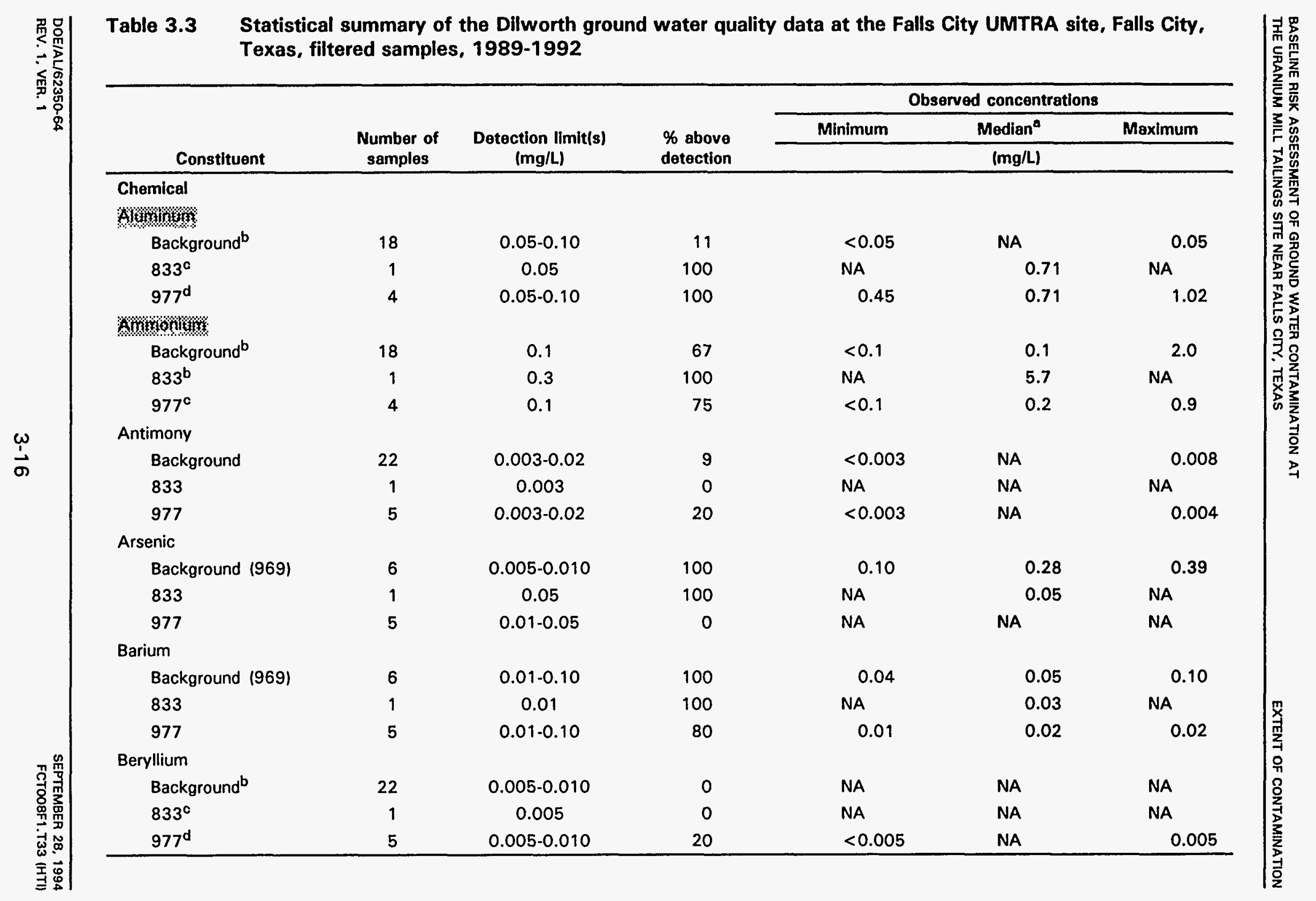




\begin{tabular}{|c|c|c|c|c|c|c|c|}
\hline \multirow{4}{*}{\multicolumn{2}{|c|}{ 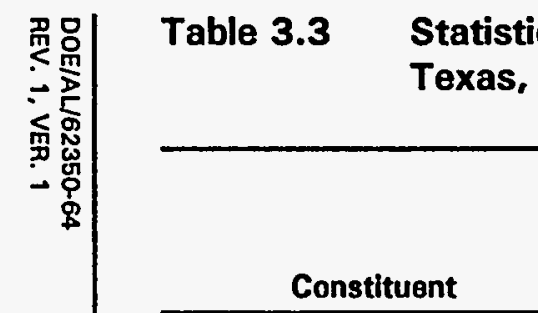 }} & \multirow{4}{*}{$\begin{array}{l}\text { Number of } \\
\text { samples }\end{array}$} & \multirow{4}{*}{$\begin{array}{l}\text { Detection limit(s) } \\
\text { (mg/L) }\end{array}$} & \multirow{4}{*}{$\begin{array}{l}\text { \% above } \\
\text { detection }\end{array}$} & ta at the F & Y UMTRA & Falls City, \\
\hline & & & & & \multicolumn{3}{|c|}{ Observed concentrations } \\
\hline & & & & & Minimum & Modlan" & Maximum \\
\hline & & & & & & (mg/L) & \\
\hline & \multicolumn{7}{|l|}{ Boron } \\
\hline & Background (967) & 4 & $0.05-0.10$ & 100 & 0.88 & 1.03 & 1.10 \\
\hline & 833 & 1 & 0.05 & 100 & NA & 0.85 & NA \\
\hline & 977 & 4 & $0.05-0.10$ & 100 & 0.72 & 0.83 & 0.98 \\
\hline & \multicolumn{7}{|l|}{ Bromide } \\
\hline & Background (969) & 5 & 0.10 & 100 & 2.6 & 3.2 & 5.8 \\
\hline & 833 & 1 & 1.0 & 100 & NA & 1.0 & NA \\
\hline & 977 & 4 & 0.10 & 100 & 1.7 & 1.8 & 2.1 \\
\hline & \multicolumn{7}{|l|}{ CAnmiarit } \\
\hline & Background & 22 & 0.001 & 27 & $<0.001$ & NA & 0.005 \\
\hline & 833 & 1 & 0.001 & 0 & NA & NA & NA \\
\hline & 977 & 5 & $0.001-0.010$ & 100 & 0.013 & 0.020 & 0.022 \\
\hline & \multicolumn{7}{|l|}{ Calcium } \\
\hline & Background (969) & 6 & $0.01-2.00$ & 100 & 481 & 502 & 560 \\
\hline & 833 & 1 & 0.5 & 100 & NA & 367 & NA \\
\hline & 977 & 5 & $0.01-0.5$ & 100 & 188 & 242 & 282 \\
\hline & \multicolumn{7}{|l|}{ Chloride } \\
\hline & $\begin{array}{l}\text { Background b } \\
(967,969)\end{array}$ & 11 & 1.0 & 100 & 680 & 793 & 1020 \\
\hline & $833^{c}$ & 1 & 4.0 & 100 & NA & 472 & NA \\
\hline & $977^{d}$ & 5 & $0.5-1.0$ & 100 & 280 & 374 & 553 \\
\hline & \multicolumn{7}{|l|}{ Chromium } \\
\hline 䝉 & Background & 22 & 0.01 & 18 & $<0.01$ & NA & 0.02 \\
\hline 㸚 & 833 & 1 & 0.01 & 0 & NA & NA & NA \\
\hline$-1 \vec{\omega} \tilde{\infty}$ & 977 & 5 & 0.01 & 20 & $<0.01$ & NA & 0.01 \\
\hline
\end{tabular}




\begin{tabular}{|c|c|c|c|c|c|c|c|c|}
\hline \multirow{13}{*}{ 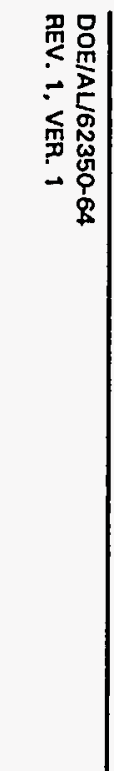 } & $\begin{array}{l}\text { Statist } \\
\text { Texas, }\end{array}$ & \multicolumn{6}{|c|}{$\begin{array}{l}\text { Statistical summary of the Dilworth ground water quality data at the Falls City UMTRA site, Falls City, } \\
\text { Texas, filtered samples, } 1989-1992 \text { (Continued) }\end{array}$} & 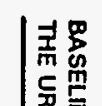 \\
\hline & & & & & \multicolumn{3}{|c|}{ Observed concentrations } & $1 \geq \pi$ \\
\hline & \multirow[b]{2}{*}{ Constituent } & \multirow{2}{*}{$\begin{array}{l}\text { Number of } \\
\text { samples }\end{array}$} & \multirow{2}{*}{$\begin{array}{l}\text { Detection limit(s) } \\
\text { (mg/L) }\end{array}$} & \multirow{2}{*}{$\begin{array}{l}\text { \% above } \\
\text { detection }\end{array}$} & Minimum & Median" & Maximum & \\
\hline & & & & & & (mg/L) & & \\
\hline & 6060 & & & & & & & \\
\hline & Background & 22 & $0.01-0.05$ & 14 & 0.01 & NA & 0.05 & 윽유 \\
\hline & 833 & 1 & 0.03 & 100 & NA & 0.08 & NA & $\sum_{m}^{n} \frac{9}{8}$ \\
\hline & 977 & 5 & $0.03-0.05$ & 100 & 0.06 & 0.08 & 0.09 & 焉害 \\
\hline & Copper & & & & & & & \\
\hline & Background & 22 & $0.01-0.02$ & 18 & $<0.01$ & NA & 0.06 & \\
\hline & 833 & 1 & 0.01 & 0 & NA & NA & NA & \\
\hline & 977 & 5 & $0.01-0.02$ & 40 & $<0.01$ & NA & 0.03 & 牙年 \\
\hline & Cyanide & & & & & & & \\
\hline \multirow{12}{*}{$\stackrel{\omega}{\infty}$} & Background & 20 & 0.01 & 10 & $<0.01$ & NA & 0.02 & $\frac{21}{0}$ \\
\hline & 833 & 0 & NA & NA & NA & NA & NA & 2 \\
\hline & 977 & 5 & 0.01 & 20 & $<0.01$ & NA & 0.01 & \\
\hline & Wortw & & & & & & & \\
\hline & Background $^{b}$ (979) & 5 & 0.1 & 100 & 0.4 & 0.4 & 0.5 & \\
\hline & $833^{c}$ & 1 & 0.1 & 100 & NA & 1.0 & NA & \\
\hline & $977^{d}$ & 4 & 0.1 & 25 & $<0.1$ & NA & 0.2 & \\
\hline & not & & & & & & & \\
\hline & Background (969) & 6 & $0.02-0.03$ & 100 & 0.24 & 0.78 & 2.70 & \\
\hline & 833 & 1 & 0.3 & 100 & NA & 127 & NA & \\
\hline & 977 & 5 & 0.03 & 100 & 0.14 & 0.53 & 1.43 & $\mathrm{x}$ \\
\hline & Lead & & & & & & & III \\
\hline \multirow{3}{*}{ 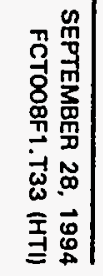 } & Background & 22 & $0.001-0.1$ & 9 & 0.001 & NA & 0.002 & 유 \\
\hline & 833 & 1 & 0.005 & 0 & NA & NA & NA & $\overbrace{2}^{0}$ \\
\hline & 977 & 5 & $0.005-0.1$ & 0 & NA & NA & NA & $\mid \begin{array}{l}-1 \\
3\end{array}$ \\
\hline
\end{tabular}




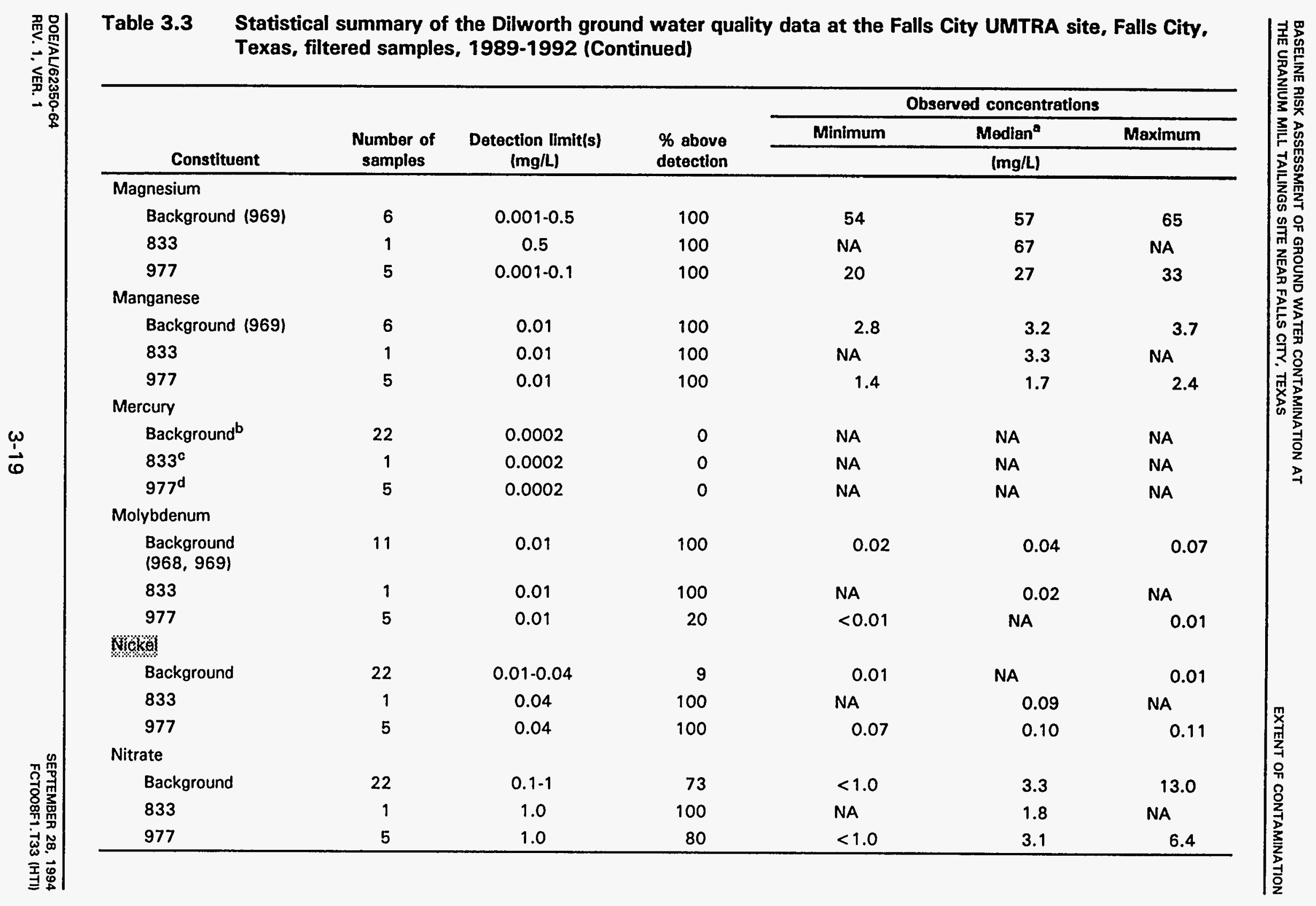




\begin{tabular}{|c|c|c|c|c|c|c|c|}
\hline \multirow{4}{*}{ 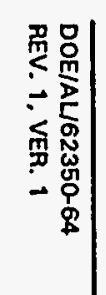 } & $\begin{array}{l}\text { Statisti } \\
\text { Texas, }\end{array}$ & $\begin{array}{l}\text { summary of } \\
\text { ared sample }\end{array}$ & $\begin{array}{l}\text { the Dilworth grol } \\
1989-1992 \text { (Co }\end{array}$ & $\begin{array}{l}\text { water que } \\
\text { nued) }\end{array}$ & at the & UMI KB & alls City, \\
\hline & & \multirow{3}{*}{$\begin{array}{c}\text { Number of } \\
\text { samples }\end{array}$} & \multirow{3}{*}{$\begin{array}{c}\text { Detection limit(s) } \\
\text { (mg/L) }\end{array}$} & \multirow{3}{*}{$\begin{array}{l}\text { \% above } \\
\text { detection }\end{array}$} & \multicolumn{3}{|c|}{ Observed concentrations } \\
\hline & \multirow[b]{2}{*}{ Constituent } & & & & Minimum & Median ${ }^{a}$ & Maximum \\
\hline & & & & & & (mg/L) & \\
\hline & \multicolumn{7}{|l|}{ Phosphate } \\
\hline & Background & 18 & $0.1-1$ & 89 & 0.3 & 0.5 & 1.1 \\
\hline & 833 & 1 & 0.1 & 100 & NA & 0.5 & NA \\
\hline & 977 & 4 & 0.1 & 75 & $<0.1$ & 0.2 & 0.2 \\
\hline & \multicolumn{7}{|l|}{ Potassium } \\
\hline & Background $^{\mathrm{b}}$ (969) & 6 & $0.01-5$ & 100 & 37 & 42 & 44 \\
\hline & $833^{c}$ & 1 & 5 & 100 & NA & 44 & NA \\
\hline & $977^{d}$ & 5 & $0.01-5$ & 100 & 24 & 30 & 37 \\
\hline & \multicolumn{7}{|l|}{ Selenium } \\
\hline & Background & 22 & $0.002-0.03$ & 36 & 0.002 & NA & 0.024 \\
\hline & 833 & 1 & 0.005 & 0 & NA & NA & NA \\
\hline & 977 & 5 & $0.005-0.03$ & 20 & $<0.005$ & NA & 0.007 \\
\hline & \multicolumn{7}{|l|}{ Silica } \\
\hline & Background (968) & 4 & $0.1-2$ & 100 & 88 & 91 & 100 \\
\hline & 833 & 1 & 0.1 & 100 & NA & 45 & NA \\
\hline & 977 & 4 & $0.1-2$ & 100 & 88 & 102 & 121 \\
\hline & \multicolumn{7}{|l|}{ Silver } \\
\hline & Background & 22 & 0.01 & 5 & $<0.01$ & NA & 0.02 \\
\hline & 833 & 1 & 0.01 & 0 & NA & NA & NA \\
\hline & 977 & 5 & 0.01 & 0 & NA & NA & NA \\
\hline & \multicolumn{7}{|l|}{ Sodium } \\
\hline 总兽 & $\begin{array}{l}\text { Background } \\
(967,969)\end{array}$ & 11 & $0.002-5$ & 100 & 482 & 550 & 675 \\
\hline 总勇 & 833 & 1 & 5 & 100 & NA & 604 & NA \\
\hline$\dot{\vec{\omega}} \tilde{\omega}$ & 977 & 5 & $0.002-5$ & 100 & 412 & 484 & 520 \\
\hline
\end{tabular}




\begin{tabular}{|c|c|c|c|c|c|c|c|c|}
\hline \multirow{13}{*}{ 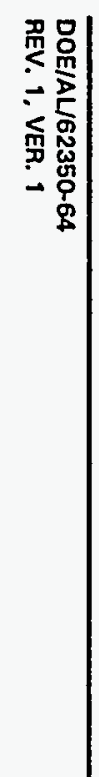 } & $\begin{array}{l}\text { Statisti } \\
\text { Texas, }\end{array}$ & $\begin{array}{l}\text { ummary of } \\
\text { red sample }\end{array}$ & $\begin{array}{l}\text { the Dilworth gro } \\
1989-1992 \text { (C }\end{array}$ & $\begin{array}{l}\text { water qui } \\
\text { lued) }\end{array}$ & ta at the Fi & Y UMTRA & Falls City, & 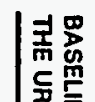 \\
\hline & & \multirow{3}{*}{$\begin{array}{c}\text { Number of } \\
\text { samples }\end{array}$} & \multirow{3}{*}{$\begin{array}{c}\text { Detection limit(s) } \\
\text { (mg/L) }\end{array}$} & \multirow{3}{*}{$\begin{array}{l}\text { \% above } \\
\text { detection }\end{array}$} & \multicolumn{3}{|c|}{ Observed concentrations } & \\
\hline & \multirow[b]{2}{*}{ Constituent } & & & & Minimum & Modiana & Maximum & \\
\hline & & & & & \multicolumn{3}{|c|}{ (mg/L) } & \\
\hline & \multicolumn{7}{|l|}{ Strontium } & 185 \\
\hline & \multirow{2}{*}{$\begin{array}{l}\text { Background }(979) \\
833^{c}\end{array}$} & 5 & $0.01-0.1$ & 100 & 1.5 & 1.8 & 77 & 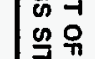 \\
\hline & & 1 & 0.01 & 100 & NA & 3.3 & NA & \\
\hline & \multirow{2}{*}{$\begin{array}{l}977^{d} \\
\text { Sifforatie }\end{array}$} & 4 & $0.01-0.1$ & 100 & 1.7 & 2.3 & 2.6 & 覂足 \\
\hline & & & & & & & & \\
\hline & Background (969) & 6 & $0.1-10$ & 100 & 1220 & 1300 & 1440 & \\
\hline & 833 & 1 & 10 & 100 & NA & 1930 & NA & \\
\hline & \multirow{2}{*}{$\begin{array}{l}977 \\
\text { Sulfide }\end{array}$} & 5 & $0.1-10$ & 100 & 1160 & 1320 & 1580 & \\
\hline & & & & & & & & \\
\hline \multirow{12}{*}{ ú } & Background & 20 & $0.1-1$ & 30 & $<0.1$ & NA & 55 & \\
\hline & 833 & 0 & NA & NA & NA & NA & NA & $z$ \\
\hline & \multirow{2}{*}{$\begin{array}{r}977 \\
\text { Thallium }\end{array}$} & 5 & $0.1-1$ & 0 & NA & NA & NA & \\
\hline & & & & & & & & \\
\hline & Background & 22 & $0.01-0.1$ & 5 & $<0.01$ & NA & 0.1 & \\
\hline & 833 & 1 & 0.05 & 0 & NA & NA & NA & \\
\hline & $\operatorname{Tin}^{977}$ & 5 & $0.01-0.1$ & 0 & NA & NA & NA & \\
\hline & Tin & & & & & & & \\
\hline & Background & 22 & $0.005-0.05$ & 23 & $<0.005$ & NA & 0.019 & \\
\hline & 833 & 1 & 0.1 & 0 & NA & NA & NA & \\
\hline & 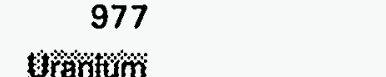 & 5 & $0.005-0.05$ & 40 & 0.01 & NA & 0.02 & $\mathbf{m}$ \\
\hline & yortom & & & & & & & $\frac{\text { min }}{2}$ \\
\hline \multirow{3}{*}{ 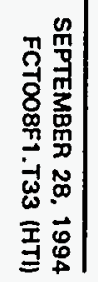 } & Background $d^{b}$ (968) & 5 & $0.001-0.003$ & 100 & 0.026 & 0.056 & 0.068 & ồ \\
\hline & $833^{c}$ & 1 & 0.0001 & 100 & NA & 3.04 & NA & $\overbrace{2}^{8}$ \\
\hline & $977^{d}$ & 5 & $0.001-0.003$ & 100 & 0.016 & 0.023 & 0.054 & 吾 \\
\hline
\end{tabular}




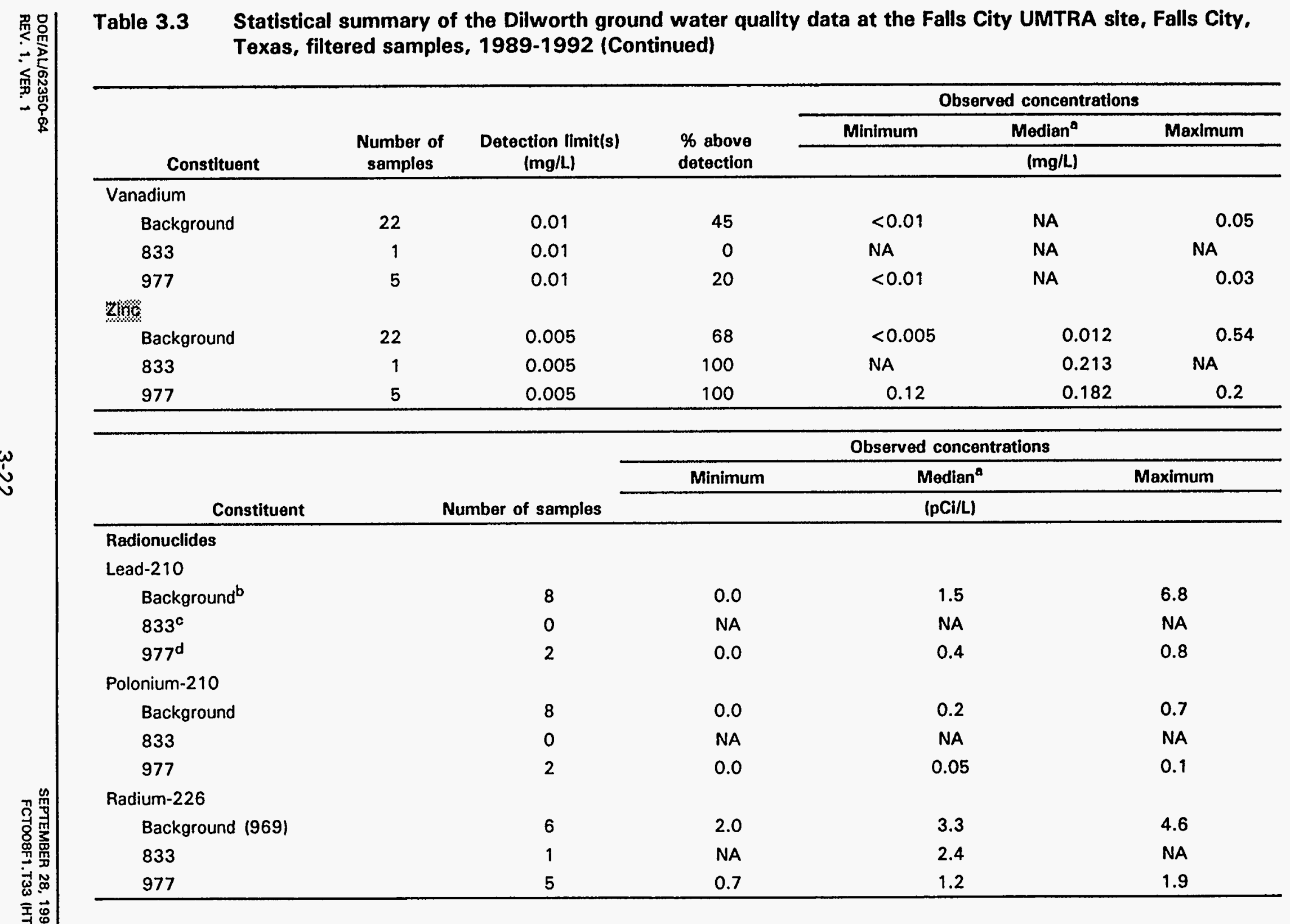


Table 3.3 Statistical summary of the Dilworth ground water quality data at the Falls City UMTRA site, Falls City, Texas, filtered samples, 1989-1992 (Concluded)

\begin{tabular}{|c|c|c|c|c|}
\hline \multirow[b]{3}{*}{ Constituent } & \multirow[b]{3}{*}{ Number of samples } & \multicolumn{3}{|c|}{ Observed concentrations } \\
\hline & & Minimum & Median & Maximum \\
\hline & & & $(\mathrm{pCl} / \mathrm{L})$ & \\
\hline \multicolumn{5}{|l|}{ Thorium-230 } \\
\hline Background & 8 & 0.1 & 0.3 & 0.9 \\
\hline 833 & 0 & NA & NA & NA \\
\hline 977 & 2 & 0.1 & 0.3 & 0.5 \\
\hline
\end{tabular}

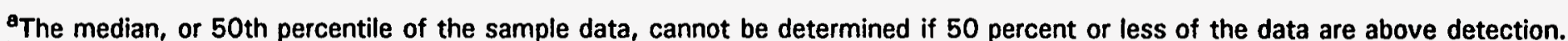

${ }^{b}$ Background represents data pooled from monitor wells $967,968,969$, and 979 unless one or more of these wells have significantly higher levels than the others. In such cases, the background represents the higher levels.

'Monitor well 833 represents the western plume region. Water quality data from one sampling round in December 1991 were used to determine constituents of concern for this plume region.

${ }^{d}$ Monitor well 977 represents the eastern plume region. Water quality data from 1989 through 1991 were used to determine constituents of concern for the eastern plume region.

Numbers in parentheses are well numbers. Highlighted constituents are elevated in plume wells compared to background.

NA - not applicable. 
manganese in the $2+$ valence state. A greater interaction with calcite is also indicated for the ground water from 969 (it is saturated with respect to calcite) while ground water from the other three background monitor wells is not.

Some trace element concentrations are also elevated in ground water from these background Dilworth monitor wells. Arsenic concentrations as high as 0.39 $\mathrm{mg} / \mathrm{L}$ have been found in monitor well 969 and consistently elevated uranium concentrations (about $0.06 \mathrm{mg} / \mathrm{L}$ ) have been found in ground water from monitor well 968 . Given that 968 and 969 are at least $2000 \mathrm{ft}(600 \mathrm{~m})$ upgradient or crossgradient from the tailings piles, these elevated uranium and arsenic concentrations are not due to the influence of tailings-contaminated ground water.

Arsenic is commonly enriched in uranium ore deposits. A possible explanation for the elevated uranium and arsenic levels in monitor wells 968 and 969 is that they are screened in or near a uranium-mineralized section of the Dilworth. This is supported by the presence of abandoned, open pit uranium mines in the outcrop of the Dilworth near monitor well 969 and approximately $4000 \mathrm{ft}$ $(1200 \mathrm{~m})$ west-northwest of former tailings piles 7 and 1 (DOE, 1992).

Furthermore, Bunker and MacKallor (1973) reported a uranium concentration of approximately $0.1 \mathrm{mg} / \mathrm{L}$ from a domestic (Dilworth) water well sample (premining and milling) from parcel 12 (see Figure 2.7) located downgradient of the Falls City UMTRA site.

\subsection{MAGNITUDE OF SITE-RELATED GROUND WATER CONTAMINATION}

Ground water quality data have been reviewed for the period of 1989 through 1993. A hydrological, geochemical, and statistical analysis of the data indicates widespread tailings-related contamination in the Deweesville/Conquista aquifer and significantly less contamination in the Dilworth aquifer.

\subsubsection{Deweesville/Conquista}

Contamination in the Deweesville/Conquista aquifer generally occurs in four distinct contaminant zones (Figure 3.7). Contaminated ground water from some wells in these zones has relatively high levels of aluminum, arsenic, cadmium, manganese, molybdenum, selenium, sulfate, and uranium. A summary of the range of contaminated ground water quality data in each zone is provided in Table 3.1. These four contaminated zones are described below. The locations of Deweesville/Conquista monitor wells are shown in Figure 3.7.

\section{Eastern contaminated zone}

The eastern contaminated zone originates from tailings pile 3. A lobe of contamination extends approximately $3000 \mathrm{ft}(900 \mathrm{~m})$ north-northeast in ground water beneath Scared Dog Creek. The $\mathrm{pH}$ of contaminated ground water in several monitor wells along Scared Dog creek (e.g., 962, 963, 965, and 966) commonly ranges between 3 and 5 . Monitor well 953 approximately $1200 \mathrm{ft}$ 


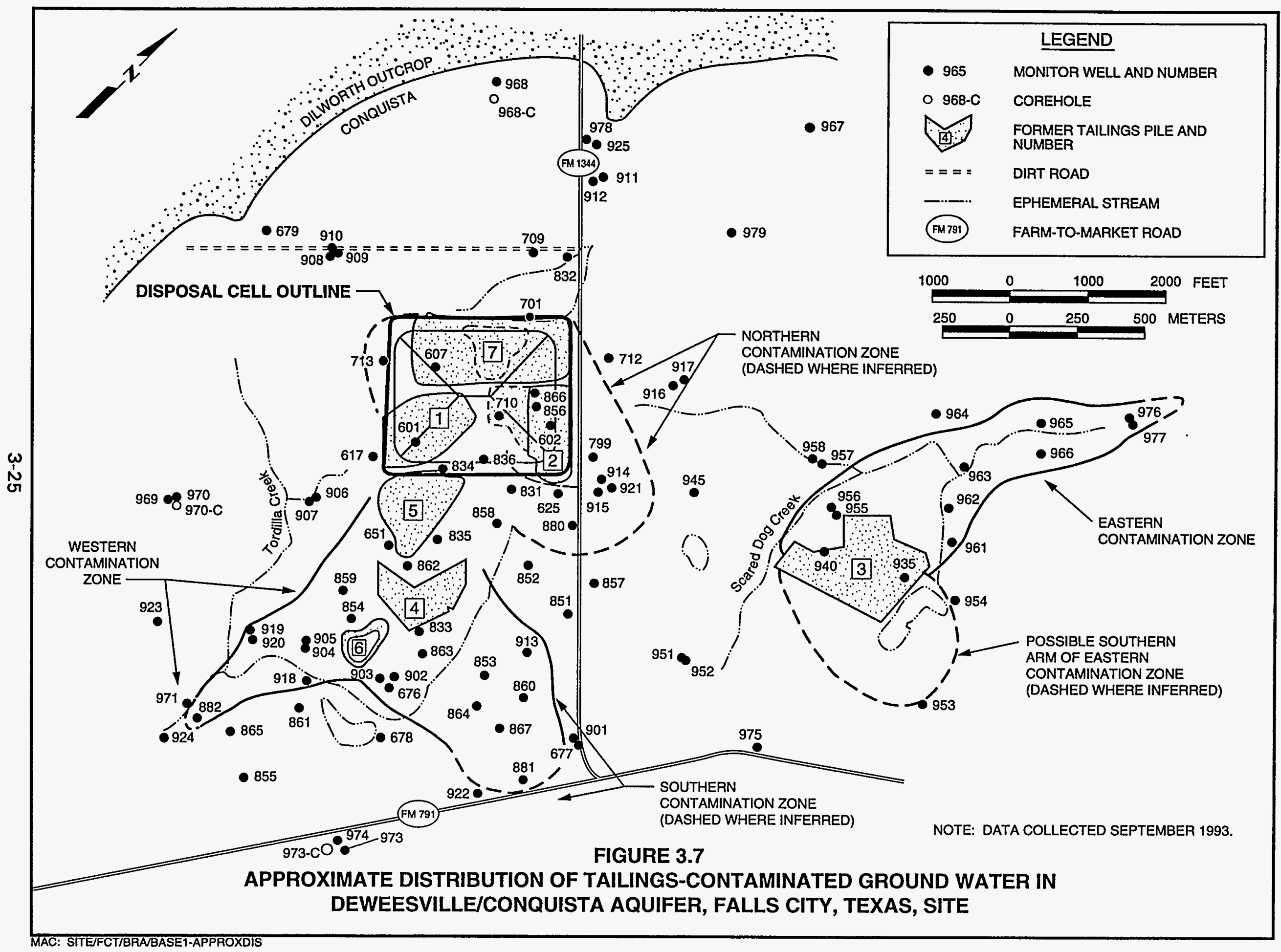


$(3600 \mathrm{~m})$ east-southeast of former tailings pile 3 also shows evidence of tailings-related contamination (low pH). The lack of monitor wells in this zone south of tailings pile 3 precludes a more precise delineation of a possible southeastern lobe of the eastern contaminated zone.

\section{Northern contaminated zone}

The northern contaminated zone is associated primarily with former tailings piles 2 and 7 . The ground water $\mathrm{pH}$ in this zone varies from about 3 in monitor well 625 to almost 7 in well 921 . Locally in this zone, high levels of sulfate contamination (approximately $11,000 \mathrm{mg} / \mathrm{L}$ in monitor well 625) are present.

\section{Southern contaminated zone}

The primary source areas of the southern contaminated zone appear to be former tailings piles 4 and 5 . The southern contaminated zone appears to extend as far as monitor well 881 , approximately $2500 \mathrm{ft}(760 \mathrm{~m})$ southeast of the former processing site. The contaminated zone is generally acidic, with a $\mathrm{pH}$ range from 3 to 4 and significantly higher chloride concentrations than other contaminated zones.

\section{Western contaminated zone}

Most of the western contaminated zone is acidic (e.g., monitor wells 854,882 , and 904). Ground water from monitor well 918 , however, is only slightly acidic (pH of about 5) (DOE, 1992). The western contaminated zone appears to originate from piles 4 and 5 . This contaminated zone extends over $3000 \mathrm{ft}$ $(900 \mathrm{~m})$ southwest in ground water beneath Tordilla Creek.

\subsubsection{Dilworth}

Contamination in the Dilworth aquifer was identified in monitor well 977 , north of former tailings pile 3 , and in former monitor well 833 at the southern edge of pile 4. Monitor well 977 was formerly identified as being completed in the Deweesville/Conquista aquifer (DOE, 1992). However, a review of the boring logs and surface geology suggests this well is actually completed in the Dilworth Sandstone in an area where the Dilworth outcrops along Scared Dog Creek. Ground water sampled from monitor well 977 (sampled June 1991) is acidic (pH 4.23) and contains moderately high levels of aluminum (1.02 mg/L), iron $(1.4 \mathrm{mg} / \mathrm{L})$, sulfate $(1580 \mathrm{mg} / \mathrm{L})$, and uranium $(0.054 \mathrm{mg} / \mathrm{L})$.

Only two sampling rounds (February 1986 and December 1991) were conducted for monitor well 833 before it was abandoned during construction of the disposal cell. The decrease in alkalinity and $\mathrm{pH}$ and the significant increase in concentrations of ammonium, iron, manganese, sulfate, and uranium in the ground water from this well over time (DOE, 1992) suggest the Dilworth is being contaminated in this area. Installation of new monitor wells at locations 
beneath the former tailings piles is needed to verify if the Dilworth has been contaminated by processing site activities.

Filtered ground water quality data from monitor well 977 (from 1989 through 1992) and monitor well 877 (1991 data) were used to determine site related contaminants of potential concern in the eastern and western portions of the Dilworth aquifer.

For the Dilworth aquifer, a constituent was placed on the list of contaminants of potential concern (Table 3.3, column 1) if the average concentration of the contaminant in downgradient monitor well 977 (representing the eastern contamination zone) or the single measurement of concentration for monitor well 833 (representing the western contamination zone) was significantly higher than the average background concentration. For constituents where adequate numbers of detectable concentrations were avalable to support parametric model assumptions, analysis of variance (ANOVA) was used to compare background and plume concentrations. The ANOVA model included a fixed factor for location (background versus plume) and two random factors to estimate between well and within well variability. An alternative statistical method, the nonparametric Mann-Whitney test, was used to compare background and contamination zone concentrations of constituents with a low frequency of detection. Regardless of statistical method, a 0.10 level of significance was used for each individual test. This level of significance was selected over the more common 0.05 level to enhance the power of the test to detect differences between background and contamination zones, given the small amounts of data available from contamination zone wells.

\subsection{CONTAMINANTS OF POTENTIAL CONCERN}

The data presented in Sections 3.1 and 3.2 were used to compile a list of contaminants of potential concern in assessing human health or environmental risks at the Falls City site.

Because the full range of background water quality data are not available for the Deweesville/Conquista, contaminants of potential concern could not be determined in this baseline risk assessment. However, Deweesville/Conquista ground water quality is qualitatively evaluated in Section 6.0 for potential toxicity based on data presented in Table 3.1 .

Constituents exceeding background for the Dilworth aquifer are shown in column 1 of Table 3.4. These constituents were screened for their potential to affect human health, using the criteria discussed below, in order to develop a final list of contaminants of potential concern for human health. Because ecological impacts differ from effects on human health, the complete list of contaminants is considered for ecological risk assessment in Section 7.0. 
Table 3.4 Contaminants of potential concern for the Dilworth aquifer, Falls City, Texas, site

\begin{tabular}{cccc}
\hline $\begin{array}{c}\text { Contaminant levels } \\
\text { exceed background }\end{array}$ & $\begin{array}{c}\text { Contaminant levels } \\
\text { in nutritional range }\end{array}$ & $\begin{array}{c}\text { Contaminants of low } \\
\text { toxicity and/or high } \\
\text { dietary range }\end{array}$ & $\begin{array}{c}\text { Contaminants of } \\
\text { potential concern }\end{array}$ \\
\hline Aluminum & Zinc & Aluminum & Cadmium \\
Ammonium & & Ammonium & Cobalt \\
Cadmium & & & Fluoride \\
Cobalt & & Iron \\
Fluoride & & Nickel \\
Iron & & Sulfate \\
Nickel & & Uranium \\
Sulfate & & \\
Uranium & & \\
Zinc & & \\
\hline
\end{tabular}

aScreening process has started with the first column; constituents listed in the second and third columns were subtracted from the list of constituents in the first column; the remaining constituents form the list shown in the last column.

Although zinc was detected above background, it was eliminated as a contaminant of potential concern because it is an essential nutrient and the levels at which it is observed (maximum observed concentration of $0.5 \mathrm{mg} / \mathrm{L}$ ) are in nutritional ranges even when added to expected dietary intake. The recommended daily allowance (RDA) levels range from 5 to $19 \mathrm{mg}$ per day (National Research Council, 1989).

Ammonium and aluminum were eliminated as contaminants of potential concern based on low toxicity at a relatively high normal dietary intake relative to observed levels. Although ammonium is not considered as a dietary component, it is produced in the human body at levels exceeding $4000 \mathrm{mg}$ per day (Summerskill and Wolpert, 1970), roughly 2 orders of magnitude more than would result from ingestion of the most ammonium-contaminated water at the site $(5.7 \mathrm{mg} / \mathrm{L})$. Although this level is higher than background, it is not likely to be associated with adverse health effects.

Screening based on the criteria described above eliminated all of the contaminants from consideration except cadmium, cobalt, fluoride, iron, nickel, sulfate, and uranium. These constituents form the basis of the risk assessment for the Dilworth aquifer at the Falls City site.

\subsection{CONTAMINANT FATE AND TRANSPORT}

The.chemical species present in aqueous systems are a function of $\mathrm{pH}$, Eh, and the concentrations of different anions and cations. Speciation determines the mobility of the chemicals and might also influence their toxicity. Using the geochemical model MINTEQA2, the predominant species of the contaminants of 
concern for human health were predicted (Allison et al., 1991). The contaminants of concern are cadmium, cobalt, fluoride, iron, nickel, sulfate, and uranium. The dominant solution species for the contaminants of concern are listed in Table 3.5.

Constituents in the contaminated zone waters will be subject to dilution and different chemical reactions including oxidation/reduction reactions, precipitation and coprecipitation reactions, adsorption onto aquifer mineral surfaces, and possibly reactions with biologic organisms. The concentrations of the dominantly cationic metals and the major cations calcium, magnesium, potassium, and sodium will be controlled by dilution, precipitation reactions, and sorption reactions. Chloride concentrations will be affected only by dilution or evaporation. Attenuation mechanisms that should control the concentrations of the contaminants of concern for the Falls City site are discussed below.

\section{Cadmium}

Cadmium will be removed rapidly by the precipitation of otavite $\left(\mathrm{CdCO}_{3}\right)$ and hydrolysis reactions as the low pH of the tailings leachate is neutralized by alkaline ground water and the calcite in the aquifer matrix. Dilution with background water will produce cadmium concentrations below detection limits in downgradient ground water. Elevated levels of cadmium are restricted to the areas underneath or immediately adjacent to the tailings pile.

\section{Fluoride}

Fluoride forms a relatively insoluble mineral, fluorite (calcium fluoride). However, both contaminated and background waters are below fluorite saturation by a factor of 10 or more. Thus, fluoride will be transported in the contaminated ground water and will decrease from slightly higher than background ( $1 \mathrm{mg} / \mathrm{L}$ in monitor well 833 ) to background levels (about $0.3 \mathrm{mg} / \mathrm{L}$ ) in response to dilution.

\section{Iron, nickel, and cobalt}

Aqueous species of iron typically are not stable in ground water that is oxidizing and has a $\mathrm{pH}$ near or above 6 . Dissolved iron in oxidizing water with a $\mathrm{pH}$ of 7 should be rapidly oxidized and removed as iron oxyhydroxides. Iron, however, is far more soluble under neutral pH conditions if the ground water is reducing enough to stabilize iron in its +2 oxidation state. Ground water from Dilworth background well 969 historically has had a pH between 6.5 and 7.0. Nonetheless, iron concentrations in these ground waters are well above the values present in the other Dilworth background wells at the site due to more reducing conditions in this well. Thus, iron will be removed from solution under oxidizing conditions near the outcrop (as in monitor well 977) as $\mathrm{pH}$ increases in response to reactions with alkaline waters and calcite in the aquifer matrix. In contrast, iron may persist in areas of reducing conditions, such as in monitor well 833. 
Table 3.5 Chemical speciation

\begin{tabular}{|c|c|c|c|}
\hline Contaminant & Common name & $\begin{array}{c}\text { Species in } \\
\text { Dilworth } \\
\text { ground water }\end{array}$ & Molar \% \\
\hline \multirow[t]{7}{*}{ Cadmium } & Cadmium & $\mathrm{Cd}^{2+}$ & 36 \\
\hline & Cadmium chloride & $\mathrm{CdCl}^{+}$ & 31 \\
\hline & Cadmium sulfate & $\mathrm{CdSO}_{4} \mathrm{AO}$ & 16 \\
\hline & Cadmium bicarbonate & $\mathrm{CdHCO}_{3}+$ & 10 \\
\hline & Cadmium carbonate & $\mathrm{CdCO}_{3} \mathrm{AQ}$ & 3 \\
\hline & Cadmium chloride & $\mathrm{CdCl}_{2} \mathrm{AQ}$ & 2 \\
\hline & Cadmium sulfate & $\mathrm{Cd}\left(\mathrm{SO}_{4}\right)_{2}^{2-}$ & 2 \\
\hline Cobalt ${ }^{a}$ & Cobalt & $\mathrm{Co}^{+} 2$ & 100 \\
\hline \multirow[t]{4}{*}{ Fluoride } & Fluoride & $F^{+}$ & 18 \\
\hline & & $A 1 F^{2+}$ & 12 \\
\hline & & $\mathrm{A} 2 \mathrm{~F}^{+}$ & 58 \\
\hline & & $\mathrm{A} 2 \mathrm{~F}^{2} 3^{\circ}$ & 93 \\
\hline \multirow[t]{2}{*}{ Iron } & Ferrous iron & $\mathrm{Fe}^{2+}$ & 78 \\
\hline & Ferrous sulfate & $\mathrm{FeSO}_{4} \mathrm{AO}$ & 22 \\
\hline \multirow[t]{4}{*}{ Nickel } & Nickel carbonate & $\mathrm{NiCO}_{3} \mathrm{AO}$ & 60 \\
\hline & Nickel & $\mathrm{Ni}^{2+}$ & 25 \\
\hline & Nickel bicarbonate & $\mathrm{NiHCO}_{3}+$ & 8 \\
\hline & Nickel silicate & $\mathrm{NiSO}_{4} \mathrm{AO}$ & 7 \\
\hline \multirow[t]{4}{*}{ Sulfate } & Sulfate & $\mathrm{SO}_{4}^{2-}$ & 69 \\
\hline & Calcium sulfate & $\mathrm{CaSO}_{4} \mathrm{AO}$ & 24 \\
\hline & Magnesium sulfate & $\mathrm{MgSO}_{4} \mathrm{AO}$ & 4 \\
\hline & Sodium sulfate & $\mathrm{NaSO}_{4}^{-}$ & 3 \\
\hline \multirow[t]{4}{*}{ Uranium } & Uranyl dicarbonate & $\mathrm{UO}_{2}\left(\mathrm{CO}_{3}\right)_{2}^{2-}$ & 55 \\
\hline & Uranyl hypophosphate & $\mathrm{UO}_{2}\left(\mathrm{HPO}_{4}\right)_{2}^{2-}$ & 23 \\
\hline & Uranyl tricarbonate & $\mathrm{UO}_{2}\left(\mathrm{CO}_{3}\right)_{3}^{4-}$ & 18 \\
\hline & Uranyl carbonate & $\mathrm{UO}_{2} \mathrm{CO}_{3} \mathrm{AO}$ & 4 \\
\hline
\end{tabular}

${ }^{a} \mathrm{Co}^{2+}$ is the predominant species. Other species and inorganic complexes are similar to those of $\mathrm{Ni}^{2+}$.

$A Q$ - noncharged aqueous species. 
Elevated levels of nickel and cobalt might have been introduced to the Dilworth aquifer by acidic tailings leachate. Because of their chemical similarity to iron, however, nickel and cobalt are typically coprecipitated during the precipitation of iron hydroxides. At the typical pH range $(6$ to 8$)$ observed for ground water in the Dilworth aquifer at the Falls City site, both nickel and cobalt should be present at levels below or near the detection limit. Slightly elevated levels (e.g., up to $0.05 \mathrm{mg} / \mathrm{L}$ in monitor well 969 ) of cobalt (along with iron) could be expected in naturally reducing, alkaline, background Dilworth ground waters. More elevated cobalt concentrations can occur in low-pH contaminated ground waters (up to $0.09 \mathrm{mg} / \mathrm{L}$ in acidic Dilworth monitor well 977). When the $\mathrm{pH}$ of this oxidizing water increases to above 5.5, cobalt and nickel concentrations should decrease due to coprecipitation with iron oxyhydroxides and sorption.

\section{Sulfate}

Sulfate concentrations in the contaminated zones of the aquifer immediately adjacent to the processing site are controlled primarily by gypsum solubility. Farther downgradient, sulfate will decrease due to physical processes such as dispersion and dilution. Reduction of sulfate to sulfide is also possible if the contaminated zone interacts with reducing sediment or ground water in the presence of organic carbon.

Adsorption reactions are not likely to have a significant effect on the sulfate concentrations in the shallow ground water because of the high concentrations involved. Given the high redox potential of the shallow ground water in the Deweesville/Conquista and Dilworth aquifers, sulfate removal by reduction to sulfide is unlikely to occur.

\section{Uranium}

Uranium is mobile in acidic ground water (e.g., $\mathrm{pH}$ is 3 to 4) where it typically will exist as positively charged uranyl, uranium hydroxyl, and (in high sulfate systems) uranium sulfate complexes. In oxidizing, alkaline ground water over a range of elevated $\mathrm{pH}$ values (e.g., between 6.5 and 8.5), uranium can form stable anionic carbonate complexes that facilitate uranium transport in ground water.

Uranium is present at elevated levels in both acidic and alkaline ground water at the Falls City site. In both these environments, uranium concentrations will be reduced mainly by adsorption onto aquifer materials and by dilution with uncontaminated ground water. Reduction and precipitation of uranium minerals is unlikely to control uranium concentrations at this site, given the oxidizing conditions of the ground water. 


\subsection{EXPOSURE ASSESSMENT}

Two hydrologic units at the Falls City former uranium processing site are of concern for this risk assessment: the Deweesville/Conquista and the Dilworth aquifers. Due to the limited premilling background ground water quality data for the Deweesville/Conquista and its limited use as a source of domestic or stock water, a qualitative discussion of anticipated adverse health effects from the potential future uses of the Deweesville/ Conquista ground water at the former uranium processing site is provided in Section 6.0, Human Health Risk Evaluation.

This section discusses and quantifies the potential exposures that could be incurred by the current or future residents, or others who use Dilworth ground water contaminated by the Falls City uranium processing site. The methodology used in this assessment is consistent with the latest EPA guidance on exposure assessments (EPA, 1989a), which recommends an analysis based upon the reasonable maximum exposure under both current and potential future land-use conditions. The reasonable maximum exposure is defined as the highest exposure that can be reasonably expected to occur at the site.

\subsection{POTENTIALLY EXPOSED POPULATION}

Exposure can occur only if there are both a source of contamination and a mechanism of transport to a receptor population or an individual. The Dilworth aquifer is not known to be used as a drinking water supply within a 2-mi $(3-\mathrm{km})$ radius of the Falls City site. However, it may be used by the area residents to water livestock or gardens. Using these livestock for food would create an exposure pathway to humans. Plants irrigated with water from the Dilworth aquifer could take up and concentrate contaminants, forming a pathway to humans through plant consumption. Finally, in the future, an exposure pathway could be created through drinking and bathing water.

Since there may be potential human receptors of contaminated ground water, a current and future ground water use scenario is assumed. This scenario evaluates domestic use of contaminated Dilworth ground water consistent with current water use by the farming population in the region. The potentially exposed population includes the following age groups: infants (birth to 1 year old), children (1 to 10 years old), and adults (11 to 65 years old). These age groups were selected because toxicological responses are similar in these age groups, including responsiveness of sensitive subgroups for the contaminants of potential concern (infants and children), consistent intake to body weight ratios, and similar toxicokinetics.

\subsection{EXPOSURE PATHWAYS}

Ground water in the region is primarily used for household purposes such as drinking, cooking, and bathing. Other uses typical of the region that could indirectly lead to human exposure include irrigation and livestock watering. 
As discussed in Section 3.0, natural ground water quality in the Dilworth aquifer is poor, with high sulfate and TDS concentrations. Background upgradient well 969 consistently showed naturally high levels of arsenic, manganese, and sulfate from 1989 to 1994 . This well is presumed to be unaffected by the processing site activity because of its upgradient location. However, this well appears to be completed in the localized uranium mineralized area. Both arsenic and manganese detected at high concentrations in this well typically are associated with the uranium ore deposits found in the Falls City area. Also, high levels of sulfate occur naturally in Dilworth ground water and are associated with gypsum deposits.

Although it is unlikely that the Dilworth ground water will be used in the future for household purposes because of its naturally poor quality and the existing water supply system, this risk assessment assumes hypothetical future use of the Dilworth aquifer ground water for drinking, cooking, and bathing.

Two pathways other than drinking water ingestion exposure evaluated in this assessment of the Dilworth ground water eastern and western contamination zones are meat and milk ingestion from cattle that have consumed ground water, and ingestion of vegetables and fruits irrigated with ground water. Figure 4.1 provides a conceptual model for potential ground water exposure pathways that could result from these uses.

\subsection{EXPOSURE CONCENTRATIONS}

The exposure concentration of a contaminant in ground water is that concentration an individual encounters over a specific period. In this evaluation, the contaminant concentrations in ground water are assumed to be in a steady state, even though actual exposure concentrations are expected to fluctuate and eventually decrease with time because the surface portion of the site has been remediated. Nonetheless, current concentrations are reasonable estimates for chronic exposure soon after remediation. Chronic exposure for noncarcinogens is considered to be any period over 7 years. The lifetime exposure duration for carcinogens is assumed to be $\mathbf{5 0}$ years.

The exposure point concentrations for the Dilworth ground water were determined using maximum well sample results obtained from 1989 to 1992 for the eastern contamination zone location (monitor well 977). The western portion of the contamination zone is represented by a single contaminant measurement (December 1991) from monitor well 833. These exposure point concentrations for the contaminants of potential concern are summarized in Table 4.1. 


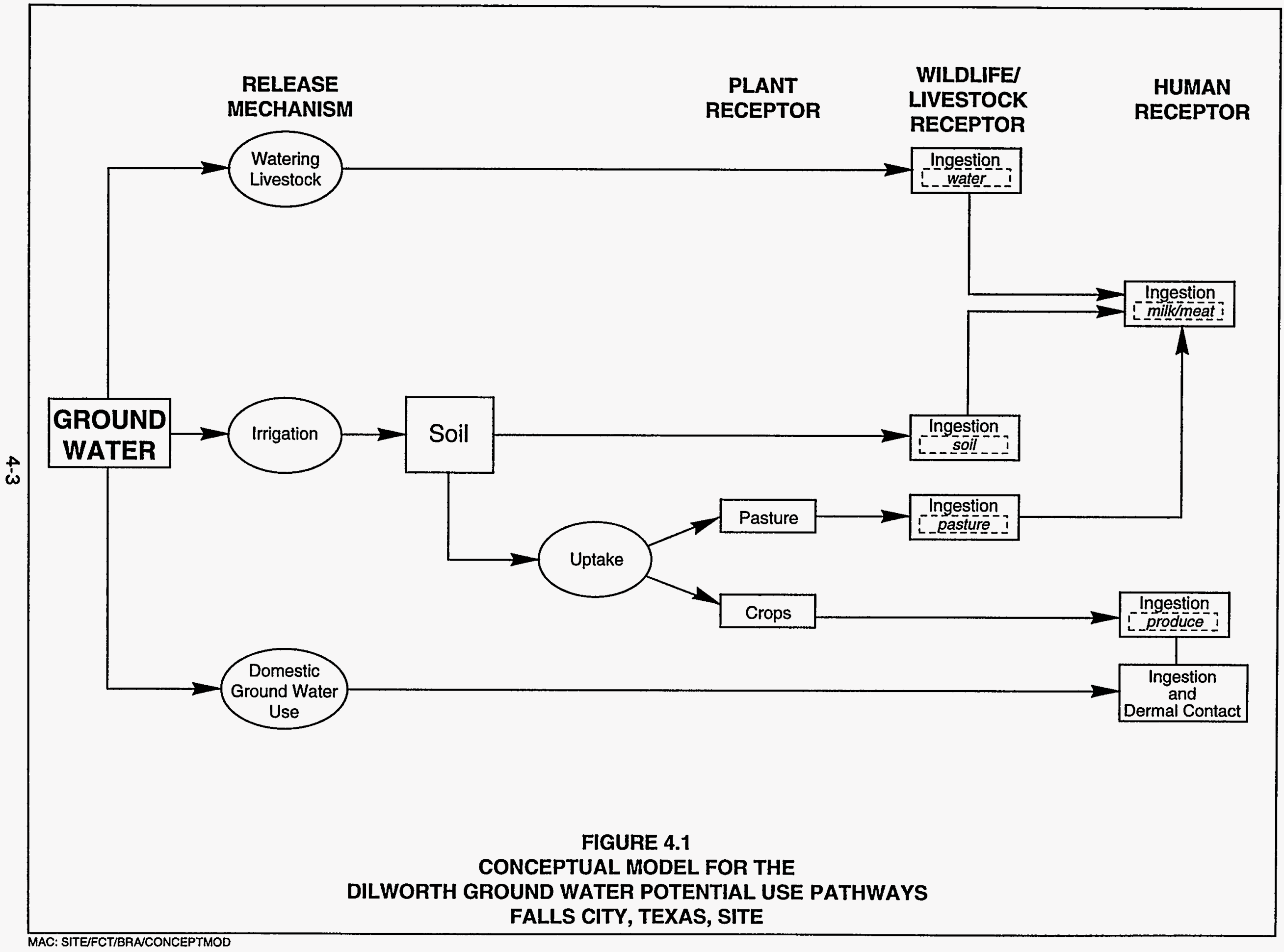


Table 4.1 Exposure concentrations ${ }^{a}$ for the Dilworth ground water potential use, Falls City, Texas, site

\begin{tabular}{cccc}
\hline Contaminant of potential concern & $\begin{array}{c}\text { Eastern contamination } \\
\text { zone }^{\mathbf{b}}\end{array}$ & $\begin{array}{c}\text { Western contamination } \\
\text { zone }^{\mathbf{c}}\end{array}$ \\
\hline Chemicals & Cadmium & 0.022 & ND \\
Cobalt & 0.09 & 0.08 \\
Nickel & 0.11 & 0.09 \\
Fluoride & 0.2 & 1.0 \\
Iron & 1.43 & 127.00 \\
Sulfate & 1305 & 1930 \\
Uranium & 0.054 & 3.04 \\
Radionuclide & & 2085 \\
\hline
\end{tabular}

${ }^{a}$ Concentrations in milligrams per liter.

${ }^{b}$ Exposure concentration is represented by maximum observed concentration in ground water from monitor well 977.

CExposure concentration is represented by a single contaminant measurement in ground water from monitor well 833.

Uranium-234 and uranium-238 combined; 1 milligram uranium is assumed to equal $686 \mathrm{pCi}$; units are picocuries per liter.

ND - not detected.

\subsection{ESTIMATION OF INTAKE}

Individual current and future residents are expected to vary in their water consumption habits, stable body weights, and length of time they reside in the potential contamination zone. Consequently, health risks associated with ground water consumption will also vary among members of the population. Nevertheless, to describe the potential risks to the current and future population, daily water intake, body weight, and residency time were incorporated into this assessment using the default values presented in the standard EPA procedure (EPA, 1989a).

Table 4.2 summarizes the exposure routes and potentially exposed populations that are evaluated quantitatively. Intake is calculated separately for noncarcinogenic and carcinogenic health effects. The potential toxicity of noncarcinogenic contaminants in drinking water depends primarily on long-term (i.e., at least 7 years) average daily consumption of the contaminant per 
kilogram of body weight (measured in milligrams per kilogram per day [mg/kg-day]).

Potential carcinogenicity of radionuclides is thought to increase with total intake over time, instead of with average intake as for noncarcinogens. Also, body weight is relatively insignificant in determining risk from exposure to radionuclides. Carcinogenic intake for radionuclides is therefore quantified as total exposure to radioactivity through the residency period of an individual. A contaminant such as uranium is associated with both noncarcinogenic and carcinogenic effects, so it appears under both carcinogenic and noncarcinogenic intake estimations.

Farming area families near the Falls City site usually reside on their land for most of their entire lives. Because no data exist for length of residence in the site vicinity, a chronic (i.e., at least 7-year) exposure duration is assumed for noncarcinogens, and 50 years is the assumed exposure duration for carcinogens.

Table 4.2 Quantitatively evaluated exposure routes

\begin{tabular}{|c|c|c|c|c|c|}
\hline \multirow[b]{2}{*}{ Source } & \multirow[b]{2}{*}{ Location } & \multirow[b]{2}{*}{ Exposure route } & \multicolumn{3}{|c|}{ Evaluated population } \\
\hline & & & Infant & Child & Adult \\
\hline \multirow{5}{*}{$\begin{array}{l}\text { Dilworth ground } \\
\text { water }\end{array}$} & \multirow{5}{*}{$\begin{array}{l}\text { Eastern and } \\
\text { western } \\
\text { contamination } \\
\text { zones }\end{array}$} & Drinking water ingestion & $x$ & $x$ & $x$ \\
\hline & & Dermal contact (bathing) & & & $x$ \\
\hline & & $\begin{array}{l}\text { Ground water-irrigated } \\
\text { produce ingestion }\end{array}$ & & & $x$ \\
\hline & & Beef ingestion & & & $x$ \\
\hline & & Milk ingestion & & & $x$ \\
\hline
\end{tabular}

\section{Drinking water ingestion}

Drinking water ingestion is generally the most significant exposure route for ground water contaminated with metals and other nonvolatile compounds. For this evaluation, drinking water consumption includes amounts of water consumed for drinking as well as amounts of water used for food preparation (e.g., reconstituted juices, soup, rice, and beans).

The assumptions and equations used to estimate intake from drinking water ingestion are shown in Table 4.3.

\section{Dermal absorption}

Dermal absorption is the process by which chemicals coming into contact with the skin are absorbed into the blood vessels near the surface of the skin. 
Table 4.3 Exposure dose calculations for ingestion of the Dilworth ground water and dermal contact, Falls City, Texas, site

\begin{tabular}{|c|c|c|c|c|c|c|}
\hline \multirow[b]{2}{*}{$\begin{array}{l}\text { Contaminant of } \\
\text { potential concern }\end{array}$} & \multicolumn{3}{|c|}{ Eastern contamination zone } & \multicolumn{3}{|c|}{ Western contamination zone } \\
\hline & Ingestion ${ }^{\mathbf{b}}$ & $\begin{array}{l}\text { Dermal } \\
\text { contact }^{b}\end{array}$ & $\begin{array}{c}\text { Ratio of dermal } \\
\text { contact to } \\
\text { water ingestion }\end{array}$ & Ingestion ${ }^{\mathbf{b}}$ & $\begin{array}{l}\text { Dermal } \\
\text { contact }^{b}\end{array}$ & $\begin{array}{c}\text { Ratio of dermal } \\
\text { contact to water } \\
\text { ingestion }\end{array}$ \\
\hline \multicolumn{7}{|l|}{$\begin{array}{l}\text { Noncarcinogenic } \\
\text { effects }\end{array}$} \\
\hline $\begin{array}{l}\text { Cadmiu } \\
\mathrm{m}\end{array}$ & $6 \mathrm{E}-04$ & $1 E-06$ & 0.002 & - & - & - \\
\hline Cobalt & $3 E-03$ & $5 E-06$ & 0.002 & $2 \mathrm{E}-03$ & $4 E-06$ & 0.002 \\
\hline Fluoride & $\begin{array}{l}6 \mathrm{E}-03 \\
6 \mathrm{E}-03^{\mathrm{C}}\end{array}$ & $1 \mathrm{E}-05$ & 0.002 & $\begin{array}{c}3 \mathrm{E}-02 \\
3 \mathrm{E}-02^{\mathrm{C}}\end{array}$ & $5 E-05$ & 0.002 \\
\hline Iron & $\begin{array}{l}4 \mathrm{E}-02 \\
4 \mathrm{E}-02^{\mathrm{C}}\end{array}$ & $8 \mathrm{E}-05$ & 0.002 & $\begin{array}{l}4 E+00 \\
4 E+00^{C}\end{array}$ & 7E-03 & 0.002 \\
\hline Nickel & $3 E-03$ & $6 \mathrm{E}-06$ & 0.002 & 3E-03 & 5E-06 & 0.002 \\
\hline Sulfate & $\begin{array}{c}4 E+01 \\
2 E+02^{d}\end{array}$ & 7E-02 & 0.002 & $\begin{array}{c}5 E+01 \\
3 E+02^{d}\end{array}$ & 1E-01 & 0.002 \\
\hline Uranium & $2 \mathrm{E}-03$ & $3 E-06$ & 0.002 & $8 \mathrm{E}-02$ & $2 E-04$ & 0.002 \\
\hline \multicolumn{7}{|l|}{ Carcinogenic effects } \\
\hline$e^{\text {Uranium }}$ & $1 E+06^{f}$ & $3 E+03^{f}$ & 0.002 & $7 E+07^{f}$ & $1 E+05^{f}$ & 0.002 \\
\hline
\end{tabular}

a Exposure concentrations are reported in Table 4.1.

bUnits are $\mathrm{mg} / \mathrm{kg}$-day.

CExposure dose calculated for a child aged 1 to 10 years.

dExposure dose calculated for an infant 10 to 1 year).

U Uranium-234 and uranium-238 combined; 1 milligram uranium is assumed to equal $686 \mathrm{pCi}$.

Units are in picocuries per lifetime. 


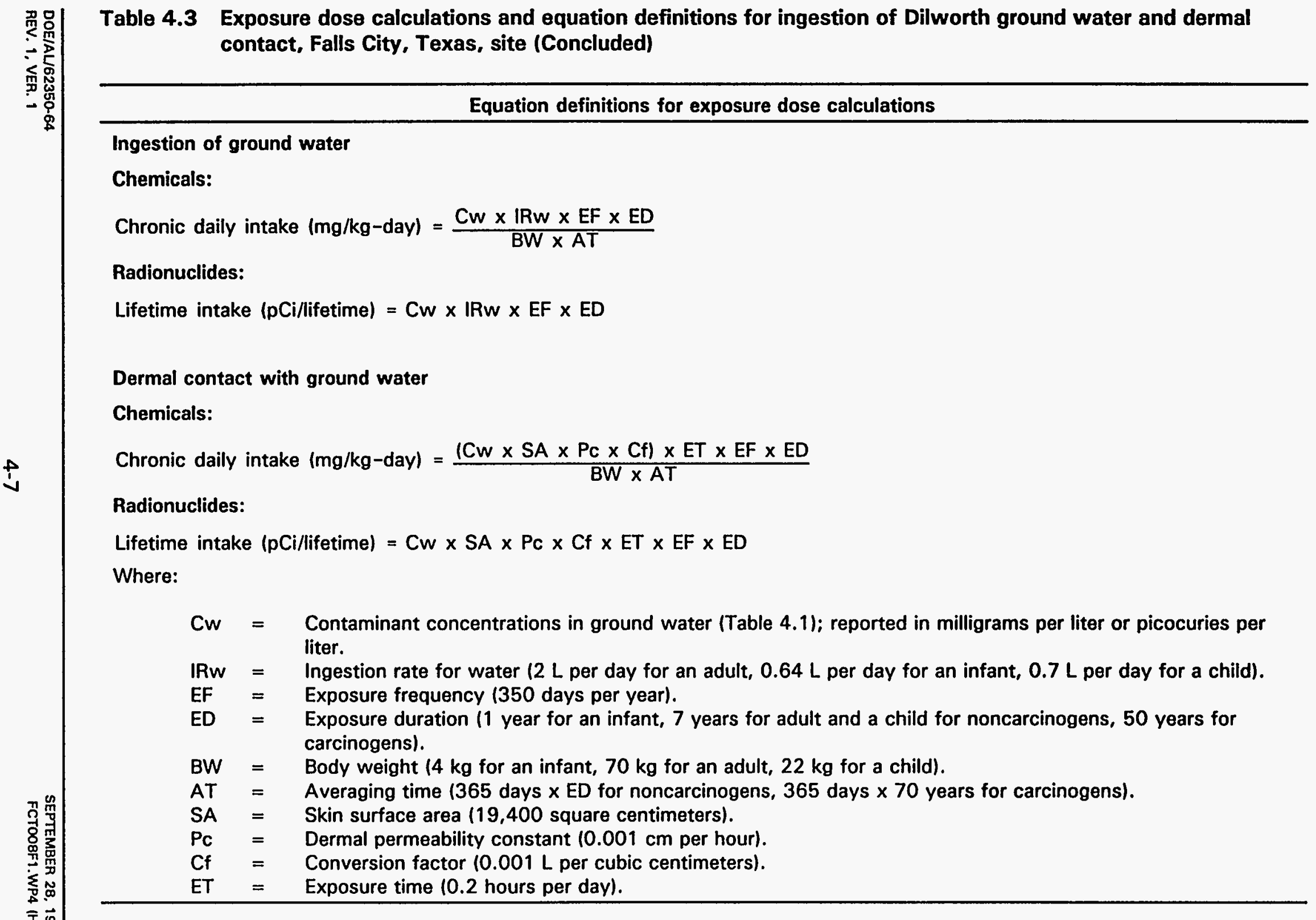


Although some compounds are absorbed easily in this manner, metals are poorly absorbed through intact skin.

To evaluate this exposure route for the contaminants of concern, a screening calculation was performed to determine whether the exposure contribution from dermal absorption would be significant compared to the drinking water route. Since chemical-specific absorption factors are not available for these contaminants, it was assumed that they are absorbed across the skin at the same rate as water. This assumption is likely to overestimate any potential exposure contribution from dermal absorption. The results of the screening are presented in Table 4.3.

Although the dermal dose is an absorbed dose whereas the ingested dose is a total dose of which only some percentage will be absorbed, the very low exposure contribution of dermal absorption, 0.2 percent, is assumed to be insignificant relative to ingestion. Based on these results, the dermal absorption exposure route was eliminated from more detailed evaluation.

\section{Ingestion of ground water-irrigated garden produce}

This exposure route could not be evaluated for relative significance to the drinking water ingestion exposure route. Although the intake from ground water-irrigated produce ingestion is not likely to be greater than the exposure dose from drinking water ingestion, the incremental contribution could be significant because some metals concentrate in plants. There are currently no literature values that could be used to estimate this pathway contribution. However, the UMTRA Ground Water Project is conducting plant uptake studies for irrigated vegetables and grasses. The results of these studies will be included in the National Environmental Policy Act (NEPA) document and ground water compliance strategy planning for this site.

\section{Ingestion of beef and milk from livestock ingesting ground water}

This pathway is considered because livestock are kept on many farms near the site and these livestock may be watered with the Dilworth ground water.

Table 4.4 summarizes the results of the potential human intake of contaminants of potential concern through ingestion of beef and milk from livestock that have consumed contaminated ground water. The calculation of contaminant intake by livestock includes the amount of contaminant that can be bioconcentrated in pasture grasses grown on contaminated soils. However, it does not include the amount bioconcentrated in plants from irrigation water. Because the UMTRA Ground Water Project is conducting plant uptake studies for irrigated grasses, the plant uptake of contaminants from water will be estimated and included in the NEPA document and ground water compliance strategy planning for this site. This exposure route contributed no more than 5 percent of that associated with drinking water ingestion except for cadmium (50 percent), fluoride (about 


\begin{tabular}{|c|c|c|c|c|c|c|c|c|}
\hline \multirow{4}{*}{$\begin{array}{l}\text { Contaminant of } \\
\text { potential } \\
\text { concern }\end{array}$} & \multirow{3}{*}{\multicolumn{2}{|c|}{ Transfer coefficient }} & \multicolumn{6}{|c|}{ Exposure doses $^{b}$} \\
\hline & & & \multicolumn{6}{|c|}{ (mg/kg-day) } \\
\hline & & & \multicolumn{3}{|c|}{ Eastern contamination zone } & \multicolumn{3}{|c|}{ Western contamination zone } \\
\hline & $\mathbf{F b}$ & $\mathbf{F m}$ & Beef & Milk & Total & Beef & Milk & Total \\
\hline \multicolumn{9}{|l|}{ Noncarcinogens } \\
\hline Cadmium & 5.5E-04 & $1 \mathrm{E}-03$ & 4E-05 & $3 E-04$ & $3 E-04$ & $\cdots$ & $\cdots$ & -- \\
\hline Cobalt & $2 \mathrm{E}-02$ & $2 \mathrm{E}-03$ & $9 \mathrm{E}-05$ & $4 \mathrm{E}-05$ & $1 \mathrm{E}-04$ & $8 E-05$ & $3 E-05$ & $1 \mathrm{E}-04$ \\
\hline Fluoride & $1.5 \mathrm{E}-01$ & $1 E-03$ & $1 \mathrm{E}-03$ & $4 \mathrm{E}-05$ & $1 \mathrm{E}-03$ & 7E-03 & $2 E-04$ & 7E-03 \\
\hline Iron & $2 \mathrm{E}-02$ & $2.5 E-04$ & $1 \mathrm{E}-03$ & 7E-05 & $1 \mathrm{E}-03$ & $1 \mathrm{E}-01$ & $6 \mathrm{E}-03$ & $1 \mathrm{E}-01$ \\
\hline Nickel & $6 \mathrm{E}-03$ & $1 \mathrm{E}-03$ & 7E-05 & $5 \mathrm{E}-05$ & $1 \mathrm{E}-04$ & $6 \mathrm{E}-05$ & $4 \mathrm{E}-05$ & $1 \mathrm{E}-04$ \\
\hline Sulfate & $1 \mathrm{E}-01$ & $5 E-03$ & $6 E+00$ & $1 E+00$ & $7 E+00$ & $8 E+00$ & $2 E+00$ & $1 E+01$ \\
\hline Uranium & $2 \mathrm{E}-04$ & $6 E-04$ & 7E-07 & $8 \mathrm{E}-06$ & 9E-06 & $4 \mathrm{E}-05$ & $5 E-04$ & $5 \mathrm{E}-04$ \\
\hline \multicolumn{9}{|l|}{ Carcinogens } \\
\hline Uranium $^{c}$ & $2 E-04$ & $6 E-04$ & $6 E+02^{d}$ & $7 E+03^{d}$ & $8 E+03^{d}$ & $3 E+04^{d}$ & $4 E+05^{d}$ & $4 E+05^{d}$ \\
\hline
\end{tabular}




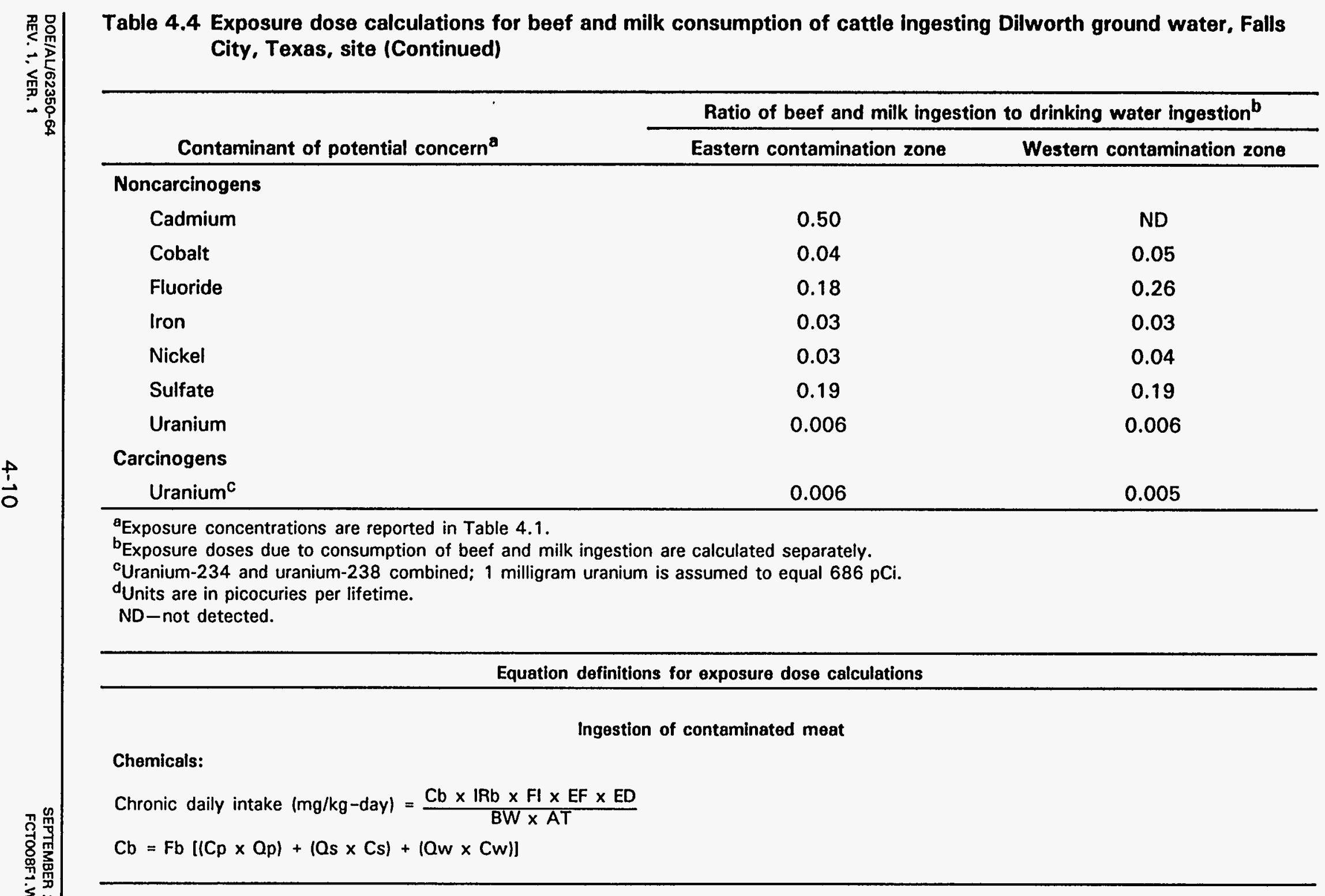

${ }^{a}$ Exposure concentrations are reported in Table 4.1.

Exposure doses due to consumption of beef and milk ingestion are calculated separately.

Uranium-234 and uranium-238 combined; 1 milligram uranium is assumed to equal $686 \mathrm{pC}$

Units are in picocuries per lifetime.

ND-not detected. 


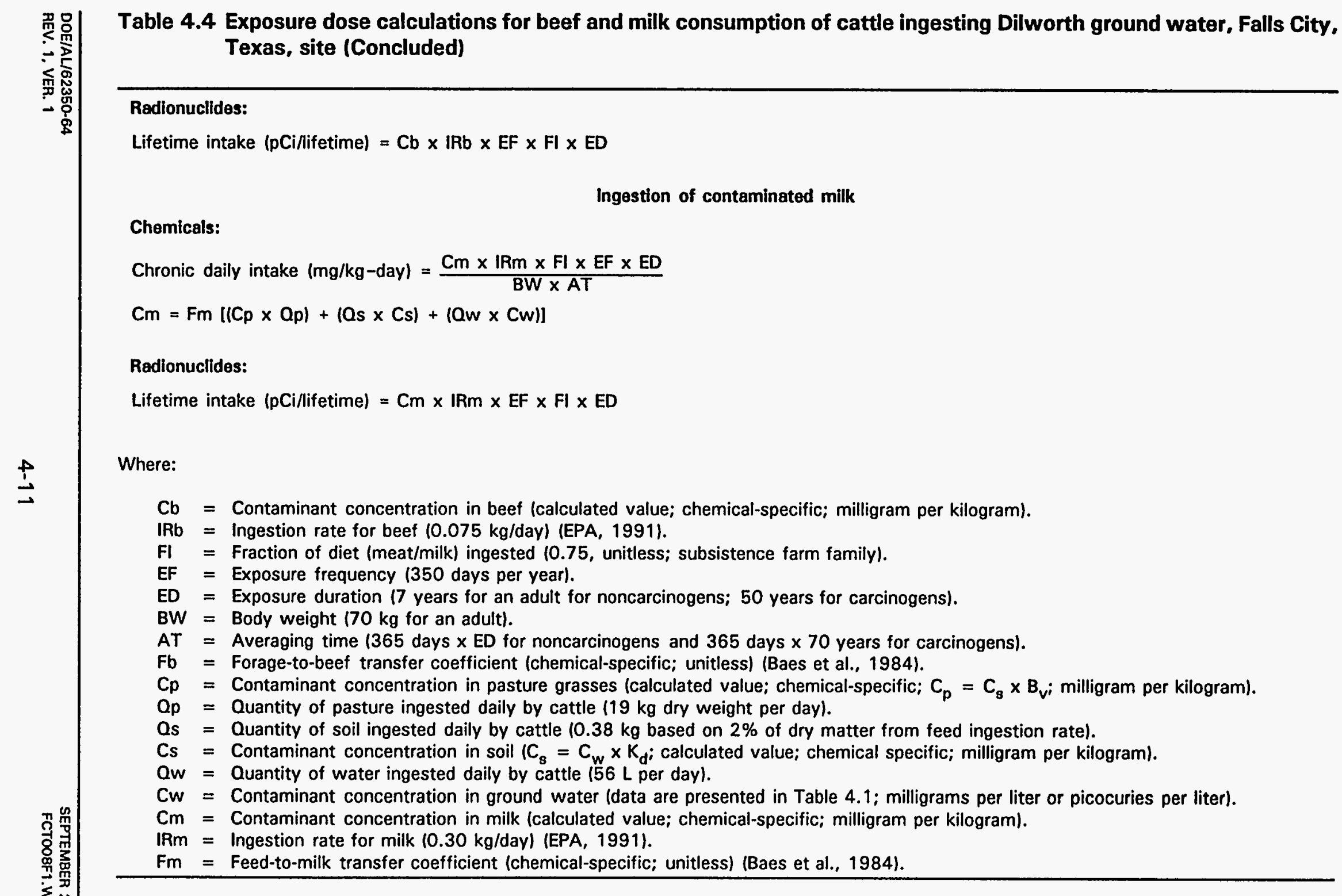


30 percent), and sulfate (approximately 20 percent). Nonetheless, this human exposure pathway is further evaluated in Section 6.1.2.

\subsection{EXPOSURE ASSESSMENT UNCERTAINTIES}

Several potential sources of error may arise in all phases of an exposure assessment, including the following sources of uncertainty:

- Incomplete environmental sampling data (ground water), which could lead to an underestimate or overestimate in the exposure analysis.

- The use of filtered ground water samples. The results of exposure assessment presented in this document are based on filtered 10.45 micrograms $[\mu \mathrm{g}])$ ground water samples. Therefore, the potential loss of certain ground water constituents as a consequence of filtration is associated with an additional source of uncertainty.

- The assumption that the ground water contaminant source term at the site has reached a steady state and that contaminant concentrations at the exposure point will remain constant for chronic periods of exposure (generally greater than 7 years).

- Additivity; the drinking water pathway is considered the major determinant of exposure in this risk assessment. However, the incremental contribution from the ground water-irrigated produce ingestion pathway, that could not be estimated here, could be significant.

- The model used to estimate concentrations of contaminants in meat tissue or milk in the beef and milk consumption pathway. Many factors in this pathway have considerable uncertainties that could affect the estimates by the order of magnitude. For example, contaminant concentrations in pasture grasses, calculated here, do not include plant uptake directly from irrigation water. In addition, under site conditions, plant uptake factors from soil could vary substantially from the default literature estimates. The net effect on exposure estimates of these uncertainties cannot be predicted.

- The relationship between an applied dose (used here) and absorbed or effective dose in calculating dermal absorption. The assumption that metals are absorbed across intact skin at the same rate as water is likely to overestimate any potential contribution of exposure from dermal absorption.

- Different sensitivities of subpopulations such as diabetics and the elderly.

Despite these uncertainties, the intake estimates derived here probably represent reasonable maximum exposures if ground water is used at the site. 


\subsection{TOXICITY ASSESSMENT}

Several contaminants that could adversely affect human health and the environment have been detected in ground water at the site. This section summarizes the potential toxicological effects of the chemical contaminants and the carcinogenic potentials of the radionuclides.

The following source materials were used in developing these toxicological profiles: when available, the EPA Integrated Risk Information System (IRIS) (EPA, 1994a); the Agency for Toxic Substances and Disease Registry Toxicological Profiles published by the Department of Health and Human Services (DHHS); the Handbook on the Toxicology of Metals (Friberg et al., 1986); and peer-reviewed scientific literature. By basing toxicity information on the standardized review documents cited above, the evaluation of risks at UMTRA sites should be consistent with evaluations at other sites.

The toxicity profiles presented here focus on available drinking water source material in humans, including animal data only when human data are not available. Animal information is represented on the toxicity range graphs by the use of widely spaced dotted lines. Uncertainty about the beginning or ending points of an exposure range producing specific toxic effects is denoted by closely spaced dots at the appropriate end of the range line.

\subsection{CONTAMINANT TOXICITY SUMMARIES}

The following summaries address the basic toxicokinetics and toxicity of the seven contaminants of potential concern for the Dilworth aquifer ground water at the Falls City uranium processing site.

The contaminants of potential concern for the Dilworth aquifer are cadmium, cobalt, fluoride, iron, nickel, sulfate, uranium and its longer-lived radioactive decay products (radium-226, lead-210, polonium-210, and thorium-230). Although these contaminants have a wide range of toxic effects depending on the exposure level, the following discussions focus on toxic effects observed in the exposure range most relevant to contamination at the Falls City site.

\subsubsection{Cadmium}

\section{Absorption}

In humans, approximately 5 percent of ingested cadmium in water is absorbed; however, this figure can increase substantially following exposure to other metals (such as calcium or iron) or with increased protein intake (Friberg et al., 1986). The amount of cadmium absorbed from food sources is about half the amount absorbed from water. Absorption also substantially increases in individuals with low iron stores (Flanagan et al., 1978). Once absorbed, cadmium is bound to protein, primarily metallothionein. The ability of many metals to increase the concentration of metallothionein is likely the basis for 
interactions in absorption, tissue concentrations, and toxicity of combined exposures to metals.

\section{Tissue accumulation and clearance}

Humans with low-level exposure to cadmium show 50 percent of the body burden in the kidneys, 15 percent in the liver, and 20 percent in muscle (Kjellström, 1979). The kidney concentration will increase with continued exposure only to about age 50 , but the concentration in muscle will increase throughout life. When high exposure results in kidney damage, kidney concentrations can be quite low, with liver concentrations up to 100 times higher than normal. Only 0.01 to 0.02 percent of the total body burden of cadmium is excreted daily, resulting in a continuously increasing body burden with prolonged exposure. The biological half-life of cadmium, or the time necessary to eliminate 50 percent of the cadmium in the body at a given time, is 10 to 30 years in humans (Nordberg et al., 1985).

\section{Environmental sources of cadmium}

The normal cadmium content of food and water in nonpolluted areas results in 0.01 to 0.06 milligrams $(\mathrm{mg})$ per day intake of cadmium $(0.0001$ to 0.0009 $\mathrm{mg} / \mathrm{kg}$-day) (Elinder, 1985). Cadmium occurs naturally with zinc and lead; therefore, it is often present as an impurity in products using these metals, such as solders and galvanized metals. These sources lead to contact with water supplies in water heaters, coolers, pipes, and taps.

\section{Toxicity of cadmium}

Acute exposure to high concentrations of cadmium (15 mg/L in water) results in acute gastrointestinal effects, including abdominal cramps, diarrhea, and vomiting $(0.07 \mathrm{mg} / \mathrm{kg})$. These gastrointestinal effects have not been reported for any chronic environmental exposure.

The primary toxic effect of long-term exposure to cadmium is disturbed reabsorption in the proximal tubules of the kidney. This effect is first evidenced by an increase of low molecular-weight proteins in the urine. This initial effect is observed following a daily intake of $0.0075 \mathrm{mg} / \mathrm{kg}$-day. Progressive disruption of kidney function will lead to an increase in amino acids, glucose, phosphate, and protein in the urine. Because of compromised kidney function, diabetics and the elderly can be more susceptible to cadmium toxicity (Buchet et al., 1990). Long-term exposures can also disturb calcium metabolism, leading to osteoporosis and osteomalacia. A combination of these two effects is referred to as Itai-itai disease and was seen in epidemic proportions in a cadmium- contaminated region of Japan in the 1950s (Friberg et al., 1986). Chronic dietary exposures of humans to cadmium produce no observable adverse effects at exposure levels from 0.001 to $0.002 \mathrm{mg} / \mathrm{kg}$-day (DHHS, 1993a). These health effects are summarized in Figure 5.1 as a function of dose. 


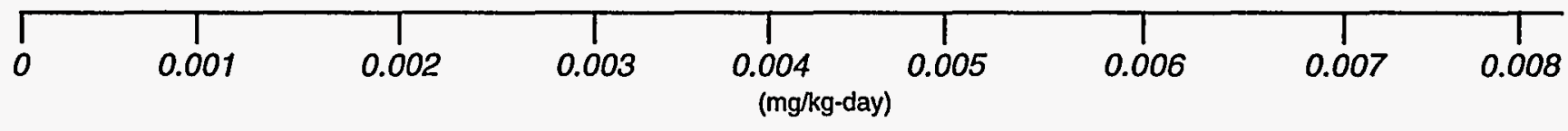

$$
\text { L }
$$

BACKGROUND INTAKE LEVELS

$\triangle$ ORAL REFERENCE DOSE - DRINKING WATER (0.0005 mg/kg-day)

............

NO OBSERVED EFFECTS FROM DRINKING WATER CONSUMPTION

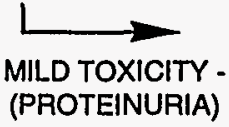

FIGURE 5.1

CADMIUM TOXICITY RANGES 
Cadmium has been classified as a probable human carcinogen by the EPA (EPA, 1994a) and International Agency for Research on Cancer (IARC) (IARC, 1987).

Although chronic inhalation of cadmium oxide has been related to increased lung and prostate cancers in workers, evidence linking cadmium to cancer in humans is inconclusive at this time because of the presence of other known carcinogens in the workplace and small statistical differences in tumor incidences (DHHS, 1993a). No data, however, link oral cadmium ingestion to cancer in humans or animals (DHHS, 1993a).

\subsubsection{Cobalt}

\section{Absorption}

Gastrointestinal absorption of soluble cobalt compounds is estimated to average about 25 percent, with wide individual variation; the gastrointestinal absorption in individuals reportedly varies from 5 to 45 percent (Friberg et al., 1986). Cobalt is an integral component of vitamin $B_{12}$. The total vitamin $B_{12}$ content of the body in a normal (i.e., nondeficient) adult human is about $5 \mathrm{mg}$, which is equivalent to about $0.2 \mathrm{mg}$ of cobalt (Friberg et al., 1986).

\section{Tissue accumulation and clearance}

In humans exposed to cobalt, the liver absorbs the highest concentration, followed by the kidneys. Excretion occurs mainly through the urinary tract. Apparently, most cobalt is eliminated rapidly (within days) for all exposure routes (inhalation, injection or ingestion). However, a small proportion is eliminated slowly, with a biological half-life on the order of years (Friberg et al., 1986).

Data are inadequate on the cobalt levels in tissues and fluids of normal populations (persons not occupationally exposed, i.e., background population) in the United States (DHHS, 1992a).

\section{Environmental sources of cobalt}

Cobalt occurs naturally in the earth's crust, and as a result, in soil. Cobalt compounds occur naturally in seawater and in some surface, spring, and ground water. Cobalt also is released into water from industrial and commercial sources. Cobalt is a by-product or coproduct of refining other mined metals (e.g., copper and nickel) (DHHS, 1992a).

\section{Toxicity of cobalt}

Cobalt is an essential nutrient as an integral component of vitamin $B_{12}$. No other function for cobalt in human nutrition has been established. Adding cobalt to beer has caused endemic outbreaks of cardiomyopathy (damage to the heart muscle) among heavy beer drinkers, with a 50-percent mortality rate. Similar effects on the heart, including myocardial degeneration and electrocardiographic 
changes, have been seen in laboratory animals after repeated parenteral or oral exposure to cobalt (Friberg et al., 1986).

The average daily intake of cobalt from food is 5 to 45 micrograms $(\mu \mathrm{g})$ (about 0.00007 to $0.0006 \mathrm{mg} / \mathrm{kg}$-day). The recommended daily intake of $\mathrm{B}_{12}$ for an adult is $3 \mu \mathrm{g}$, corresponding to $0.012 \mu \mathrm{g}$ of cobalt (Friberg et al., 1986)

Cobalt is used in the medical treatment of anemias and has an erythropoietic effect (i.e., it stimulates the production of red blood cells). Duckham and Lee (1976) gave 12 anemic patients daily oral doses of cobalt chloride in amounts corresponding to 6.2 and $12.4 \mathrm{mg}$ cobalt per day for a period of 12 to 30 weeks (approximately 0.09 to $0.13 \mathrm{mg} / \mathrm{kg}$-day). This treatment gave rise to an average 46-percent increase in the hemoglobin concentration. After cessation of cobalt treatment, the hemoglobin levels decreased. In addition to cardiomyopathy, polycythemia (increased number of red blood cells) was reported in heavy drinkers of cobalt-contaminated beer. It may be assumed that a really heavy beer drinker consuming up to $10 \mathrm{~L}$ per day of beer acquires an additional cobalt intake of approximately $10 \mathrm{mg}$ per day (approximately 0.04 to $0.14 \mathrm{mg} / \mathrm{kg}$-day). Although this range is high compared with nutritional standards, it is comparable to the doses given in the treatment of anemias (Friberg et al., 1986).

High levels of chronic oral exposure to cobalt may result in the production of goiter. Epidemiologic studies suggest that the incidence of goiter is higher in regions containing increased levels of cobalt in the water and soil. The goitrogenic effect has been elicited by oral administration of 3 to $4 \mathrm{mg} / \mathrm{kg}$ to children in the course of sickle cell anemia therapy (Casarett and Doull, 1991). The health effects from exposure to cobalt as a function of dose are summarized in Figure 5.2.

\subsubsection{Fluoride}

\section{Absorption}

Fluorides in water are absorbed primarily from the gastrointestinal tract. The degree of absorption depends on the solubility of a particular fluoride compound.

There are differences in fluoride absorption from food and drinking water. The absorption of fluoride from water is estimated to be 100 percent, while proteinbounding in food sources reduces dietary fluoride absorption. In young adults, the absorption of fluoride from milk or baby formula is determined to be only 72 and 65 percent, respectively, of that from water (National Research Council, 1989). Poorer absorption, from 37 to 54 percent, has been reported for the fluorine in bone meal.

\section{Tissue accumulation and clearance}

Fluoride has been detected in all organs and tissues. Following gastrointestinal absorption, fluoride is distributed primarily to bones and is deposited in the skeleton and tooth enamel with lesser deposition in the thyroid, aorta, and 


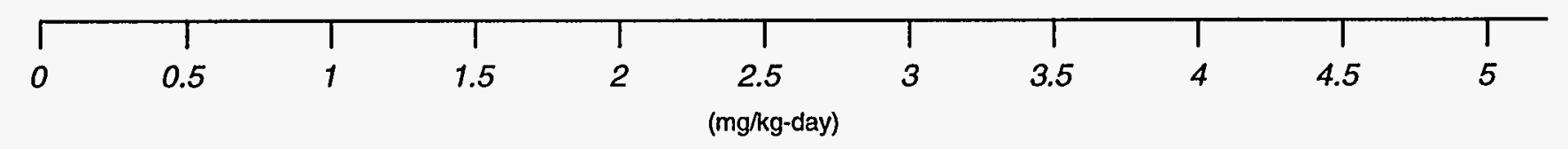

$\triangle$ NUTRITIONAL REQUIREMENT (0.0002 $\mu \mathrm{g} / \mathrm{kg}$-day)

A BACKGROUND INTAKE FROM DRINKING WATER (0.003 mg/kg-day)

U DIETARY INTAKE $(0.00007-0.0006 \mathrm{mg} / \mathrm{kg}$-day $)$

CARDIOMYOPATHY IN ADULT HUMANS

..

GOITROGENIC EFFECT IN CHILDREN

FIGURE 5.2

COBALT TOXICITY RANGES 
kidney (Gilman et al., 1990; National Research Council, 1989). The degree of skeletal storage is related to intake and age. Storage in bone is thought to be function of the turnover rate of skeletal components, with growing bone showing a greater fluoride deposition than in mature organisms. Prolonged periods of time are required for mobilization of fluoride from bone. The half-time for turnover in the young adult skeleton is about 8 to 10 years (Maheshwari et al., 1981).

The major route of fluoride excretion is the kidney; however, fluoride is also excreted in small amounts by the sweat glands, the lactating breast, and the gastrointestinal tract. Under conditions of excessive sweating the fraction of total fluoride excretion contributed by sweating can reach nearly one-half (Gilman et al., 1990). About 70 percent of the ingested fluoride is excreted in urine, and about 5 percent of that retained and absorbed is excreted in the feces (Maheshwari et al., 1981). About 90 percent of the fluoride filtered by the glomerulus is reabsorbed by the renal tubules (Gilman et al., 1990).

\section{Environmental sources of fluoride}

Drinking water and food are the primary sources of fluoride intake by humans. Drinking water, whether fluoridated or not, can contribute significantly to the total daily fluoride intake. In fluoridated areas, the contribution ranges from about 26 to 54 percent of the total intake (National Research Council, 1980). In unfluoridated areas, it ranges from about 14 to 48 percent.

Most public water supplies contain fluoride, and the majority of them contain less than $1 \mathrm{mg} / \mathrm{L}$ of fluoride $10.04 \mathrm{mg} / \mathrm{kg}$-day for a $25 \mathrm{~kg}$ child ingesting $1 \mathrm{~L}$ of water per day or $0.03 \mathrm{mg} / \mathrm{kg}$-day for a $70-\mathrm{kg}$ adult ingesting $2 \mathrm{~L}$ of water per day) (National Research Council, 1980). River water contains fluoride concentrations up to $6.5 \mathrm{mg} / \mathrm{L}$; lakes contain up to $1627 \mathrm{mg} / \mathrm{L}$; and sea water has an average concentration of $1.2 \mathrm{mg} / \mathrm{L}$.

The richest dietary sources of fluoride are tea and marine fish consumed with their bones (National Research Council, 1989). In the United Kingdom, tea accounted for 72 percent $(1.3 \mathrm{mg})$ of the total adult daily intake of $1.8 \mathrm{mg}$ (National Research Council, 1989). The fluoride content of cow's milk is approximately $0.02 \mathrm{mg} / \mathrm{L}$. Mean reported values for human milk range from 0.005 to $0.025 \mathrm{mg} / \mathrm{L}$, depending on maternal intake (mothers were drinking water containing 0.2 and $1.7 \mathrm{mg} / \mathrm{L}$, respectively). Dietary fluoride intake up to $3.44 \mathrm{mg}$ per day $(0.05 \mathrm{mg} / \mathrm{kg}$-day for a $70-\mathrm{kg}$ adult $)$ has been reported in some areas of the U.S. (National Research Council, 1980). Average fluoride dietary intake of $0.01 \mathrm{mg} / \mathrm{kg}$-day has been reported for both a $20-\mathrm{kg}$ child and a $70-\mathrm{kg}$ adult (EPA, 1994a).

Food processing has a substantial influence on the fluoride content of foods. The fluoride content of various foods can increase severalfold by cooking them in fluoridated water. Cooking in utensils treated with $\operatorname{Teflon}^{\oplus}$, a 
fluoride-containing polymer, can increase the fluoride content, whereas cooking in an aluminum container can reduce fluoride (National Research Council, 1989).

The estimated safe and adequate daily dietary intake (ESADDI) of fluoride for adults is 1.5 to $4.0 \mathrm{mg}$ per day (equivalent to 0.02 to $0.06 \mathrm{mg} / \mathrm{kg}$-day for a 70-kg man) (National Research Council, 1989). This accounts for widely varying fluoride concentrations of diets consumed in the U.S. and includes both food sources and drinking water. For younger age groups, the estimated maximum level of this intake is $2.5 \mathrm{mg}$ per day (equivalent to $0.1 \mathrm{mg} / \mathrm{kg}$-day for a 25-kg child). Ranges of 0.1 to $1 \mathrm{mg}$ per day during the first year of life (equivalent to 0.03 to $0.3 \mathrm{mg} / \mathrm{kg}$-day for a $4-\mathrm{kg}$ infant), and 0.5 to $1.5 \mathrm{mg}$ per day during the subsequent 2 years, are suggested as adequate and safe (National Research Council, 1989).

In view of fluoride's beneficial effects on dental health and its suggested safety at ESADDI levels, the Food and Nutrition Board recommends fluoridation of public water supplies if natural fluoride levels are substantially below $0.7 \mathrm{mg} / \mathrm{L}$ (National Research Council, 1989).

\section{Toxicity of fluoride}

Although fluoride can have beneficial effects on teeth and bone at low doses, at higher doses fluoride can be toxic. Children are particularly sensitive to dental fluorosis, the critical toxic effect of fluoride (EPA, 1994a). It has been established that fluoridation of water to a concentration of $1 \mathrm{mg} / \mathrm{L} 10.04 \mathrm{mg} / \mathrm{kg}$ day for a $25-\mathrm{kg}$ child assuming ingestion of $1 \mathrm{~L}$ of water) is a safe and practical public health measure that results in a substantial reduction in the incidence of caries in permanent teeth (Gilman et al., 1990). Fluoride is also used in clinical practice for the treatment of osteoporosis in larger doses than those used to prevent dental caries (Maheshwari et al., 1981). However, the optimal level of fluoride intake for osteoporosis therapy has not been determined.

Fluoride is an inhibitor of several enzyme systems and diminishes tissue respiration and anaerobic glycolysis. It also binds $\mathrm{Ca}(+2)$, and inhibits the glycolytic utilization of glucose by erythrocytes (Gilman et al., 1990).

Acute fluoride poisoning usually results from accidental ingestion of insecticides or rodenticides containing fluoride salts (Gilman et al., 1990). The lethal dose of fluoride for a $70-\mathrm{kg}$ adult is approximately $32 \mathrm{mg} / \mathrm{kg}$.

In man, the major manifestations of chronic ingestion of excessive amounts of fluoride are dental fluorosis (mottled enamel) and osteosclerosis (crippling skeletal fluorosis) (Gilman et al., 1990; National Research Council, 1989; Casarett and Doull, 1991). Long-term exposure to excess fluoride causes increased osteoblastic activity (a process of bone development).

In very mild tooth mottling, the gross changes consist of small, opaque, paperwhite areas scattered irregularly over the tooth surface. In severe cases, 
discrete or confluent, deep brown- to black-stained pits give the tooth a corroded appearance. Mottled enamel or dental fluorosis is the result of a partial failure of the enamel-forming cells properly to elaborate and lay down enamel. It is a nonspecific response to several stimuli, one of which is the ingestion of excessive amounts of fluoride.

Because mottled enamel is a developmental disease, the ingestion of fluoride following the eruption of the tooth has no effect (Gilman et al., 1990). Mottling is one of the first visible signs of an excessive intake of fluoride during childhood. Continuous use of water containing about 0.7 to $1.3 \mathrm{mg} / \mathrm{L}$ of fluoride (equivalent to 0.03 to $0.05 \mathrm{mg} / \mathrm{kg}$-day for a $25-\mathrm{kg}$ child, assuming ingestion of $1 \mathrm{~L}$ of water per day), depending on ambient temperature and diet, produces dental mottling and changes in tooth structure in 10 percent of children (National Research Council, 1980; Gilman et al., 1990). These effects were evaluated as the very mildest form of mottled enamel. At fluoride levels of 4 to $6 \mathrm{mg} / \mathrm{L}(0.16$ to $0.24 \mathrm{mg} / \mathrm{kg}$-day for a $25-\mathrm{kg}$ child, assuming ingestion of $1 \mathrm{~L}$ of water) the incidence reaches 100 percent, with marked increase in severity.

In osteosclerosis, as opposed to osteoporosis, the bone density and calcification increases. Fluoride intoxication is thought to represent the replacement of hydroxyapatite by the denser fluorapatite. However, the mechanism of its development is unknown. The degree of skeletal involvement varies from changes that are barely detectable radiologically to marked thickening of the cortex of long bones, numerous exostoses scattered throughout the skeleton, and calcification of ligaments, tendons, and muscle attachments to bone. In its severest form, osteosclerosis is a disabling disease and is designated as crippling fluorosis. It has been estimated that the development of crippling skeletal fluorosis in humans requires daily ingestion of 20 to $80 \mathrm{mg}$ fluoride (0.29 to $1.1 \mathrm{mg} / \mathrm{kg}$-day for a $70-\mathrm{kg}$ adult) over a 10 - to 20-year period (National Research Council, 1980; 1989; EPA, 1994a). Although the no observed effect level for crippling skeletal fluorosis in humans is unknown, a safe total fluoride exposure level (from food and drinking water) for adults is suggested to be 0.12 $\mathrm{mg} / \mathrm{kg}$-day. This exposure level would correspond to the consumption of $2 \mathrm{~L}$ of water per day containing $4 \mathrm{mg} / \mathrm{L}$ of fluoride by a $70-\mathrm{kg}$ adult and ingestion of $0.01 \mathrm{mg}$ per day of fluoride in the diet.

The EPA oral reference dose (RfD) of $0.06 \mathrm{mg} / \mathrm{kg}$-day was developed based on the no observed adverse effect level (NOAEL) of $1 \mathrm{mg}$ fluoride per liter of drinking water, determined in children from 12 to 14 years old, and the assumption that a $20-\mathrm{kg}$ child consumes $0.01 \mathrm{mg}$ fluoride/ $\mathrm{kg}$-day in the diet (EPA, 1994a).

The health effects of fluoride are summarized in Figure 5.3 as a function of dose. 


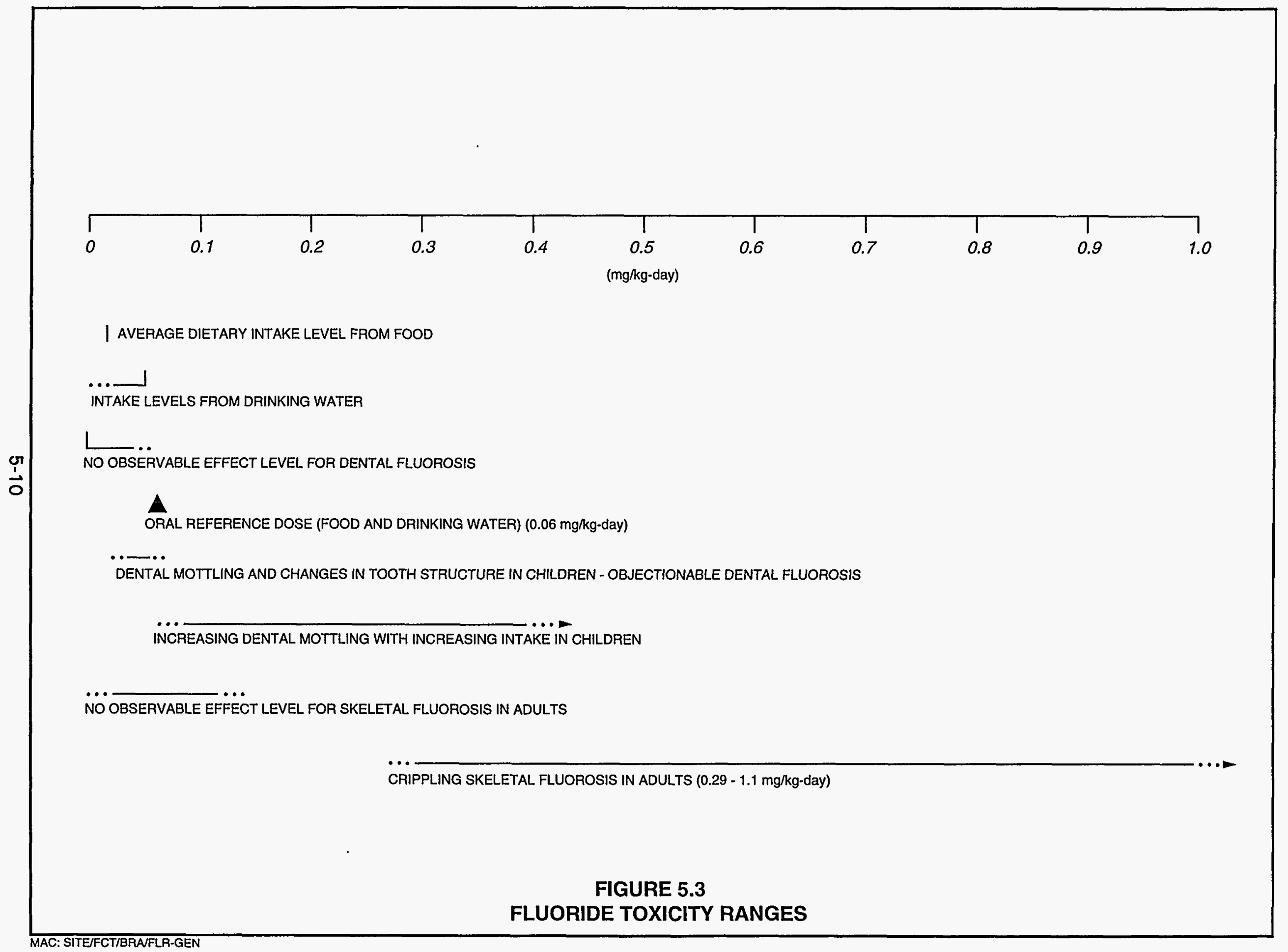




\subsubsection{Iron}

\section{Absorption}

The percentage of dietary iron that is absorbed ranges from 2 percent in individuals with diseases of the gastrointestinal tract to 35 percent in rapidly growing, healthy children (Goyer, 1991; Whitney et al., 1990). Normally, 10 to 15 percent of dietary iron is absorbed, but this percentage varies to compensate for the level of iron in the body (Elinder, 1986). For example, patients with irondeficiency anemia can absorb as high as 60 percent of an oral dose of iron (Josephs, 1958).

Iron absorption also is influenced by factors such as the source and chemical form of the ingested iron, other substances in the diet, and the condition of the gastrointestinal tract (Elinder, 1986). Very little is known about the absorption of iron from water and about the chemical species of iron in drinking water from the tap. Although the amount of ferric ion $\left(\mathrm{Fe}^{3+}\right)$, ferrous ion $\left(\mathrm{Fe}^{2+}\right)$ and organic complexes of iron in water that are absorbed by humans is unknown, it is clear that reducing agents such as ascorbic acid increase the absorption of iron in food (National Research Council, 1980). Ferrous ion appears to have better availability than does ferric ion. Iron from animal sources is absorbed by humans more effectively than iron from vegetables and grains. Soluble forms of iron such as iron sulfate are taken up more readily than insoluble forms such as iron oxide. In the Dilworth ground water at the Falls City site, iron is present predominantly in the form of ferrous ion and also as ferrous sulfate (Table 3.5). Therefore, iron forms present in the Dilworth ground water may be absorbed readily.

The presence of other metals also affects iron absorption. Absorption is decreased in the presence of high levels of phosphate, cobalt, copper, and zinc (Elinder, 1986). Excess manganese can significantly decrease iron absorption by impairing hemoglobin regeneration in the blood (National Research Council, 1980).

\section{Tissue accumulation and clearance}

Iron absorption from the gastrointestinal tract occurs in two steps: first, ferrous ions from the intestinal lumen are absorbed into the mucosal cells; second, they are transferred from the mucosal cells to plasma, where they are bound to transferrin for transfer to storage sites. As ferrous ion is released into plasma, it is oxidized by oxygen in the presence of ferroxidase I (Goyer, 1991).

Normally, the adult human body contains about 3 to 5 grams of iron. Two-thirds of this amount is found in the blood, bound to hemoglobin. Less than 10 percent of the body iron is found in myoglobin and iron-requiring enzymes. About 20 to 30 percent of the remaining iron in the body pool is bound to iron-storage proteins in the liver, bone marrow, and spleen (Elinder, 1986). 
Under normal conditions, the total elimination of iron from the body is limited to 0.6 to $1.0 \mathrm{mg}$ per day, or roughly 0.01 percent of the body stores. Of the iron absorbed from the gut, about 0.2 to $0.5 \mathrm{mg}$ of elemental iron per day is eliminated through the feces and about 0.1 to $0.3 \mathrm{mg}$ per day is eliminated in urine. The remainder is eliminated through normal dermal losses in sweat, hair, and nails. Based on these rates of elimination, the biological half-life of iron in the body is estimated at 10 to 20 years (Elinder, 1986).

\section{Environmental sources of iron}

The iron concentrations of liver, kidney, beef, ham, egg yolk, and soybeans are in the order of 30 to $150 \mathrm{mg} / \mathrm{kg}$ fresh weight. Grains and fruits are low in iron, usually ranging from 1 to $20 \mathrm{mg} / \mathrm{kg}$. In both human and cow's milk, iron concentration is about $0.5 \mathrm{mg} / \mathrm{L}$ (Elinder, 1986).

The average daily intake of iron ranges from 9 to $35 \mathrm{mg}$ per day 10.1 to $0.5 \mathrm{mg} / \mathrm{kg}$-day) (Elinder, 1986). Approximately 35 percent of dietary iron comes from meat, fish, and eggs, while 50 percent is supplied by cereals, root vegetables, and other foods of plant origin (National Research Council, 1980).

Iron concentrations in water vary greatly. In the United States, the iron concentrations of freshwater and public water supplies range from 0.01 to $1.0 \mathrm{mg} / \mathrm{L}$ (Elinder, 1986). Assuming a $2 \mathrm{~L}$ per day consumption of water by a $70-\mathrm{kg}$ (body weight) adult, this range would result in an intake of 0.0003 to $0.03 \mathrm{mg} / \mathrm{kg}$-day of iron from drinking water.

The RDA for iron is $10 \mathrm{mg}$ (approximately $0.14 \mathrm{mg} / \mathrm{kg}$-day) for adult males and $18 \mathrm{mg}$ (approximately $0.25 \mathrm{mg} / \mathrm{kg}$-day) for females of reproductive age (National Research Council, 1980).

\section{Toxicity of iron}

Iron intoxication is most frequent in children aged of 1 to 3 years due to ingestion of adult iron supplements in the form of ferrous sulfate tablets with candy-like coatings. Severe poisoning in children may occur following ingestion of more than 0.5 grams (approximately $22 \mathrm{mg} / \mathrm{kg}$ ) of iron, about $2.5 \mathrm{grams}$ (approximately $110 \mathrm{mg} / \mathrm{kg}$ ) as ferrous sulfate. This acute iron poisoning has occurred in children who ingested as few as 6 iron tablets (Whitney et al., 1990). Excessively high iron intake damages the lining of the gastrointestinal tract, producing vomiting as the first symptom. Bleeding of the damaged gastrointestinal tissue frequently results in blood in the vomit and black stools (Goyer, 1991). Shock and metabolic acidosis can develop. If the patient survives the initial crisis, liver damage with hepatitis and coagulation defects often occur within a few days. Renal failure and cirrhosis of the liver may occur as delayed effects (Elinder, 1986).

Long-term intake of iron in a form that is readily absorbed and in doses exceeding 50 to $100 \mathrm{mg}$ of iron per day 10.7 to $1.4 \mathrm{mg} / \mathrm{kg}$-day for a $70-\mathrm{kg}$ adult 
male) (Elinder, 1986) results in an increased body burden of iron because iron is removed from the body at a much slower rate than it is absorbed. As the body burden of iron increases to between 20 and 40 grams (roughly 10 times the normal level), production of the iron-binding protein hemosiderin increases and results in a condition known as hemochromatosis. This condition starts with increased pigmentation of the skin and higher concentrations of iron in the liver, pancreas, endocrine organs, and heart. This increased tissue iron can produce cirrhosis of the liver, disturbances in endocrine and cardiac function, and diabetes mellitus (Goyer, 1991).

Chronic iron toxicity in adults can be caused by genetic factors, excess dietary iron, excessive ingestion of iron-containing tonics or medicines, or multiple blood transfusions. The pathologic consequences of iron overload are similar regardless of basic cause (Goyer, 1991).

The health effects from exposure to iron as a function of dose are summarized in Figure 5.4.

\subsubsection{Nickel}

\section{Absorption}

Studies in humans report that 27 percent of inorganic nickel (administered as nickel sulfate) was absorbed when it was administered in drinking water, whereas only 0.7 percent was absorbed when it was given in food. In a separate study, the bioavailability of nickel, as measured by serum nickel levels, increased by $80 \mu \mathrm{g} / \mathrm{L}$ after 3 hours in fasted individuals who ingested nickel sulfate in drinking water, but was not elevated in individuals who ingested nickel in food (DHHS, 1993b). Other human studies show that generally less than 10 percent of ingested nickel is absorbed by the gastrointestinal tract. This finding is consistent with studies reporting from 1 to 10 percent oral absorption in several animal species (Friberg et al., 1986). Absorbed nickel is transported in the plasma bound to serum albumin and various organic ligands, amino acids, or polypeptides (Casarett and Doull, 1991). Nickel has been found to affect gastrointestinal absorption of iron, but only when iron was administered as ferric sulfate (DHHS, 1993b).

\section{Tissue accumulation and clearance}

In humans, serum nickel levels reportedly peak 2.5 to 3 hours after ingestion of nickel sulfate. In individuals who accidentally drank water contaminated with nickel sulfate and nickel chloride, the mean serum nickel half-life was 60 hours. No human data were located regarding nickel levels in specific tissues or organs following ingestion of nickel compounds.

In animals, various nickel compounds administered orally distributed primarily to the kidneys, with significant nickel levels also found in the liver, heart, lung, fat, peripheral nervous tissues, and brain. Increased levels of nickel also were found 


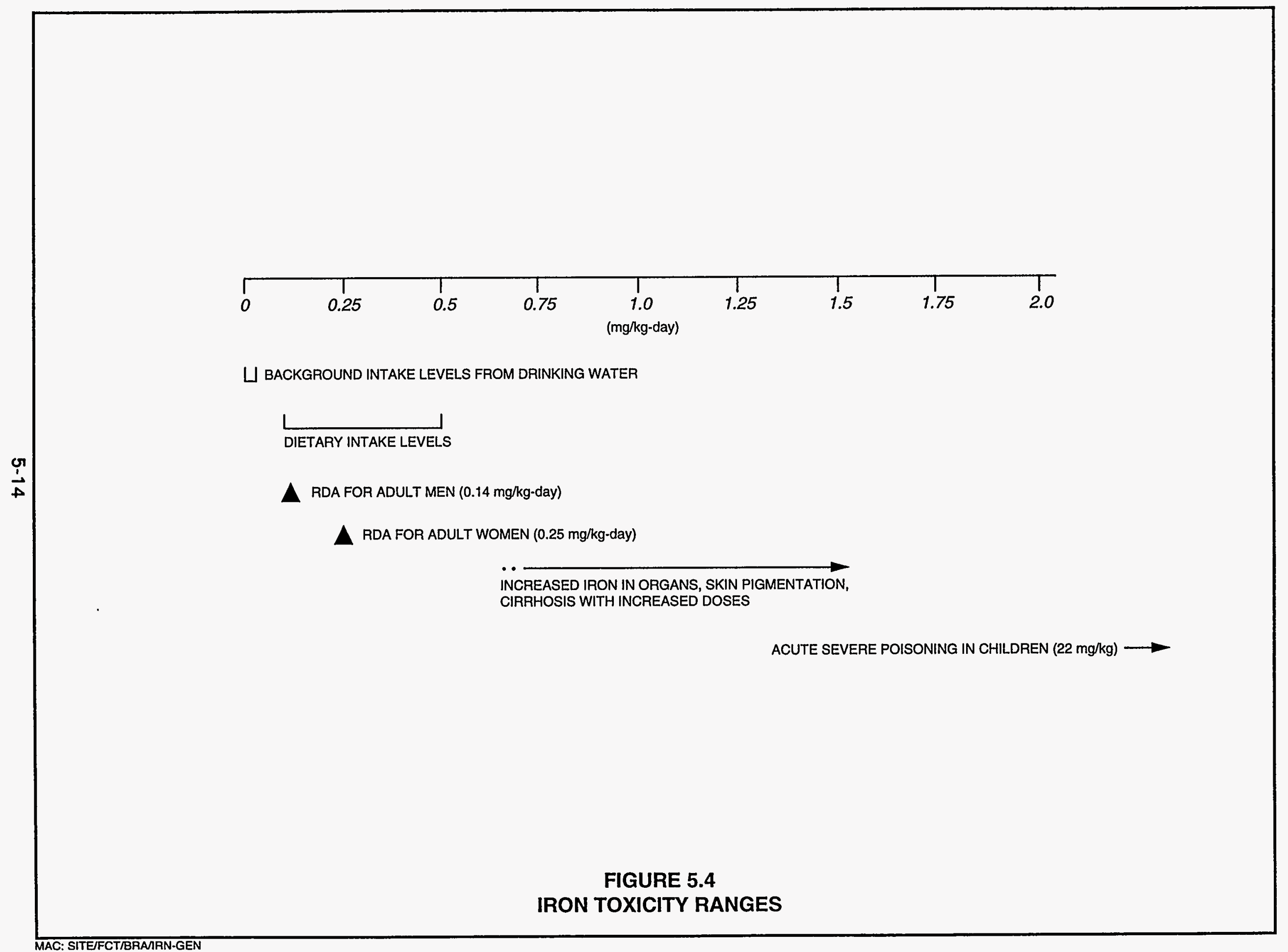


in the fetuses of animals exposed orally to nickel compounds, suggesting that nickel crosses the placental barrier (DHHS, 1993b).

In humans, the majority of ingested nickel is excreted in the feces, due to limited absorption. Nickel absorbed in the gastrointestinal tract is excreted in the urine. Excretion of a given dose of nickel is nearly complete in 4 or 5 days (Casarett and Doull, 1991), with approximately 26 percent of the dose excreted in the urine and the remainder eliminated in the feces (DHHS, 1993b).

\section{Environmental sources of nickel}

Exposure to nickel can occur through inhalation of ambient air and tobacco smoke, and ingestion of water and food. Most intake occurs through the diet (DHHS, 1993b). In grains, fresh weight nickel concentrations reportedly range from 0 to 6.45 micrograms per gram $(\mu \mathrm{g} / \mathrm{g})$. In vegetables and fruits, levels range from 0 to $2.59 \mu \mathrm{g} / \mathrm{g}$ and in seafood from 0.3 to $107 \mu \mathrm{g} / \mathrm{g}$. Average daily dietary intake is approximately $165 \mu \mathrm{g}$ (Friberg et al., 1986). The drinking water daily intake averages $2 \mu \mathrm{g}$ (DHHS, 1993b).

Nickel is not commonly present at harmful levels in ground water. In a survey of United States ground water, 97 percent of all samples (total of 2053 samples) contained less than 20 micrograms per liter $(\mu \mathrm{g} / \mathrm{L})$ of nickel and 80 percent had less than $10 \mu \mathrm{g} / \mathrm{L}$, although in areas near nickel mining operations, levels as high as $200 \mu \mathrm{g} / \mathrm{L}$ have been reported (Friberg et al., 1986).

\section{Toxicity of nickel}

Acute exposure to high levels of nickel in drinking water (1-day duration) reportedly produced symptoms of gastrointestinal distress including nausea, abdominal cramps, diarrhea, and vomiting. The estimated exposure dose of 7.1 to $35.7 \mathrm{mg} / \mathrm{kg}$ also produced transient hematological effects, muscle pain, transient increases in urine albumin, and neurological effects (giddiness and weariness).

The effects of chronic nickel ingestion in humans have not been well documented. In laboratory animals (dogs and rats), the primary effects of longterm dietary administration of nickel sulfate were decreases in body weight and changes in organ weights. Low hematocrit and polyuria were also reported for dogs (DHHS, 1993b). Rats appear to be the more sensitive of the two species. The lowest nickel dose of $35 \mathrm{mg} / \mathrm{kg}$-day, administered to rats in water by gavage, resulted in decreased body and internal organ weights as determined in a subchronic toxicity study (EPA, 1994a).

A susceptible population may exhibit a different or enhanced response to nickel than will most persons exposed to the same level of nickel in the environment. Chemical exposure history, genetic make-up, developmental state, health, and nutritional status affect the detoxification and excretory processes (mainly hepatic and renal). For these reasons, it is expected that the elderly (with 
declining organ function) and the youngest of the population (with immature and developing organs) are generally more vulnerable to toxic substances than are healthy adults.

Exposure to nickel may lead to sensitization. Available data indicate that oral exposure to relatively low levels of nickel may elicit allergic dermatitis in sensitized individuals (DHHS, 1993b). Epidemiologic studies indicate that blacks have a higher sensitivity than whites and that women of either racial group have higher reaction rates than do men (DHHS, 1993b). The incidence of allergic reactions may be higher in women because they wear more metal jewelry than men. The response threshold may be approximately $0.007 \mathrm{mg} / \mathrm{kg}$-day following oral challenge. Cross-sensitivity of nickel and other metals (e.g., cobalt) has also been reported (DHHS, 1993b).

For the rat, a no-observed-adverse-effect level (NOAEL) of 100 parts per million (ppm) of nickel in the diet (5 mg/kg-day) was reported. The EPA chronic RfD for human exposure to nickel was derived based on this NOAEL. Considering the uncertainties with interspecies extrapolation and protection of sensitive populations, an oral RfD of $0.02 \mathrm{mg} / \mathrm{kg}$-day has been developed for nickel (EPA, 1994a). This value represents a chronic daily ingestion dose which is not expected to produce adverse health effects in humans.

The potential health effects from exposure to nickel as a function of dose are summarized in Figure 5.5.

\subsubsection{Sulfate}

\section{Absorption}

Sulfate absorption from the gastrointestinal tract is similar in humans and other animals. Generally, greater than 90 percent absorption is reported for sulfate doses below $150 \mathrm{mg} / \mathrm{kg}$, decreasing to 50 to 75 percent as the dose increases into the grams-per-kilogram range.

\section{Tissue accumulation and retention}

Ingesting high levels of sulfate results in transient increases in both blood and urine concentrations. Approximately 50 percent of a $75-\mathrm{mg} / \mathrm{kg}$ dose is excreted over 72 hours. The urinary excretion mechanism is transport-limited and can therefore become saturated at high doses of sulfate. Excess sulfate is also excreted in feces in its inorganic form. To date, no data indicate sulfate accumulates, even with chronic ingestion of above-normal levels. However, extremely high chronic doses have not been examined in humans.

Sulfate is used in the biosynthesis of collagen, cartilage, and dentin and in the formation of sulfate esters of both endogenous compounds (such as lipids and steroids) and exogenous compounds (such as phenols). Sulfation is important in detoxication pathways because it increases the solubility of these compounds, 


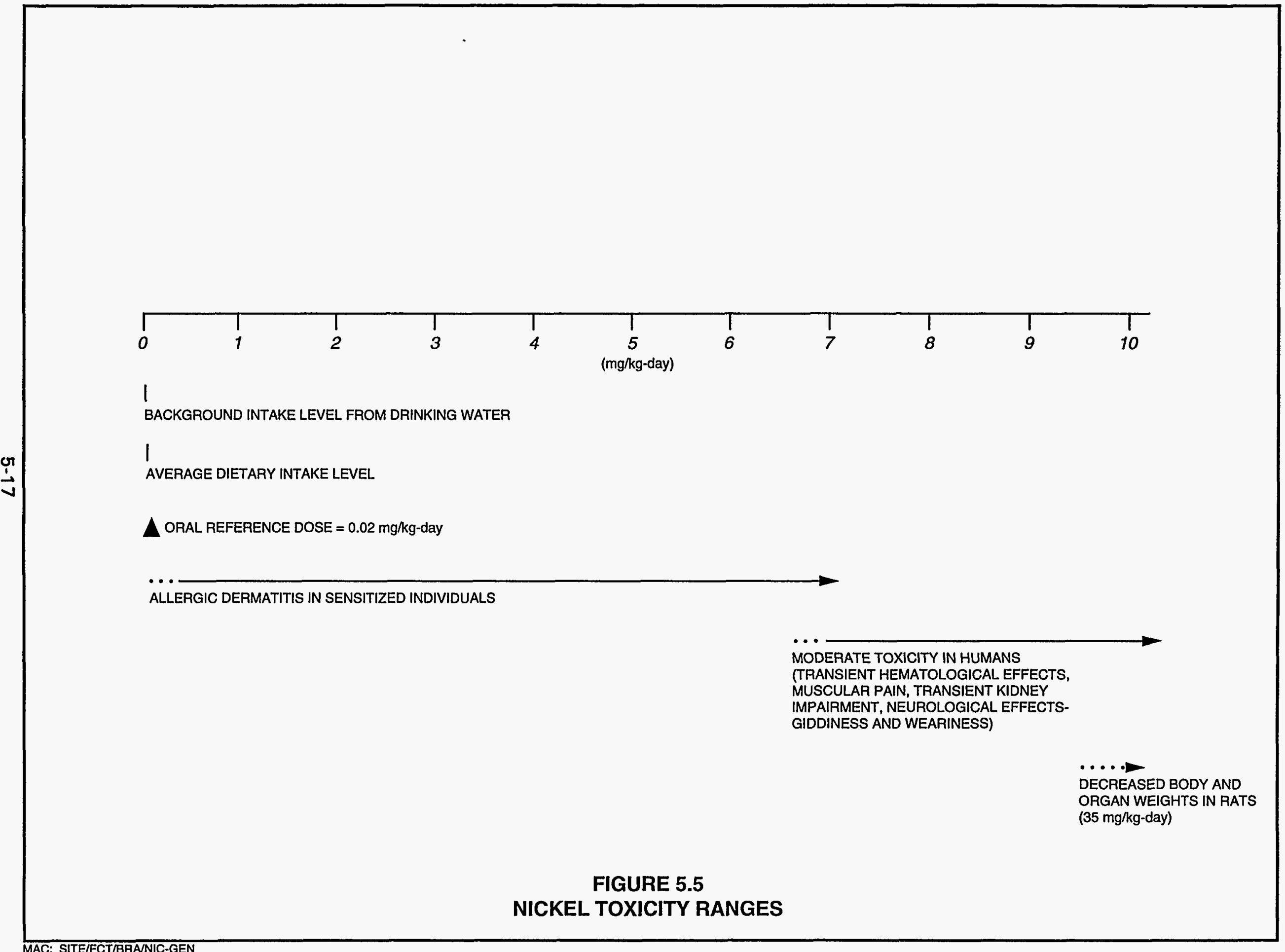


which enhances their excretion in the urine. Exposure to high concentrations of compounds that are conjugated with sulfate and excreted can produce a transient decrease in plasma sulfate concentrations.

\section{Environmental sources of sulfate}

Drinking water sulfate concentrations in the western United States in 1978 ranged from 0 to $820 \mathrm{mg} / \mathrm{L}$, with a mean concentration of $99 \mathrm{mg} / \mathrm{L}$. The EPA estimates a normal sulfate intake range of 0.00023 to $0.0064 \mathrm{mg} / \mathrm{kg}$-day from air and up to $2.9 \mathrm{mg} / \mathrm{kg}$-day from drinking water in the western United States. No estimates are available on sulfate intake from food.

\section{Toxicity of sulfate}

The acute and chronic effects of sulfate toxicity differ more in severity than in symptoms or mechanisms. Therefore, this discussion will combine acute and chronic toxicity. As discussed above, no data indicate sulfate bioaccumulation with chronic exposure. Sulfate salts of magnesium and sodium are used medicinally as cathartics. High concentrations of unabsorbed sulfate salts in the gut can pull large amounts of water into the gut, greatly increasing the normal volume of feces. This is the basis of the toxic effects as well.

Toxicity in humans is primarily manifested in diarrhea; the severity of the diarrhea is dose-dependent. Chronic sulfate ingestion can result in persistent diarrhea, leading to ionic imbalance and dehydration similar to that seen with extremely high acute doses. Serious gastroenteritis is reported in some infants and adults drinking water containing 400 to $1000 \mathrm{mg} / \mathrm{L}$ sulfate (EPA, 1992a). When drinking water is contaminated with sulfate, the taste of the water may make it unpalatable and reduce consumption. However, this is not necessarily the case. In regions (such as Saskatchewan) with high sulfate concentrations in the drinking water, residents adapt to the taste and find the water palatable (EPA, 1992a). A lower water intake could compound the dehydration effects of the diarrhea. Extreme dehydration can lead to death. As with nitrate toxicity, infants seem to be the most susceptible population for sulfate-induced diarrhea. Also, some data indicate diabetic and elderly populations with compromised kidney function may be more sensitive than healthy adults to the effects of sulfates (EPA, 1992a). These health effects are summarized in Figure 5.6 as a function of dose.

Data on sulfate toxicity are based primarily on epidemiologic studies of human adults and infants who report to hospitals with symptoms of sulfate exposure. In most cases, exposure doses have been back-calculated from sampling their drinking water. Therefore, these data do not represent well-controlled studies with readily defined dosage ranges. 


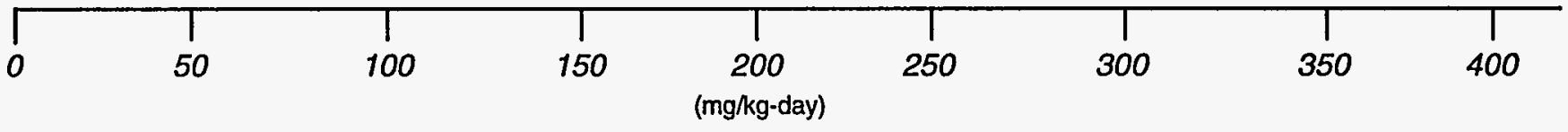

山

BACKGROUND INTAKE LEVELS

No ÖBSERVED EFFECTS

… -

MILD TOXICITY RANGING FROM LAXATIVE EFFECT (ADULTS) TO DIARRHEA IN INFANTS

S̈EVERE TOXICITY - PERSISTENT INFANT DIARRHEA LEADING TO DEHYDRATION $\cdots$

FIGURE 5.6

SULFATE TOXICITY RANGES 


\subsubsection{Uranium}

The uranium that occurs naturally at UMTRA Project sites consists of three radioactive isotopes: uranium-234, uranium-235, and uranium-238. More than 99 percent of natural uranium occurs in the form of uranium-238 (Cothern and Lappenbusch, 1983). Uranium-238 undergoes radioactive decay by emitting alpha particles to form uranium-234, thorium-230, radium-226, radon 222 , polonium-210, and other radioisotopes. The radioactive decay chain of uranium238 and uranium-234 is summarized in Figure 5.7. As all natural uranium isotopes are radioactive, the hazards of a high uranium intake are from both its chemical toxicity and potential radiological damage. This section focuses on the chemical toxicity of natural uranium. The carcinogenic potential associated with exposure to radioactive isotopes of natural uranium is discussed in Section 5.3.

\section{Absorption}

Absorption of uranium in the gastrointestinal tract depends on the solubility of the uranium compounds. The hexavalent uranium compounds, especially the uranyl salts, are water soluble, while tetravalent compounds generally are not (Weigel, 1983). Even with soluble compounds, only a small fraction is absorbed. Human gastrointestinal absorption rates of 0.76 to 7.8 percent have been determined (Wrenn et al., 1985).

\section{Tissue accumulation and clearance}

In humans exposed to background levels of uranium, the highest concentrations were found in the bones, muscles, lungs, liver, and kidneys (Fisenne et al., 1988). Uranium retention in bone consists of a short retention half-time of $\mathbf{2 0}$ days, followed by a long retention half-time of $\mathbf{5 0 0 0}$ days for the remainder (Tracy et al., 1992).

In body fluids, uranium tends to convert into water-soluble hexavalent uranium (Berlin and Rudell, 1986). Approximately 60 percent of the uranium in plasma complexes with low-molecular-weight anions (e.g., bicarbonates, citrates), while the remaining 40 percent binds to the plasma protein transferrin (Stevens et al., 1980). Following oral exposure in humans, more than 90 percent of uranium is excreted in the feces and is not absorbed in the gastrointestinal tract. Of the small percent that is absorbed (typically less than 5 percent), approximately 60 percent is excreted in the urine within 24 hours and 98 percent is excreted within 7 days, based on animal studies (Ballou et al., 1986; Leach et al., 1984; Sullivan et al., 1986). A small portion of the absorbed uranium is retained for a longer period.

\section{Environmental sources of uranium}

Uranium is a ubiquitous element, present in the earth's crust at approximately 4 parts per million. Uranium concentrations in ground water and surface water averaged $1 \mathrm{pCi} / \mathrm{L}$ and $3 \mathrm{pCi} / \mathrm{L}$, respectively (NCRP, 1984). The extent of 


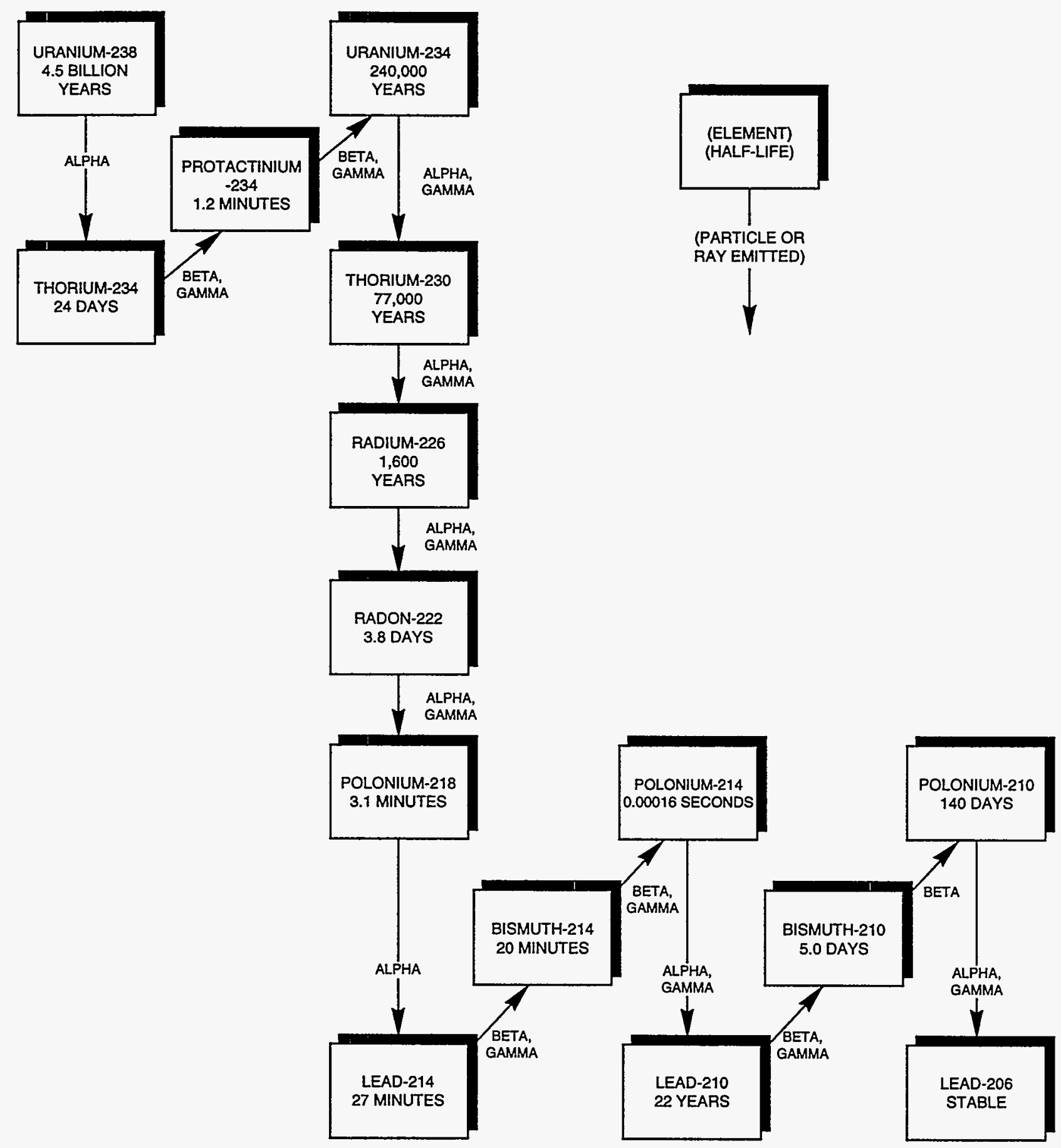

FIGURE 5.7

HALF-LIVES AND EMISSIONS FROM DECAY CHAIN OF URANIUM-238 
absorption from the soil into plant tissues depends on the plant species and the depth of its root system (Berlin and Rudell, 1986). Plant uranium concentrations averaged $0.075 \mu \mathrm{g} / \mathrm{kg}$ of fresh plant material (Tracy et al., 1983).

The main dietary source of natural uranium for the general population is food (e.g., potatoes, grain, meat, and fresh fish) which may contain uranium concentrations between 10 and $100 \mu \mathrm{g} / \mathrm{kg}$ (Prister, 1969). The total uranium dietary intake from the consumption of average foods is approximately $1 \mu \mathrm{g}$ per day; additionally, approximately 20 to 50 percent of that total can come from drinking water. Cereals and vegetables, particularly root crops, are likely to contribute most to daily uranium intake (Berlin and Rudell, 1986).

\section{Toxicity of uranium}

Exposure of the general public to natural uranium is unlikely to pose an immediate lethal threat to humans. No human deaths have been reported that are definitely attributable to uranium ingestion; therefore, no lethal dose has been determined for humans. Lethal doses of uranium $\left(L D_{50,23}\right)$ are reported to be as low as $14 \mathrm{mg} / \mathrm{kg}$-day following 23-day oral exposures, depending on the solubility of the uranium compound tested (higher solubility compounds have greater toxicityl, route of exposure, and animal species. High doses of uranium cause complete kidney and respiratory failure.

No chronic toxic effects are reported in humans following oral exposure to uranium. Data from populations occupationally exposed to high concentrations of uranium compounds through inhalation and information from studies on experimental animals indicate the critical organ for chronic uranium toxicity is the proximal tubule of the kidney (Friberg et al., 1986). In humans, chemical injury reveals itself by increased catalase excretion in urine and proteinuria. Dose-response data for the toxic effects of uranium on the human kidney are limited.

The lowest dose of uranyl nitrate that caused moderate renal damage was given to rabbits in diet at $2.8 \mathrm{mg} / \mathrm{kg}$-day (Maynard and Hodge, 1949). The health effects for uranium are summarized in Figure $\mathbf{5 . 8}$ as a function of dose.

\subsection{CONTAMINANT INTERACTIONS}

Some information is available on potential interactions between contaminants found at UMTRA sites. However, discussions of potential interactions can generally be presented only qualitatively. In addition to physiological variables between individuals that can affect toxicity, uncertainties in interactions also result from 1) differences in the relative exposure concentrations of the different contaminants compared to the concentrations tested experimentally; and 2) the presence of additional ground water constituents that may occur in sufficient quantities to modify predicted toxicities even though they themselves are not considered contaminants of concern for human health. Therefore, the interactions described below should be recognized as factors that can influence 


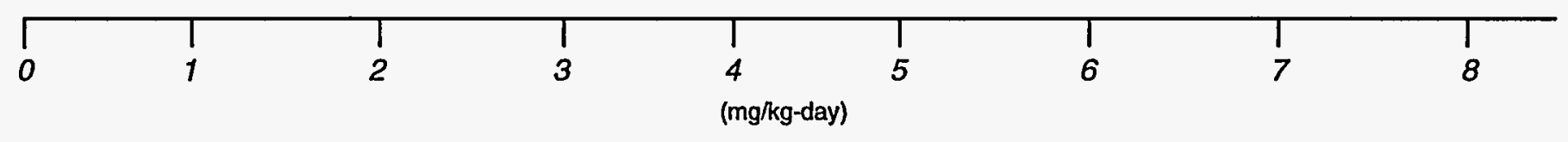

I

DIETARY INTAKE

$\triangle$ ORAL REFERENCE DOSE (0.003 mg/kg-day)

REVERSIBLE KIDNEY IMPAIRMENT AFTER ACUTE HUMAN EXPOSURE

(BASED ON DOSE RECONSTRUCTION, CASE STUDY)

- • • • • • • • • • • • • • • • • •

NO OBSERVED EFFECTS IN EITHER MICE OR RATS

(SUFFICIENT HUMAN DATA NOT AVAILABLE)

L...

MILD TOXICITY

(RABBITS, RENAL DAMAGE)

FIGURE 5.8

URANIUM TOXICITY RANGES 
the predicted toxicity, although the precise nature and magnitude of that influence cannot be determined.

A primary concern at the Falls City site is the potential for interactions between the metals observed in the Dilworth contaminated ground water. Interactions between several similar metals can alter the predicted absorption distribution in the body, metabolism, toxicity, or clearance of a metal of interest.

For example, absorption of cadmium from the intestine may significantly decrease in the presence of high dietary iron, leading to decreased toxicity of cadmium (Flanagan et al., 1978). In addition, cadmium and nickel can induce synthesis of the metal binding protein metallothionein (Casarett and Doull, 1991: DHHS, 1993a, 1993b). This protein seems to have a paradoxical effect on the systemic toxicity of cadmium. Metallothionein appears to bind cadmium, thus protecting certain organs (such as the testes) from cadmium toxicity. However, metallothionein also may enhance cadmium nephrotoxicity, possibly because the cadmium-metallothionein complex is taken up by the kidney more readily than is the free ion. Because both cadmium and nickel bind to metallothionein in the continued presence of both nickel and cadmium, there may be competition for metallothionein binding sites. Formation of metallothionein-nickel complex would enhance nickel excretion, decreasing its toxicity. However, cadmium may enhance the nephrotoxicity and hepatotoxicity of nickel (DHHS, 1993b). Cadmium-damaged renal cells may be more susceptible to nickel, or cells not damaged by cadmium may be damaged by nickel; however, the mechanism of this interaction could not be ascertained.

Under conditions of high iron levels, nickel may inhibit the passive diffusion of iron, decreasing its gastrointestinal absorption and therefore toxicity, but only when iron is present as ferric ion (DHHS, 1993b). In the Dilworth ground water, based on geochemical models, all detected iron exists in the form of ferrous ions (Table 3.5). Therefore, the nickel in the ground water at this site is not expected to affect iron absorption. However, iron absorption would be expected to decrease in the presence of high levels of cobalt (Elinder, 1986; National Research Council, 1980).

Nickel and cobalt sensitization are interrelated in individuals exposed to the two metals (DHHS, 1992a; 1993b). The combination of nickel and cobalt sensitivity and irritant eczema may result in a risk for developing an allergy to cobalt.

In animal studies, iron status affected the gastrointestinal absorption of uranium; however, the reported results were inconclusive (EPA, 1989c). No other information on uranium interactions with other metals has been found. However, the common target organ suggests interaction of uranium with cadmium and nickel in the production of kidney toxicity. 


\subsection{CONTAMINANT RISK FACTORS}

The EPA Office of Research and Development has calculated acceptable intake values, or RfDs, for long-term (chronic) exposure to noncarcinogens. These values are estimates of route-specific exposure levels that would not be expected to cause adverse effects when exposure occurs for a significant portion of a lifetime. The RfD derivations include safety factors to account for uncertainties associated with limitations of the toxicological data base, including extrapolating results from animal studies to humans and accounting for variability in response for sensitive individuals. RfD values are updated quarterly and are published in the Health Effects Assessment Summary Tables (HEAST) (EPA, 1994b). Following a more stringent review, they are published through the EPA's Integrated Risk Information System (IRIS) data base (EPA, 1994a). The most recent oral RfDs for the noncarcinogenic contaminants of potential concern are summarized in Table 5.1.

The EPA currently classifies all radionuclides as Group A, or known human carcinogens, based on their property of emitting ionizing radiation and on the evidence provided by epidemiological studies of radiation-induced cancer in humans. At sufficiently high doses, ionizing radiation acts as a complete carcinogen (both initiator and promoter), capable of increasing the probability of cancer development. However, the actual risk is difficult to estimate, particularly for the low dose and dose rates encountered in the environment. Most reliable data were obtained under conditions of high doses delivered acutely. It is not clear whether cancer risks at low doses are dose proportional (i.e., the linear dose-response hypothesis) or whether the risk is greatly reduced at low doses and rates (the threshold hypothesis). A conservative assumption is that no threshold dose exists below which there is an additional risk of cancer.

Risk factors published in HEAST and IRIS correlate the intake of carcinogens over a lifetime with the increased excess cancer risk from that exposure. The most recent cancer slope factors (SF) for the longer-lived progeny of the uranium-234/-238 radioactive decay series are given in Table 5.2. 


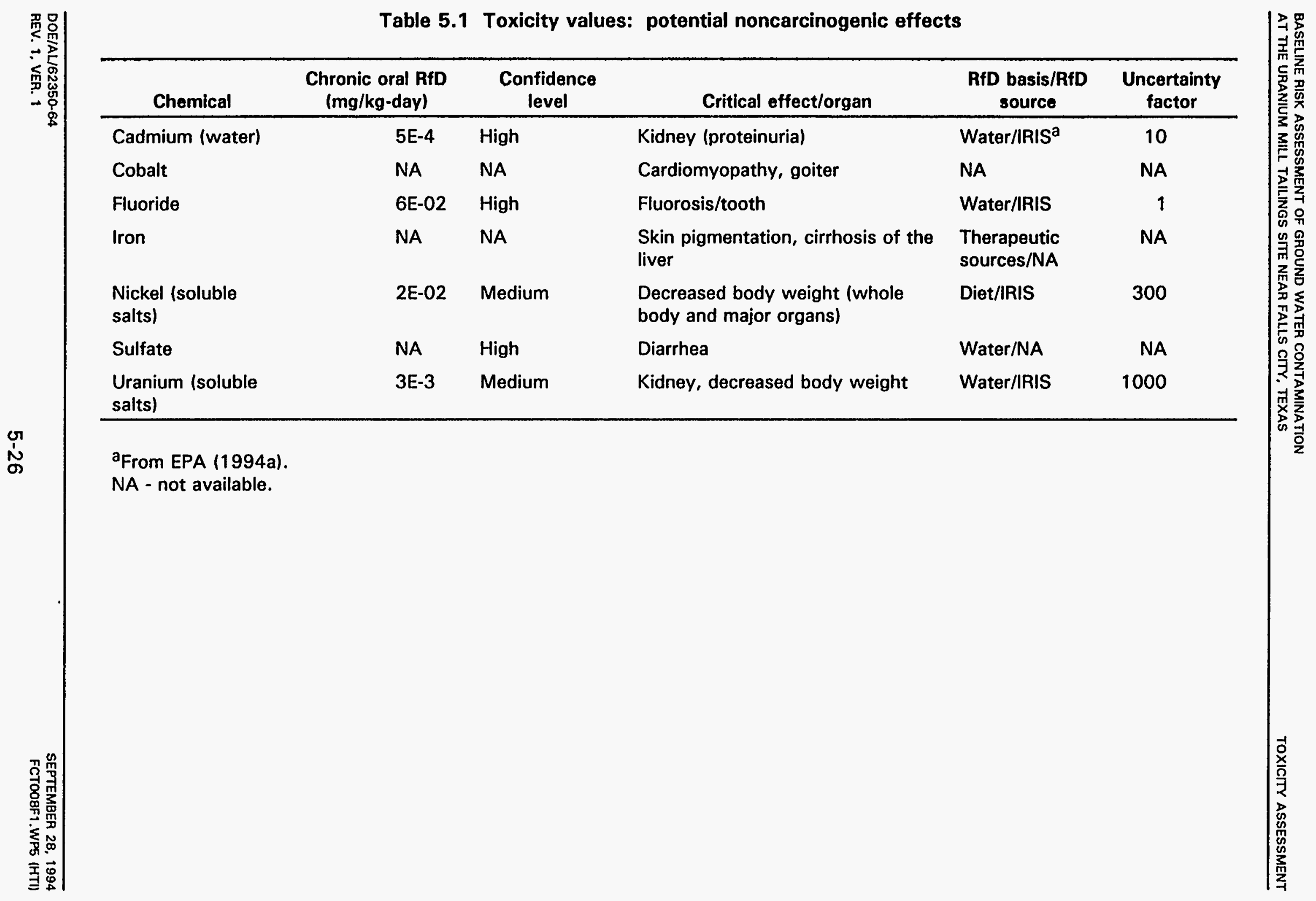




\section{Table 5.2 Toxicity values: potential carcinogenic effects}

\begin{tabular}{|c|c|c|c|c|}
\hline Parameter & $\begin{array}{l}\text { Oral SF } \\
(p C i)^{-1}\end{array}$ & $\begin{array}{c}\text { Weight of } \\
\text { evidence } \\
\text { classification }\end{array}$ & Type of cancer & $\begin{array}{l}\text { SF basis/ } \\
\text { SF source }\end{array}$ \\
\hline Lead-210 & 5.1E-10 & A & Bone & Water/HEAST \\
\hline Polonium-210 & $1.5 \mathrm{E}-10$ & A & Liver, kidney, spleen & Water/HEAST \\
\hline Radium-226 & $1.2 E-10$ & A & Bone & Water/HEAST \\
\hline Thorium-230 & $1.3 E-11$ & A & Bone & Water/HEAST \\
\hline Uranium-238 & $1.6 \mathrm{E}-11$ & A & b & Water/HEAST \\
\hline Uranium-234 & $1.6 \mathrm{E}-11$ & A & b & Water/HEAST \\
\hline
\end{tabular}

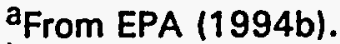

${ }^{b}$ No human or animal studies have shown a definite association between oral exposure to uranium and development of cancer. 


\subsection{HUMAN HEALTH RISK EVALUATION}

To evaluate potential health risks to an individual or population, the results of the exposure assessment for the Dilworth aquifer are summarized for all relevant pathways and combined with the results of the toxicity assessment. As discussed in Section 5.0, potential adverse health effects are a function of how much of the contaminant an individual takes into his or her body. At lower levels, many contaminants associated with the mill tailings are beneficial to health because they are essential nutrients. At higher levels, these same elements can cause adverse health effects or, at very high levels, death. In this section, the estimated reasonable maximum intake, if the Dilworth ground water were used, is correlated to potential health effects. Adult exposure levels are evaluated below for cadmium, cobalt, nickel, and uranium. Exposure levels for children are used to evaluate health risk for fluoride and iron because children are a toxicologically sensitive population. Infants are especially sensitive to sulfate toxicity; therefore, infant exposure is used to evaluate health risks from exposure to sulfate.

For the Deweesville/Conquista aquifer, a qualitative discussion of expected adverse health effects from the potential use of ground water at and near the former uranium processing site and near the site is based on water quality data summarized in Table 3.2. The interpretation of potential adverse health effects presented below applies generally to all age groups.

\subsection{POTENTIAL NONCARCINOGENIC HEALTH EFFECTS}

\subsubsection{Deweesville/Conquista ground water-potential future use}

Uranium minerals in the area of the Falls City site were found primarily in the oxidized, near-surface deposits (generally between 20 to $40 \mathrm{ft}$ deep [6 to $10 \mathrm{~m}$ ]) of the Deweesville/Conquista Formation (Eargle and Weeks, 1961; Bunker and MacKallor, 1973). Due to widely distributed uranium ore deposits, the quality of natural ground water in Karnes County is extremely variable. Within a single formation, the water quality in one stratum may considerably differ from that of another stratum. Within a single stratum, the quality may differ considerably from place to place.

Regional premining data for Karnes County indicate that the quality of ground water in several places (locations not identified) may be too saline for domestic use (Anders, 1962). Most of the ground water used in Karnes County in 1957 (mining began at the end of 1957) was of fair to poor quality. Historically, this water has had limited use because of its high levels of TDS, chloride, magnesium, sulfate, fluoride, iron, calcium, silica, bicarbonate ion, boron, sodium, and manganese.

The Deweesville/Conquista outcrop area near the former mill site contained very little water before milling activity, although significant amounts of naturally occurring ground water may have originally existed farther downgradient in the aquifer. 


\section{Ingestion of ground water}

Reference ground water. Water quality data for the reference ground water from the Deweesville/ Conquista aquifer are compiled from different geographic areas near the Falls City site (Table 3.2). Although the quality of this ground water varies considerably, the EPA maximum contaminant levels and/or secondary levels for some constituents have been exceeded in ground water from all reference locations. These constituents are manganese, nickel, selenium, sulfate, and uranium.

Although the concentrations of some constituents in ground water from on-site cross gradient monitor well 951 and from monitor wells located southeast of the FM 791 are slightly elevated when compared to MCLs, these waters are usable for any purpose based on criteria protective of health. However, if ingested by humans not accustomed to sulfate, especially infants, this water could cause laxative effects.

Due to high concentrations of several toxic constituents (primarily arsenic, lead, uranium and radium-226), adverse health effects could be associated with longterm human consumption (as drinking water) of natural ground water at the Hobson's locations.

Ground water at the former SWI mill site. As discussed in Section 3.1, most if not all of the ground water currently in the outcrop areas of the Deweesville/ Conquista was not present prior to uranium mill operations. The ground water now at the former tailings piles developed during milling activity.

Four sources of potential future human exposure are considered for the Deweesville/Conquista aquifer: the eastern, northern, southern, and western contamination zones (Table 3.2). The most significant adverse health effects would be expected if ground water from these plumes were used as drinking water, even for a relatively short period of time. The contaminants associated with the greatest potential for toxicity are discussed below for each of the plume areas.

Long-term human ingestion of ground water from the eastern region of the Deweesville/Conquista contamination zone could be associated with Parkinsonlike effects and kidney damage from exposure to manganese and uranium, respectively. Sulfate levels in this ground water could cause acute toxicity manifested as severe diarrhea, especially in infants.

If ground water from the northern contamination zone were ingested, severe diarrhea leading to dehydration and possibly death could be expected from sulfate levels, even following short-term exposure. Long-term consumption of this ground water could result in the central nervous system effects from manganese exposure and cirrhosis of the liver from the observed levels of iron. 
Chronic exposure through ingestion of ground water from the southern plume would be expected to result in adverse health effects associated with observed levels of manganese, nitrate, selenium, and sulfate. These effects could range from mild methemoglobinemia (from nitrate levels) and nail and hair brittleness or loss (from selenium levels) to Parkinson-like disease (from manganese levels). Sulfate levels in the ground water could result in diarrhea, even following shortterm exposure.

Chronic exposure to ground water from the western contamination zone could be associated with skin pigmentation and possibly cirrhosis of the liver due to exposure to iron; neurological disorders could be associated with the elevated manganese levels. Selenium levels could cause nail and hair brittleness or loss and sulfate levels could result in diarrhea.

\section{Livestock watering and crop irrigation}

Reference ground water. As reported in 1962, water supplies suitable for watering livestock could be obtained almost everywhere in Karnes County within a depth of $200 \mathrm{ft}(60 \mathrm{~m})$ (Anders, 1962). However, the standards for irrigation water were exceeded frequently in Karnes County (Anders, 1962).

Limited historical ground water quality data from a stock water supply well located within $2 \mathrm{mi}(3 \mathrm{~km})$ southeast of the site (Schafer, 1937) indicate this water could be safely used for livestock watering. However, place-to-place differences may occur with respect to ambient ground water quality in the Falls City site area. These differences are discussed in depth in Section 3.0. Data summarized in Table 3.2 illustrate a broad range of ground water quality from relatively good in the 600 series monitor wells southeast of the FM 791 to naturally very poor water quality from the Hobson wells.

Ground water from monitor wells 667 and 668 appears to be safe for livestock watering; however, manganese and molybdenum at observed levels might affect its continuous use for crop irrigation.

The reference quality water from monitor well 951 also appears to be suitable for stock watering, but if used continuously as irrigation water, this water might adversely affect plants and/or soil due to the manganese and molybdenum concentrations.

The concentrations of iron, boron, manganese, molybdenum, selenium, lead, and arsenic in ground water from the Hobson area limit the potential for watering livestock or crops.

\section{Ground water at the former SWI mill site}

If Deweesville/Conquista contaminated ground water were used for livestock watering, severe toxic effects would be expected in exposed animals because of the high levels of aluminum, sulfate, magnesium, manganese, fluoride, iron, 
molybdenum, and selenium (Table 3.3). Moreover, deposition of some of these elements in animal tissue, milk, or eggs could be harmful to humans who consumed these products.

Excessive concentrations of aluminum, cadmium, fluoride, selenium, sulfate, and vanadium in ground water from the eastern contamination zone could be harmful to domestic animals and possibly to humans consuming animal products. Excessive levels of these constituents and the high content of boron, iron, manganese, molybdenum, and zinc could adversely affect plants and/or soil if the ground water were used for irrigation.

An immediate threat to livestock would be expected from sulfate concentrations in the northern contamination zone if this ground water were used to water stock. Other ground water constituents (aluminum, cadmium, boron, iron, manganese, molybdenum, selenium, vanadium, and zinc) would also affect its usefulness as irrigation water.

Because of its high content of aluminum, cadmium, boron, iron, manganese, molybdenum, selenium, sulfate, and zinc, ground water from the southern contamination zone could be harmful to continually watered livestock and crops.

Ground water from the western contamination zone would not be recommended for continuous livestock and garden watering because of the high levels of boron, iron, manganese, molybdenum, selenium, and sulfate.

\subsubsection{Potential current and future use of the Dilworth ground water}

The results of this assessment of the adult intake doses or the toxicologically most sensitive group are used to evaluate potential adverse health effects for noncarcinogens.

Maximum reasonable exposures from potential use of the Dilworth ground water from the eastern and western contamination zones are evaluated separately for their association with adverse health effects. These zones of contamination of the Dilworth ground water (eastern and western contamination zones) are included in the exposure assessment because potential beneficial uses of ground water from these locations are assumed.

The health risk associated with the Dilworth ground water contamination at the Falls City former mill site is from sulfate and iron levels in the western zone of contamination.

If this water were used for drinking water, sulfate concentrations could produce severe diarrhea, especially in infants (Figure 6.1). The additive contribution of sulfur from ingestion by adults of milk and beef watered with this ground water (20 percent of the drinking water ingestion dose) would not alter the interpretation of health risk. If milk and beef were the only source of an adult's exposure to sulfate, no adverse health effects would be expected. 


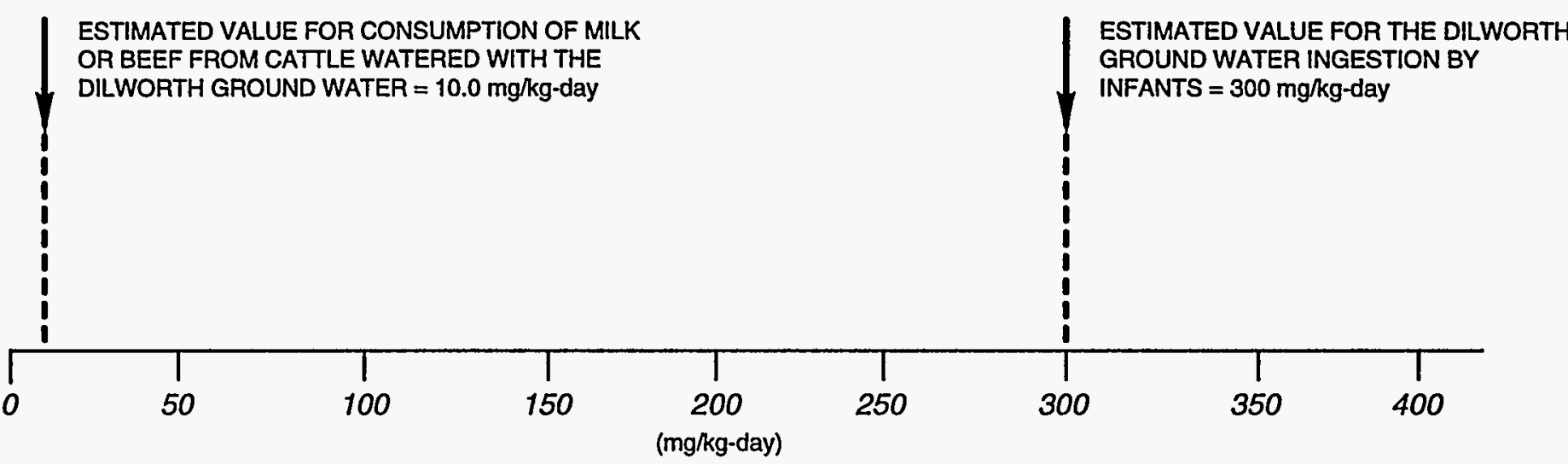

$\sqcup$

BACKGROUND INTAKE LEVELS

NO OBSERERED EFFECTS

MILD TOXICITY RANGING FROM LAXATIVE EFFECT (ADULTS) TO DIARRHEA IN INFANTS

SEVERE TOXICITY - PERSISTENT INFANT DIARRHEA LEADING TO DEHYDRATION $\cdots . . .-$ DEATH

FIGURE 6.1

HEALTH EFFECTS OF ESTIMATED SULFATE EXPOSURE

FROM THE DILWORTH GROUND WATER

FALLS CITY, TEXAS, SITE 
The level of exposure to iron caused by ingesting Dilworth ground water from the western contamination zone would be associated with skin pigmentation and cirrhosis of the liver in children and adults (Figure 6.2).

Exposure levels for cadmium (Figure 6.3) detected in the Dilworth eastern contamination zone and exposure levels for uranium (Figure 6.4) in the western contamination zone exceed the EPA acceptable intake level for both metals if these waters were used as drinking water (RfD of $0.0005 \mathrm{mg} / \mathrm{kg}$-day for cadmium and RfD of $0.003 \mathrm{mg} / \mathrm{kg}$-day for uranium). However, these levels of cadmium and uranium oral intake are below the levels of any observed adverse health effects in humans or animals. The additive contribution of cadmium due to consumption of milk and beef from cattle watered with contaminated ground water (approximately 50 percent of the drinking water dose) would not alter the interpretation of no adverse health effects. The cadmium doses would be in the range of NOAEL of toxicity manifested in proteinuria. Note, however, that the additive contribution of cadmium from ingesting ground water-irrigated produce to the total cadmium intake, which has not been estimated at this time, might alter the interpretation of health risks. Nevertheless, indirect human exposure to cadmium and uranium, only through ingesting beef and milk from cattle that have consumed this ground water (not including the potential contribution from ground water-irrigated feed consumption), is not expected to cause adverse health effects.

The fluoride intake level from ingesting the most contaminated Dilworth ground water (western contamination zone) by children is below the acceptable intake level recommended by EPA (RfD of $0.06 \mathrm{mg} / \mathrm{kg}$-day [Figure 6.5 ]). The additive contribution of fluoride due to consumption of milk and beef from cattle watered with this ground water (20 percent of the drinking water ingestion dose) would not alter the interpretation of health risk. The fluoride doses would be in the NOAEL range for dental mottling in children.

The estimated exposure levels of cobalt and nickel if the Dilworth contaminated ground water were used as drinking water, (Figures 6.6 and 6.7), are within background or dietary intake ranges. However, an interrelationship exists between nickel and cobalt sensitization in individuals exposed to the two metals. Therefore, the combination of nickel sensitivity and irritant eczema may result in a risk for developing an allergy to cobalt under conditions at the Falls City site.

\subsection{POTENTIAL CARCINOGENIC HEALTH EFFECTS}

All uranium isotopes are radioactive and, as such, are considered potential carcinogens. Estimates of potential lifetime carcinogenic risks are based on the cancer SF developed by the EPA; however, natural uranium has not been demonstrated to cause cancer in humans or animals following ingestion. 

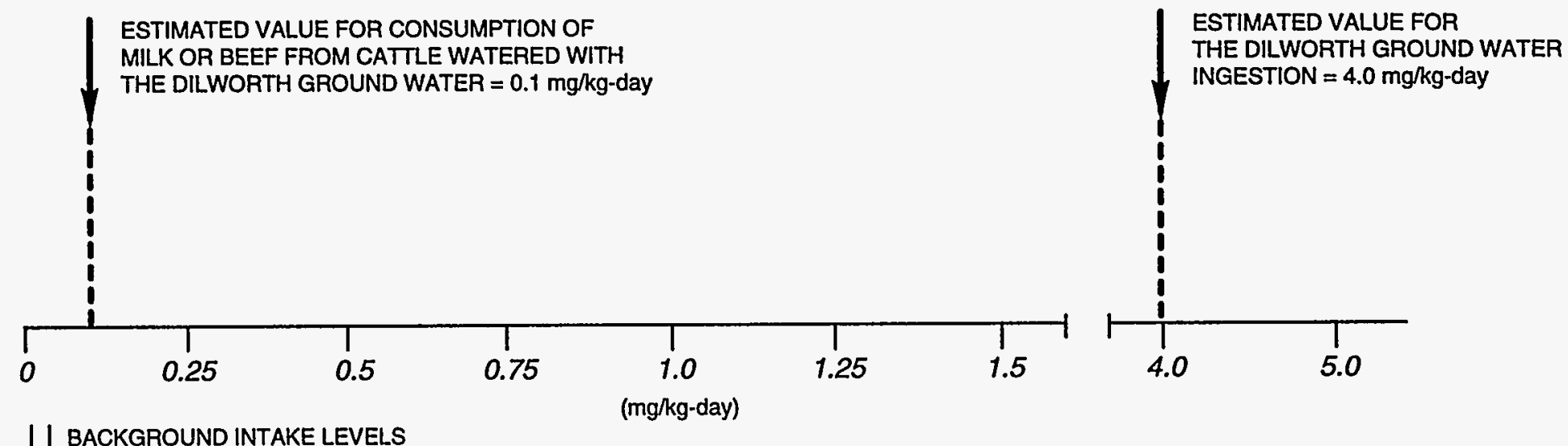

$\downarrow$ BACKGROUND INTAKE LEVELS FROM DRINKING WATER

$$
\text { DIETARY INTAKE LEVELS }
$$

A RDA FOR ADULT MEN (0.14 mg/kg-day)

$\triangle$ RDA FOR ADULT WOMEN (0.25 mg/kg-day)

$$
\begin{aligned}
& \text { INCREASED IRON LEVELS IN ORGANS, SKIN PIGMENTATION, } \\
& \text { LIVER CIRRHOSIS WITH INCREASED DOSES }
\end{aligned}
$$




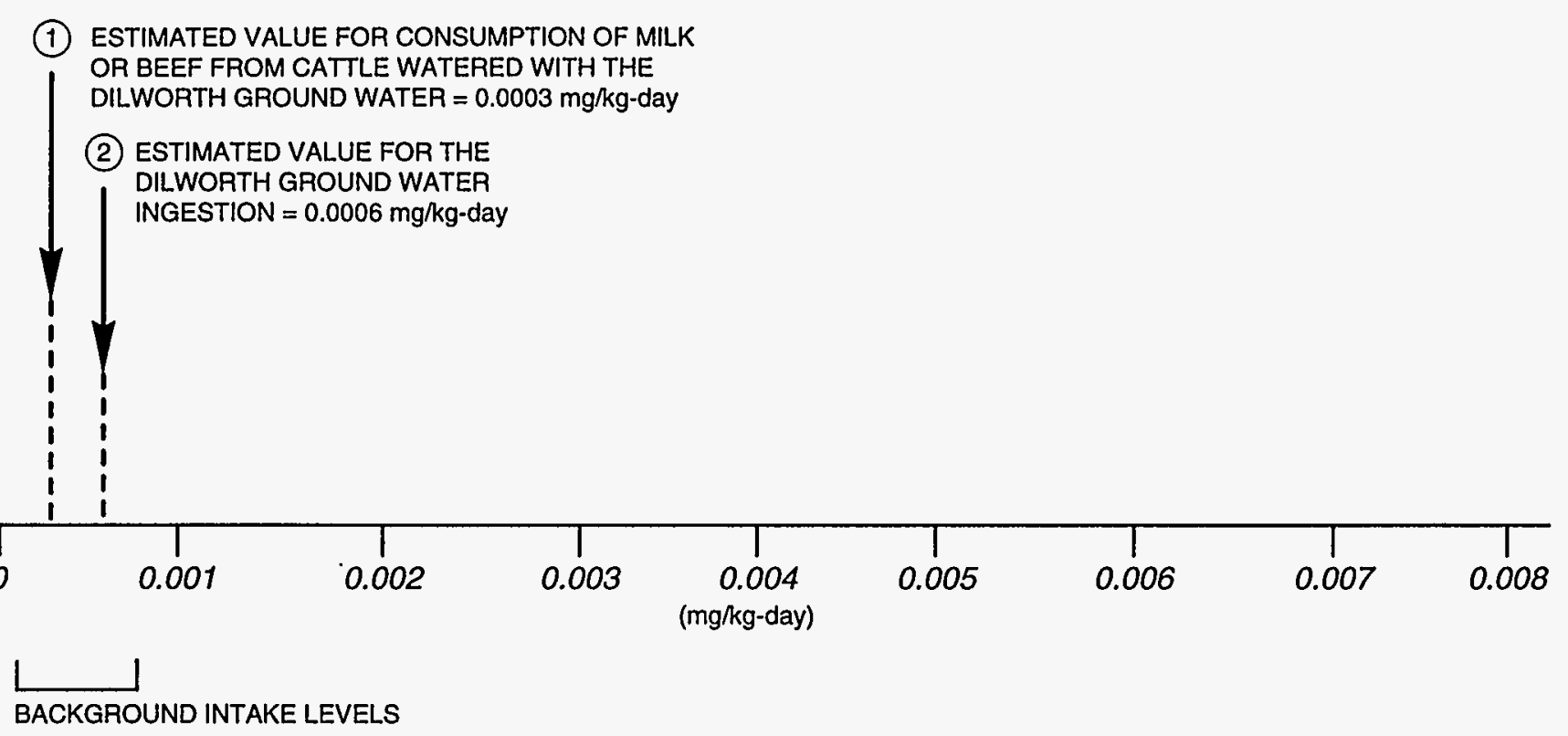

$\triangle$ ORAL REFERENCE DOSE (DRINKING WATER; RfD $=0.0005 \mathrm{mg} / \mathrm{kg}$-day) NO OBSERVED EFFECTS WITH DRINKING WATER CONSUMPTION

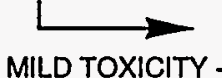

(PROTEINURIA)

FIGURE 6.3

HEALTH EFFECTS OF ESTIMATED CADMIUM EXPOSURE

FROM THE DILWORTH GROUND WATER

FALLS CITY, TEXAS, SITE 


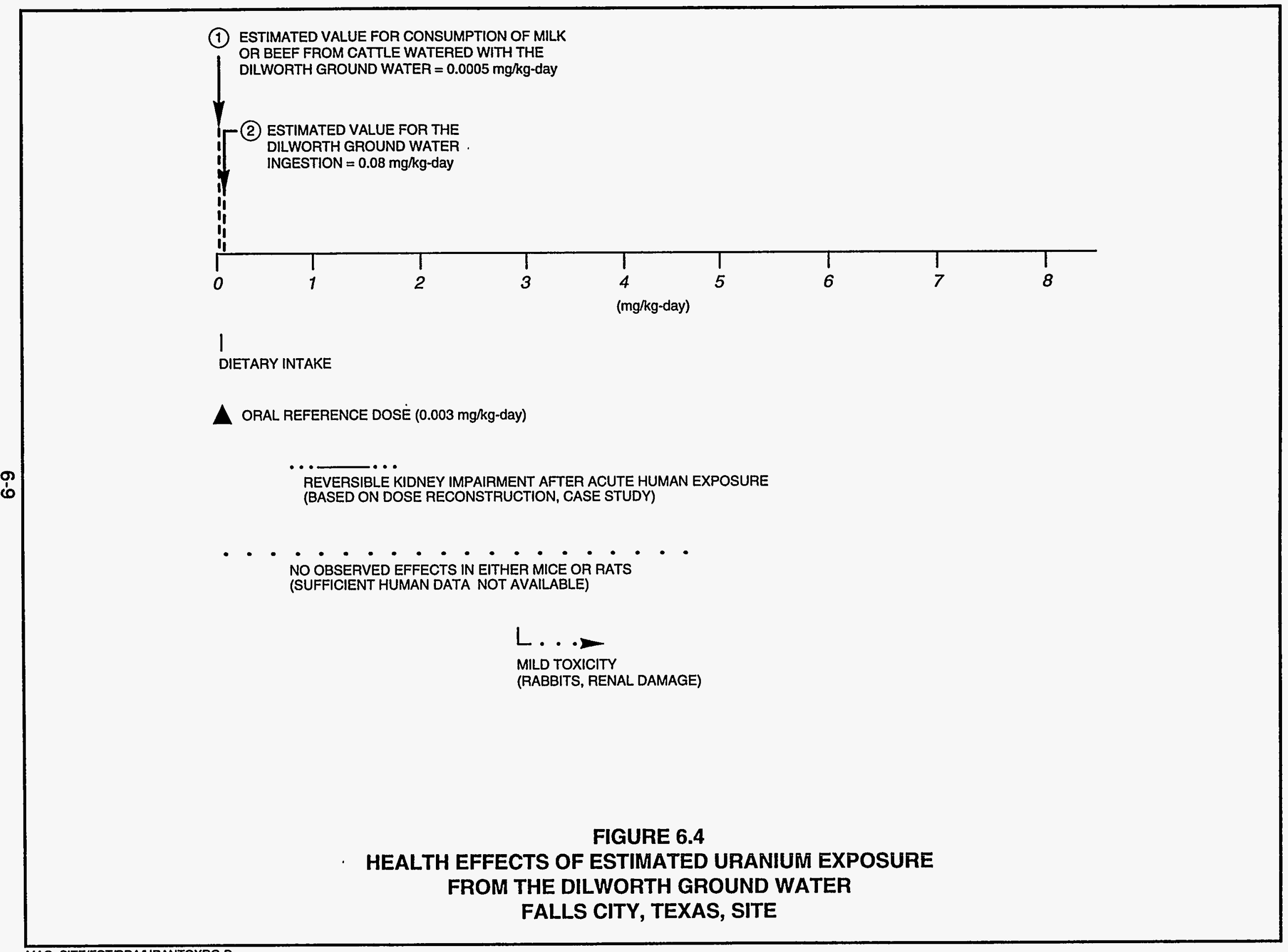


(1) ESTIMATED VALUE FOR CONSUMPTION OF MILK OR BEEF FROM CATTLE

WATERED WITH THE DILWORTH GROUND WATER $=0.007 \mathrm{mg} / \mathrm{kg}$-day

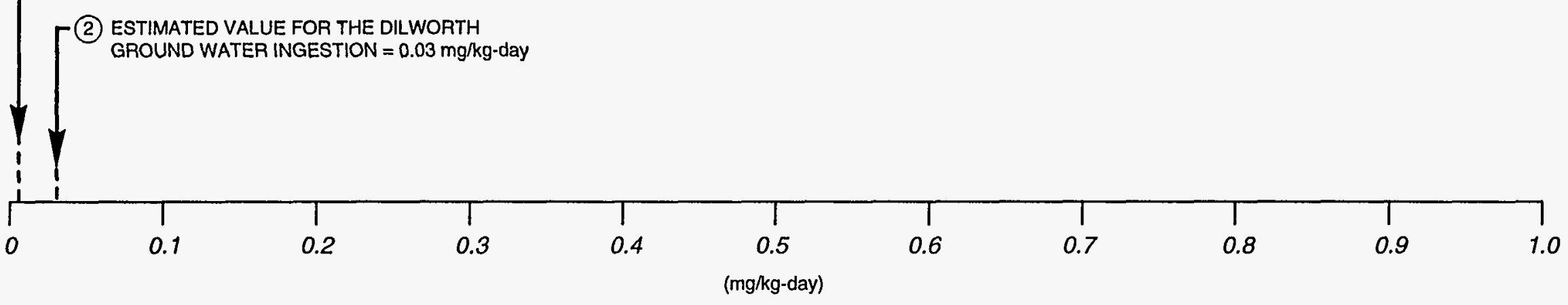

I AVERAGE DIETARY INTAKE LEVEL FROM FOOD

$\ldots-1$

INTAKE LEVELS FROM DRINKING WATER

L

NO OBSERVABLE EFFECT LEVEL FOR DENTAL FLUOROSIS

$\Delta$

ORAL REFERENCE DOSE (FOOD AND DRINKING WATER) $(0.06 \mathrm{mg} / \mathrm{kg}$-day)

0

DENTAL MOTTLING AND CHANGES IN TOOTH STRUCTURE IN CHILDREN - OBJECTIONABLE DENTAL FLUOROSIS

INCREASING DENTAL MOTTLING WITH INCREASING INTAKE IN CHILDREN

NO OBSERVABLE EFFECT LEVEL FOR SKELETAL FLUOROSIS IN ADULTS

CRIPPLING SKELETAL FLUOROSIS IN ADULTS $(0.29-1.1 \mathrm{mg} / \mathrm{kg}$-day)

FIGURE 6.5

HEALTH EFFECTS OF ESTIMATED FLUORIDE EXPOSURE

FROM THE DILWORTH GROUNDWATER

FALLS CITY, TEXAS, SITE 
(1) ESTIMATED VALUE FOR CONSUMPTION OF MILK OR BEEF FROM CATTLE

WATERED WITH THE DILWORTH GROUND WATER $=0.0001 \mathrm{mg} / \mathrm{kg}$-day

(2) ESTIMATED VALUE FOR THE DILWORTH

GROUND WATER INGESTION $=0.003 \mathrm{mg} / \mathrm{kg}$-day

.

1

1

1

if

II

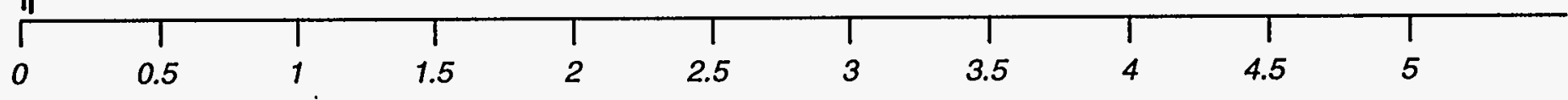

(mg/kg-day)

A NUTRITIONAL REQUIREMENT (0.0002 ug/kg-day)

$\triangle$ BACKGROUND INTAKE FROM DRINKING WATER (0.003 mg/kg-day)

U DIETARY INTAKE $(0.00007-0.0006 \mathrm{mg} / \mathrm{kg}$-day $)$

CARDIOMYOPATHY IN ADULT HUMANS

FIGURE 6.6

HEALTH EFFECTS OF ESTIMATED COBALT EXPOSURE

FROM THE DILWORTH GROUND WATER

FALLS CITY, TEXAS, SITE 


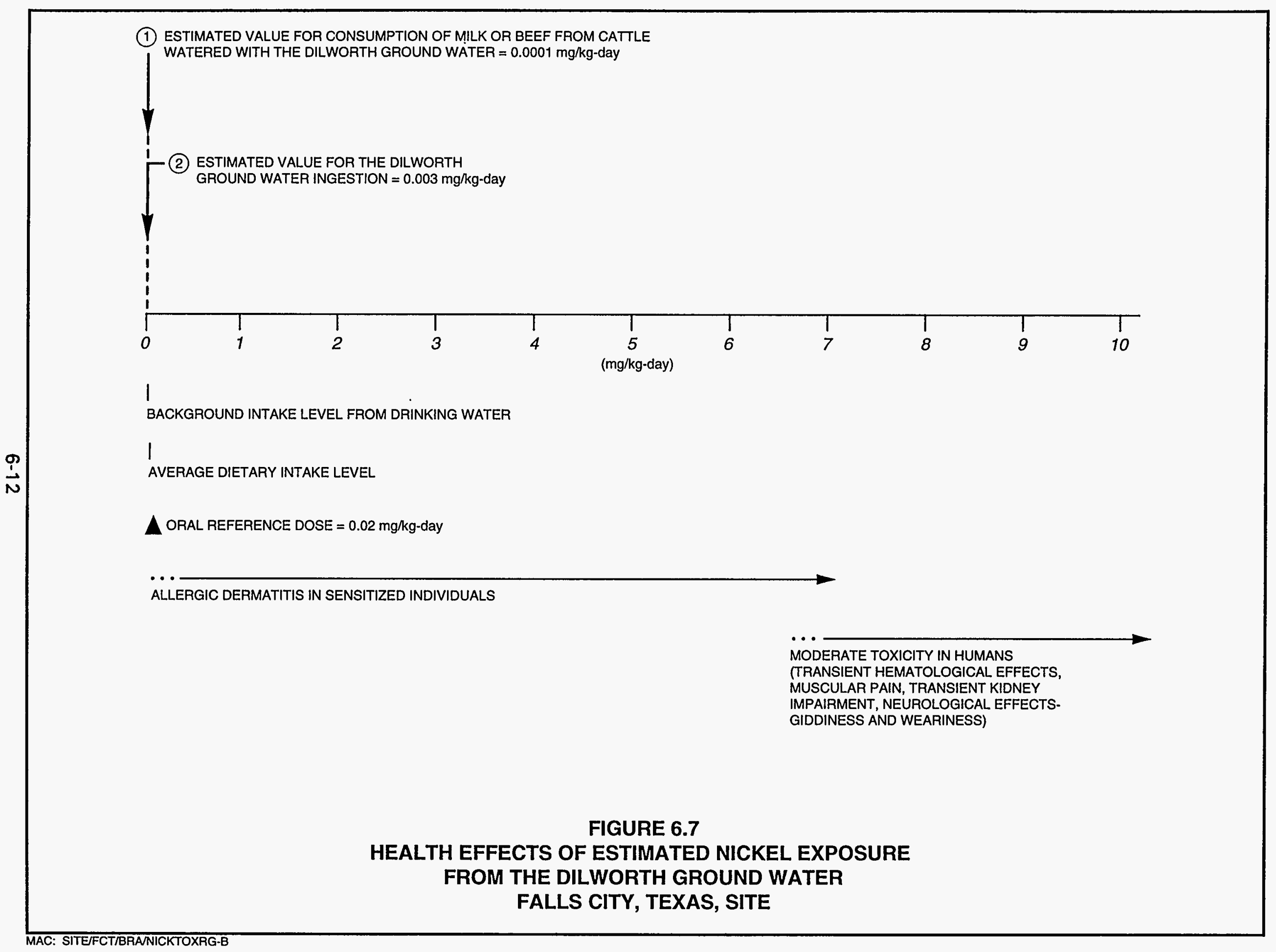




\subsubsection{Deweesville/Conquista potential future use}

If the Deweesville/Conquista reference ground water from certain geographic locations (e.g., from Hobson area) or ground water at the former SWI mill site were used as drinking water or for other beneficial purposes (crop irrigation or stock wateringl, the potential exposure to radioactive uranium and the longerlived radioactive progeny of the uranium decay series could result in an excessive lifetime cancer risk.

Assuming the drinking water ingestion pathway could be completed for the Deweesville/Conquista ground water, exposure to uranium could be associated with a lifetime excess cancer risk as low as 8 in 1,000,000 for the reference water in Conoco monitor wells. For reference ground water near the Hobson production zone, the estimated risk is 4 in 1000. For the Deweesville/Conquista contaminated ground water at the site, the lifetime excess cancer risk from uranium levels ranges from 3 in 1000 (for the southern contamination zone) to 3 in 100 (for the eastern contamination zone).

\subsubsection{Dilworth ground water current and potential future use}

Uranium is the only radionuclide consistently measured in the Dilworth western contamination zone. However, because uranium decays to radioactive progeny, the longer-lived radionuclides of the uranium decay series were evaluated for carcinogenic risk from potential current and future use of the Dilworth aquifer. The estimated carcinogenic risks from exposure to the longer-lived uranium decay products (lead-210, polonium-210, radium-226, and thorium-230) through drinking Dilworth ground water are shown in Table 6.1.

If the Dilworth ground water in the western contamination zone were used as drinking water, the potential lifetime excess cancer risk due to exposure to ionizing radiation from uranium and its longer-lived radioactive progeny is estimated to be 1 in 1000.

The potential lifetime excess cancer risk that may result from ingestion of beef and milk from cattle that had consumed this ground water is estimated at 7 in $1,000,000$ for the western contamination zone and 6 in 10,000,000 for the eastern contamination zone (Table 6.2). For further discussion on the excess lifetime cancer risk, see Section 8.0.

\subsection{LIMITATIONS OF RISK EVALUATION}

The following potential limitations apply to interpretations of this risk evaluation:

- This risk assessment evaluates only risks related to inorganic ground water contamination. Potential contamination by any of the organic constituents used in uranium processing has not been addressed. 


\begin{tabular}{|c|c|c|c|c|c|c|c|c|}
\hline 勇茅 & \multirow[b]{3}{*}{ Radionuclide } & \multirow[b]{3}{*}{$\begin{array}{l}\text { Ingestion SF } \\
(\mathrm{pCi} i)^{-1}\end{array}$} & \multicolumn{6}{|c|}{ Future use } \\
\hline $\begin{array}{r}-8 \\
\$\end{array}$ & & & \multicolumn{3}{|c|}{ Eastern contamination zone } & \multicolumn{3}{|c|}{ Western contamination zone } \\
\hline & & & $\begin{array}{l}\text { Exposure point } \\
\text { concentration } \\
\text { (pCi/L) }\end{array}$ & $\begin{array}{c}\text { Intake } \\
\text { (pCi/lifetime) }\end{array}$ & $\begin{array}{l}\text { Lifetime } \\
\text { risk }\end{array}$ & $\begin{array}{l}\text { Exposure point } \\
\text { concentration } \\
\text { (pCi/L) }\end{array}$ & $\begin{array}{c}\text { Intake } \\
\text { (pCi/lifetime) }\end{array}$ & $\begin{array}{c}\text { Lifetime } \\
\text { risk }\end{array}$ \\
\hline & Lead-210 & 5.1E-10 & 0.8 & 39,200 & $2 E-05$ & NA & NA & NA \\
\hline & Polonium-210 & $1.5 \mathrm{E}-10$ & 0.1 & 4,900 & 7E-07 & NA & NA & NA \\
\hline & Radium-226 & $1.2 \mathrm{E}-10$ & 1.9 & 93,100 & 1E-05 & 2.4 & 117,600 & $1 E-05$ \\
\hline & Thorium-230 & $1.3 \mathrm{E}-11$ & 0.5 & 24,500 & $3 E-07$ & NA & & \\
\hline & $\begin{array}{l}\text { Uranium-234 } \\
\text { and }-238\end{array}$ & $1.6 \mathrm{E}-11$ & 37 & $1,295,000$ & $2 \mathrm{E}-05$ & 2085.4 & $72,989,000$ & $1 \mathrm{E}-03$ \\
\hline דి & Total & & & & $5 \mathrm{E}-05$ & & & $1 \mathrm{E}-03$ \\
\hline 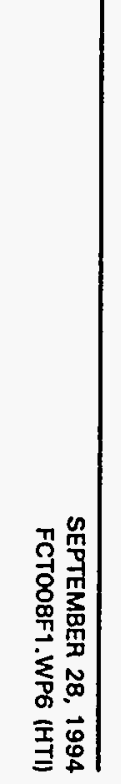 & $\begin{array}{r}\text { Notes: } 1 . \quad \text { Ing } \\
\text { 2. Exp } \\
\text { 3. Exp } \\
\text { NA - data not a }\end{array}$ & $\begin{array}{l}\text { tion rate }-2 \mathrm{~L} \\
\text { sure frequency } \\
\text { sure duration - } \\
\text { ilable. }\end{array}$ & $\begin{array}{l}\text { ay. } \\
0 \text { days per year. } \\
\text { ears. }\end{array}$ & & & . & & \\
\hline
\end{tabular}




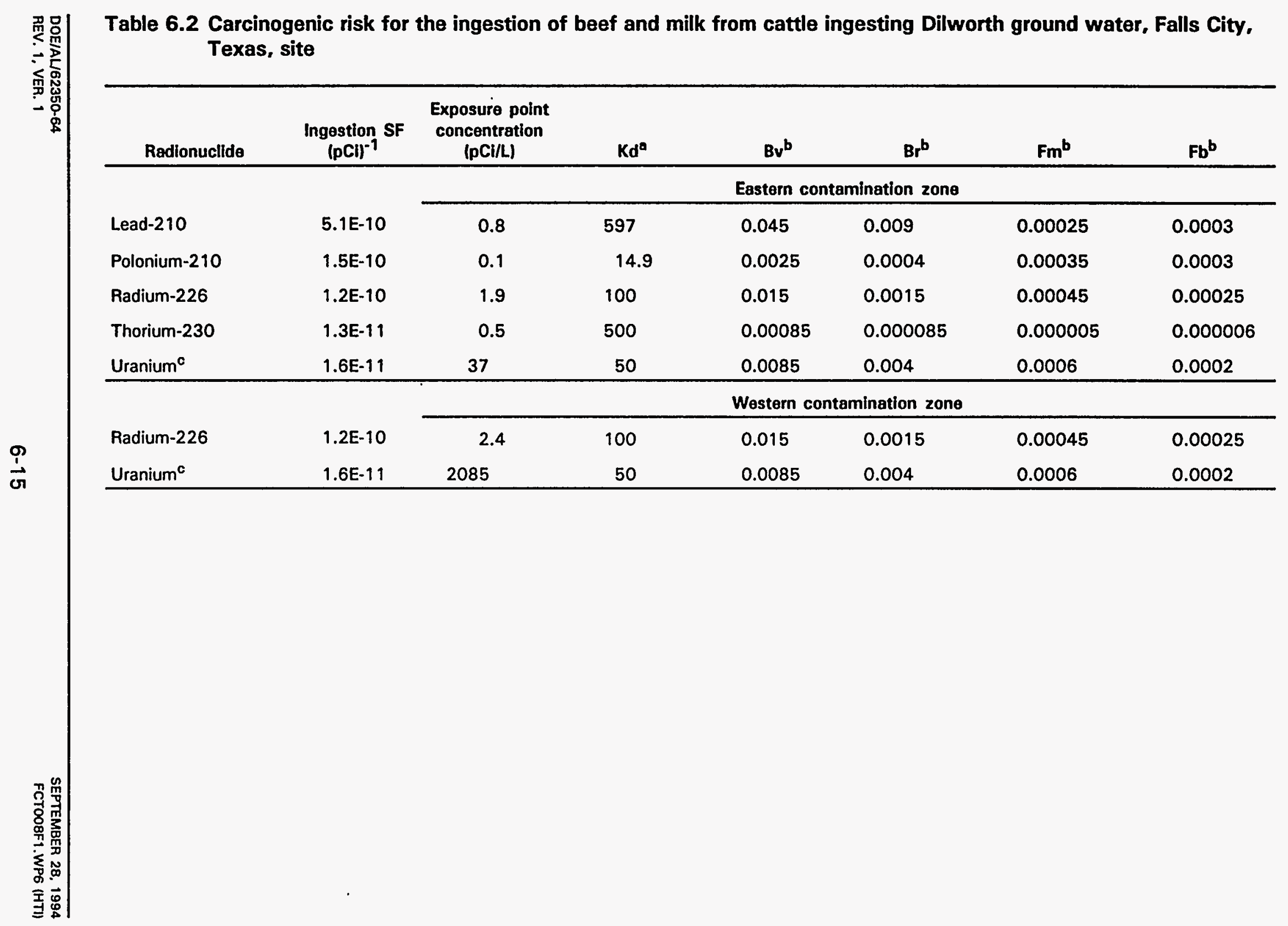


Table 6.2 Carcinogenic risk for the ingestion of beef and milk from cattle ingesting Dilworth ground water, Falls City, Texas, site (Concluded)

\begin{tabular}{|c|c|c|c|c|c|c|}
\hline Radionuclide & $\begin{array}{c}\text { Intake from } \\
\text { ingestion of meat } \\
\text { (pCinifetime) }\end{array}$ & Lifetime risk & $\begin{array}{c}\text { Intake from } \\
\text { ingestion of milk } \\
\text { (pCi/lifetime) }\end{array}$ & Lifetime risk & $\begin{array}{c}\text { Total intake (meat } \\
\text { ond milk) } \\
\text { (pCl/lifetime) } \\
\end{array}$ & $\begin{array}{c}\text { Total llfetime } \\
\text { rlsk }\end{array}$ \\
\hline & \multicolumn{6}{|c|}{ Eastern contamination zone } \\
\hline Lead-210 & 190 & $1 \mathrm{E}-07$ & 620 & $3 \mathrm{E}-07$ & 810 & $4 E-07$ \\
\hline Polonium-210 & 1.8 & $3 E-10$ & 8.6 & $1 \mathrm{E}-09$ & 10.4 & $2 E-09$ \\
\hline Radium-226 & 57 & 7E-09 & 410 & $5 \mathrm{E}-08$ & 467 & $6 \mathrm{E}-08$ \\
\hline Thorium-230 & 0.75 & $1 E-11$ & 2.5 & $3 E-11$ & 3 & $4 E-11$ \\
\hline Uranium $^{a}$ & 610 & $1 \mathrm{E}-08$ & 7300 & $1 \mathrm{E}-07$ & 7910 & $1 \mathrm{E}-07$ \\
\hline \multirow[t]{2}{*}{ Total lifetime risk } & & $1 E-07$ & & $5 E-07$ & & $6 \mathrm{E}-07$ \\
\hline & \multicolumn{6}{|c|}{ Western contamination zone ${ }^{d}$} \\
\hline Radium-226 & 72 & $9 \mathrm{E}-09$ & 520 & $6 \mathrm{E}-08$ & 592 & 7E-08 \\
\hline Uranium $^{c}$ & 34,000 & $5 \mathrm{E}-07$ & 410,000 & 7E-06 & 444,000 & 7E-06 \\
\hline Total lifetime risk & & $5 E-07$ & & 7E-06 & & 7E-06 \\
\hline
\end{tabular}

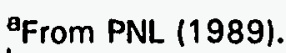

brom Baes et al. (1984).

Uranium-234 and uranium-238 combined; $1 \mathrm{mg}$ uranium is assumed to equal $686 \mathrm{pCi}$.

dOther than radium-226, longer-lived uranium decay series have not been analyzed for in the western contamination zone monitor well ground water. 
- Subpopulations that might have increased sensitivity (such as diabetics or the elder(y) are not specifically addressed. Similarly, some individuals may be more sensitive to the toxic effects of certain constituents for reasons that have not been determined.

- Data available to interpret potential adverse health effects are not always sufficient to allow accurate determination of all health effects (i.e., lack of testing in humans or testing of dose ranges other than those expected at this site).

- Although plume movement is evaluated hydrologically and geochemically, the ground water monitoring locations may not be in the most contaminated areas of the contamination zone.

- The drinking water exposure pathway was considered in depth and the dermal pathway was screened. The garden produce pathway will require evaluation as data become available. Beef and milk exposure pathways were not evaluated for ingestion of ground water-irrigated feed.

The evaluation presented here has considered these limitations and compensated when possible with the use of toxicity ranges rather than point estimates to address some of the variability. The impact of these potential limitations is discussed more fully in Section 8.2. 


\subsection{LIVESTOCK AND ENVIRONMENTAL EVALUATION}

The objective of this section is to assess the potential for site-related contaminants to adversely affect 1) the existing biological communities and 2) livestock grazing and other agricultural practices in the site area. The EPA has no current guidance for quantifying potential ecological impacts of the release of hazardous constituents; the EPA has, however, developed a qualitative approach to be used in ecological risk evaluations (EPA, 1989b). As part of this qualitative approach, the EPA recommends that ecological assessments be conducted in a phased approach to ensure the most effective use of resources while at the same time conducting all necessary work (EPA, 1992b). This approach consists of four phases: identification of potentially exposed habitats (phase 1), the collection of chemistry data (phase 2), collection of biological samples (phase 3), and conducting toxicity testing (phase 4). If the initial inspection of the habitats and the analysis of media samples indicate that little or no potential for ecological risk, the assessment will likely be complete. If the early phases of the assessment indicate the contaminants may be adversely affecting ecological receptors, a higher level of analysis may be warranted.

The ecological risk assessment at the Falls City site consists of the first three phases of the EPA approach, because there is a potential that habitats have been impacted (phase 1) and water chemistry data collected for a few years are available (phase 2). The existing water quality data for the last few years, plus additional limited sediment, plant, and fish data (phase 3), were used to prepare this assessment. This qualitative approach provides a screening level assessment of the risks associated with potential exposure to contaminated media at the site.

It is often difficult to determine if contaminants have affected the biological component of an ecosystem and to predict whether observed effects will result in damage to the ecosystem. However, although determining effects of a contaminant on the ecosystem may be difficult, sampling environmental media such as surface water can help assess potential ecological risk. For such an ecological risk to occur, a source of contamination must exist and there must be a pathway for this contamination to reach the biological communities. The following sections identify areas of contamination and their potential pathways into the aquatic and terrestrial biological communities at the Falls City site, the potential ecological receptors at the site, the contaminants of potential concern, and how these potential contaminants of concern threaten ecological resources, livestock, and agricultural crops.

\subsection{EXPOSURE CHARACTERIZATION}

The potential exposure pathways associated with this site are identified below. Exposure occurs when there are both a source of contamination and a mechanism of transport (pathway) to a receptor population or individual. 
The tailings piles and associated contaminated soils are stabilized permanently in an on-site disposal cell. Therefore, the following direct exposure pathways will not be evaluated in this baseline risk assessment:

- Incidental soil ingestion.

- Dermal contact with soil.

- Inhalation of air containing particulates.

However, the direct exposure pathways associated with ground water or surface water listed below are potential pathways at the site and are evaluated in this document:

- Ingestion of surface water potentially affected by contaminated ground water.

- Bioconcentration of contaminants in surface water by aquatic organisms.

- Indirect exposure pathways.

- Consumption of previously exposed organisms (bioaccumulation).

The net accumulation by organisms of a constituent directly from the surrounding environment is known as bioconcentration. Net accumulation by organisms as a result of all routes of exposure, including the diet, is known as bioaccumulation. Generally, bioconcentration measures chemical uptake from water by aquatic organisms. Soil bioconcentration factors (BCF) are too variable and dependent on site conditions to make identification of generic soil BCFs possible. Freshwater fish BCFs in the scientific literature for the constituents detected in surface waters in the site vicinity range from 2 liters per kilogram $(\mathrm{L} / \mathrm{kg})$ for uranium to $100 \mathrm{~L} / \mathrm{kg}$ for iron (NUREG, 1986; EPA, 1992c). Fish BCFs are not available for some of the constituents. Significant fish BCF values range from 1000 to $300 \mathrm{~L} / \mathrm{kg}$ (Kenaga, 1980; EPA, 1989b). None of the constituents detected in the surface waters in the site vicinity are considered significant; the fish tissue data collected from the site vicinity support this determination (see Section 7.4.2).

Several intermittent streams are located in the immediate vicinity of the former tailings site (Figure 7.1). South of the site, Tordilla Creek drains toward the southwest and eventually into Borrego Creek to the Atascosa River. Northeast of the site, Scared Dog Creek drains toward the San Antonio River. Several ponds are also located in the site vicinity (Figure 7.1). Small wet areas occur at the western edge of a pond east of former pile 3 and along Tordilla Creek (Figure 7.1).

Resident aquatic life, terrestrial wildlife, and domestic animals could be exposed to contaminants in surface water and/or sediments in these areas. Although 


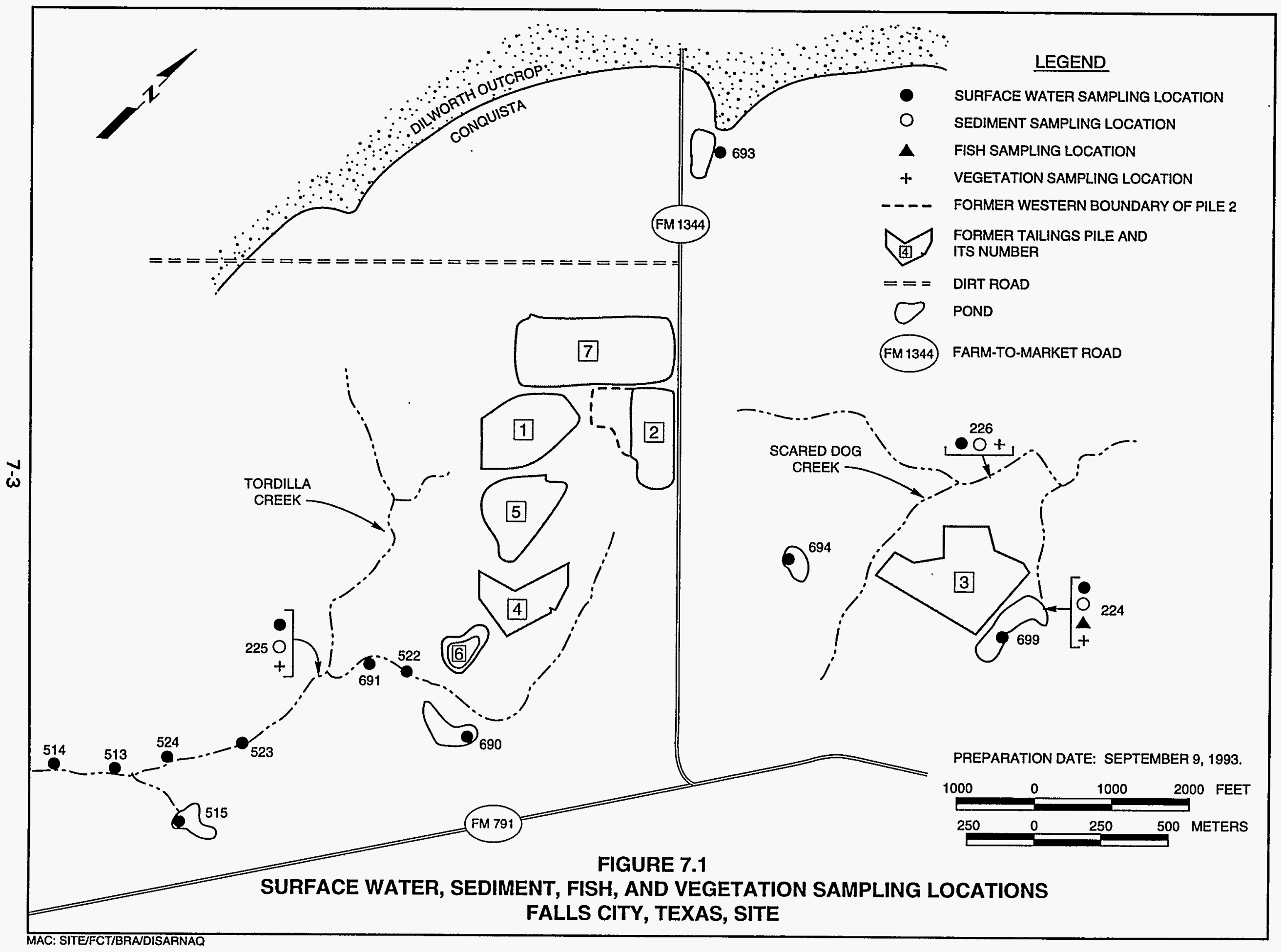


there is no indication that the ponds are affected by the former uranium mill activity, these exposure pathways are evaluated in this risk assessment.

One potential current pathway includes plant uptake of constituents from potentially affected media (ground and surface water, sediments). Plant samples were collected from three locations in the site vicinity. The results of these analyses are evaluated in this risk assessment.

Another potential pathway is the use of ground water for livestock or for agriculture. Available information indicates no wells access the Deweesville/Conquista as a source of water for livestock or irrigation. However, this baseline risk assessment conservatively assumes that in the future, a domestic well could intercept the most contaminated ground water in the Deweesville/Conquista. Water from this hypothetical well could be used in a livestock watering pond (which could also be stocked with fish) or to irrigate agricultural crops. Ground water from the Dilworth has been used to water livestock and gardens.

\subsection{ECOLOGICAL RECEPTORS}

The ecological resources at the site and vicinity that are potentially exposed to site-related contaminants are identified below.

The Falls City site is within the Mesquite-Granjeno woods in the South Texas Plains (McMahan et al., 1984). The plains are dominated by subtropical dryland vegetation and encompass approximately 20 million ac ( 8 million ha) from San Antonio south to the Gulf Coast. During the last 100 years, many areas that were once grasslands with low mesquite shrubs have become dominated by mesquite and other brush species. The main reason for this shift has been the suppression of fires (Johnston, 1963).

Information regarding the flora and fauna at the Falls City site was derived from field reconnaissance surveys summarized in the site environmental assessment (DOE, 1991), consultations with natural resource personnel from state and federal agencies, and review of pertinent literature.

\subsubsection{Plant communities and wildlife}

The following five plant community types were observed on and directly adjacent to the Falls City site:

- Grass-dominated.

- Cleared pastureland.

- Mesquite-shrubland. 
- Disturbed areas.

- Wet areas and associated vegetation.

Eleven species of reptiles and amphibians were observed at or near the Falls City site, with unconfirmed reports of two additional species. Species such as the western diamondback rattlesnake, western ribbon snake, yellow-bellied water snake, ornate box turtle, three-toed box turtle, leopard frog, and bullfrog were observed on or near the site.

Seventy-seven species of birds were observed at or near the Falls City site. Fifty-two of these species nest in the site area, while the remaining species either migrate or nest away from the site. The mesquite-shrubland habitat has the most diverse bird community with 48 species recorded. Species commonly observed include the mockingbird, cardinal, bobwhite, Bewick's wren, and mourning dove. Twenty-six species of birds were observed at the ponds on or near the tailings piles. Migrant species include the greater yellow-legs, dowitcher, and pectoral sandpiper. Water birds that may nest in the region include herons (green-backed, little blue, and great blue) and waterfowl (bluewinged teal, fulvous whistling duck, and black-bellied whistling duck). It is unlikely that colonial nesting herons nest at or near the site since no heronries were reported in the three-county area around the site (Texas Colonial Waterbird Society, 1982) and none were observed during site visits. Ducks probably nest within the three-county area; however, the habitat around the ponds is not appropriate for waterfowl nesting due to lack of brood cover.

A total of 11 species of mammals were observed at the Falls City site and at least an additional 16 species may occur at the site. The coyote was the only large predator recorded. The white-tailed deer is the only large wild herbivore that occurs on the site. Its tracks and droppings were evident throughout the site and were most common in the mesquite-shrublands and along fence rows and senderos. Aquatic mammals such as the muskrat were not observed at the site ponds.

The major game species observed on or near the site were the bobwhite quail, mourning dove, wild turkey, cottontail rabbit, and white-tailed deer. The bobwhite quail and mourning dove are common breeding birds at and around the Falls City site, while the wild turkey is less common. Cottontail rabbits and white-tail deer are common.

\subsubsection{Threatened and endangered species}

Consultation with the state of Texas indicated that 19 species of threatened and endangered species may occur in the area of the Falls City site. Analysis of the distribution and habitat requirements of these 19 species indicates the Texas tortoise, Texas horned lizard, and Texas indigo snake could occur in the site area; the Texas horned lizard was encountered during surface remediation at the site. 
The distribution of the Texas tortoise has not been accurately determined. However, the presence of this species has been confirmed in Wilson, Karnes, and Atascosa Counties (Rose and Judd, 1982; Strecker and Johnson, 1935). The species occurs in upland open mesquite-shrubland habitat and is closely associated with prickly pear cactus, on which it feeds extensively and which it uses for escape cover (Rose and Judd, 1982). Mesquite-shrubland habitat occurs in many areas adjacent to the Falls City tailings piles. Prickly pear is very common in some of these areas and is more widely scattered in others. A total of 293 ac (119 ha) of habitat were searched for the Texas tortoise in 1987, and 99 ac (40 ha) in 1990. No Texas tortoises were observed during these surveys; the only reptiles recorded were the ornate box turtle, three-toed box turtle, Texas spotted whiptail, western ribbon snake, and western diamondback rattlesnake. These observations indicate the Texas tortoise does not occur or occurs at very low densities at the Falls City site.

The Texas horned lizard has a wide distribution within the state and its presence has been confirmed in Atascosa and Wilson Counties (Raun and Gehlbach, 1972). It occurs in flat, open terrain and may occur at or near the Falls City site. This species was not observed using site-specific surveys (DOE, 1991) but was observed during surface remediation of the site.

The Texas indigo snake is the largest snake in Texas, with individuals more than $8 \mathrm{ft}(3 \mathrm{~m})$ long recorded. The species occurs in a variety of habitats ranging from grassy areas to mesquite-shrublands; the mesquite-shrublands known as the South Texas thorn woodlands are its preferred habitat (Tennant, 1984). The species has been recorded in Atascosa County. The Falls City site appears to be on the eastern boundary of the snake's range (Tennant, 1984; Raun and Gehlbach, 1972). This species was not observed at the Falls City site; however, given the presence of suitable habitat at the site and the snake's known distribution, the snake may occur near the site.

\subsubsection{Aquatic organisms}

No field reconnaissance surveys or inventory of the aquatic organisms potentially occurring in the site vicinity have been conducted. Channel catfish have been stocked in the pond east of the former pile 3. However, no survey of aquatic life in the other ponds and intermittent drainages (e.g., Tordilla Creek, Scared Dog Creek) has been conducted in the site vicinity.

\subsection{CONTAMINANTS OF ECOLOGICAL CONCERN}

During an environmental risk evaluation the constituents detected in each media are screened for their potential to represent a concern to ecological receptors. One of these screening processes involves comparing the concentrations to background concentrations. The list of ground water contaminants that exceeded background in the Dilworth aquifer (Table 3.4) and the three constituents in the Deweesville/Conquista aquifer that were used to assess the 
risk to human health also were used to evaluate the ecological receptors potentially exposed to ground water (e.g., livestock).

No site-specific background locations for the other media (surface water, sediment, vegetation, and fish) were sampled as part of site characterization. Therefore, all the constituents detected in these media are included in the evaluation. However, because it has not been determined whether the detected concentrations are elevated above site-specific background concentrations, they will not be referred to as contaminants of potential concern.

\section{$7.4 \quad$ POTENTIAL IMPACTS TO WILDLIFE AND PLANTS}

\subsubsection{Terrestrial risk}

Vegetation. By ingesting plants that may have bioaccumulated certain contaminants, foraging wildlife may be indirectly exposed to contaminants in ground water. Direct exposure by terrestrial wildlife to contaminants in surface water bodies may occur through ingestion of the surface water and aquatic organisms and incidental sediment ingestion. However, accurate data on generic BCFs for terrestrial wildlife are not available in the scientific literature.

Vegetation was evaluated as a potential exposure pathway and as a receptor. Vegetation can be directly exposed to constituents in media (ground water, surface water, and sediment) through root uptake. Constituents may accumulate in various plant parts to exert a wide range of influences, depending on the specific constituent. Plant uptake rates vary greatly among species and are affected by factors such as soil characteristics $(\mathrm{pH}$, moisture, redox potential, organic matter), plant sensitivity, input-output balance, and cumulative effects.

Vegetation samples collected from three site-vicinity locations on January 28, 1993, were analyzed for aluminum, antimony, arsenic, cadmium, chromium, molybdenum, selenium, uranium, and vanadium. Water hyacinth was collected from the fringe of the pond east of the former pile 3 (location 224), sedge from Tordilla Creek (location 225), and an unidentified aquatic plant from Scared Dog Creek (location 226) (Figure 7.1). The sedge collected from Tordilla Creek requires moist soil conditions. However, it is not considered an aquatic plant, as are those collected from the other two locations. No samples of plants that require drier soil conditions (e.g., grasses, shrubs) were collected for site characterization.

The following constituents were detected in the plant samples: aluminum, arsenic, chromium, molybdenum, selenium, uranium, and vanadium (Table 7.1). With the exception of arsenic, the highest concentration for each constituent was detected in the sample collected from Tordilla Creek. The detected concentrations were compared to background concentrations reported in the literature for aquatic vegetation. It should be noted that the background concentrations reported in Table 7.1 are from locations across the United 
Table 7.1 Occurrence of constituents detected in vegetation collected from water bodies in the site vicinity, Falls City, Texas, site

\begin{tabular}{|c|c|c|c|c|}
\hline \multirow[b]{2}{*}{ Constituent } & \multirow{2}{*}{$\begin{array}{c}\begin{array}{c}\text { Pond east of the } \\
\text { former pile } 3\end{array} \\
\text { Location ID } 224\end{array}$} & \multirow{2}{*}{$\frac{\text { Tordilla Creek }}{\text { Location ID } 225}$} & \multirow{2}{*}{$\frac{\text { Scared Dog Creek }}{\text { Location ID } 226}$} & \multirow{2}{*}{$\begin{array}{l}\text { Background concentrations } \\
\text { reported in literature }\end{array}$} \\
\hline & & & & \\
\hline Aluminum & 5060 & 6300 & 4990 & NA \\
\hline Arsenic & 33 & 11.5 & 11.6 & $1.4-13$ \\
\hline Chromium & 2.4 & 2.8 & 1.3 & NA \\
\hline Molybdenum & 5.5 & 10 & 3.0 & $0.4-2.5$ \\
\hline Selenium & 0.64 & 1.3 & 0.74 & $0.1-0.4$ \\
\hline Uranium & 5.8 & 37.5 & 17.6 & NA \\
\hline Vanadium & 8.2 & 22.1 & 9.8 & NA \\
\hline
\end{tabular}

a Natural background concentrations reported in aquatic plants (Eisler, 1985a; 1988; 1989).

NA - not available.

Concentrations reported in milligrams per kilogram dry weight. 
States, and may not be representative of site-specific or local conditions. However, they can provide a general indication of conditions at the site relative to other areas.

No background data were found in the available literature for aluminum and chromium concentrations in aquatic plants. The sample from the pond east of the former pile 3 shows arsenic concentrations above the upper value of the background range, while the concentrations in the samples from Tordilla Creek and Scared Dog Creek were within the background range (Table 7.1). Molybdenum and selenium concentrations in the samples from all three locations were above their respective background ranges. However, data are not available to determine if these concentrations represent a phototoxic concern.

Bioaccumulation in terrestrial organisms as a function of constituents present in ingested plants or animals (e.g., birds eating fish) is a potential exposure pathway at the site. Birds and other vertebrates consuming these plants and animals can bioaccumulate some constituents from their diet if the amount ingested exceeds the amount eliminated. This factor is often a function of the areal extent of contamination versus the areal extent of the animals' feeding range. In small contaminated areas, the amount of food in the animals' diet usually exceeds the impacted food and bioaccumulation is not a concern. Therefore, exposure through the diet for all trophic-level species is possible in certain areas (e.g., the pond east of the former pile 3), but the potential for bioaccumulation is not always a concern. The available tissue data from plants and fish collected in the site vicinity do not indicate conclusively that bioaccumulation is occurring or if it could result from site-related contamination.

Biomagnification is a more severe condition, in which the concentration of a constituent increases to higher levels of the food chain because the constituent concentrations accumulate through each successive trophic level. Biomagnification is of particular concern for the top predators, especially carnivorous birds and mammals. Only a limited number of constituents have the potential to magnify in the food chain. Most constituents are metabolized and eliminated at each level of the food chain. Thus, the constituent concentration does not increase up the food chain.

Ground water. To evaluate the potential impact of using contaminated ground water from the two aquifers in a livestock pond might have on wildlife (i.e. animals drinking from the pond or fish stocked in the pond), the 95-percent upper confidence limit (UCL) ground water concentrations for the constituents were compared to available water quality values. This comparison is shown in Table 7.2 for Deweesville/Conquista ground water and in Table 7.3 for Dilworth ground water. No federal or state criteria or standards protect terrestrial wildlife from exposure contaminated water, making it difficult to evaluate the potential hazards to terrestrial receptors. However, available surface water quality values for the protection of freshwater aquatic life do exist, including the Texas Water Commission (TWC) criteria (TWC, Section 307.6). 


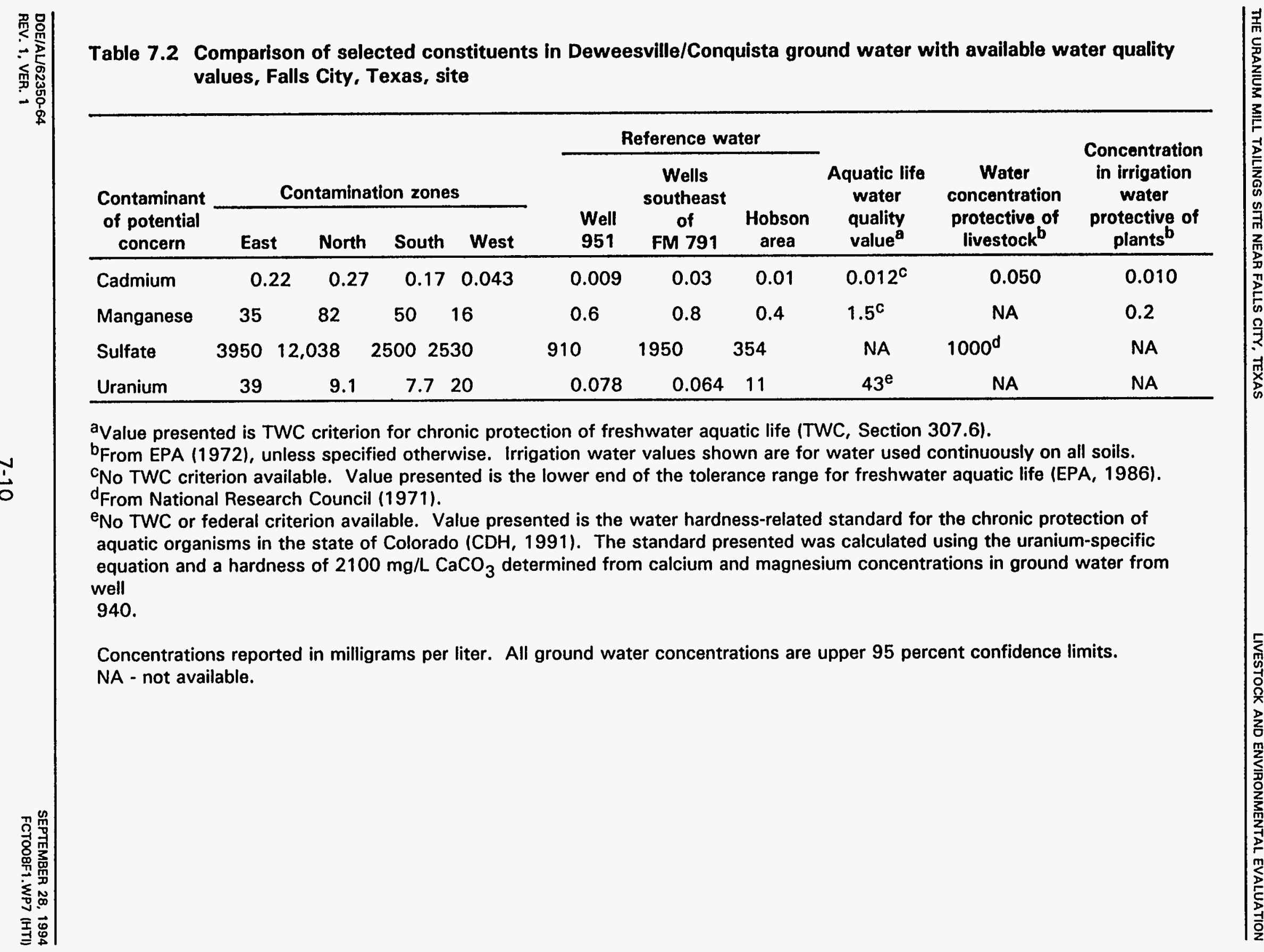


Table 7.3 Comparison of contaminants of potential concern in Dilworth ground water with available water quality values, Falls City, Texas, site

\begin{tabular}{|c|c|c|c|c|c|}
\hline $\begin{array}{c}\text { Contaminant of potential } \\
\text { concern }\end{array}$ & $\begin{array}{c}\text { Eastern } \\
\text { contamination zone }\end{array}$ & $\begin{array}{c}\text { Western } \\
\text { contamination } \\
\text { zone }\end{array}$ & $\begin{array}{l}\text { Aquatic life water } \\
\text { quality value }^{\mathbf{B}}\end{array}$ & $\begin{array}{c}\text { Water } \\
\text { concentration } \\
\text { protective of } \\
\text { livestock }^{\mathbf{b}}\end{array}$ & $\begin{array}{c}\text { Concentration in } \\
\text { irrigation water } \\
\text { protective of } \\
\text { plants }\end{array}$ \\
\hline Aluminum & 0.71 & 1.0 & $0.991^{c}$ & 5.0 & 5.0 \\
\hline Ammonium & NAB & 5.7 & NCA & NCA & NCA \\
\hline Cadmium & 0.022 & NAB & $0.006^{d}$ & 0.050 & 0.010 \\
\hline Cobalt & 0.09 & 0.08 & NCA & 1.0 & 0.05 \\
\hline Fluoride & NAB & 1.0 & NCA & 2.0 & 1.0 \\
\hline Iron & NAB & 127 & $1.0^{\mathrm{e}}$ & NCA & 5.0 \\
\hline Nickel & 0.11 & 0.09 & $0.95^{d}$ & NCA & 0.20 \\
\hline Sulfate & 1580 & 1930 & NCA & $1000^{f}$ & NCA \\
\hline Uranium & NAB & 3.0 & $16^{g}$ & NCA & NCA \\
\hline Zinc & 0.21 & 0.21 & $0.64^{d}$ & 25 & 2.0 \\
\hline
\end{tabular}

a Values presented are TWC criteria for chronic protection of freshwater aquatic life (TWC, Section 307.6), unless specified otherwise.

TWC criteria are for dissolved (filtered) metals in water.

${ }^{b}$ From EPA (1972), unless specified otherwise. Irrigation water values shown are for water used continuously on all soils.

${ }^{C}$ No chronic TWC criteria available. Value shown is the acute TWC criterion.

${ }^{d}$ Water hardness-dependent TWC criterion (TWC, Section 307.6). Criterion presented was calculated using a constituent-specific equation and a hardness of $840 \mathrm{mg} / \mathrm{L} \mathrm{CaCO}_{3}$ determined from calcium and magnesium concentrations in ground water from well 977.

e No TWC criterion available. Value shown is the chronic Federal Water Quality Criterion (EPA, 1986).

fFrom National Research Council (1971).

9No TWC or federal criterion available. Value presented is the water hardness-related standard for the chronic protection of aquatic organisms in the state of Colorado $(\mathrm{CDH}, 1991)$. The standard presented was calculated using the uranium-specific equation and a hardness of $840 \mathrm{mg} / \mathrm{L} \mathrm{CaCO}_{3}$ determined from calcium and magnesium concentrations in ground water from well 977.

Concentrations reported in milligrams per liter. All concentrations are maximum observed detect.

NA - not applicable.

NAB - detected at concentrations not statistically above background.

NCA - no criteria available. 
Only cadmium, manganese, sulfate, and uranium are evaluated for the Deweesville/Conquista ground water. The UCL ground water concentrations for cadmium and manganese in each of the contamination zones (east, north, south, and west) exceed the aquatic life values, indicating that using water from any contamination zone as the sole source of water for a pond would threaten aquatic organisms. The UCL concentrations for uranium in each contamination zone are below the comparison value. No comparison water quality values are available for sulfate.

A comparison of the concentrations of cadmium, manganese, sulfate, and uranium detected in the Deweesville/Conquista ground water with the three sources of reference ground water (well 951, wells southeast of FM 791, and the Hobson area) indicates that the concentrations for the four selected constituents are lower in the reference water than in the Deweesville/Conquista, with the exception of uranium (Table 7.2). The uranium concentration in the Hobson area $(11 \mathrm{mg} / \mathrm{L})$ is higher than the concentrations detected in the north and south contamination zones.

Reference ground waters also were compared to the available water quality values for the protection of aquatic life, livestock, and irrigated plants. The aquatic life value for cadmium was exceeded by the concentration detected in the wells southeast of FM 791 (Table 7.2). Manganese and uranium concentrations did not exceed the comparison values, and no aquatic life values are available for sulfate (Table 7.2). The sulfate concentration in the wells southeast of FM 791 exceeds the livestock watering value, the cadmium concentrations were all below the comparison value, and no comparison values are available for manganese and uranium (Table 7.2). In terms of the water concentrations protective of irrigated plants, the manganese concentrations in all three sources of reference ground water exceed the comparison value. For cadmium, the only other contaminant of potential concern with an irrigation water value, the concentrations detected in two of the reference waters exceeded or equaled the irrigation water value (Table 7.2).

In the Dilworth aquifer, 10 constituents were selected as contaminants of potential concern in the assessment of risk to environmental receptors. These contaminants were selected from ground water data from two potential exposure points (eastern and western contamination zones). The ground water concentrations presented in Table 7.3 are maximum detects. For the five ground water contaminants detected above background in the eastern contamination zone, aluminum, nickel, and zinc concentrations are below the aquatic life water quality values, cadmium level exceeds the value, and cobalt has no comparison value. The nickel, uranium, and zinc concentrations in the western contamination zone are below the respective comparison values, the iron concentration exceeds the value, and the aluminum concentration slightly exceeds its comparison value. Ammonium and cobalt were detected in the western contamination zone above background, but there are no comparison values to evaluate whether these concentrations could represent a hazard to aquatic life. 
Another potential use of the ground water in the area is agricultural irrigation. Tables 7.2 and 7.3 compare the approximate concentrations in irrigation water that should be protective of plants (EPA, 1972) with ground water concentrations in the Deweesville/Conquista and Dilworth, respectively. These irrigation water values were developed for agricultural practices and are protective of crops from the toxic effects associated with buildup of inorganics in the soil under continuous irrigation conditions.

Comparison values for protection of irrigated crops are available for cadmium and manganese in the Deweesville/Conquista aquifer (Table 7.2). The detected concentrations of cadmium and manganese in each of the four contamination zones exceed their respective comparison values. This suggests that using ground water from any of these regions as a source of continuous irrigation water is unacceptable.

A comparison of the observed concentrations in Dilworth ground water with the available irrigation water values suggests that water from the eastern contamination zone would not be suitable due to elevated concentrations of cadmium and cobalt, which exceed the comparison values. The concentrations of cobalt and iron in the western contamination zone exceed comparison values, indicating this water would not be suitable for continuous use as irrigation water.

The total soluble salt content is another basic criterion for the suitability of water quality for irrigation. Excess salts in water increases the osmotic pressure of the soil solution. This increase can elicit a physiological drought condition in the plants. The total soluble salt content of water can be measured by the specific conductance. The upper end of the acceptable range for specific conductance in most agricultural plants is $\mathbf{3 0 0 0}$ micromho per centimeter $(\mu \mathrm{mhos} / \mathrm{cm})$ (Follett and Soltanpour, 1985). The specific conductance measured in representative wells from each of the four contamination zones in the Deweesville/Conquista were all above $3000 \mu \mathrm{mhos} / \mathrm{cm}$ and ranged from 12,170 to $19,100 \mu \mathrm{mhos} / \mathrm{cm}$. Water from the Dilworth also would not be acceptable based on the specific conductance results, which ranged from 3890 to 5000 $\mu \mathrm{mhos} / \mathrm{cm}$.

The $\mathrm{pH}$ levels of ground water collected from several monitor wells in the Deweesville/Conquista near the site generally range from 3 to 5 . The $\mathrm{pH}$ of the Dilworth at monitor well 977 (eastern portion of the contaminated zone) ranges from 4 to 5. The acid death point for warmwater fish is reported to be at a $\mathrm{pH}$ of approximately 4 (Swingle, 1969). At pH levels ranging from approximately 4 to 5, reproductive impairment in fish has been reported (Swingle, 1969).

Therefore, contaminated ground water from both the Deweesville/Conquista and Dilworth would not be suitable for fish to live in if a pond were created.

\subsubsection{Aquatic risk}

Surface water and sediment samples have been collected at the site and immediate vicinity. The amount of data is limited in that only one round of 
sampling has been conducted at most of the locations and the sampling dates are not uniform. The samples were collected prior to the stabilization of on-site tailings. It is not known whether these data are representative of current conditions at the site.

\section{Surface water in Tordilla Creek and Scared Dog Creek}

Surface water samples were collected from seven locations in Tordilla Creek (location IDs 522, 691, 523, 524, 513, 514, and 225) and from one location in Scared Dog Creek (Location ID 226) (Figure 7.1). The results are presented in Table 7.4. These data are from filtered samples with the exception of locations 225 and 226, which are unfiltered results.

No apparent trends in the Tordilla Creek data indicate decreasing concentrations with increasing distance downstream from the site. A comparison of the filtered data with available aquatic life values indicates that none of the concentrations exceed the values. However, comparison values are not available for molybdenum, sulfate, and vanadium. Although it is not possible without additional information to evaluate whether the detected concentrations for these constituents could result in adverse effects, it is unlikely that a diverse assemblage of aquatic organisms occur throughout the creek due to its ephemeral nature. Based on the available data and water quality values, it does not appear that the water quality in Tordilla Creek has been adversely affected.

The most recent data collected (January 1993) are unfiltered results from the location in Scared Dog Creek and one location in Tordilla Creek. For four of the constituents detected (aluminum, chromium, iron, and vanadium) the concentrations in Scared Dog Creek were more than 1 order of magnitude above those detected in Tordilla Creek. The concentrations of arsenic, molybdenum, and uranium in Tordilla Creek were slightly higher than in Scared Dog Creek. The TWC aquatic life criteria are for dissolved (filtered) metals in water. The criterion for iron, which is a Federal Water Quality Criteria (FWOC), is for unfiltered iron concentrations. The iron concentration detected in Tordilla Creek $(0.75 \mathrm{mg} / \mathrm{L})$ was below the criterion of $1.0 \mathrm{mg} / \mathrm{L}$, while the concentration in Scared Dog Creek (32.6 mg/L) was well above this criterion.

In summary, it is difficult to draw conclusions from the available surface water data other than that the concentrations for several constituents in Scared Dog Creek were elevated with respect to Tordilla Creek.

\section{Surface water in ponds}

Surface water was collected from five ponds in the site vicinity (Figure 7.1). Although no field surveys of the aquatic organisms potentially occurring in these ponds have been conducted, some ponds in the site vicinity, such as the pond east of the former pile 3 , is known to contain channel catfish. However, there is no information on the occurrence of other aquatic life in these ponds. The sampling results are presented in Table 7.5. With the exception of one 1993 


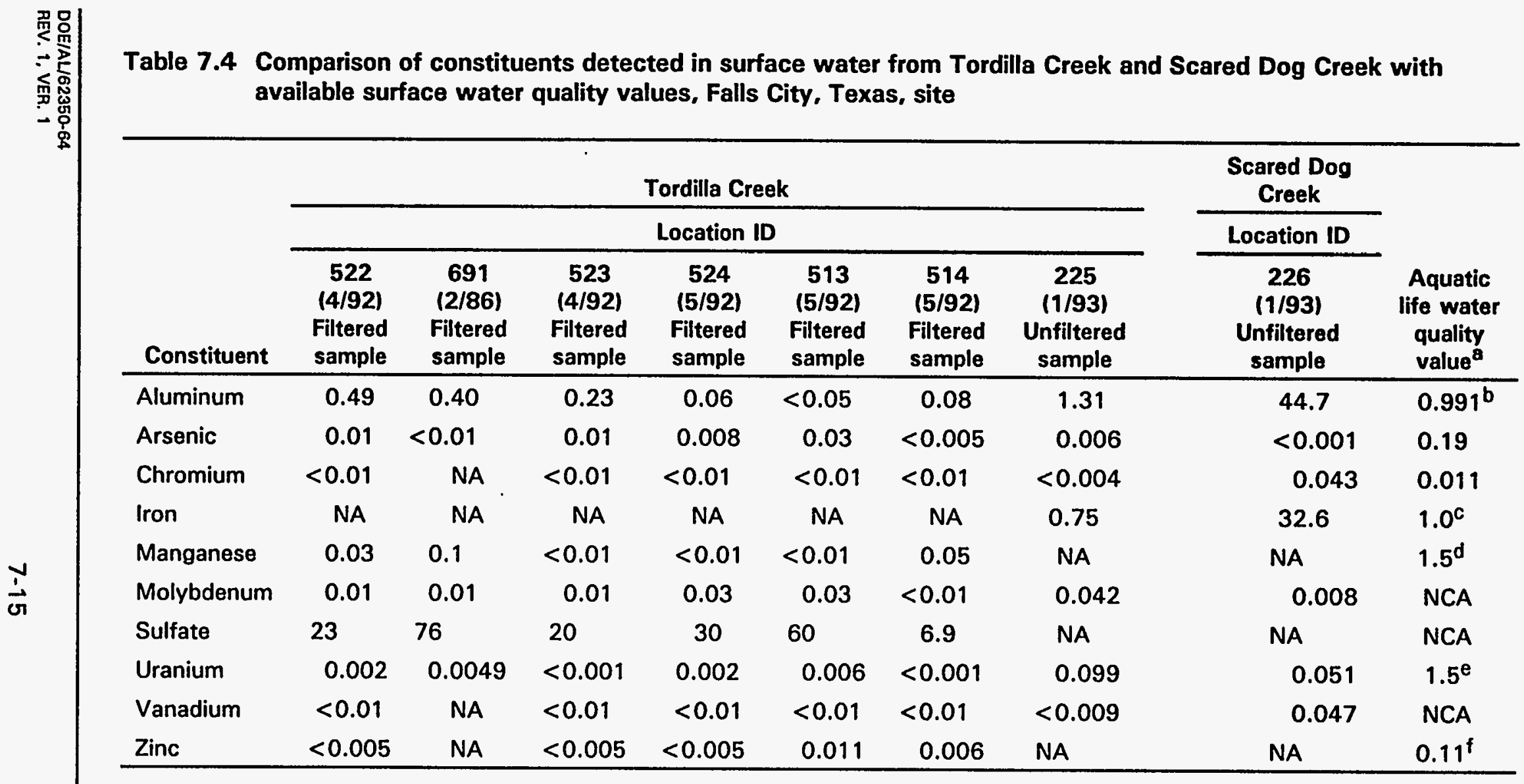

${ }^{8}$ Values presented are Texas water quality criteria for chronic protection of freshwater aquatic life (TWC, Section 307.6), unless specified otherwise. The TWC criteria are for dissolved (filtered) metals in water.

${ }^{b}$ TWC criterion for acute exposure; no chronic value available.

'No TWC criterion available; value presented is the chronic FWOC (EPA, 1986).

${ }^{d}$ No TWC criterion available; value presented is the lower end of the tolerance range for freshwater aquatic life (EPA, 1986).

${ }^{\circ} \mathrm{No}$ TWC or federal criterion available; value presented is the water hardness-related standard for the chronic protection of aquatic organisms in the state of Colorado (CDH, 1991). The standard presented was calculated using the uranium-specific equation and an assumed hardness of $100 \mathrm{mg} / \mathrm{CaCO}_{3}$.

fWater hardness-dependent TWC criterion (TWC, Section 307.6); criterion presented was calculated using a constituent-specific equation and an assumed water hardness of $100 \mathrm{mg} / \mathrm{L} \mathrm{CaCO}_{3}$.

All concentrations reported in milligrams per liter; dates of sample collection are shown in parentheses.

NA - not analyzed.

NCA - no criteria available. 


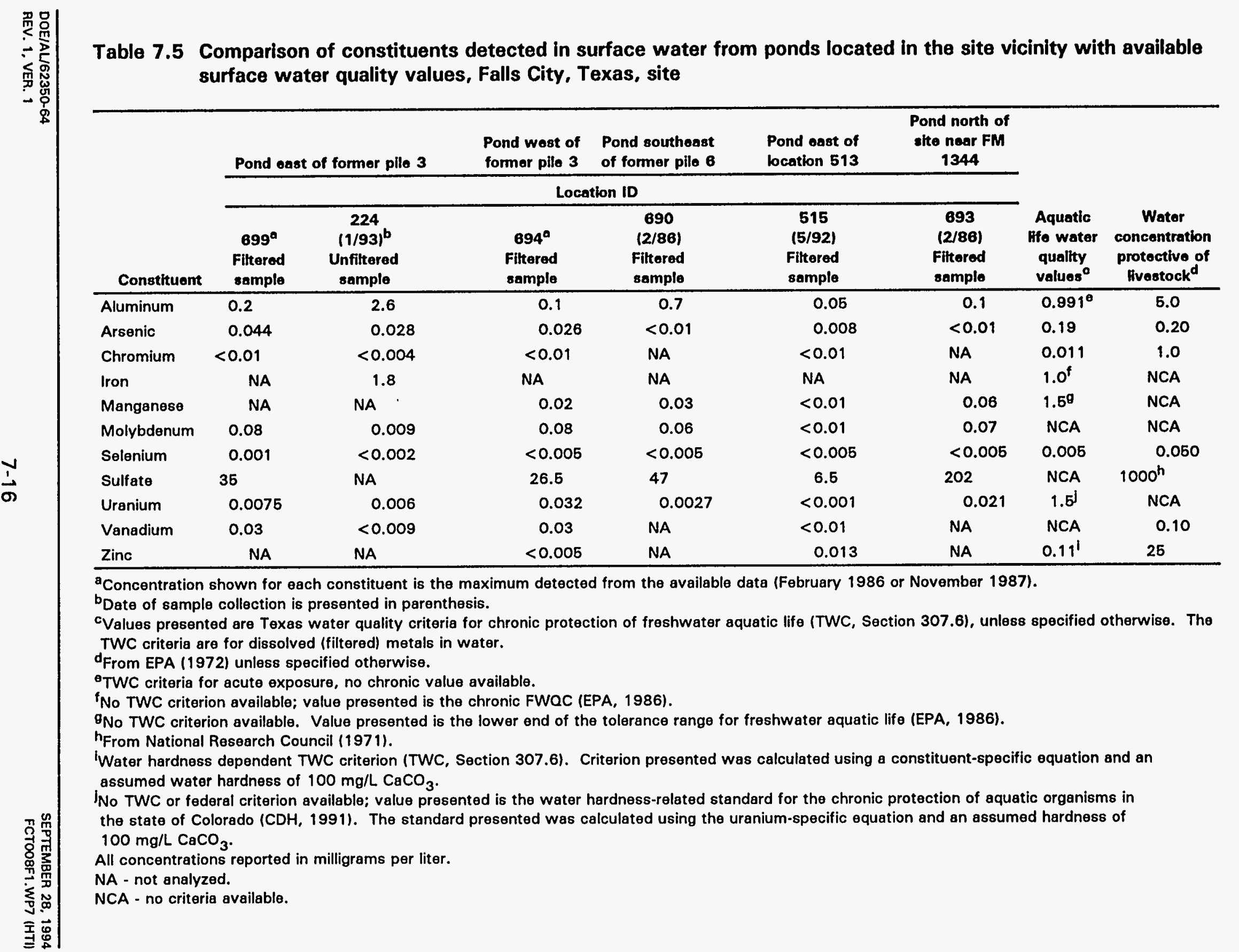


sample collected from the pond east of the former pile 3, the data are from filtered samples.

A review of the filtered data indicates that the highest concentrations of aluminum and arsenic were detected in the pond east of the former pile 3 . The highest concentrations of manganese and sulfate were detected in the pond southeast of the former pile 6 . Selenium was detected only in the pond east of the former pile 3 , at a concentration of $0.001 \mathrm{mg} / \mathrm{L}$, but the detection limits for the other locations were higher than this value ranging from 0.002 to 0.005 $\mathrm{mg} / \mathrm{L}$. Uranium was highest $(0.032 \mathrm{mg} / \mathrm{L})$ in the pond west of the former pile 3 . The highest concentrations of molybdenum $(0.08 \mathrm{mg} / \mathrm{L})$ and vanadium $(0.03$ $\mathrm{mg} / \mathrm{L}$ ) were detected in both the pond west of the former pile 3 and the pond east of the former pile 3.

The aquatic life water quality values for aluminum and iron were exceeded in the pond east of the former pile 3 (Table 7.5). However, the aluminum concentration in this pond $(2.6 \mathrm{mg} / \mathrm{L})$ is from an unfiltered sample and the criteria are based on dissolved aluminum. Therefore, the concentration of dissolved aluminum in the pond may be lower than the comparison value. The iron concentration could adversely affect aquatic organisms if chronic exposure to iron occurred. Because several of the detected constituents have no aquatic life values, it is not possible to evaluate whether they represent an ecological hazard. Based on available information and comparison values, little evidence suggests the water quality in these ponds is adversely affected. The lack of site-specific background surface water quality data prevents drawing a definitive conclusion concerning conditions in these ponds.

\section{Sediments}

Three sediment samples were collected in January 1993 (one sample each from the pond east of the former pile 3, Tordilla Creek, and Scared Dog Creek).

No state or federal sediment quality criteria (SOC) are established for the protection of aquatic life for the constituents detected at the site.

The EPA is evaluating a methodology based on the three-phase sorption model for free-metal ion activity and is assessing its applicability for determining the bioavailable fraction within sediments (EPA, 1989b). Other predictive models and methods are also being investigated for metals, but one approach has not been accepted to adequately develop sediment-based metals criteria (Shea, 1988; Chapman, 1989; EPA, 1989b; NOAA, 1990; Di Toro et al., 1991; Burton, 1991). Therefore, only a qualitative hazard assessment of the metals detected in sediments is presented in this risk assessment.

National Oceanic and Atmospheric Administration (NOAA) effects-based sediment quality values are available for evaluating the potential for constituents in sediment to cause adverse biological effects. These values are not standards or criteria. Effects range-low (ER-L) values are concentrations equivalent to the 
lower 10 percentile of available data screened by NOAA and indicate the low end of the concentration range in specific sediments at which adverse biological effects were observed or predicted in sensitive species and/or life stages. The effects range-median (ER-M) values are concentrations based on the NOAA screened data at which effects were observed or predicted in 50 percent of the test organisms evaluated. The NOAA ER-L and ER-M values were compared with the concentrations of the constituents detected in sediment. One limitation of the ER-L and ER-M is that the concentration at which toxicity was observed could not be readily extrapolated from one sediment location to another. Sediment characteristics (e.g., organic carbon content, grain/particle size) greatly influence the contaminant toxicity; thus, the ER-L and ER-M cannot be used as a direct indicator of adverse effects to aquatic organisms.

NOAA sediment quality values are available for three of the detected constituents (i.e., antimony, arsenic, and chromium) (Table 7.6). None of the detected concentrations for these three metals exceed their respective NOAA ER- $L$ values (Table 7.6). This suggests the potential threat of these metals to aquatic life is low. Because there are no SOCs for aluminum, molybdenum, selenium, uranium, and vanadium, it is not possible with available information to evaluate whether the detected sediment concentrations could adversely affect biota.

\section{Fish tissue}

Five channel catfish were collected from the pond east of the former pile 3 in January 1993. Before analysis, the fish were divided into edible (muscle tissue) and inedible (bone, skin, and organ) portions. The edible portions of all the fish and the inedible portions of the three largest fish were analyzed for the following inorganics: aluminum, antimony, arsenic, cadmium, chromium, molybdenum, selenium, uranium, and vanadium. The maximum detected concentrations for the edible and inedible samples are presented in Table 7.7. In addition to the inorganics, the samples were analyzed for lead-210, polonium210, radium-226, and thorium-230. However, these radionuclides are not included in Table 7.7 because the results were below the detection limits. Arsenic and cadmium were not detected in edible tissue, but were detected in the inedible portions. The other constituents which were detected (aluminum, chromium, and selenium) were found in both the edible and inedible portions.

Little information is available concerning the relationships between tissue contaminant residue levels and their biological effects on aquatic organisms. Data available in the literature on total concentrations in bone, skin, and organs combined is insufficient, results usually are reported for separate organs (e.g., liver, kidney) or bones only. Therefore, natural background concentrations reported from whole-fish (edible plus inedible) analyses are compared in Table 7.7 with concentrations reported in edible tissue. A comparison of the maximum detected concentrations in edible tissue with the available background concentrations shows that all the constituents are within the background range, although no background data were found for aluminum. The maximum 


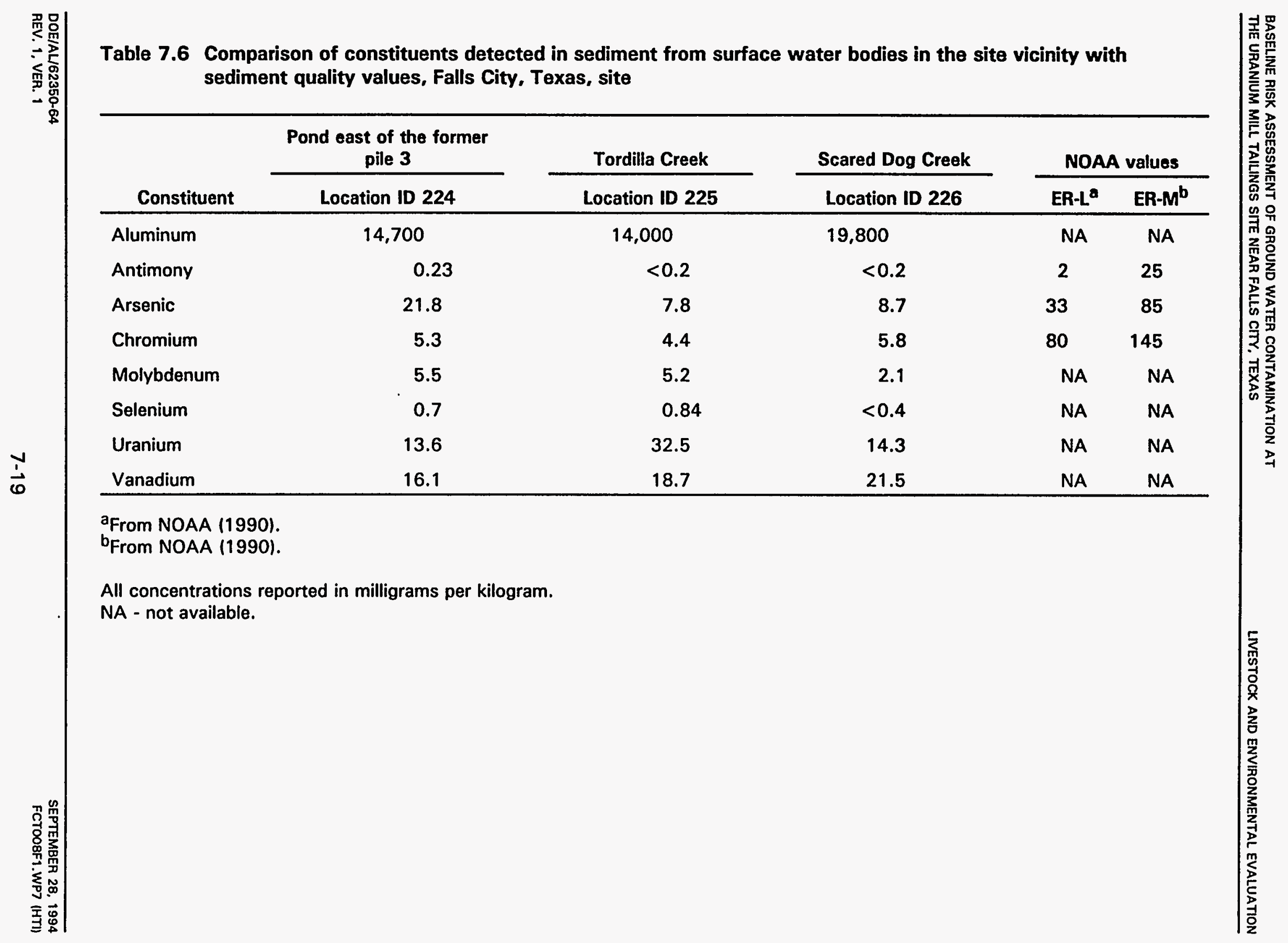




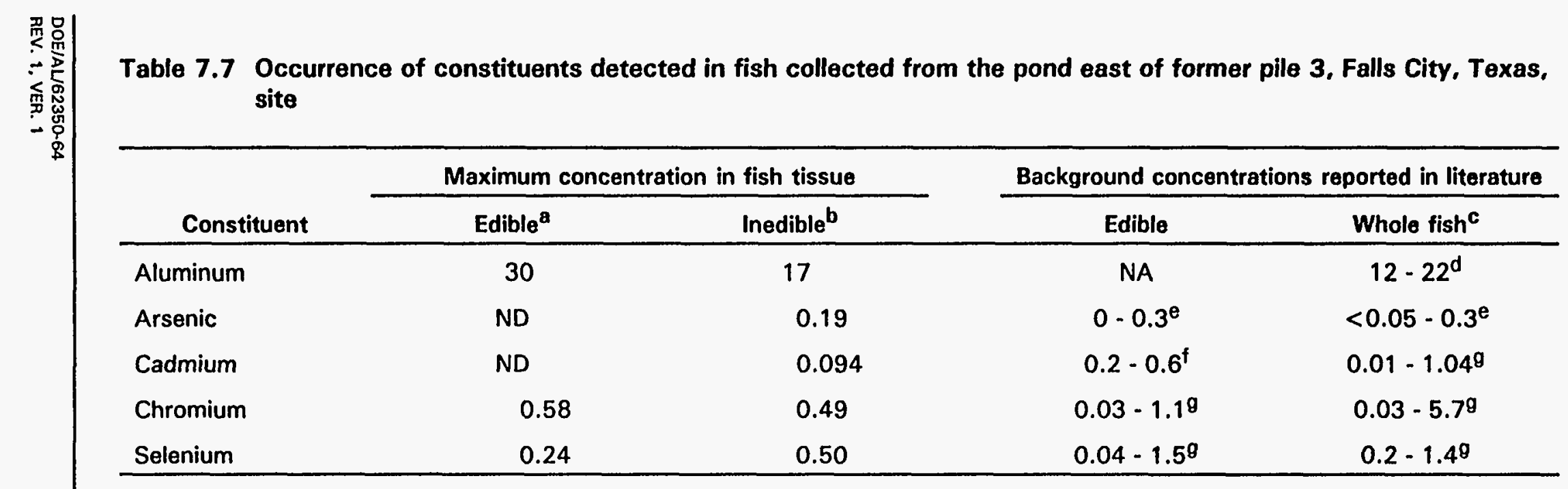

a Muscle tissue.

bones, skin, and organs.

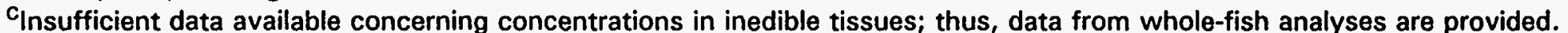

${ }^{d}$ Data collected from a control site used in a river basin study in west-central Colorado.

Eackground concentration range reported in channel catfish (Eisler, 1988).

fData collected from western Montana (Eisler, 1985b).

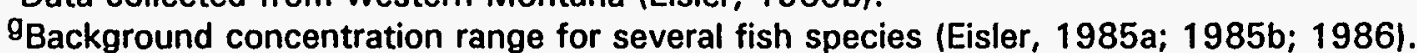

All concentrations reported in milligrams per kilogram fresh weight. The fish tissue results were converted from dry weight to fresh weight using the percent moisture of each sample.

NA - no data found in available literature.

ND - not detected. 
concentrations of each constituent detected in the inedible portions were within their respective background range in whole fish. Although the concentrations in the inedible portion cannot be directly compared to whole-body concentrations, the concentrations may not be elevated.

Based on the available site-specific data and scientific literature, there is no evidence that bioaccumulation is a concern or that the detected concentrations would cause adverse effects to the fish. However, analysis of whole-body samples from the site and from a site-specific background location would provide useful data for evaluating conditions at the site.

\subsection{POTENTIAL IMPACTS TO LIVESTOCK}

Livestock are known to have access to the pond east of the former pile 3 and the pond west of the former pile 3 for drinking water. Although it has not been observed, livestock could drink water from the other ponds. Because of the intermittent nature of Tordilla Creek and Scared Dog Creek, it is unlikely that water, when present, would constitute a significant source of water for livestock.

Current and future hypothetical use of ground water from the two aquifers as a source of drinking water for livestock was evaluated. Currently, no wells which access the Deweesville/Conquista are used as a source of water for livestock. However, domestic wells located near the site may access the Dilworth for this purpose.

Ingestion by livestock of vegetation which may have bioconcentrated contaminants from shallow ground water is a potential pathway. Results from plant analyses suggest that most of the concentrations detected in plants from the site vicinity are above background concentrations reported in the literature. However, the concentrations in the plants which were analyzed (aquatic and semiaquatic) may not be indicative of concentrations in plants such as grasses that would comprise the bulk of livestock forage.

To evaluate the potential impact to livestock that might drink out of the ponds in the site vicinity, the detected concentrations were compared to approximate drinking-water concentrations considered to be protective of livestock (Table 7.5).

Livestock drinking water values are not available for iron, manganese, molybdenum, and uranium (Table 7.5). None of the constituents detected in the pond east of former pile 3 , the pond west of former pile 3 , the pond southeast of former pile 6 , the pond east of Location 513 , and the pond north of the site near FM 1344 exceed the available livestock values. It should be noted that cases of molybdenum poisoning in livestock have been reported in the area in the past. At low levels, molybdenum is an essential nutrient for animals.

Several factors influence the toxicity of molybdenum at higher levels, including its chemical form, the copper status and dietary intake of the animal, the form 
and amount of sulfur in the diet, and other less well defined factors (EPA, 1972).

Based on past and current agricultural activities in the area surrounding the site, the possibility exists that, in the future, ground water from either aquifer could be used to fill a livestock watering pond. In an attempt to evaluate the potential impact to livestock in this scenario, the approximate drinking water concentrations considered to be protective of livestock (EPA, 1972) were compared to ground water concentrations for several constituents in the Deweesville/Conquista (Table 7.2) and for the contaminants of potential concern in the Dilworth (Table 7.3).

For the Deweesville/Conquista aquifer, this comparison shows that the sulfate concentrations in all four of the contamination zones (north, south, east, west) exceed the livestock value (Table 7.2). If this ground water were used as the sole source of drinking water for livestock, it could result in sulfate-induced diarrhea in the exposed animals (Church, 1984). Cadmium concentrations in the east, north, and south plume regions exceed the comparison value, while the concentration in the west plume is below the value. No comparison water quality values have been reported for manganese and uranium. Nevertheless, the available information suggests that using Deweesville/Conquista ground water as a sole source of drinking water for livestock may be unacceptable due to sulfate and cadmium concentrations that are at levels unsuitable for livestock watering.

Two discrete areas have been identified in the Dilworth aquifer based on ground water quality: the eastern and western contamination zones. A comparison of the maximum concentrations for the contaminants of potential concern in these areas with livestock values (Table 7.3 ) shows that none of the concentrations in the eastern or western contamination zones exceed the available values. However, no comparison value is available for uranium.

\subsection{LIMITATIONS OF THE ECOLOGICAL RISK ASSESSMENT}

The qualitative evaluation of potential ecological risks presented here is a screening level assessment of the risks associated with potential exposure of plants and animals to contaminated ground water, surface water, and sediment at the Falls City site. Sources of uncertainty in any ecological assessment arise from the monitoring data, exposure assessments, toxicological information, and the inherent complexities of the ecosystem. In addition, methods of predicting nonchemical stresses (e.g., drought), biotic interactions, behavior patterns, biological variability (i.e., differences in physical conditions, nutrient availability), and resiliency and recovery capacities are often unavailable. In general, limitations for the Falls City ecological risk assessment include the following:

- Only a small amount of ecological data were collected during this screening.

- No site-specific background data are available. 
- Only limited ecotoxicological reference data are available.

- Considerable uncertainty is associated with the toxicity of mixtures of contaminants.

\subsection{SUMMARY}

A limited data set currently exists of the water and sediment quality in the surface water bodies in the site vicinity. No trends, such as a decrease in concentrations with increasing distance downstream from the site, were apparent in the surface water quality data for Tordilla Creek. None of the aquatic life water quality values were exceeded in Tordilla Creek. Although several of the detected constituents have no comparison values, little evidence indicates water quality is affected. The concentration of iron in Scared Dog Creek exceeded the water quality criterion and could represent a hazard to aquatic organisms if chronic exposure occurred. Due to the intermittent nature of Scared Dog and Tordilla Creeks, there may be no aquatic receptors. However, no field surveys have been conducted to inventory potential aquatic organisms in the site vicinity.

The concentrations of several constituents detected in water from Scared Dog Creek were elevated with respect to Tordilla Creek. However, it is difficult to evaluate the reasons for this finding without site-specific background data.

Surface water quality of the ponds in the site vicinity was evaluated. With the exception of iron detected in the pond east of former pile 3, none of the constituents were detected above the aquatic life water quality values. Aluminum was detected in an unfiltered sample at a concentration above the criterion; however, the concentration of filtered aluminum, on which the criterion is based, is unknown and may not be above the criterion.

The concentrations of antimony, arsenic, and chromium detected in sediment from the pond east of the former pile 3, Tordilla Creek, and Scared Dog Creek were below the sediment quality values, suggesting these constituents are not hazardous to aquatic organisms. Because sediment quality values are not available for the other constituents, it is not possible with available information to evaluate the potential ecological threat of these concentrations.

Livestock may drink water at several current exposure points. Livestock are known to drink from the pond east of the former pile 3, the pond west of the former pile 3. The potential also exists that livestock could drink water from the other ponds in the site vicinity (e.g., the pond southeast of the former pile 6).

Concentrations detected in each of the ponds were compared with drinking water concentrations considered protective of livestock. Although livestock drinking water values are not available for some of the constituents, none of the available values were exceeded in any of the ponds. This suggests that water from this pond would be a suitable source of drinking water for livestock. 
It is possible that in the future ground water from the Deweesville/Conquista aquifer could be used for watering livestock. An evaluation of conditions in the Deweesville/Conquista indicates that ground water from each of the four plume regions would not be suitable for livestock due to elevated sulfate concentrations. The concentrations of cadmium in the east, north, and south contamination zones exceeded the livestock drinking water value as well. Other constituents could not be evaluated because no livestock drinking water guidelines are available.

Based on available data and guidelines, ground water from the eastern and western contamination zones of the Dilworth should be suitable for livestock drinking water.

Using ground water from the Deweesville/Conquista to continuously irrigate crops would be unacceptable because of cadmium and manganese concentrations and because of the total soluble salt content. Water from the western and eastern contamination zones in the Dilworth should be acceptable for crop irrigation.

Cadmium and manganese concentrations also preclude using ground water from the DeweesvillelConquista and the eastern contamination zone of the Dilworth as a habitat for fish. Aluminum in the western contamination zone of the Dilworth slightly exceeded the aquatic life value, indicating this water may be unacceptable for aquatic organisms.

Available data suggest a low potential hazard to the food chain from the constituents detected in media at the site (via bioaccumulation and biomagnification). Fish tissue data indicate the concentrations are within the background concentration range reported in the literature. Concentrations for most of the constituents detected in plant samples from the site were above the background concentrations reported in the literature. However, no site-specific background data are available to compare with data from the site and from the literature.

Sufficient water quality and sediment quality values were not available to allow comprehensive evaluation of the impact of surface water and sediments on ecological receptors and of contaminated ground water on ecological receptors. 


\subsection{INTERPRETATION AND RECOMMENDATIONS}

\subsection{RISK SUMMARY}

The UMTRCA requires the UMTRA Project to protect public health and the environment from radiological and nonradiological hazards associated with the uranium mill sites. This baseline risk assessment was conducted on the Falls City site to evaluate the presence of these hazards. Because the Deweesville/Conquista ground water is currently not used by area residents, human health is not at risk from direct ground water use. The same is true for the eastern and western zones in the Dilworth aquifer.

Ground water from the Deweesville/Conquista is variable in occurrence and quality near the site. The health risk increment that would be associated with potential future use of ground water contaminated by the milling activities in the Deweesville/Conquista cannot be quantitatively determined at present. However, sulfate, manganese, and uranium are elevated as a result of the milling activities at the site and are present at levels high enough to cause serious adverse health effects following very short exposures. Because of the high concentrations of sulfate, manganese, and uranium, the ground water is not suitable for use as drinking water. This water would not be recommended as a source of water for fish to live in, if a pond were created, or as a source of continuous irrigation water for agricultural crops. Due to sulfate and cadmium levels, the contaminated ground water would not be suitable as a sole source of drinking water for livestock.

Assuming the Dilworth contaminated zone is defined, human health would not be adversely affected by ingesting beef and milk from cattle that had consumed Dilworth ground water. Based on current concentrations, use of this ground water as drinking water would result in adverse health effects in potentially exposed humans due to sulfate and iron levels. The estimated iron exposure level may be associated with elevated levels of iron in the body that could lead to increased skin pigmentation and possibly cirrhosis of the liver. If the Dilworth ground water were used as drinking water for infants, sulfate levels could result in severe persistent diarrhea, potentially leading to dehydration. These levels of sulfate could also induce diarrhea in adults drinking the water.

In the western contamination zone of the Dilworth aquifer, the lifetime excess cancer risk associated with ingestion of uranium contaminated ground water is at a level of 1 in 1000 . However, any excess lifetime cancer risks associated with uranium in ground water in the eastern contamination zone are within the acceptable range as defined by the National Contingency Plan (NCP) of 1 in 10,000 and 1 in $1,000,000$.

Excess lifetime cancer risks associated with indirect human exposure to uranium and radionuclides other than uranium due to the use of the Dilworth contaminated ground water from any contamination zone for livestock watering 
appear to be less than 1 in $1,000,000$, although this is only an order of magnitude estimate.

The contaminated ground water in the Dilworth aquifer would likely be acceptable as a source of irrigation water and drinking water for livestock. However, if a pond were created and filled with the contaminated ground water, the cadmium levels and acidity in the eastern portion of the contamination zone, and possibly aluminum in the western region, would not be suitable for fish to live in.

Livestock are known to drink surface water from several of the ponds in the site vicinity. A comparison of the detected constituent concentrations with livestock drinking water guidelines indicates that none of the observed concentrations exceed the available guidelines. This suggests that water from these ponds is likely acceptable for livestock to drink.

The available surface water and sediment data from the surface water bodies (creeks and ponds) in the site vicinity were evaluated with respect to risks to potential aquatic receptors. However, it should be noted that the two creeks in the site vicinity (Tordilla and Scared Dog Creeks) are ephemeral and likely do not have diverse aquatic wildlife due to the scarcity of water. None of the constituent concentrations detected in the surface water and sediments exceeded the available water quality criteria and guidelines or sediment values, with the exception of the elevated iron observed in surface water from Scared Dog Creek. The iron concentration observed in the pond east of former pile 3 was only slightly above the water quality guideline and should not represent a hazard to most aquatic life.

The available fish tissue and plant tissue data collected near the site suggest the potential for the constituents detected in these media to represent a food-chain hazard is considered low. However, this evaluation is complicated by the fact that no background data are available for comparison. Thus, no definitive conclusion regarding food-chain hazards can be drawn at this time.

\subsection{LIMITATIONS OF THIS RISK ASSESSMENT}

The following limitations to this evaluation of health risks should be noted:

- This document evaluates risks associated with exposures only to inorganic contaminants of ground water at the UMTRA site near Falls City.

- In general, the results presented in this document are based on filtered $(0.45 \mu \mathrm{m})$ water samples. The effect of filtration differs for different elements. Filtered samples can have somewhat lower or equal concentrations than unfiltered samples for some constituents. Constituents in suspension may be lost with filtration, but can still produce toxic effects if ingested and broken down in the acidic environment of the stomach. 
- Contaminant toxicities vary from person to person. Presenting exposure ranges that can produce toxic effects emphasizes these variabilities. However, it is not possible to account for all sources of variability and still present useful and meaningful analyses. Specific subpopulations known to be more sensitive to toxic effects of given constituents have been noted.

- Standardized reference values from agencies such as the EPA and literature values are used to determine tissue concentrations in livestock and toxic effects in humans. These reference values themselves are limited because first, toxicity, uptake, and bioconcentration data are not available for all constituents elevated above background at the site. Second, data obtained from laboratory animal testing at exposure doses different from those expected at the site were used to determine toxicity. The relationship between dose and response is not always linear, and humans do not always exhibit the same responses as animals. Third, data used to determine toxicity generally are based on exposure to only the constituent of concern. In reality, exposures generally occur simultaneously to multiple chemicals. The interactive effects of multiple constituents and the impact of these interactions on expected toxicity generally cannot be accurately assessed from existing data.

- Although considerable effort was directed at determining contamination zone movement and placing monitor wells in locations that capture maximal contamination, the wells may not be located in the areas of highest contaminant concentration due to the variability in physical systems.

- Variability can be introduced through sampling and analytical processes. However, the data at UMTRA Project sites have been collected over many years and subjected to rigorous quality assurance procedures. The use of multiple samples increases the reliability and validity of the collected data.

- The drinking water pathway is considered the major determinant of exposure in this assessment. However, the incremental contribution from the ground water-irrigated produce ingestion pathway, which could not be estimated here, could be significant. In addition, many factors in the beef and milk ingestion pathway have considerable uncertainties that could affect the estimates by an order of magnitude.

The limitations for the Falls City ecological risk assessment include the limited amount of ecological data collected during this screening, little knowledge about site-specific intake rates for wildlife or amounts of contaminants taken up by plants, limited ecotoxicological reference data available, and considerable uncertainty associated with the toxicity of mixtures of contaminants.

By presenting ranges of toxic effects, summaries of available data on health effects and interactions, and outlines of potential limitations, this document provides a reasonable interpretation of potential health risks associated with ground water contamination at this site. This assessment presents both 
contamination and risk as accurately as possible, based on available data, and conveys areas of uncertainty.

\subsection{GROUND WATER CRITERIA}

In 1983, the EPA established health and environmental protection standards for the UMTRA Project, and in 1987, the EPA proposed revised ground water standards. The UMTRA Project is required to adhere to the 1987 proposed ground water standards until final standards are published. The proposed ground water standards consist of ground water protection standards to evaluate disposal cell performance and ground water cleanup standards for existing contamination at processing sites. These standards are summarized in Table 8.1 for constituents that have proposed MCLs. Because an MCL is not established for every contaminant, the proposed standard requires meeting background levels for those contaminants that do not have an MCL.

While these ground water protection and cleanup standards apply specifically to the UMTRA Project, the EPA has also published drinking water health advisory levels for both long- and short-term exposures (Table 8.1).

The following contaminant concentrations in the Dilworth aquifer plume wells have exceeded the EPA-proposed MCL and/or the EPA health advisory levels: antimony, boron, cadmium, nickel, selenium, vanadium, and uranium. In addition, arsenic, boron, molybdenum, strontium, thallium, and uranium concentrations in the background monitor wells have exceeded the MCL and/or health advisories.

Antimony exceeded the 10-day health advisory for a 10-kg child and the lifetime health advisory for a $70-\mathrm{kg}$ adult. Boron, selenium, and vanadium exceeded the health advisories in the plume; however, the concentrations of these constituents are not statistically above background.

\subsection{RISK MITIGATION MEASURES}

Historically, there has been little or no use of the upper, contaminated aquifer near the Falls City site because of its naturally poor quality and because good quality water is available from deeper aquifers. However, because significant risks are associated with using contaminated ground water from the Deweesville/Conquista aquifer, the potential ways to restrict inadvertent use of contaminated ground water are described below.

Institutional controls are described in the proposed UMTRA ground water standards as mechanisms that can be effectively used to protect human health and the environment by controlling access to contaminated ground water (52 FR 36000). Although the proposed standards refer to institutional controls for long periods of time (e.g., up to 100 years during natural flushing), this concept can also be applied to short-term or interim restriction of access to ground water. Because it could take years to characterize ground water at the 
Table 8.1 Concentration limits of constituents in the Dilworth aquifer

\begin{tabular}{|c|c|c|c|}
\hline Constituent & $\begin{array}{c}\text { UMTRCA MCL } \\
\text { (mg/L) }\end{array}$ & $\begin{array}{c}\text { Health advisories } \\
\text { 10-kg, 10-day } \\
\text { (mg/L) }\end{array}$ & $\begin{array}{c}\text { Health advisories } \\
\text { 70-kg adult lifetime } \\
\text { (mg/L) }\end{array}$ \\
\hline \multicolumn{4}{|l|}{ Chemicals (inorganic) } \\
\hline Antimony & NA & 0.015 & $0.003^{a, b}$ \\
\hline Arsenic & $0.05^{a}$ & NA & NA \\
\hline Barium & 1.0 & NA & 2 \\
\hline Boron & NA & $0.9^{a, b}$ & $0.6^{\mathrm{a}, \mathrm{b}}$ \\
\hline Cadmium & $0.01^{b}$ & 0.04 & $0.005^{b}$ \\
\hline Chromium & 0.05 & 1.0 & 0.1 \\
\hline Lead & 0.05 & NA & $0.015^{c}$ \\
\hline Mercury & 0.002 & NA & 0.002 \\
\hline Molybdenum & 0.1 & 0.08 & $0.04^{a}$ \\
\hline Nickel & NA & 1.0 & $0.1^{b}$ \\
\hline Nitrate & $44^{c, d}$ & $44^{e}$ & NA \\
\hline Selenium & $0.01^{a}$ & NA & NA \\
\hline Silver & 0.05 & 0.2 & 0.1 \\
\hline Strontium & NA & 25.0 & 17 \\
\hline Thallium & NA & $0.007^{a}$ & $0.0004^{a}$ \\
\hline Vanadium & NA & 0.08 & $0.02^{a, b}$ \\
\hline Zinc & NA & 6.0 & 2 \\
\hline \multicolumn{4}{|l|}{ Radionuclides } \\
\hline Radium-226/-228 & $5 \mathrm{pCi} / \mathrm{L}$ & NA & NA \\
\hline Uranium (U-234/-238) & $\begin{array}{c}30 \mathrm{pCi} / \mathrm{L}^{\mathrm{a}, \mathrm{b}} \\
(0.044 \mathrm{mg} / \mathrm{L})\end{array}$ & $0.03 \mathrm{mg} / \mathrm{L}^{a, b, f}$ & $0.1 \mathrm{mg} / \mathrm{L}^{\mathrm{b}, f}$ \\
\hline
\end{tabular}

${ }^{a}$ Exceeded in background Dilworth wells.

bexceeded in Dilworth wells 833 and/or 977.

${ }^{C}$ Action level.

Equal $10 \mathrm{mg} / \mathrm{L}$ nitrate as nitrogen.

eUnder review.

'Proposed value under review; expected revision: 1995.

NA - not available. 
Falls City site, and because not all 24 UMTRA sites can be evaluated simultaneously, interim institutional controls are needed before remedial action decisions are made for individual sites.

Although the presence of good quality ground water from deeper aquifers largely reduces the likelihood of ground water being used from contaminated aquifers, interim institutional controls are needed to prevent inadvertent use of contaminated water, since short-term exposures could be hazardous.

Ground water at the Falls City site is "percolating" ground water that is owned by the owner of the overlying land. Percolating water is distinct from "subterranean streams" or "underflow of a river," which are regulated differently. A permit to appropriate the ground water is not required to drill wells and pump the water. Additionally, because the Falls City site area is not located within an underground water conservation district, the Texas Water Commission does not require a water rights permit to pump water.

However, the property owner and the licensed well driller are required to submit a report after drilling a well. The report is sent to the Texas Water Well Driller's Board and describes the strata and well conditions, and includes other well log information. This report is the joint responsibility of the owner and the driller. Licensed drillers in the state should be aware of this requirement.

The law (TWC, Section 11.023) states that state ground water may be appropriated, stored, or diverted for beneficial uses.

Under Texas water law, a landowner can lawfully use all percolating ground water that can be captured from wells on the land for any beneficial purpose on or off the land. Texas has adopted the rule for absolute ownership in underground water, with certain caveats. There may be no malicious withdrawal of ground water for the sole purpose of injuring a neighbor, nor may the water be willfully wasted. A land owner may not withdraw water in a manner that results in subsidence of adjacent land.

The state of Texas does provide for Underground Water Conservation Districts (TWC, Section 52.005), although the Falls City site is not in such a district. A district may be created under authority of the Texas constitution to regulate the spacing of or production from water wells to conserve, preserve, protect, recharge, and prevent waste of ground water, and to control subsidence caused by ground water withdrawal from those wells (TWC, Section 52.021).

Surface expressions of percolating ground water (e.g., springs) are the property of the owner unless the spring has riparian value, or is the source of or adds to a stream. A land owner also has the right to sell ground water for use off the land.

The TWC has primary responsibility for implementing the state water laws. The TWC has jurisdiction over the water and water rights, including the issuance of 
water rights permits, water rights adjudication, cancellation of water rights, and enforcement of water rights (TWC, Section 5.013). The TWC also must administer the law so as to promote the judicious use and maximum conservation and protection of the quality of the environment and the natural resources of the state (TWC, Section 5.120). The TWC has the authority to make and enforce rules for conserving, protecting, preserving, and distributing underground, subterranean, and percolating water (TWC, Section 28.011). The TWC is also required to set water quality standards for the water in the state (TWC, Section 26.023).

The Texas Ground Water Protection Committee is an interagency committee that coordinates state agency actions for the protection of ground water quality in the state. The TWC is the lead agency for the committee. The committee coordinates ground water protection activities to develop and update a comprehensive ground water protection strategy for the state. The committee requires that each state agency having responsibility related to the protection of ground water maintain a public file of all documented cases of ground water contamination that are caused by activities regulated by that agency. The files are reported annually by the committee and describe the contamination and the enforcement action for each case of ground water contamination that is included in the report.

\subsection{RECOMMENDATIONS}

In general, the proposed ground water standards consisting of MCLs or background concentrations are sufficient to protect human health and the environment. However, in some cases, a risk assessment may identify site-specific factors that suggest these standards may be either too restrictive or not restrictive enough. When standards are too restrictive, such as when there is no potential for exposure, a less restrictive alternate concentration limit (ACL) may be sought. In other cases, the standards may not be sufficiently protective (for example, if many contaminants are near the MCL, with additive or synergistic adverse health effects).

At Falls City, no permanent physical barrier prevents access to contaminated ground water at the former processing site. Therefore, ACLs could not be justified for those constituents with MCLs. However, for those constituents that exceed background and do not have MCLs, this baseline risk assessment. suggests that background levels are more restrictive than necessary. This determination includes contaminants that were screened because their concentrations falling within nutritional levels (e.g., zinc). Other contaminants (e.g., cobalt or nickel) are included because they were demonstrated to be at concentrations well below adverse health effects levels. ACLs may be sought for these contaminants.

Background ground water chemistry in the Deweesville/Conquista aquifer and the geographic extent of contamination require more characterization. Existing data are not sufficient to identify mill-related potential contaminants and 
potential receptors or to precisely evaluate risks associated with the potential future beneficial uses of the Deweesville/Conquista ground water. The downgradient extent of contamination for the southern, eastern, and northern zones of contamination should be better defined by the installation of additional monitor wells. The extent of contamination in the eastern and northern contamination zones, in particular, needs further delineation.

The lithology, hydrology, and ground water chemistry of the Deweesville and the Conquista units appear to be quite distinct (BEG, 1992). These units should be treated separately in future characterization efforts. Any future monitor wells should test only one of the three Falls City units in question at a time (i.e., the Dilworth, Conquista Clay, or Deweesville Sandstone).

Additional characterization will be covered in upcoming field plans to further evaluate surface water and sediment conditions and potential ecological receptors near the site.

The potential extent of the Dilworth contamination should be verified and better defined. In addition, ground water from private wells located downgradient of the site should continue to be monitored for any impact from the site.

Because natural, localized uranium deposit areas are present in the Dilworth aquifer, the background ground water within a $2-\mathrm{mi}(3-\mathrm{km})$ radius of the site contains relatively high concentrations of toxic constituents, such as arsenic, manganese, and uranium. Sulfate, manganese, and uranium are known to be the most significant contaminants in the Deweesville/Conquista ground water. Potential human exposure to these waters would be expected to cause adverse health effects. For this reason, and because the land above some of the contamination is privately owned, access to the contaminated ground water should be controlled until the site is evaluated further. Therefore, ground water use policies should be developed involving state authorities and local land owners. 


\subsection{LIST OF CONTRIBUTORS}

The following individuals contributed to the preparation of this document.

\begin{tabular}{ll}
\hline Name & Contribution \\
\hline B. Malczewska-Toth & Overall document responsibility; authorship \\
$\begin{array}{l}\text { E. Artiglia, D. Bierley, } \\
\text { J. Gibb, R. Saar }\end{array}$ & Reviewers \\
L. Flowers & Document technical review \\
J. Blount, T. Jackson & Geochemistry \\
C. Day & Environmental evaluation \\
K. Smith & Statistics \\
E. Storms & Hydrogeology \\
M. Gawthorp-Cooper & Risk mitigation measures \\
E. Artiglia & Site manager \\
L. Keith, C. Slosberg & Word processing \\
E. Bond & Graphic design \\
J. Torline & Technical editing, document publication coordination \\
\hline
\end{tabular}




\subsection{REFERENCES}

Allison, J. D., D. S. Brown, and K. J. Novo-Gradac, 1991. MINTEQA2/PRODEFA2, A Geochemical Assessment Model for Environmental Systems: Version 3.0 User's Manual, EPA/600/3-91/021, Environmental Research Laboratory, Office of Research and Development, U.S. Environmental Protection Agency, Athens, Georgia.

Anders, R. B., 1962. "Groundwater Geology of Karnes County, Texas, in Contributions to the Hydrology of the United States," U.S. Geological Survey Water Supply Paper 1539-C.

Baes et al. (C. F. Baes III, R. D. Sharp, A. L. Sjoreen, and R. W. Shor), 1984. A Review and Analysis of Parameters for Assessing Transport of Environmentally Released Radionuclides Through Agriculture, ORNL-5786, prepared for Oak Ridge National Laboratory, Health and Safety Research Division, Oak Ridge, Tennessee.

Ballou et al. (J. E. Ballou, R. A. Gies, A. C. Case, D. L. Haggar, R. L. Buschbom, and J. L. Ryan), 1986. "Deposition and Early Disposition of Inhaled Uranium-233 Uranyl Nitrate and Uranium-232 Uranyl Nitrate in the Rat," in Health Physics, Vol. 51, pp. 755-772.

BEG (Bureau of Economic Geology, The University of Texas at Austin), 1992. "Hydrogeology and Hydrochemistry of the Falls City Uranium Mine Tailings Remedial Action Project, Karnes County Texas," prepared by C. W. Kreitler, T. J. Jackson, P. W. Dickerson, and J. G. Blount for the Texas Department of Health, Bureau of Radiation Control, under cooperative agreement No. IAC (9293)-0389, September 1992.

Berlin and Rudell (M. Berlin and B. Rudell), 1986. "Uranium," in Handbook on the Toxicology of Metals, Volume II, second edition, L. Friberg, G. F. Nordberg, and V. B. Vouk, eds., Elsevier Science Publishers, New York, New York, pp. 647658.

Buchet et al. (J. P. Buchet, R. Lauwerys, and H. Roels), 1990. "Renal Effects of Cadmium Body Burden of the General Population," in Lancet, Vol. 336, pp. 669-702.

Bunker, C. M., and J. A. MacKallor, 1973. "Geology of the Oxidized Uranium Ore Deposits of the Tordilla Hill-Deweesville Area, Karnes County, Texas; A Study of a District Before Mining," U.S. Geological Survey Professional Paper 765, Washington, D.C.

Burton, G. A., Jr., 1991. "Assessing the Toxicity of Freshwater Sediments," in Environmental Toxicology and Chemistry, No. 10, pp. 1585-1627. 
Casarett, L. J., and J. Doull, 1991. Toxicology: The Basic Science of Poisons, fourth edition, M. O. Amdur, J. Doull, and C. D. Klaassen, eds., Pergamon Press, New York, New York.

CDH (Colorado Department of Health), 1991. Basic Standards and Methodologies for Surface Water, 3.1.0., Water Quality Control Commission, Denver, Colorado.

Chapman, P. M., 1989. "Current Approaches to Developing Sediment Quality Criteria," in Environmental Toxicology and Chemistry, No. 8, pp. 598-599.

Church, D. C. 1984. Livestock Feeds and Feeding, second edition, McGraw-Hill Publishing Co., New York, New York.

Cothern, C. R., and W. L. Lappenbusch, 1983. "Occurrence of Uranium in Drinking Water in the United States," in Health Physics, No. 45, pp. 89-99.

DHHS (U.S. Department of Health and Human Services), 1993a. "Toxicological Profile for Cadmium," prepared by Life Systems, Inc., for the U.S. Department of Health and Human Services.

DHHS (U.S. Department of Health and Human Services), 1993b. "Toxicological Profile for Nickel," prepared by Clement International Corporation for the U.S. Department of Health and Human Services.

DHHS (U.S. Department of Health and Human Services), 1992a. "Toxicological Profile for Cobalt," prepared by Clement International Corporation for the U.S. Department of Health and Human Services.

DHHS (U.S. Department of Health and Human Services), 1992b. "Toxicological Profile for Manganese," prepared by Clement International Corporation for the U.S.

Department of Health and Human Services.

DHHS (U.S. Department of Health and Human Services), 1992c. "Toxicological Profile for Vanadium and Compounds," prepared by Clement international Corporation for the U.S. Department of Health and Human Services.

DHHS (U.S. Department of Health and Human Services), 1989. "Toxicological Profile for Zinc," prepared by Clement Associates for the U.S. Department of Health and Human Services.

Di Toro et al. (D. M. Di Toro, C. S. Zarba, D. J. Hansen, W. J. Berry, R. C. Swartz, C. E. Cowan, S. P. Pavlou, H. E. Allen, N. A. Thomas, and P. R. Paquin), 1991. "Technical Basis for Establishing Sediment Quality Criteria for Nonionic Organic Chemicals Using Equilibrium Partitioning," in Environmental Toxicology and Chemistry, No. 10, pp. 1541-1583. 
DOE (U.S. Department of Energy), 1994. Programmatic Environmental Impact Statement for the Uranium Mill Tailings Remedial Action Ground Water Project, draft, DOE/EIS-0198, April 1994, prepared by the U.S. Department of Energy, UMTRA Project Office, Albuquerque Operations Office, Albuquerque, New Mexico.

DOE (U.S. Department of Energy), 1992. Remedial Action Plan and Site Design for Stabilization of the Inactive Uranium Mill Tailings Site at Falls City, Texas, final, DOE/AL-050520.0000, UMTRA Project Office, Albuquerque Operations Office, Albuquerque, New Mexico.

DOE (U.S. Department of Energy), 1991. Environmental Assessment of Remedial Action at the Falls City Uranium Mill Tailings Site, Falls City, Texas, UMTRA-DOE/EA-0468, December 1991, prepared by the U.S. Department of Energy, UMTRA Project Office, Albuquerque Operations Office, Albuquerque, New Mexico.

Duckham, J. M., and H. A. Lee, 1976. "The Treatment of Refractory Anaemia of Chronic Rental Failure with Cobalt Chloride," in Quarterly Journal of Medicine, No. 45 (178), pp. 351-372.

Eargle, D. H., and A. D. Weeks, "Uranium-bearing Clays and Tuffs of South-Central Texas," in Field Excursion, Central Texas, October 1961, Texas University Bureau of Economic Geology Guidebook 3, 1961, pp. 19-30.

Eisler, R., 1989. Molybdenum Hazards to Fish, Wildlife, and Invertebrates: A Synoptic Review, prepared by the Patuxent Wildlife Research Center, U.S. Fish and Wildlife Service, Laurel, Maryland, for the U.S. Department of the Interior, Fish and Wildlife Service, Biological Report 85(1.19).

Eisler, R., 1988. Arsenic Hazards to Fish, Wildlife, and Invertebrates: A Synoptic Review, prepared by the Patuxent Wildlife Research Center, U.S. Fish and Wildlife Service, Laurel, Maryland, for the U.S. Department of the Interior, Fish and Wildlife Service, Biological Report 85(1.12).

Eisler, R., 1986. Chromium Hazards to Fish, Wildlife, and Invertebrates: A Synoptic Review, prepared by the Patuxent Wildlife Research Center, U.S. Fish and Wildlife Service, Laurel, Maryland, for the U.S. Department of the Interior, Fish and Wildlife Service, Biological Report 85(1.6).

Eisler, R., 1985a. Selenium Hazards to Fish, Wildlife, and Invertebrates: A Synoptic Review, prepared by the Patuxent Wildlife Research Center, U.S. Fish and Wildlife Service, Laurel, Maryland, for the U.S. Department of the Interior, Fish and Wildlife Service, Biological Report 85(1.5).

Eisler, R., 1985b. Cadmium Hazards to Fish, Wildlife, and Invertebrates: A Synoptic Review, prepared by the Patuxent Wildlife Research Center, U.S. Fish and Wildlife Service, Laurel, Maryland, for the U.S. Department of the Interior, Fish and Wildife Service, Biological Report 85(1.2). 
Elinder, C. G., 1986. "Iron," Handbook on the Toxicology of Metals, L. Friberg, G. F. Nordberg, and V. Vouk, eds., second edition, Elsevier Science Publishers, Amsterdam.

Elinder, C. G., 1985. Cadmium and Health: A Toxicological and Epidemiological Appraisal, Ch. 3, L. Friberg, C. G. Elinder, T. Kjellström, and G. F. Nordberg, eds., CRC Press, Boca Raton, Florida.

EPA (U.S. Environmental Protection Agency), 1994a. Integrated Risk Information System (IRIS), data base, Office of Research and Development, Washington, D.C.

EPA (U.S. Environmental Protection Agency), 1994b. "Health Effects Assessment Summary Tables (HEAST)," annual update, March 1994, 9200.6-303 (94-1), Office of Solid Waste and Emergency Response, Washington, D.C.

EPA (U.S. Environmental Protection Agency), 1992a. Drinking Water Criteria Document for Sulfate, final, Health and Environmental Criteria Division, Office of Science and Technology, U.S. Environmental Protection Agency.

EPA (U.S. Environmental Protection Agency), 1992b. "Developing a Work Scope for Ecological Assessments," in Eco Update, intermittent bulletin, Vol. 1, No. 4, U.S. Environmental Protection Agency, Office of Emergency and Remedial Response, Hazardous Site Evaluation Division, Washington, D. C.

EPA (U.S. Environmental Protection Agency), 1992c. "Toxic Substance Spreadsheet," Region IV, U.S. Environmental Protection Agency, Atlanta, Georgia.

EPA (U.S. Environmental Protection Agency), 1991. Human Health Evaluation Manual, supplemental guidance, "Standard Default Exposure Factors," U.S. Environmental Protection Agency, Washington, D.C.

EPA (U.S. Environmental Protection Agency), 1989a. Risk Assessment Guidance for Superfund, Volume I, Human Health Evaluation Manual, Part A, interim final, EPA/540/1-89/002, Office of Solid Waste, Waste Management Division, Washington, D.C.

EPA (U.S. Environmental Protection Agency), 1989b. Risk Assessment Guidance for Superfund, Volume II, Environmental Evaluation Manual, EPA/540/1-89/001, Office of Emergency and Remedial Response, Washington, D.C.

EPA (U.S. Environmental Protection Agency), 1989c. Drinking Water Criteria Document for Uranium, external review draft, Criteria and Standards Division, Office of Drinking Water, Washington, D.C.

EPA (U.S. Environmental Protection Agency), 1986. Quality Criteria for Water, EPA 440/5-86-001, Office of Regulations and Standards, Washington, D.C. 
EPA (U.S. Environmental Protection Agency), 1972. "Water Quality Criteria," National Academy of Sciences and National Academy of Engineering, Washington, D.C.

Fisenne et al. (I. M. Fisenne, P. M. Perry, and N. H. Harley), 1988. "Uranium in Humans," in Rad. Prot. Dosim., Vol. 24, pp. 127-131.

Flanagan, et al. (P. R. Flanagan, J. S. McLellan, J. Haist, M. G. Cheriah, M. J. Chamberlain, and L. S. Valberg), 1978. Gastroenterology, Vol. 74, pp. 841846.

Follett, R. H., and P. N. Soltanpour, 1985. "Irrigation Water Quality Criteria," Colorado State University Extension Service, publication number 506.

Friberg et al. (L. Friberg, G. F. Nordberg, and V. B. Vouk), 1986. Handbook on the Toxicology of Metals, Volume II: Specific Metals, second edition, Elsevier, New York, New York.

Gilman et al. (A. G. Gilman, L. S. Goodman, and A. Gilman), 1990. The Pharmacological Basis of Therapeutics, sixth edition, Macmillan Publishing Company, Inc., New York, New York.

Goyer, Robert A., 1991. "Toxic Effects of Metals," Toxicology: The Basic Science of Poisons, fourth edition, M. O. Amdur, J. Doull, and C.D. Klaassen, eds., Pergamon Press, New York, New York, pp. 623-680.

IARC (International Agency for Research on Cancer), 1987. IARC Monographs on the Evaluation of the Carcinogenic Risk of Chemicals to Humans, Supplement 7.

Johnston, M. C., 1963. "Past and Present Grasslands of Southern Texas and Northeastern Mexico," in Ecology, Vol. 44, No. 3, pp. 456-466.

Josephs, H. W., 1958. "Absorption of Iron as a Problem in Human Physiology," in Blood, No. 13 , pp. 1-54.

Kenaga, E. E., 1980. "Predicted Bioconcentration Factors and Soil Sorption Coefficients of Pesticides and Other Chemicals," Ecotoxicology and Environmental Safety, No. 4, pp. 26-38.

Kjellström, T., 1979. Environmental Health Perspective, Vol. 28, pp. 169-197.

Leach et al. (L. J. Leach, R. M. Gelein, B. J. Panner, C. L. Ylie, and C. C. Cox), 1984. The Acute Toxicity of the Hydrolysis Products of Uranium Hexafluoride (UF6) When Inhaled by the Rat and Guinea Pig, final report, ISS K/SUB-81-9039-3, NTIS DE84011539. 
Maheshwari et al. (U. R. Maheshwari, J. T. McDonald, V. S. Schneider, A. J. Brunetti, L. L. Leybin, E. Newbrun, and H. C. Hodge), 1981. "Fluoride Balance Studies in Ambulatory Health Men With and Without Fluoride Supplements," in American Journal of Clinical Nutrition, December 1981, Vol. 34, pp. 2679-2684.

Maynard, E. A., and H. C. Hodge, 1949. "Study of Toxicity of Various Uranium Compounds When Fed to Experimental Animals," Pharmacology and Toxicology of Uranium Compounds, National Nuclear Energy Services, Div. VI, Vol. 1, C. Voegtlin and H. C. Hodge, eds., McGraw Hill, New York, New York, pp. 309-376.

McCulloh, R. P., and C. Roberts, 1981. "Geology of the Nuhn Uranium Ore Body," Jackson Group, South Texas Uranium District, South Texas Geological Society Bulletin, Vol. 24, pp. 23-46.

McMahan et al. (C. A. McMahan, R. G. Frye, and K. L. Brown), 1984. "The Vegetation Types of Texas Including Cropland," Texas Parks and Wildlife Department, Austin, Texas.

National Research Council, 1989. Recommended Daily Allowances, tenth edition, National Academy Press, Washington, D.C.

National Research Council, 1980. Drinking Water and Health, Volume 3, Safe Drinking Water Committee.

National Research Council, 1971. Nutrient Requirements of Dairy Cattle, Committee on Animal Nutrition, fourth edition, The National Academy of Science, Washington, D.C.

NCRP (National Council on Radiation Protection and Measurements), 1984. Exposure From the Uranium Series With Emphasis on Radon and Its Daughters, NCRP Report 77, Bethesda, Maryland.

NOAA (National Oceanic and Atmospheric Administration), 1990. "The Potential for Biological Effects of Sediment-Sorbed Contaminants Tested in the National Status and Trends Program," NOAA technical memo, NOS OMA 52.

Nordberg et al. (G. F. Nordberg, T. Kjellström, and M. Nordberg), 1985. Cadmium and Health, a Toxicological and Epidemiological Appraisal, Ch. 6, L. Friberg, C. G. Elinder, T. Kjellström, and G. F. Nordberg, eds., CRC Press, Boca Raton, Florida.

NUREG (Nuclear Regulatory Agency), 1986. Update of Part 61, Impacts Analysis Methodology, NUREG/CR-4370, Vol. 1, Division of Waste Management, Office of Nuclear Material Safety and Safeguards.

PNL (Pacific Northwest Laboratory), 1989. "Sorption Distribution Coefficient Data," Multimedia Environmental Pollutant Assessment System, Pacific Northwest Laboratory, Richland, Washington. 
Prister, B. S., 1969. GKIAE Report by Atomizdat, Moscow (Canadian translation AEC/TR/7178 [1970] and USCEAR Rep. A/AC.82/G/L 1298).

Raun, G. G., and F. R. Gehlbach, 1972. "Amphibians and Reptiles in Texas, Taxonomic Synopsis, Bibliography, County Distribution Maps," in Dallas Museum of National History, Bulletin 2, Dallas, Texas.

Rose, F. L., and F. W. Judd, 1982. "Biology and Status of Berlandier's Tortoise (Gopherus berlandieri," in North American Tortoises: Conservation and Ecology, U.S. Fish and Wildlife Service, Research Report 12, Washington, D.C.

Schafer, G. W., 1937. Records of wells, drillers' logs, and water analyses and map showing locations of wells in Karnes County, Texas, Texas Board of Water Engineers, duplicated report, $73 \mathrm{p}$.

Shea, D., 1988. "Developing National Sediment Quality Criteria," in Environmental and Scientific Technology, No. 22(11), pp. 1256-1261.

Smith, W. 1993. Falls City city hall, personal communication with Malu GawthropCooper, Jacobs Engineering Group Inc., UPDCC File Location No. 0.2.8, October 4, 1993.

Stevens et al. (W. F. Stevens, W. Bruenger, D. R. Atherton, J. M. Smith, and G. N. Taylor), 1980. "The Distribution and Retention of Hexavalent ${ }^{233} \mathrm{U}$ in the Beagle," in Radiat. Res., Vol. 83, pp. 109-126.

Strecker, J. K., and J. E. Johnson, 1935. "Notes on the Herpetology of Wilson County, Texas," in Baylor University Bulletin, Vol. 38, No. 3, pp. 17-23.

Sullivan et al. (M. F. Sullivan, P. S. Ruemmler, J. L. Ryan, and R. L. Bushhom), 1986. "Influence of Oxidizing or Reducing Agents on Gastrointestinal Absorption of $U$, Pu, Am, Cm, and Pm by Rats," in Health Physics, Vol. 50, pp. 223-232.

Summerskill, W. H. J., and E. Wolpert, 1970. "Ammonia Metabolism in the Gut," in American Journal of Clinical Nutrition, Vol. 23, pp. 633-639.

Swingle, H. S., 1969. Methods of Analysis for Waters, Organic Matter, and Pond Bottom Soils Used in Fisheries Research, Auburn University, Auburn, Alabama, 119 pp.

TAC (Technical Assistance Contractor), 1994. "Water Use Survey Near Falls City Site," JEGE/JEG/0994-0294, prepared by the TAC, Jacobs Engineering Group Inc., for the U.S. Department of Energy, UMTRA Project Office, Albuquerque Operations Office, UPDCC File Location No. 20.19.2.7, Albuquerque, New Mexico, January 1994. 
TAC (Technical Assistance Contractor), 1990a. "Unpublished Field Notes, Falls City, Texas, Uranium Mill Tailings Site," prepared by the TAC, Albuquerque, New Mexico, for the U.S. Department of Energy, UMTRA Project Office, Albuquerque Operations Office, Albuquerque, New Mexico.

TAC (Technical Assistance Contractor), 1990b. Falls City Radon Monitoring:

Pre-Remedial Action Summary, prepared by the TAC, Albuquerque, New Mexico, for the U.S. Department of Energy, UMTRA Project Office, Albuquerque Operations Office, Albuquerque, New Mexico.

Tennant, A., 1984. The Snakes of Texas, Texas Monthly Press, Austin, Texas.

Texas Colonial Waterbird Society, 1982. "An Atlas and Census of Texas Waterbird Colonies 1973-1980," Caesar Kleberg Wildlife Research Institute, Texas A and I University, Kingsville, Texas.

Thompson et al. (W. E. Thompson, W. V. Swarzenski, D. L. Warner, G. E. Rouse, O. F. Carrington, R. Z. Pyrih), 1978. Groundwater Elements of in Situ Leach Mining of Uranium, NUREG/CR-0311, prepared by Geraghty \& Miller, Inc. for the U.S. Nuclear Regulatory Commission, Silver Springs, Maryland.

Tracy et al. (B. L. Tracy, J. M. Quinn, J. Lahey, A. P. Gilman, K. Mancuso, A. P. Yagdinas, and D. C. Villeneuve), 1992. "Absorption and Retention of Uranium From Drinking Water by Rats and Rabbits," in Health Physics, Vol. 62, pp. 65-73.

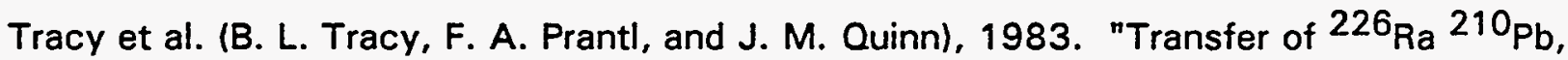
and Uranium from Soil to Garden Produce: Assessment of Risk, " in Health Physics, Vol. 44, p. 469.

TWC (Texas Water Code), Chapter 307, Texas Surface Water Quality Standards, Section 307.6, "Toxic Materials."

TWC (Texas Water Code), Chapter 52, Underground Water Conservation Districts, Subchapter A, "General Provisions," Section 52.005, "Applicability to Underground Water Conservation Districts Generally."

TWC (Texas Water Code), Chapter 52, Underground Water Conservation Districts, Subchapter B, "Creation of Districts and Management Areas Generally," Section 52.021, "Purpose."

TWC (Texas Water Code), Chapter 28, Water Quality Control, Subchapter B, "Water Wells," Section 28.011, "Underground Water: Regulations."

TWC (Texas Water Code), Chapter 26, Water Quality Control, Subchapter A, "Administrative Provisions," Section 26.023, "Water Quality Standards."

TWC (Texas Water Code), Chapter 11, Water Rights Law, Section 11.023, "Purposes for Which Water May be Appropriated." 
TWC (Texas Water Code), Chapter 5, Texas Water Commission, Subchapter A, "General Provisions," Section 5.120, "Conservation and Quality of Environment."

TWC (Texas Water Code), Chapter 5, Texas Water Commission, Subchapter A, "General Provisions," Section 5.013, "General Jurisdiction of Commission."

Weigel, F., 1983. "Uranium and Uranium Compounds," Kirk-Othmer Encyclopedia of Chemical Technology, third edition, M. Grayson, ed., John Wiley and Sons, New York, New York, Vol. 23, pp. 502-547.

Whitney et al. (E. N. Whitney, E. N. Hamilton, and S. R. Rolfes), 1990. Understanding Nutrition, fifth edition, West Publishing Co., St. Paul, Minnesota.

Wrenn et al. (M. E. Wrenn, P. W. Durbin, B. Howard, J. Lipsztein, J. Rundo, E. T. Still, and D. L. Willis), 1985. "Metabolism of Ingested $U$ and $R a, "$ in Health Physics, Vol. 48, pp. 601-633.

\section{FEDERAL REGISTER}

52 FR 36000, Standards for Remedial Actions at Inactive Uranium Processing Sites: Proposed Rule, September 24, 1987.

\section{UNITED STATES CODE}

42 USC $\$ 7901$ et seq., Uranium Mill Tailings Radiation Control Act of 1978, November 8, 1978. 